\title{
DigitalCommons@NYLS
}

Articles \& Chapters

Faculty Scholarship

2009

A Fair Price and a Fair Deal: On the Future of 'Entire Fairness' in Freezeouts

Faith Stevelman

Follow this and additional works at: https://digitalcommons.nyls.edu/fac_articles_chapters

Part of the Banking and Finance Law Commons, and the Business Organizations Law Commons 
New York Law School Legal Studies

Research Paper Series 09/10 \#3

\section{A Fair Price and A Fair Deal: On the Future of "Entire Fairness" in Freezeouts}

By: Faith Stevelman

Professor, New York Law School

(http:IIw Inyls.edu/fstevelman)

This paper can be downloaded free of charge from the Social Science Research Network at: http://ssrn.com/abstract= 1431992

New York Law School's website can be accessed at www.nyls.edu 


\title{
A FAir Price AND A FAIR DEAL: ON “ENTIRE FAIRnESS” in FrEEZEOUTS
}

[This Article is a revised and updated version of one published earlier by the author as: "Going Private at the Intersection of the Market and the Law,” 62 Bus. Law. 775 (2007)]

\section{Faith Stevelman [a1]}

fstevelman@nyls.edu

\begin{abstract}
Controlling shareholders can compel the sale of minorities' shares in freezeouts, potentially to their financial detriment. To limit controllers' opportunism and support the value of minorities' investments, the Delaware supreme court has endorsed strong minority shareholder protections under the rubric of "Entire Fairness" - the governing standard for cash-out mergers. However, the court of chancery has refused to apply Entire Fairness to tender offer freezeouts, and is advocating unifying freezeout doctrine around a looser, deferential standard of review. The influence of popular and Congressional concern over excess plaintiff lawyers' fees and discovery costs is likely making itself felt, although the true extent of these litigation agency costs is unknown and likely overstated. This influence is evident in three recent court of chancery cases analyzed herein (Pure, Cysive and Cox), which advocate lesser scrutiny of controllers' transactions. There are several problems with the court of chancery's proposed reforms, including that they conflict with Delaware supreme court precedent. A fair price duty is crucial to minorities' bargaining leverage with controllers, and controllers' power financially to oppress minorities if their freezeouts are thwarted ("inherent coercion") remains a genuine concern for equity. Lack of minority consent is still a problem that equity should be responsive to. This Article presents the case for applying Entire Fairness review to cash-out mergers and tender offer freezeouts. The sole exception should be when a controller authorized an independent committee to conduct an auction or market check and agreed to sell if a substantially higher offer for the company surfaced.
\end{abstract}

\section{TABLE OF CONTENTS}

Introduction

Foundations of the Doctrines Governing Freezeouts

A. The Entire Fairness Standard for Cash-Out Mergers $\quad 7$ Weinberger $v$. UOP

B. Always Entire Fairness, But A Burden Shift with Approval: 10 Kahn v. Lynch

C. In Contrast: The Legal Background to Tender Offer Freezeouts 11

D. Freezeout Litigation Reform and Contemporary Public Policy 14 
$\begin{array}{lr}\text { II. Fair Price: Inconsistent Legal Approaches } & 16\end{array}$

A. Tender Offer Freezeouts: No Legal Standard for Price 17

B. Appraisal's “Fair Value” Standard (and Cash-Out Mergers) 18

C. "Fair Price" and Equitable Actions against Cash-Out Mergers 20

D. The Need for A Uniform Legal Price Rule for Freezeouts 22

III. In Flux: Controllers' Duties in Tender Offer Freezeouts 23

A. Background to the Recent Tender Offer Freezeout Cases 23

1.The Solomon Decision 24

2. The Glassman Decision 26

B. Siliconix: Delaware's First Tender Offer Freezeout Decision 28

1. Siliconix's Facts 28

2. Coercion and Inadequate Disclosure by Controllers 30

3. Directors' Duties in Tender Offer Freezeouts 31

C. Pure Resources: New Preconditions For Deferential Review 32

1. The Facts in Pure 32

2. Doctrinal Analysis and Pure's Holding 35

3. Closer Analysis of Pure's New Requirements 38

D. The Cox Decision Adds Another Special Committee Requirement 40

E. Contemporary Tender Offer Freezeout Doctrine, In Summary 41

IV. Scrutinizing the Effect of Entire Fairness in Freezeouts 42

A. Cysive Derides Entire Fairness Review 42

1. The Facts in Cysive 42

2. Litigating Factually-Intensive Questions in Equity 43

3. The Importance of the Burden of Proof in Freezeout Suits 44

4. Entire Fairness and Motions to Dismiss 45

B. The Cox Decision as an Advisory Opinion 46

1. The Cash-Out Merger in Cox 46

2. A Plan for Comprehensive Doctrinal Reform for Freezeouts 47

C. Cox's Criticisms of the Entire Fairness Standard for Freezeouts 49

1. Motions to Dismiss Under the Lynch Doctrine, Again 49

a. Are Claims under Entire Fairness Nondismissable? 49

b. Entire Fairness and "Mere" Valuation Disputes 50

c. How Controllers Benefits from Early Settlements 50

d. Dismissals under Revlon versus Lynch 51

2. Attorneys' Fees in Settlements Under the Lynch Doctrine 52

3. Litigation Commenced During Freezeout Negotiations 53

4. The Utility of Discovery 54

5. Suits Against Target Directors During Negotiations 55

D. Reducing Litigation in Freezeouts 56

1. The Purported Problem and a Plan 56

2. Will the Quality of Consents Be Reviewable? 57

3. The Likelihood of Increased Appraisals

4. More Claims Against Target Directors? 58

5. Will Minorities' Approvals Be Used to Exculpate Directors? 58 
6. The Evolution of Transactional Choreography for Freezeouts 59

V. After Cox: Bargaining in the Shadow of a Limited Fair Price Duty? 59

A. The Fair Price Duty and Negotiations 60

B. Cox on the Fair Price Question 62

C. Empirical Evidence 63

VI. Fair Dealings and the Consent Question 64

A. The Substance of Fair Dealings 64

B. Property Law Concerns 64

C. Institutional Checks and Balances in Corporate Governance 65

D. Voluntary Consent and Legal Theory 66

VII. Inherent Coercion: The 800 Pound Gorilla That Won’t Go Away 68

A. Independent Directors' Capacity to Say "No" Now? 68

B. Institutional Investors' Capacity to Say "No" Now? 69

C Cox's Use of Rhetoric to Discredit Inherent Coercion 70

1. Parody -- Funny But Disturbing 71

2. Inherent Coercion -- A “Sociological Inference” 73

3. A Pointed Rhetorical Question 73

4. Corporate Law -- A Species of Commercial Law? 73

5. Creating Urgency Through Hyperbole $\quad 74$

VIII. Proposals: Twenty-First Century Standards for Freezeouts 74

A. A Unified Doctrine for Freezeouts 75

B. Entire Fairness as the Standard for Freezeouts 75

C. The Lynch Doctrine is Not "Broken” 76

D. Auctions and Market Checks 77

E. Burdens of Proof and Burden Shifting Going Forward 78 


\section{INTRODUCTION}

This Article analyzes the legal doctrines governing "freezeouts," which are a form of going private transaction. [1] In a freezeout the person or entity that has the status of a controlling shareholder [2] at a company purchases its remaining publicly-traded shares. [3] The exiting minority shareholders usually receive cash for their shares, which terminates their financial interest in the corporation. The stakes for minorities are thus quite high. As for the controller, once the company becomes wholly owned, it may be kept as a privately held entity, merged into another business entity owned by the controller, or sold to a third party.

Controllers stand to make substantial profits from purchasing minorities' shares in freezeouts.[4] The harder question is whether minorities do passably well-- and even what passably well should mean. When minorities present claims of unfairness in future freezeout suits, the fundamental legal question will be whether the courts will employ the heightened fiduciary standards of fair dealings and fair price developed under the rubric of "Entire Fairness" to ensure that controllers are not profiting to the detriment of minorities in these transactions. In contrast to the direction signaled in a triad of high profile decisions by the Delaware court of chancery, [5] this Article contends that the "Entire Fairness" [6] standard should govern in all fiduciary freezeout claims against controllers, with one important exception. [7]

As a matter of legal structure, freezeouts occur most commonly through cash-out mergers [8] or tender offers combined with short form mergers (a "tender offer freezeout"). [9] The structural features of freezeouts are straightforward. Indeed, in both instances, the background, statutory requirements do not differentiate between controllers and third party acquirers. What makes freezeouts distinctive, and highly significant for corporate fiduciary law, is that controllers' formal and informal authority over the target's board, in combination with their other power advantages, in essence allows them to operate at both sides of the freezeout. That is, while controllers are buyers in freezeouts, they can also influence the sell side of the deal in their private interest -- to the minority's detriment, potentially. Such self-dealing is at the crux of corporate fiduciary law, and hence so is the standard to be applied to freezeouts.

Under Delaware fiduciary law at present, controllers can block the controlled company's directors from initiating an auction to sell the company, and from pursuing other financial or transactional alternatives more consistent with the minorities' best interests. [10] Controllers' dominating influence over the board is complemented by their direct legal power to vote in their self interest - hence to block many other transactions which might be beneficial to minorities.[11] The result is that controllers can pressure minorities to sell in a freezeout through the omnipresent if implicit threat that they could be made worse off by the controller if they opposed its offer. Courts have named this concept "inherent coercion." [12] Inherent coercion operates in freezeouts based on tender offers as well as those based on cash-out mergers. Both formats present substantial dangers of coercion and overreaching by controllers-as-insiders. [13]

As a general matter, corporate law affords controllers discretion to vote and sell their shares in their self-interest.[14] However, once a controller's authority to inhibit the board's impartiality 
is relevant in a corporate transaction, the courts apply heightened fiduciary standards to the controller's conduct. [15] Most significantly for this Article, the Delaware supreme court has judged controllers' opportunity for self-dealing in cash-out mergers as being so substantial that it has mandated that without exception courts should apply the Entire Fairness standard to minorities' claims of unfairness in these transactions. (This steadfast adherence to the Entire Fairness standard in cash-out merger freezeouts is referred to herein as the "Lynch Doctrine.”) [16]

Because the Entire Fairness Standard, like other fiduciary standards, is inherently openended, [17] and because freezeouts involve complex valuation disputes, [18] their adjudication requires courts to address fundamental questions in corporate law. Most especially, Delaware's equity courts must balance their historic obligation to protect vulnerable parties -- minority shareholders in freezeouts -- against the goal of facilitating wealth producing corporate transactions. [19] The quality of the fiduciary doctrine governing freezeouts is especially important because it is principally state corporate fiduciary law, [20] rather than state statutory or federal law, [21] that defines the scope of controllers' rights and duties and minorities' entitlements in freezeouts. And Delaware's freezeout doctrine is preeminently important because a majority of the largest U.S. public companies are incorporated in Delaware, [22] and also because many states model their corporate laws on Delaware's. [23]

Nevertheless, Delaware's freezeout doctrine is presently in disarray. Courts apply the exacting Entire Fairness standard to controllers' cash-out mergers, consistent with Weinberger $v$. UOP, Inc. [24] ("Weinberger”) and Kahn v. Lynch Communications Systems, Inc. [25] ("Lynch”) landmark decisions from the Delaware supreme court. (The latter is the progenitor of the Lynch Doctrine.) However, based on an arguably over-broad reading of the supreme court's decisions in Solomon v. Pathe Communications Corp. ("Solomon") [26] and Glassman v. Unocal Exploration Corp. (“Glassman”)[27], the court of chancery has not applied fair dealings or fair price requirements to tender offer freezeouts.[28] Moreover, this doctrinal disjunction has arisen without the Delaware supreme court's ever thoroughly considering the matter.[29]

This is ambiguity is harmful for Delaware fiduciary law, and for capital market efficiency. But in the near term, controllers may profit from the market failure likely to arise from such doctrinal irregularities. To clarify, controllers (rather than target boards or minority shareholders) initiate freezeouts and hence dictate their formal structure. Furthermore, controllers have broad leeway rapidly to alter and hence arbitrage transactional structures, and their attendant legal rules and constraints, in their self interest (indeed, even after the freezeout has commenced). Given this discretionary authority, the complexity of freezeout doctrine, and controllers' incentives, it's likely that controllers are gaming a substantial degree of market failure to profit in freezeouts. In this respect, the perpetuation of different equitable standards for freezeouts, including disparate legal price criteria, is undermining minorities' welfare and increasing the cost of public equity capital.[30]

The Delaware courts have become increasingly sensitive to the current disarray in freezeout doctrine and its ill effects. In a recent trio of cases the court of chancery has proposed sweeping reform. [31] These cases are In re Pure Resources, Inc. ("Pure”), [32] In re Cysive Inc.("Cysive”), 
[33] and In re Cox Communications Inc. Shareholders Litigation (“Cox"). [34] In Pure, Cysive and Cox the court has proposed unifying freezeout doctrine -- a proposal also endorsed by this Article. However, the court has proposed that the controller-friendly, deferential, "business judgment rule” [35] standard should apply to both freezeout formats, unless either the directors or a majority of the minority shares has rejected the controller's offer. (The application of deferential, business judgment review to freezeouts where there's been such "Dual Ratification" is referred to herein as the "Cox Reforms.") [36]

The Cox opinion proposes that a freezeout's receipt of Dual Ratification constitutes adequate evidence of its fairness. [37] So long as there's been Dual Ratification, the court of chancery has opined in Cox, strict scrutiny of the freezeout for fairness is wasteful for the litigants and invites abuse by plaintiff lawyers. [38] A further, unstated assumption in the Cox opinion is that controllers will obtain Dual Ratification most of the time. Were this not so, the Cox Reforms would not achieve their expressly intended effect: reducing litigation and encouraging freezeouts. Hence, if the Cox Reforms are followed, freezeouts will be subject to less vigorous and less frequent judicial review.[39] Consistent with Cox's express objectives, most shareholder claims would be dismissed on the pleadings. [40]

This Article devotes careful attention to the reasoning in Pure, Cysive, and Cox because they represent a watershed in the court of chancery's analysis of freezeout doctrine. They are likely to have a profound influence on minorities' welfare in future freezeouts, and shape future courts' adherence to the Entire Fairness standard. [41] The Cox opinion contends that allowing deferential review in freezeouts that receive Dual Ratification will more squarely situate freezeout doctrine within the core framework of Delaware fiduciary law. [42] The court of chancery has also represented that the proposed reforms will reduce meritless litigation, [43] benefit minority investors, [44] and strengthen the capital markets. [45] But many of these positive claims are exaggerated, as are the criticisms of applying Entire Fairness to freezeouts, as described below.

Returning to doctrinal specifics: the transactional choreography applied to cash-out mergers and to tender offer freezeouts represents different judicial responses to three related legal questions. These are (i) whether controllers have a legal duty to pay at least a minimum "fair price” for the minorities' shares in a freezeout, (ii) whether public stockholders have adequate freedom and ability to reject and defeat an unfair freezeout offer, and (iii) whether target directors are unduly constrained in their ability to act in minorities' interests in freezeouts. At present, Delaware's freezeout doctrine endorses unduly disparate answers to these questions based on the formalistic structure of the freezeout. Nevertheless, for both forms of freezeouts, the doctrine allows that if a controller has adhered to the court's view of best practices ("transactional choreography"), then it will receive more favorable judicial treatment if the transaction proceeds and is contested. This promise of comparatively more favorable (i.e. lenient) treatment in litigation provides the incentive for controllers to adhere to the transactional "steps" prescribed by the courts.

To recap, as the Delaware chancery court has read the Solomon and Glassman decisions, in tender offer freezeouts so long as controllers refrain from egregious coercion or deception of the 
minority shareholders, the freezeout transaction will be reviewable under the deferential business judgment rule standard. [69] To the contrary, in doctrine evolving from Weinberger and Kahn $v$. Lynch, the courts apply strict scrutiny, allowing controllers at most a beneficial shift in the burden of proof if the freezeout has been approved either by disinterested directors or a majority of the minority of shares. [70] Such ratification produces merely a shift in the burden of proof, however (so that notwithstanding the self-interested nature of the transaction, the plaintiffs must prove its unfairness). [71] This favorable burden shift is the maximum benefit controllers can obtain from such approvals under the "Lynch Doctrine;" the Entire Fairness standard will apply in any event. [72]

This Article recommends unifying freezeout doctrine under the Entire Fairness standard. Entire Fairness should apply unless the controller has allowed the minority's representatives to conduct an auction or market check, and the controller has agreed to sell its block if its bid is substantially bettered by a third party. [73] If a controller proceeds without following this new transactional choreography, it should face the Entire Fairness standard if the transaction is litigated.[74] Where controllers are unwilling or unable to comply with this condition, there is only a simulacrum of real bargaining and no basis to presume the fairness of the freezeout.[75]

Part I of this Article reviews the doctrinal framework for cash-out mergers established by Weinberger [76] and Lynch, [77] and then contrasts this with the doctrinal framework for tender offer freezeouts which has developed from Solomon [78] and Glassman. [79] Part II critiques the three disparate legal price regimes that are relevant to freezeouts, elucidating how controllers can arbitrage their differences in their self interest. [80] Part III digs deeper into contemporary tender offer freezeout doctrine, and especially the recent alterations to tender offer freezeout doctrine proposed by the court of chancery in Pure[81] and Cox. [82] Part IV debunks the court of chancery's harsh criticisms of Entire Fairness review in freezeouts, as presented in Cysive [83] and Cox. Parts V and VI, respectively, are devoted to analyzing the importance of fair price and fair dealings for minorities, while Part VII contends that inherent coercion has neither been disproven nor minimized as a threat to minorities' welfare. Part VIII details the Article's law reform proposals.

\section{FOUNDATIONS OF THE DOCTRINES GOVERNING FREEZEOUTS}

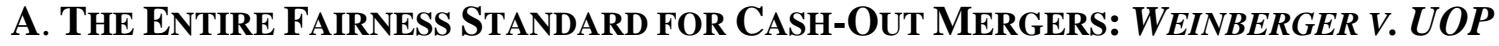

The Delaware General Corporation Law ("DGCL”) requires approval by a majority of a company's directors and a majority of its outstanding voting shares as a condition to a company's sale via a merger. [84] Because the controller owns the shares required to determine the outcome of director elections, [85] the minority shareholders' voting power cannot stop a controller intent on a cash-out merger. Voting power over the board might also influence board decisions on the declaration (or nondeclaration) of dividends. More directly, a controller's stock ownership affords it power to effect amendments to the bylaws, [86] approvals (or disapprovals) of sales of substantially all assets, [87] and amendments to certificates of incorporation. [88] Hence, when a controller presents a freezeout proposal, its power to compel the transaction, or take action 
injurious to the minority if it fails, is quite apparent to the target board and minority shareholders.

It's the controller's power over the target's board that places freezeouts in the infamous category of self-dealing transactions. If a controlled company's board could operate with genuine independence from the controller, then the controller would only be on the "purchase" side of the transaction. The heightened fiduciary protections that courts apply to self-dealing transactions under the duty of loyalty would be unwarranted. Corporate law provides that directors owe fiduciary duties of care and loyalty to all shareholders equally, not just those who elect them. [89] But once a controller is present, the directors are in a compromised, fundamentally conflicted situation. If they act in ways that conflict with the controller's plans, their tenure on the board will likely be limited. Finally, because boards are only composed of human beings, and human beings tend to avoid professional confrontations unless they have something concrete and substantial to gain, most boards will have a bias in favor of approving a controller's offer. [90]

Controllers' freedom to use cash-out mergers to force minority shareholders out of their investment has been a persistently controversial question in corporate law. [91] In the late 1970s the Delaware courts required a "business purpose" for cash-out mergers, in order to limit controllers' opportunity to use them to expropriate wealth from minorities. [92] However in Weinberger, in 1983, the Delaware supreme court rejected the business purpose requirement as too indeterminate to protect minorities from overbearing controllers.[93] The court endorsed the Entire Fairness standard as the better approach to protecting minorities. Specifically, in Weinberger the court held that duties of "fair price" and "fair dealings"-- hence, "Entire Fairness”-- apply to controllers' cash-out mergers.[94]

With respect to fair price, in Weinberger the court held that controllers have a fiduciary duty to pay minorities at least their pro rata share of the company valued as a going concern (as discussed further in Part II). [95] And because fair price is range rather than a finite sum, Weinberger requires that controllers be accountable, also, for the fairness of the process through which they acquire the minority's shares in the cash-out merger -- i.e., "fair dealings" on their part. [96] Weinberger's fair dealings requirement encompasses factors relating to how the transaction is initiated, structured, and timed by the controller. [97] Despite the controller's statutory authority to compel a cash-out merger, Weinberger exhorted controllers to allow some qualified, independent party to negotiate the transaction's key terms on the minority's behalf. The court espouses the goal that the controller and minority's representatives should be able to bargain as if at "arms' length." [98] Accordingly, as part of fair dealings, in Weinberger the court emphasized controllers' fiduciary disclosure duty, as relevant to the shareholders' decision making regarding the merger or seeking an appraisal. [99]

Beyond providing a benchmark for liability ex post, Weinberger's fair price and fair dealing standards have proven enormously influential in shaping controllers' tactics in planning and negotiating cash-out mergers. [100] As mentioned above, the Weinberger opinion has encouraged controllers to establish special committees of independent directors to negotiate for the minority shareholders. [101] In so doing Weinberger established what is still the formative transactional choreography for cash-out mergers. [102] Weinberger also encouraged what is now the accepted 
practice of having outside, independent financial and legal experts advise special committees during the negotiations. [103] And Weinberger's emphasis on full disclosure has encouraged controllers to disclose information about the timing, structure, motive and pricing of their offer, independent of formal, securities law mandates.[104]

As mentioned above, controllers' freedom to eliminate minorities through cash-out mergers has at times proven highly controversial. [105] This "unsettledness" is evident in the recent Pure, Cysive and Cox opinions, as it was previously in the 1970's, and even earlier.[106] This controversy has sometimes flared into the public eye. During the bear market of 1973-74 for example, controversy arose over the losses suffered by minority shareholders in freezeouts, and the issue achieved national attention. In a speech at the University of Notre Dame, SEC Commissioner A. A. Sommer denounced controllers' freezeouts as "serious, unfair, sometimes disgraceful, a perversion of the whole process of public financing and a course that inevitably is going to make the individual shareholder even more hostile to American corporate mores and the securities markets than he already is.” [107]

After announcing a public investigation, in 1975 the SEC proposed two rules to protect minorities' interests in these deals. In contrast to federal securities regulation's usual disclosure oriented approach, both proposed SEC rules encompassed substantive fairness standards for freezeouts. Proposed SEC Rule 13e-3A provided that a controller's offer must "constitute fair value as determined in good faith by the issuer ... and shall be no lower than the consideration recommended jointly by two qualified independent persons." [108] Beyond requiring that the offered consideration must be "fair," proposed SEC Rule 13e-3B provided that controllers' cashout mergers must be motivated by "a valid business purpose.” [109] The proposed SEC rules also required that the company's counsel must opine that the cash-out merger met the applicable state fiduciary fairness criteria. [110] In sum, in the mid 1970s, the SEC was on the verge of imposing regulatory requirements which would virtually have shut freezeouts.

While the SEC was considering these rules, the overall shape of corporate federalism hung in the balance. Lawyers attending an ABA meeting on federal securities regulation in the summer of 1975 discussed a Yale Law Journal article published a year earlier by Professor William Cary. [111] Cary's article decried Delaware's excessively permissive approach to corporate law, and called for federal minimum standards to protect vulnerable public investors from abuse by corporate insiders. [112] Cary's claims are so famous that virtually all corporate legal academics are familiar with them. However, few seem to recall that Cary's critique coincided with and reflected widespread and fervent disapproval of going private transactions, and especially Delaware's lax response to them.

Most significantly for this discussion, no recollection of this tumult, or the near preemption of state fiduciary standards by federal regulations is reflected in the chancery court's recent freezeout cases.[113] But the history of the SEC's near preemption of fiduciary standards for freezeouts is significant. [114] First, it highlights that both the popular and legal acceptance of freezeouts is recent. Second, it reinforces that excessively lenient state corporate legal standards invite federal intervention which will not uncommonly be more heavy-handed. Viewing 
freezeout regulation in this historical perspective, it is harder to presume that looser fiduciary safeguards are best - either for investors or state corporate law. [115]

In the end, the movement to federalize freezeout regulation was truncated. In its final going private rule, Rule 13e-3, [116] the SEC backed away from its proposed substantive fairness standards for freezeouts. Instead, the Commission hewed to its traditional disclosure-oriented approach. The SEC may have been influenced to do so by the U.S. Supreme Court's 1977 decision in Santa Fe v. Green, which broadly reoriented federal securities law away from the substantive regulation of internal corporate affairs. [117] Also, by 1977 the need for a federal "business purpose" requirement had been obviated by the Delaware courts' own affirmation of a business purpose requirement for cash-out mergers.[118]

The movement to federalize freezeout regulation had been shut down before Weinberger was decided in 1983. But even after the Delaware supreme court's decision, many crucially important questions about freezeout doctrine remained unresolved. Most notably for this discussion, in the early 1990s, a split developed in the court of chancery over whether approval of a cash-out merger by the controlled entity's independent directors was sufficient indicia of fairness to allow business judgment rule review.[119] Weinberger had contradicted this position, in dicta; but apparently not expressly or forcefully enough to preclude subsequent controversy. [120]

\section{B. Always Entire Fairness, but a Burden Shift With Approval: KaHN V. LynCH}

In 1994, in its decision in Lynch (Kahn v. Lynch Communications, Inc.), the Delaware supreme court definitively addressed the effect of disinterested consent on the standard of review in cash-out mergers. Lynch held that the coercive authority of controllers taints the reliability of consents in cash-out mergers even when they appear freely given. On this basis Lynch held that disinterested, informed consents by directors or minority shareholders must be regarded merely as indicia of fairness - warranting only a shifting the burden of proof in controllers' favor. Deferential review under the business judgment rule standard is never appropriate in this setting, the court held. [121]

As stated earlier, the logic behind the inherent coercion notion is that independent directors and minority shareholders will rationally fear that the controller might take financial retribution against the minority if the offer is rejected. [122]). Consequently, their consent cannot be presumed freely given. In reaching this conclusion, Lynch validated sentiments earlier affirmed in Weinberger [123] and Rosenblatt v. Getty Oil Co. [124] And the court rejected the court of chancery precedents which allowed deferential review in controllers' cash-out mergers[125] (as well as ones allowing deferential review in self dealing transactions where no controller was present). [126] In Lynch the supreme court aligned itself with the court of chancery's opinion in Citron v. E.I. Du Pont de Nemours \& Co. [127] which had elucidated the operation of inherent coercion. In this manner Lynch has become the authoritative, landmark case affirming the appropriate judicial caution where controllers might otherwise benefit from inherent coercion.

Nevertheless, in Lynch the supreme court was sensitive to encouraging such informed, 
independent consents as a therapeutic measure in the minorities' interest. To encourage the practice, in Lynch the court provided that controllers would obtain a beneficial shift in the burden of proof where such informed, independent consent had been obtained (as mentioned above). [128] Based on Lynch's teachings, where a court rules that the consents are valid (informed, uncoerced and sufficiently numerous), the plaintiffs will have the burden to demonstrate the unfairness of the freezeout, instead of the controller having the burden to demonstrate fair price and fair dealings. (Ordinarily in Delaware fiduciary law, once self-dealing by a fiduciary is shown, the fiduciary must prove the inherent fairness of the transaction.) [129] It is this unwaivering skepticism of voluntary consent in freezeouts, and related insistence on strict scrutiny for fairness, that is the target of the court of chancery's ire in the recent cases.

\section{In Contrast: The Legal BACKground to Tender OfFER FreEzeOUTS}

What is the background to modern tender offer freezeout cases, such as the Siliconix and Pure decisions? Freezeouts structured as tender offers with short form mergers did not occur until the final years of the twentieth century. [130] Hence before this there was no tender offer freezeout doctrine per se. Nor has the supreme court addressed these transactions, to date.

In its Solomon decision, in 1996, the Delaware supreme court considered a controllers' tender offer to purchase minorities shares: but the transaction therein did not contemplate a second step cash-out merger. [131] Subsequently, in 2001 in its Glassman decision, the Delaware supreme court held that fiduciary fair dealings criteria are inapplicable to controllers' short-form mergers. But once again, even in Glassman, there was no deliberate combining of a tender offer and short form merger to go private. [132] Hence, tender offer freezeout doctrine is still very new. Many doctrinal issues relevant to these transactions have never been addressed, and none have been resolved by the supreme court authoritatively.

The contrast with cash-out merger doctrine is striking in this regard. The Lynch Doctrine (especially its unwaivering adherence to Entire Fairness for controllers' cash-out mergers) is the outgrowth of decades of judicial analysis.

Though the supreme court has not ruled expressly on a tender offer freezeout, it has ruled on controllers' self dealing transactions (other than cash-out mergers, that is).[133] Even in these other settings, the court has applied the Entire Fairness standard. Against this background, the court of chancery's recent “rebellion” against Entire Fairness for freezeouts appears anomalous indeed adventurous (from the perspective of stare decisis). In sum, because the Delaware supreme court has never expressly endorsed a departure from the Entire Fairness standard for tender offer freezeouts, it's premature to assume there are two genuine, separate "tracks" in freezeout doctrine - one mandating Entire Fairness and the other, far more lax.

This is true notwithstanding that in Siliconix and Pure, the court of chancery has presumed that the business judgment rule is the baseline. These decisions were based on Solomon's "no fair price duty absent malfeasance" [134] admonition, in combination with Glassman's rejection of a Entire Fairness for short form mergers. Accordingly, though neither Solomon nor Glassman 
expressly addressed a genuine tender offer freezeout, the decisions have exerted a formative influence on the court of chancery's fiduciary doctrine governing tender offer freezeouts. This influence is apparent in Siliconix, [135] Pure, [136] and Cox, [137] as described in detail in Part III.

The above discussion is not meant to suggest that tender offers or even short form mergers were unregulated or were uncommon through the twentieth century. This would not be true: each was practiced by acquirers in a variety of contexts. But they had not been combined as a vehicle for going private.

In Delaware, short-form mergers were authorized by mid-century, indeed even prior to "regular” cash-out mergers, and they became commonplace.[138]

As for tender offers, federal law has of course played the leading role through the Williams Act and the SEC's regulations promulgated thereunder. [139] Enacted by Congress in 1968, the Williams Act focuses principally on promoting full and accurate disclosure to the recipients of the tender offer. [140] It also includes certain anti-manipulation requirements intended to bolster target shareholders' ability to make unhurried, rational choices about whether to tender or hold their shares (as described below). With respect to disclosure, the Williams Act and SEC's regulations impose extensive disclosure requirements on bidders and on target directors in tender offers, [141] with substantial prohibitions on fraud to back them up. [142] Furthermore, in tender offer freezeouts -- where a controller combines a tender offer and short form merger -- the aforesaid disclosure requirements are further complemented by those arising under the SEC's going private rule, Rule 13e-3. [143] Finally, in tender offer freezeouts (as in other tender offers), the Exchange Act requires the target company's directors to publicize their opinion of the merits of the offer in a Schedule 14D-9 filing. [144] With respect to the anti-manipulation rules, where the bidder's offer is for less than all shares, there is a pro rata acceptance requirement which is designed to limit the pressure on shareholders to make hurried choices. [145] By virtue of Rule 14e-1(a) tender offers must remain open for at least 20 business days [146]. The SEC's rules also give shareholders the ability to change their mind by creating withdrawal rights. [147] Furthermore, the Williams Act requires that if the offeror increases the price before the expiration of the tender offer, the higher price must also be paid to shareholders who have already tendered. [148]

The legislative history of the Williams Act speaks loudly of Congressional intent to favor neither bidders nor targets; [149] hence neither controllers nor minorities in the case of tender offer freezeouts. Again, Congress' focus was on affording the offerees the information necessary to make rational, informed choices in their self interest. [150] Furthermore, the federal scheme is not intended to preempt state regulation of the rights and roles of bidders (controllers here) or offerees (minorities). With respect to financial matters: nothing in federal scheme addresses the appropriate allocation of gains from a freezeout tender offer (that is "fair price"). And with respect to fair process, nothing in federal tender offer regulation addresses the role of target directors in responding to a tender offer and/or protecting minorities' interests in the face of one. Congress, the SEC, and the federal courts have allowed state corporate law to occupy the field in regard to target directors' duties in tender offers: both with respect to third parties' 
(noncontrollers') and controllers' tender offers.

One explanation for why tender offers did not earlier become popular as vehicles for freezeouts is that it is impossible wholly to eliminate the minority shareholders through a tender offer. To transform a tender offer into a freezeout, controllers commonly effectuate a short-form merger after the tender offer is completed. Through the short-form merger, with they may effectuate unilaterally, controllers are able to eliminate the last, holdout minority shareholders. Section 253 of the DGCL provides that once a controller has obtained at least $90 \%$ of the outstanding voting stock of the target, it can effectuate the short-form merger almost immediately by making a simple filing with the secretary of state. [151] No agreement or negotiation with the target directors, or vote by the other, minority public shareholders is required. If a controller obtains $90 \%$ or more of the target company's stock in the tender offer, its power to effectuate the second step of the tender offer freezeout - that is, the short form merger - is assured.

Given that the transactional technology to combine tender offers and short form mergers had existed for decades, it's surprising that controllers had not seized this route for going private earlier. Probably the best explanation for this is that uncertainty over what standard of review governed the short form merger discouraged this technique. [152] Then in 2001 this ambiguity was eliminated. When the Delaware supreme court's Glassman decision resolved that the Entire Fairness standard would not be applied to short-form mergers, [153] many commentators predicted that tender offer freezeouts would eclipse cash-out mergers as the preferred going private format (because of the absence of the Entire Fairness imperative). However, the empirical evidence does not suggest that there's been any such dramatic shift in freezeout formats to date. [154]

A full critique of Delaware's tender offer freezeout doctrine appears in Part III. But some early observations are appropriate here. In their development of tender offer freezeout doctrine, the Delaware courts seem to have been guided, curiously, by the tenor of federal tender offer law. Second, the absence of a statutory tender offer provision in the DGCL made the courts uncertain about their role in promulgating standards for target directors and controllers in the latter's tender offer freezeouts. The state law prohibition on "fraud" and "coercion" was read to add little to the federal securities' laws' prohibitions and mandates. In this respect, the corporate doctrine governing tender offer freezeouts is highly distinct, if not anomalous from the fiduciary standards governing other self dealing transactions or most M\&A transactions. Even with respect to mergers with third parties, the duty of care is elevated. [155] And federal law's "disclosure-isenough" approach has not limited the growth of equitable standards relevant to boards' appropriate defensive response to third parties' tender offers.[156] That is, outside of tender offer freezeouts, in the M\&A area, extensive fiduciary requirements sit atop the state statutory and federal architecture. In sum, Delaware's passive response to target directors' fiduciary duties in responding to a controller's tender offer cannot be explained by de jure or de facto federal preemption.

Nor is it plausible that the Delaware courts have presumed that target shareholders are sufficiently protected from coercion by the bright line requirements of the Williams Act and the 
SEC's regulations (e.g. the all holders'-best price, pro-rata acceptance, minimum 20 days' time provisions, etc. described above) First, none of the cases suggest this rationale, either expressly or implicitly. Second, the legislative history to the Williams' Act evidences Congress' intent to maintain a "level playing field" - i.e. to favor neither bidders nor targets (the objective is reiterated in the federal cases interpreting the Williams' Act as well [157]). Since equity has seen fit to afford target directors defensive authority in the interest of protecting shareholders in regular tender offers (i.e. from coercive or inadequate bids), minorities would seem to warrant similar and indeed more protections from controllers' tender offer freezeouts - though this is not where the doctrine is at present..[158] Because robust defensive authority exists for target directors in "regular" tender offers, it cannot be that the Delaware courts' laissez faire approach to minorities' rights in controllers' tender offers reflects a considered judgment about the adequacy of federal protections. [159]

In explaining its rationale for limited minority protections in controller's tender offers, the court of chancery has often pointed to the fact that the DGCL is silent on the subject of tender offers - a fact which is indisputable. [160] The problem is, of course, that this silence is equally relevant to tender offers by noncontrollers, where the courts have afforded target directors ample defensive authority..[161] Where the Delaware case law addresses the silence in the statute, it has observed that no corporate level transaction occurs in a tender offer. But once again, this observation does not make sense of the gap between target directors' broad authority in regular tender offers and their slim or nonexistent defensive authority vis a vis controllers' tender offers. Nor does it account for statutory anti-takeover provisions such as Delaware's section 203, which is relevant to third parties' bids.[162] Prior to Pure, the Delaware court of chancery did not treat controllers' tender offers as self-dealing transactions - perhaps because, formally, they fall outside of the "at both sides" paradigm of a self dealing transaction. And they did not apply heightened equitable protections in minorities' interest..[163] But once again, the observation does not fit with the courts' affording defensive authority to target directors vis a vis third parties' tender offers.

\section{Freezeout Reform and Contemporary Public Policy}

The recent reforms to freezeout doctrine are being fueled and shaped by public policy and popular sentiment - more than legal precedent. The Cox Reforms coincide with two sweeping contemporary trends affecting corporate law and the capital markets. The first is the widespread acceptance of public companies -- even major public companies -- being taken private.[i] Changes in the credit markets have temporarily halted the pace of going private transactions. But depressed equity prices are likely to drive another wave of going private deals in short order. The Cox Reforms are expressly aimed at facilitating more freezeout transactions

The focus below is the success of law reforms intended to curtail investor class actions.[ii] The Cox Reforms are also expressly aimed at discouraging suits against freezeouts [iii] Even the invective against lawyers who file suits contesting freezeouts is part of this. [iv] Full consideration of the Cox Reforms thus requires some consideration of the utility of litigation (and the resulting case law) in shaping M\&A transactions and influencing capital market values. [v] 
The proper scope to be afforded investors' claims of fraud and overreaching (in a variety of transactional settings) has been a longstanding matter of controversy in corporate law. [vil At the national level, the contemporary push to limit shareholder suits began with Congress' enactment of The Private Securities Litigation Reform Act of 1995 ("PSLRA"). [vii] The PSLRA imposed significant procedural hurdles to plaintiffs' proceeding with securities class actions, which influenced shareholders' ability to contest a variety of M\&A transactions. [viii] Shortly thereafter, in the name of preventing savvy plaintiffs' lawyers from circumventing the procedural requirements established by the PLSRA, Congress enacted The Securities Litigation Uniform Standards Act of 1998 ("SLUSA"), which intensified this effect.[ix] SLUSA preempts most private investor class actions alleging misrepresentation under state securities law and common law fraud. Indeed, it came close to preempting (proscribing) fiduciary class action claims against freezeouts. $[\mathrm{x}]$ And notwithstanding the sweeping corporate governance reforms enacted in the Sarbanes-Oxley Act of 2002 ("SOX”), [xi] Congress eschewed provisions that might have increased investors' ability to bring class actions against corporate transactions of a variety of sorts. [xii]

As a last minute "save," in SLUSA, Congress left intact shareholders' ability to bring fiduciary class actions for fraud and unfairness against a variety of corporate transactions, including freezeouts. [xiii Nevertheless, many commentators and legal scholars claim that shareholder suits impose gratuitous costs on corporations and the economy, so that they should be radically limited. [xiv] These scholars and commentators argue that corporate fiduciary law would function adequately if it were essentially a hortatory, normative force. In this mode, the state courts would allow damages, or even allow claims to proceed to trial, only in the most egregious cases. [xv] Consistent with this trend, the Delaware courts have increasingly limited shareholders' ability to go forward with derivative and direct class. [xvi]

In sum, the jaundiced view of shareholder class actions and the lawyers who bring them reflected in the Cox opinion mirrors the widespread popular and policy viewpoint that investors can largely fend for themselves, and that markets are apt to increase wealth where there is minimal legal "intrusion.” [xvii] In just this vein, Cox contends that in freezeouts, the piece-work of equitable review is rarely worth the cost to the litigants and the economy. Its proposed reforms are intended to promote controllers' ability to have freezeout claims dismissed on the pleadings. [xviii] In this regard the Cox Reforms are inspired by this "pro-market/deregulatory" ideology, even more than by empiricism or doctrinal logic. [XIX]

By advocating retaining Entire Fairness as the presumptive standards for freezeouts, this Article parts company with commentary that portrays shareholder suits in unqualifiedly negative terms. It rejects the view that the M\&A and capital markets would thrive under a system of minimalist fiduciary safeguards and increased checks on shareholder suits. In the alternative, Delaware's seminal M\&A jurisprudence has validated transactional best practices that have helped balance controllers' and minorities' interests in freezeouts (and the welfare of bidders and targets in general). [XX] In specific, in the Weinberger tradition, the Delaware courts have validated the employment of special committees, independent legal and financial advisers, 
clearer heuristics for appropriate disclosure and other criteria designed to promote "fairness," “candor," impartial decision-making by boards, and truly voluntary consent by minorities. [XXI] In freezeouts, as in other high-profile M\&A transactions, the courts have assumed the role of "transactional choreographers," [XXII] and this transactional choreography - as it has shaped transactions and influenced the capital markets -- has the character of a public good. [XXIII]

The Cox Reforms would discourage many claims against freezeouts from ever being filed including some number of meritorious claims. With respect to claims which are filed, it would allow most of them to be dismissed on the pleadings. This raises interesting questions relating to legal process and the operation of corporate law as a public good. Most pertinently: can corporate law positively contribute its "transactional choreography" (and thereby limit agency costs in M\&A transactions) if most claims are dismissed on the pleadings? If the Cox Reforms are followed, how will the courts' message to deal planners and the markets be affected by this additional roadblock to freezeout claims proceeding?

Finally, from the perspective of corporate law production, will savvy plaintiffs' lawyers take their freezeout claims to other jurisdictions which might read Delaware freezeout doctrine differently - for example, by staying closer to the supreme court's dictates than the contemporary trends endorsed by the court of chancery? [XXIV]

\section{FAIR PRICE: InCONSISTENT LEgAL APPRoACHES}

At present, in Delaware, there are three distinct legal regimes that define minorities' financial entitlements in freezeouts. First, in tender offer freezeouts, consistent with the Solomon decision, [164] the court of chancery has declined to impose a (fiduciary/equitable) fair price duty on controllers. [165], Secondly, the appraisal statute provides that shareholders eliminated in a cashout merger are entitled to "fair value" in an appraisal proceeding. Appraisal proceedings can be brought against unitary (single step) cash-out mergers and short form mergers (the back end of tender offer freezeouts), however they cannot be brought by shareholders who regret selling into the tender offer portion of a freezeout. [166] Thirdly, as a matter of equity -- under Lynch's Entire Fairness standard -- minorities who are eliminated through a cash-out merger are entitled to receive a "fair price" for their shares.[167] Obviously, these three frameworks present nonequivalent, possibly conflicting financial entitlements for minorities in freezeouts.

There are two ways these financial entitlements are relevant to minorities. First, they define the remedies that minorities might obtain, ex post, in a contested freezeout. Secondly, probably most importantly, they influence freezeout prices ex ante: setting a benchmark for the prices that minorities will demand and the prices that controllers will offer in freezeout bids and negotiations. [168]

Finally, these background financial entitlements influence the market trading price of minority shares as a general matter - outside of freezeouts. Consistent with the efficient capital markets hypothesis, the prices that minorities will pay for their securities at the time of their 
original issuance will reflect a judgment regarding the securities' relevant risk/return profile. The risks will include the potential for opportunism by insiders, including controllers. [169] There are many factors that influence the risks relevant to an investment, of course. But it should be obvious that having three non-equivalent legal frameworks defining minorities' financial entitlements in freezeouts creates a distinct risk in itself. By creating inconsistent and opaque understandings about the financial entitlements attaching to a minority stake the law is promoting market failure in pricing these securities - in freezeouts and in general..[170]

Achieving clarity in the scheme of financial entitlements relevant to freezeouts should yield two forms of economic benefits. First, if minorities have a clear fair price entitlement, this will limit controllers' ability to use freezeouts to capitalize on their overall capacity for overreaching. Second, a clear, legal fair price entitlement in freezeouts should enhance private companies' ability to sell minority stakes in the public markets at an advantageous price. [171] Hence, achieving a unified doctrinal approach to fair price in freezeouts should benefit investors and companies overall. [172]

\section{A. Tender Offer Freezeouts: No Legal Standard for Price}

As stated earlier, the Delaware supreme court's decision in Solomon has come to stand for the proposition that controllers have no fair price duty in their tender offers. [173] As described further in Part III, there is little discussion within Solomon itself for this conclusion. The court simply states that in "totally voluntary" tender offers, shareholders will be able to make choices in their best interest. But the problem with the viewpoint, and the "no fair price duty" approach, is that it ignores the inherent and pervasive power advantages possessed by controllers.

The second problem is that in controllers' tender offers, the absence of a fair price duty is presently complemented by a weak role for the target board of directors. As mentioned above, in third parties' offers, as exemplified by Unocal, Delaware fiduciary law envisions an activist, defensive role for the target directors.[174] But this defensive authority has not been affirmed for target directors in controllers' offers, to date. [175] In a third party's tender offer, if the offered price seems low, the board or special committee will have a variety of defenses it can deploy while seeking financial or transactional alternatives. [176] In addition, if the third party's bid remains too low, an alternative, better bid will likely appear on the scene. Because outsiders cannot compete with controllers' offers on a level playing field (at least without the help of the target independent directors), the controller will benefit from the absence of a fair price duty. Additionally, the controller can use its voting power to thwart a sale to a third party, and to influence the board, in a variety of ways, to support its offer. [177] In addition, the controller can benefit from inside information to launch its freezeout; federal securities law disclosure duties are of some help here, but they are not a cure-all. Access to this kind of inside information, and the timing advantage it affords controllers, creates a substantial risk of opportunism in freezeouts. This risk, too weighs in favor of a fair price duty in controllers' offers. [178]

These advantages are not relevant to third parties’ bids. Third parties must compete against the 
market for corporate control. Third parties will not ordinarily have inside information giving them an advantage over other bidders. Nor will they be able to use the threat of inherent coercion in their favor. For this reason, the fair price duty is not appropriate vis a vis third parties' tender offer bids.

Corporate law's role in reducing agency costs -- and hence firms' cost of capital -- is also a reason to enforce a fiduciary fair price duty in controllers' bids. [179] Where the controller's presence is deemed to reflect a heightened risk of opportunism and overreaching, the minorities' shares will trade at a discount to the firm's going concern value. [180] The controller's power to use the threat of self dealing to force the market stock price downward - which would make an unfairly low tender offer freezeout bid comparatively attractive - gives it an unfair benefit in a freezeout, and one which is harmful in general. If controllers are not legally required to pay at least pro rata going concern value in their tender offer freezeouts, then they will have an incentive to press the board to undermanage the firm and to overreach to drive down the market price of the minorities' shares in anticipation of launching a freezeout. [181] In the absence of a fair price requirement, the greater the controller's malfeasance, the deeper the market's apprehension, the steeper the market trading discount, the lower the price the controller can offer and still succeed in a tender offer freezeout. [182] In sum, the absence of a fair price duty in controllers' tender offer freezeouts is a hole in the web legal prohibitions protecting minority shareholders and capital market values.

\section{B. APPRAisal’s “FAir VAlue” StandARd (AND CASH-OUt MERgers)}

Delaware's appraisal statute [183] offers some financial redress for shareholders who are eliminated through a cash-out merger at less than "fair value" (as defined by statute). [184] By its express terms it applies only in a merger (or consolidation, but not a tender offer) and only in one based on cash consideration. [185] Appraisal could possibly be available in the back end, shortform merger portion of a tender offer freezeout, but appraisal is not a possibility for shareholders who sell into a controller's tender offer, as mentioned above. [186]

Section 262(h) of the DGCL provides that in an appraisal action shareholders should receive the "fair value" of their shares. [187] According to the statute, the court of chancery shall:

determine the fair value of the shares exclusive of any element of value arising from the accomplishment or expectation of the merger or consolidation, together with interest, if any, to be paid upon the amount determined to be the fair value. In determining such fair value, the court shall take into account all relevant factors.

As evident from the express language, valuation in appraisal actions is complicated by the fact that the statutory language gives only this loose definition of fair value. [188] Given this loose mandate to take into account "all relevant factors" in performing the appraisal, the task of creating a workably clear standard of "fair value" has fallen to the courts.

There are certain longstanding ambiguities in the definition of fair value reflected in the 
Delaware case law. [189] The thorniest of these relates to which forms of post-merger gains should be included in "fair value." [190] But leaving aside this significant problem,[191] the core concept of fair value for appraisal purposes is clear and has remained so: shareholders are entitled to be receive the value of what has been taken from them in the transaction.[192] For purposes of an appraisal, corporate shares represent a pro rata interest in the company valued as a going concern. "Fair value” is thus often referred to as "going concern value” or “intrinsic value.” [193]

"Going concern value" was enshrined as the core concept of appraisal's "fair value" by the mid 20th century, as reflected in the often cited case of Tri-Continental Corp. v. Battye. [194] Thirty years later, the Delaware supreme court cited Tri-Continental favorably and expansively in Weinberger's landmark treatment of fair value in appraisals. That is, in Weinberger the court validated going concern value as the core concept of appraisal value. (It's remarkable but true that Weinberger both established the foundation of modern fiduciary freezeout doctrine for cashout mergers and also the foundations of modern appraisal methodology, as relates to the concept of fair value.) Weinberger rejected the mechanistic "Delaware block method" that had governed valuations in appraisal actions previously. [195] In its place, the court endorsed "a more liberal approach ... [to] include proof of value by any techniques or methods which are generally considered acceptable in the financial community...." [196] Consistent with the forward-looking notion of going concern value, and modern finance theory, discounted cash flow is the most accepted valuation methodology for appraisal actions. [197] Most importantly for this discussion, Weinberger affirmed that appraisal is intended to be an expansive, and that courts engaged in appraisals should proceed accordingly. [198]

The expansive, forward looking interpretation of "fair value" established by Weinberger has held to the present. For example, the supreme court's decision in Glassman affirmed Weinberger's expansive approach to fair value analysis in appraisals. As stated in Glassman:

[t]he determination of fair value must be based on all relevant factors, including damages and elements of future value, where appropriate. So, for example, if the merger was timed to take advantage of a depressed market, or a low point in the company's cyclical earnings, or to precede an anticipated positive development, the appraised value may be adjusted to account for those factors. [199]

Glassman's definition of appraisal's fair value thus expressly speaks to the problem of opportunistic timing in cash-out mergers, which is a special concern in freezeouts. In addition, Glassman, like the other modern cases interpreting fair value in appraisals, attributed little significance to the public trading price of the minorities' shares, consistent with the concern over the minority discount in the public markets. [200]

The logic of appraisal value as going concern value has held up remarkably well under contemporary financial economics. [201] In particular, the fair value requirement allows valuecreating freezeout mergers so long as minority is not left worse off -- that is, so long as the merger is Pareto-superior. [202] This fits with the economics-based logic that Delaware corporate law should encourage transactions that increase wealth, as long as no party to the transaction is 
left worse off. [203]

Unfortunately for minorities in freezeouts, there are features of the appraisal statute that radically limit its utility. These limits and hurdles often make appraisal's "fair value" an unobtainable remedy for minorities in freezeouts.[204] As described previously, the Delaware statute contemplates that appraisals are available only in mergers.[205] Appraisal's fair value is unavailable to shareholders who sell to a controller in a tender offer. Indeed, aware of this, controllers often launch "clean up" tender offers even where they have executed a cash-out merger contract - as a device to limit their financial exposure to appraisal actions. Second, In addition, appraisal is unavailable if the freezeout contemplates that the consideration in the merger will be securities. This is true whether the securities are those of the controller or another publicly traded corporation, irrespective of whether the securities have voting rights. This limit is remarkable given the controller's unilateral ability to determine the number and kind of securities offered in the cash-out merger. [206] Minorities must formally dissent from the merger in order to go forward with an appraisal action.[207] Also, appraisal rights can be perfected only by the record holders of the shares [208] - a formalistic requirement which creates confusion and indirectly defeats some number of valid appraisal claims. Also, the time period for initiating an appraisal action is brief -- 120 days from the date of the merger. [209] Hence it is not uncommon for minority shareholders to miss this window of opportunity to proceed with an appraisal. In order to proceed with an appraisal, the plaintiff shareholders are generally required to submit their stock certificates to the Register in Chancery, and may have their action dismissed if they fail to do so. [210] Appraisal proceedings last four years on average, [211] and shareholders will not have received any consideration for the shares prior to their conclusion - a factor which deters many appraisal proceedings.[212] Finally, the absence of a class-based mechanism for proceeding in appraisal actions limits their efficacy. [213] The costs of pursuing individual and even consolidated appraisal actions are often prohibitive for minorities.

In sum, leaving aside the clarity of appraisal's promise of going concern value, the limits and practical hurdles that apply to appraisal proceedings have sent negative signals to minorities about their ability to obtain fair value via appraisal actions. Accordingly, as they weigh the relative merits of proceeding with a freezeout, and which route to choose, controllers can significantly discount the cost of judicial appraisal awards. Appraisal's limitations mean that the equitable cause of action arising under Lynch's Entire Fairness standard is of great importance for minorities confronting a freezeout.

\section{C. “FAir Price” and Equitable Actions against Cash-Out Mergers}

Professors Gilson and Gordon have described the cause of action arising under Lynch's Entire Fairness standard as "the equivalent of a class appraisal proceeding without the need for shareholders actually to perfect their appraisal rights." [214] While true in some respects, the statement fails to take account of meaningful quantitative differences between "fair value" and "fair price." To backtrack, the professors are absolutely correct that the equitable cause of action for fair price is not limited by the myriad formal requirements which limit appraisal's efficacy.[215] This is in itself is a powerful argument for rejecting the Cox Reforms and refusing 
to limit Entire Fairness in freezeouts.

But even focusing narrowly on quantitative metrics, there are reasons to believe that the equitable "fair price" standard promises minorities something better than "fair value." [216] As stated in Weinberger, if the controller is found culpable of gross misconduct "[the] appraisal remedy ... may not be adequate in certain cases, particularly where fraud, misrepresentation, selfdealing, deliberate waste of corporate assets, or gross and palpable overreaching are involved.” [217]

This possibly higher range of "fair price" was validated, also, by the Delaware supreme court's decision in Cede \& Co. v. Technicolor, Inc.,[218] a case which involved a fiduciary action against a controller's cash-out merger. In Cede the court indicated that rescissory damages, or their financial equivalent (indeed any expansive financial remedy deemed equitable under the circumstances) could be made available in a fiduciary action -- whereas the same would not be true in an appraisal action. Cede affirmed that while the equitable remedy is extraordinarily open ended, going concern value sets a hard upper limit in appraisal actions. In an appraisal, the courts have discretion to award interest going back to the merger date (to compensate for the value-loss attributable to the delayed payout).[219] They also have discretion to award litigation costs to the plaintiffs. [220] But based on the statutory language, as interpreted, appraisal's "fair value” is indifferent to malfeasance by an acquirer -- even where the acquirer is a controller/fiduciary. In this regard, especially when the practical impediments to bringing an appraisal action are accounted for, the appraisal remedy is likely to under-deter fiduciary wrongdoing in freezeouts.[221]

Looking to the substance of corporate fiduciary law, there are additional reasons to conclude that the base line of fair price is higher than fair value's. It is well acknowledged that the remedy for breach of fiduciary loyalty may encompass disgorgement of profits by the fiduciary. Where a fiduciary is found to have taken a corporate opportunity, for example, the Delaware courts have endorsed imposing a constructive trust to recapture the profits for the benefit of the shareholders. [222] In addition, where a fiduciary has exploited confidential corporate information to profit personally, shareholders may bring a derivative action to force disgorgement of such profits irrespective of showing harm to the corporation. [223]

The academic commentary has mostly elided the difference between fair value and fair price. Unfortunately, Weinberger itself contributed to the supposition that the two financial standards will often be congruent. [224] However, the "arms' length dealings" language in Weinberger suggests a price standard larger than fair value. If fair value affords minorities only a claim to what has been surrendered in the cash-out merger, then they need not enjoy any gain from the transaction. The controller would be free to capture all upside - all the anticipated synergy gains from the merger. Although appraisal's fair value does not require that the cashed-out shareholders be made better off from the deal, the equitable remedy would seem so to imply. Again this is implicit in the integrated approach Weinberger takes to "fair price" and "fair dealings.”

Nor is Weinberger an outlier in this regard: in all fiduciary self dealing actions the 
defendant/fiduciary must prove that it did no better (and the beneficiary/shareholders did no worse) than they would have if bargaining at arms' length in the market. This by definition implies that both sides should benefit in a "fair price" world. No rational independent directors dealing at arms' length would allow all the benefits to go to one side. Hence there's no reason to believe that rational, independent directors dealing with controllers at arms' length would allow the controller to capture all the benefits from a freezeout. Furthermore, there are transaction costs attendant to freezeouts that incur to the minorities' detriment if they do not share some measure of the anticipated gain. Hence, the Entire Fairness standard and its fair price metric, as applied in duty of loyalty analysis, requires that a transaction sponsored by a fiduciary must be mutually beneficial (though not necessarily equivalently so) in order to be fair.[225]. This is as true in freezeouts as it is in other self dealing transactions.

Again, this is evident in Weinberger itself. At several junctures the opinion states that fairness in a cash-out merger should be equated to the outcome that would have occurred if the parties were genuinely dealing at arms' length. As stated in the opinion's famous footnote 7:

... fairness in this context can be equated to conduct by a theoretical, wholly independent board of directors acting upon the matter before them, it is unfortunate that this course apparently was neither considered nor pursued.... Particularly in a parent-subsidiary context, a showing that the action taken was as though each of the parties had exerted its bargaining power against the other at arms' length is strong evidence that the transaction meets the test of fairness. [226]

As stated above, truly independent directors bargaining at arm's length would not agree to a transaction that merely left "its side" no worse off. Hence, this oft-cited passage from Weinberger supports an understanding of "fair price" that is broader than that contemplated by appraisal's "fair value." The same language and logic also explains why Weinberger insisted that fair price and fair dealings are inseparable - that the determination of fairness is not a bifurcated one between fair price and fair process. [227] The court's constant return to the "as if at arms' length" heuristic affirms that "fair price” is intended to afford minority shareholders some measure of the synergy gains from controllers' cash-out mergers, as is not true in fair value as going concern/replacement value. [228]

In sum, the equitable standard for "fair price” is not identical with appraisal's "fair value;" although they are both relevant to minority shareholders cashed-out through mergers.

\section{The NeEd For A Uniform Legal Price Rule for FreEzeOUTS}

The above discussion reveals why the equitable fair price remedy is not duplicative of or gratuitous in light of the appraisal remedy. It also illuminates that the absence of any legal price framework for controllers' tender offers is an outlier. This discussion further illuminates that the nonequivalent and indeed idiosyncratic price regimes relevant to freezeouts are undeserving minorities' interests. Given these highly complex and nonequivalent legal price constructs 
relevant to freezeouts, it is impossible to believe that the capital and securities markets can aptly price the risks attaching to minority equity investments.

In this respect, the three non equivalent price regimes relevant to freezeouts are most likely contributing to market failure. This market failure may influence pricing at several junctures. A lack of awareness of the true risks would inflate the price of the securities where private companies issued minority stakes in public offerings. Alternatively, if market participants were aware of the gross uncertainty created by these nonequivalent, ambiguous price regimes, this could accentuate a discount in the price of these minority stakes, which might increase the cost of selling public equity stakes unnecessarily. Finally, if the market is sensitive to gaps in remedies for self-dealing by controllers, and there is no effective fair price remedy in a freezeout, then controllers can push the limit of self-dealing and profit thereby in executing a freezeout at a deep discount to going concern value.

Companies which were taken private in the past decade may soon seek to sell minority equity stakes in the public markets. If the fiduciary protections against controllers' self-dealing are not shored up - and if the disparate financial entitlements in freezeouts are not "ironed out," then minorities should pay relatively less for these securities than they otherwise would. This would be a bad result for the economy and for public companies in general. [232]

Though it has not commonly been observed, there is one important limit to controllers' capacity to obtain "the best of all possible freezeouts" by arbitraging these different freezeout formats and their comparative advantages. That is: once a controller has executed a cash-out merger agreement with the board of the controlled entity, the Entire Fairness standard "sticks" to the freezeout. This is true even if the controller elects to switch to a tender offer for its freezeout -- the courts have applied the Entire Fairness standard to the entire transaction. In this respect, the Entire Fairness standard has operated as a uniform backstop against controllers' overreaching in freezeouts and provided minorities meaningful leverage in bargaining with controllers. This leverage would be lost if the business judgment rule became the presumptive standard for freezeouts, consistent with the Cox Reforms. In light of the uncertainty being created by the three legal price frameworks, and the "two tracks" in freezeout doctrine, the Delaware courts should adopt a unified fiduciary standard for freezeouts - one which encompasses a fair price requirement, consistent with Entire Fairness.

\section{IN FLUX: CONTROLLERS’ DUTIES IN TENDER OFFER FREEZEOUTS}

\section{A. BACKground to THE Recent Tender OfFer FreEzeOUt CASES}

This Part of the Article focuses on the court of chancery's recent reforms to tender offer freezeout doctrine. [233] It finds fault with the notion, endorsed by Pure and Cox, that allowing business judgment deference in tender offer freezeouts accompanied by Dual Ratification would provide a robust safeguard of minorities' interests in tender offer freezeouts. [234] While it is unambiguously clear that Pure and Cox raise the playing field for tender offer freezeouts, their 
new criteria are incomplete and entirely too subject to manipulation by controllers. As such, they should not be allowed to create an end-run around Entire Fairness review. [235]

A major problem with the new, bright line rules for tender offer freezeouts presented in Pure and Cox is that they are not situated within a fiduciary, "fair dealings" framework. This is part of their being incomplete and too easily subject to manipulation by controllers. [236] In addition, in both Pure and Cox the court of chancery has eschewed imposing a fair price requirement on controllers' tender offer freezeouts. As described immediately above, this has negative implications for minorities' ability to bargain in the face of controllers' tender offer freezeouts, and hence their ability to sell to controllers at a good price.[237] Accordingly, although they appear to raise the level of judicial oversight over that pertaining ex ante, Pure's and Cox's proposed new standards for tender offer freezeouts are largely window dressing. They would perpetuate the minority discount and further controllers' capacity to profit from overreaching in freezeouts based on tender offers.

In order to prepare for a detailed review of Pure's and Cox's proposed reforms to tender offer freezeout doctrine, this section of the Article provides a detailed discussion of the Solomon, Glassman, and Siliconix decisions which are their antecedents. These three decisions form the essential backdrop to understanding both the ambitions and the defects which inhere in the reforms proposed in Pure and Cox.

The conclusion of this Part III is that allowing deferential business judgment rule review of tender offer freezeouts upon adherence to the Dual Ratification framework espoused by Pure and Cox would still leave minority shareholders vulnerable in these transactions. This is a bad result for minority shareholders, as well as corporations and the capital markets more broadly.

\section{The Solomon Decision}

That Solomon has been accepted as the landmark decision governing controllers' fiduciary duties in tender offers is very surprising, in several respects.[238] First, the opinion is only an affirmation by the Delaware supreme court of the court of chancery's grant of the defendant's motion to dismiss. [239] Thus, the substantive questions of fiduciary duty which were at the heart of the plaintiffs' complaint were not aired in a trial.

Secondly, more remarkably, Solomon includes only a very abbreviated discussion of the substantive fiduciary law precepts for which the opinion becomes "famous" -- that is, controllers' and target directors' limited fiduciary duties in tender offers. To the contrary, most of the Solomon opinion focuses on the pleading standards applicable to fiduciary class actions. The central issue before the court is the standard to be applied to dismissals for failure to state a cause of action. [240] The plaintiffs argued that the lower court had erroneously applied a heightened pleading standard, but the supreme court disagreed. Hence it affirmed the court of chancery's dismissal of the complaint in Solomon. [241]

That the transaction disputed in Solomon was not a genuine freezeout adds to the incongruity 
of the opinion's stature in freezeout doctrine. The controller, Credit Lyonnais Bank, was conducting a tender offer for the small slice of Pathe Communications' public equity that it did not own. Contemporaneously, it was also foreclosing on the $89.5 \%$ interest that it held as collateral on a loan. On the day the tender offer was announced, the controller initiated an auction to sell the $89.5 \%$ stock interest subject to the pledge. [242]

Although the case is accepted as landmark precedent on the scope of controllers' duties in tender offers, the plaintiffs' amended complaint (as described by the supreme court) alleged only fiduciary breaches against the controlled company's directors. [243] A close reading of Solomon illuminates that the court was struggling with whether it should scrutinize the propriety of the controller's or the directors' conduct -- and the reasoning expressly confuses the relationship between these two distinct fiduciary questions.

The confusion is striking because in Solomon the supreme court made absolutely clear that the amended complaint contained only two counts, both against the controlled company's directors. As described therein, the first count alleged a breach of care by the target directors (in failing to "negotiate a sufficient tender offer price"). The second count alleged that the directors failed to oppose the tender offer. [244] The supreme court affirmed the court of chancery's decision that both counts failed to state a triable issue of fact or law.[245]. But instead of addressing this matter of the target directors' passivity in the face of the controller's tender offer -- the supreme court merely reiterated the finding of the chancellor below that there was not "a fleeting doubt of the fairness of the ... \$1.50 tender offer price.” [246] That is, the supreme court addressed its attention to the substance of the bid, instead of the adequacy of the directors' response to it. On the question brought by the complainants -- whether target directors could remain entirely passive in the face of a controller's tender offer - the court offered no analysis whatsoever.

In Solomon, the supreme court's failure to consider the substance of the plaintiffs' claims is especially odd because these were essentially breach of care claims, and in breach of care claims the Delaware courts usually focus on the adequacy of the process followed by the directors, rather than the substantive merits of the disputed transaction.[247] Here, to the contrary, the court avoided inquiring about the adequacy of the target directors' conduct, and looked to the substantive adequacy of the offer - obviously, an entirely separate issue.[248] Solomon's failure to discuss the extent of target directors' defensive duties and authority in controllers' tender offers is a major shortcoming in the opinion and, strangely, it has inhibited the development of Delaware case law on controlled companies' directors' duties to the present day.[249]

Returning to Solomon's discussion of controllers' duties in tender offers, again it is quite limited and problematic even in the limited assertions made. First, as mentioned above, the court's assertions about price are unrelated to the claims brought by the plaintiffs (which again were alleging breach of duty by the directors). Second, there is no inherent, logical link between whether controllers have a fair price duty and whether the directors did or did not negotiate vigorously in the minorities' interest. The two legal issues are logically independent. On the issue of the adequacy of the price offered, in the dictum that has made the case famous, the Solomon court stated: "[i]n the case of totally voluntary tender offers ... courts do not impose any 
right of the shareholders to receive a particular price." [250] The court cited the no fair price principle as if the issue had been resolved earlier, and definitively. But this was not the case. Indeed, the cases cited for the proposition do not support this conclusion. [251]

In specific, Solomon cites the Vickers Energy litigation and the Weinberger decision [252] as precedent for there being no fair price duty in controllers' tender offers. However, as clarified below, neither of these decisions come close to supporting this conclusion. The lower court opinion cited by the court in the Vickers Energy litigation was overturned on appeal in a manner that expressly cast doubt on the portion of the opinion cited in Solomon. [253] And as for Solomon's reference to Weinberger (which involved a cash-out merger), the latter says absolutely nothing about controllers' tender offers. To reiterate, nothing either express or implied in Weinberger supports the view that controllers have no fair price duty in making a tender offer for minorities' shares. Furthermore, since Weinberger unequivocally affirms controllers' fair price duty in cash-out merger freezeouts, there isn't even a hint in the opinion that the supreme court would affirm that controllers have no fair price duty in a tender offer. [254] Hence, Solomon interprets the Vickers Energy and Weinberger decisions incorrectly. Nor is Solomon even faithful to the overall spirit of the Vickers' Energy or Weinberger decisions, both of which place tremendous importance on corporate law's role in supporting minority shareholders' capacity for free choice. [255] In sum, although Solomon has been treated by the court of chancery as a landmark decision resolving that controllers have no fair price duty in making a tender offer for minorities' shares, the opinion nowhere provides any relevant precedent or principled rationale for this conclusion. [256]

Furthermore, although Solomon concludes that no fair price duty pertains in controllers' tender offers that are "entirely voluntary," the court failed to give meaningful attention to the conditions of voluntariness in controllers' tender offers.[257] That is a remarkable gap in a Delaware supreme court decision - but it's less than mysterious once one appreciates that so little of the court's attention was addressed to the substantive fiduciary duty matters in Solomon. Again, the standard for dismissals was the major issue before the court. Hence, Solomon unreflectively accepts that "total voluntariness" means the absence of fraud or express coercion by the controller. [258] This gap between the absence of fraud and coercion and the facilitation of a totally voluntary freezeouts is explored, seven years later, in the Pure decision. [259] $* \mathbf{8 2 2}$

In conclusion, there are fatal flaws in Solomon's treatment of controllers' tender offers.[260] And these flaws have had a substantial effect on Delaware freezeout doctrine, especially because the supreme court has not had an occasion to revisit the fiduciary doctrine governing controllers' tender offers in the ensuing years.

\section{The Glassman Decision}

It was only in 2001 that the Delaware Supreme Court resolved that the business judgment rule rather than the Entire Fairness standard would apply in short-form mergers. [261] Nor was this result a foregone conclusion. The supreme court's 1971 opinion in Schnell v. Chris Craft Industries, Inc. expressly validated the Delaware courts' equitable authority to supplement 
statutory mandates in matters of corporate governance.[262] Hence Schnell seemingly provided authority for the supreme court to rule that the Entire Fairness standard's requirements of fair price and fair dealings applied in short-form mergers. Indeed, the equitable principles endorsed in Schnell were applied most commonly in situations where a board's or shareholders' scope of authority had been abridged or circumvented inappropriately.[263] Short-form mergers are intriguing in this regard, because the statutory terms expressly provide controllers the power to bypass the target's board and even the target's remaining, minority shareholders. [264] Lynch itself had also force to the idea that Entire Fairness was the appropriate standard of review for short-form mergers. In Lynch the supreme court had described Entire Fairness as the "exclusive" standard of review for parent companies' cash-out mergers of their subsidiaries. [265]

Weighing in the opposite direction, however, was the Delaware supreme court's 1962 decision in Stauffer v. Standard Brands, Inc. [266] In Stauffer the court had held that absent fraud or wrongdoing, appraisal would be the sole remedy available to dissatisfied minorities contesting short-form mergers. [267] Controllers considering going private based on tender offers anxiously awaited the supreme court's resolution of Glassman v. Unocal Exploration Corp. [268]

In 2001, in Glassman, the supreme court held that no equitable, fair dealings requirement would pertain in short-form mergers. It based its decision on the notion that judicial implication of a fair dealings requirement would expressly conflict with the streamlined process envisioned in the Delaware General Corporate Law. Reviewing the decision carefully, it is apparent that the court did not consider the issue cut and dried. The court reviewed five decades of equitable decision-making in long and short-form mergers before it announced its holding deference to the legislature precluded the application of fair dealings requirements in short-form mergers. [269] Glassman held, furthermore, that in light of the absence of the fiduciary fair dealing requirement, valuation disputes in short-form mergers would be reviewable exclusively through appraisal proceedings. [270] According to the court, appraisal would provide the exclusive recourse for aggrieved shareholders in short-form mergers “absent fraud or illegality.” [271]

Hence, after 2001, by combining the dictates of Solomon and Glassman, controllers were empowered to proceed with combining tender offers with unilateral, short-form mergers as vehicles for going private - and vehicles for avoiding judicial oversight under the Entire Fairness standard of review. [272] These decisions were a comfort to controllers who sought to avoid intensive judicial oversight of their freezeouts. [273]

However, its arguable that controllers and courts have erred in reading Glassman so broadly. The Delaware supreme court may not have intended to resolve that Entire Fairness does not apply to (the back end of) tender offer freezeouts. [274] Glassman itself did not involve any such "premeditated" tender offer freezeout.[275] Furthermore, because prior to Glassman controllers had very rarely relied combined tender offers and short form mergers as vehicles for going private, there is reason to doubt that the supreme court realized the significance of its holding for freezeouts. [276] And, as is true with respect to Solomon, in the six years since Glassman, the Delaware supreme court has not had occasion to revisit the implications of its decision. 
In sum, Solomon and Glassman are unreliable as authority for the view that controllers have no equitable fair price or fair dealings obligations in tender offer freezeouts. On the same basis, they cannot reliably be understood to resolve that there are two distinct tracks in freezeout doctrine: the Entire Fairness standard for cash-out mergers, but no fiduciary fairness criteria for tender offer freezeouts. In this respect, the court of chancery decisions addressing tender offer freezeouts have over-read the implications of Solomon and Glassman. Certainly, the court of chancery is going too far in invoking these decisions as a basis for rebelling against the Entire Fairness standard for freezeouts.

\section{B. SILICONIX: DELAWARE's FIRST TENDER OFFER FREEZEOUT DECISION}

\section{Siliconix's Facts}

In Siliconix the court of chancery had its first opportunity to review a going private transaction structured as a combined tender offer and short-form merger. [277] Siliconix provides a provocative illustration of how far a controller could go in exerting a dominating influence over the controlled company's board and minority shareholders, while successfully avoiding judicial intervention on grounds that it had committed fraud or coercion. [278] In this respect, Siliconix represents a "cautionary tale” of controllers' power to overreach in tender offer freezeouts in the absence of fiduciary safeguards.

The target of the freezeout was Siliconix Inc., a NASDAQ listed technology company that had suffered through the market correction of early 2000. [279] The controller, Vishay Intertechnology Inc, owned $80 \%$ of Siliconix's stock and operated in the same line of business as Siliconix. [280] As described by the court, Vishay was attempting to exploit what appeared to be a fleeting opportunity to acquire Siliconix's publicly traded shares at a favorable price. Indeed, the freezeout allowed Vishay to eliminate a potential competitor. [281]

In February 2001, without prior notice, Vishay announced a cash tender offer for all of Siliconix's shares. [282] Its SEC filings and public disclosures Vishay declared a "probable" intention to consummate a short-form merger after the tender offer closed; hence the minority shareholders could not be assured they'd have appraisal rights if they refused to tender. [283] Vishay also announced that Siliconix would probably be delisted from the NASDAQ at the conclusion of the tender offer. [284] This announcement would have deepened the minority's concerns about the diminished liquidity and diminished value their shares would suffer after the tender offer's consummation. Notwithstanding the federally mandated disclosure requirements, Vishay was equivocal about its motives for the freezeout. [285] In particular, it failed to enunciate a rationale for the price it was offering in its tender offer for the minorities' shares. [286] In these respect Vishay's disclosures skirted the edge of legally acceptable disclosure. [287]

Vishay's tactics suggested a perfunctory effort to comply with the standards enunciated in Solomon. For example, Vishay declared its willingness to negotiate with a special committee of Siliconix's independent directors.[288] However, the resulting committee was quite obviously dominated by Vishay. [289] Of the two special committee directors, one had been Vishay's lawyer 
until shortly before the transaction. [290] The other "had been active in providing banking services" to Vishay several years earlier. [291] In addition, both special committee directors "were friends of Vishay management (including Vishay's chief negotiator in the freezeout).[292] The aforementioned lawyer/director was appointed to the negotiating committee at the suggestion of the person who would serve as Vishay's principal negotiator. [293] The opinion also indicates that the two committee directors had been promised a special fee from the controller contingent on the freezeout's consummation - a shocking fact given they were serving as agents of the minority shareholders. [294] Hence, as described by the court itself, in Siliconix there was no basis to conclude that the committee directors were truly acting in the best interest of the minority shareholders[295]. However, this finding had no effect on the court's ruling.

Nor is the composition of the committee "worse" than the other features of the transaction. The controller had vetted the special committee's selection of financial advisers. [296] And the financial advisers' fee, too, was contingent on the freezeout's consummation. [297] Finally, the committee's legal adviser cautioned that "Vishay could not be compelled to sell its stake in Siliconix" and could "commence a unilateral offer at any time." [298] Once again the court's exhaustive recitation of the facts suggests reasons to be concerned about coercion in the freezeout. In fact, the opinion reads like a "worst case scenario" of corporate governance in freezeouts. Yet despite the court's description of the compromised composition of the committee, the ambiguous and incomplete disclosures, the vetting of the committee's advisers, the problematic "special fee" arrangements affecting the committee and its financial adviser, the unilateral switch to stock consideration, and the surprise timing of the original offer, Siliconix did not conclude that the controller's freezeout should be stopped. Indeed, the court of chancery rejected the minority shareholders' requested.

Indeed, although the court paid lip service to Solomon's criteria of "total voluntariness," [299] the facts set forth in its opinion suggested there were many aspects of the freezeout which inhibited the shareholders' freedom to choose not to tender to Vishay. As stated above, Vishay's federally mandated disclosures were equivocal about its motive for going private, and silent regarding the basis for the price offered.[300] And Siliconix's directors assumed a posture of neutrality in the Schedule 14D-9, so the minority investors did not even have guidance from their directors in evaluating the merits of the controller's offer. [301] Finally, the special committee did not attempt to obtain a fairness opinion from its financial advisors - hence this possibly helpful information was also unavailable for the minority's consideration. [302]

In regard to the financial fairness of the freezeout tender offer, the court stated that in its original cash offer, Vishay "made no effort to value Siliconix," but instead merely applied a 10\% premium to the prevailing public trading price of the stock. [303] It also observed that Vishay even lowered its final offer as part of its switch to stock consideration. [304] In addition, the switch to stock consideration and finalization of the offer's other basic terms were resolved and publicized without prior notice to the special committee ostensibly representing the minority. [305] The controller's only bow to concerns over fair process was its apparent observance of a "majority of the minority" minimum tender condition. [306] In sum, Vishay's tender offer freezeout for Siliconix's outstanding publicly-traded shares presents remarkable facts, facts that suggest patent 
coercion and overreaching on the controller's part. And yet the court refused to intervene in the minorities’ interest.

\section{Coercion and Inadequate Disclosure by Controllers}

In Siliconix the court even departed from the lax prohibitions against fraud and coercion enunciated in Solomon, in a way that biased the proceedings against the plaintiffs. In addition to having to meet the usual, heightened standard of irreparable harm applicable to obtaining an injunction, [307] in Siliconix the court ruled that the plaintiffs were required to show "actual" fraud, "improper" coercion, or conduct that was "coercive in some significant way." [308] Again, this reading goes beyond that "required" by Solomon itself. The court seems to have gone far out of its way to allow the freezeout, at the same time that its opinion suggests that the court found the facts worrisome. [309] Even as the court denied the injunction, it expressed consternation over the "lesser scrutiny" applied to controllers' tender offers in comparison to cash-out mergers. [310]

In Siliconix, even the analysis of the adequacy of the controller's disclosures appears biased in its favor. In the earlier decided Vickers Energy opinion, the Delaware supreme court had mandated that controllers' tender offer disclosures must meet a standard of "complete candor." [311] But in Siliconix the court of chancery ignored Vickers Energy's admonition about controllers' tender offer disclosures.[312] Rather than applying the "complete candor" standard, the court asked merely whether the plaintiffs had proven there were material misrepresentations by the controller. This analysis seems distorted both in terms of its substance (material misrepresentation versus complete candor) and the allocation of the burden of proof. In Siliconix the court concluded that “... [the plaintiff] has not met his burden of a preliminary showing that there was a disclosure violation," [313] and arrived at this conclusion despite the seemingly gross disclosure flaws it had enumerated.

\section{Directors' Duties in Tender Offer Freezeouts}

The preceding discussion of Siliconix focused on the court's analysis of the conduct of the controller, Vishay. Siliconix is also important for its treatment of target directors' duties in tender offer freezeouts. [314] (Both the controller and the target directors were named as defendants in the breach of fiduciary duty class action.) [315] Because in Solomon the supreme court had avoided this subject, and in Glassman the court ruled against applying fiduciary fair dealings criteria to short-form mergers, the Siliconix court found itself working off of a nearly clean slate. There was virtually no direct precedent speaking to the nature and scope of target directors' fiduciary duties in freezeouts based on tender offers.

Reviewing their actions, the court found the special committee directors' conduct passive and wholly ineffectual. [316] Nonetheless, consistent with the strangeness of the rest of the opinion, the court concluded that the special committee directors had satisfied the fiduciary duties they owed the minority shareholders in the freezeout. [317] To be more precise, the court reviewed the breaches of care and loyalty on the directors' party alleged in the complaint, [318] but then truncated its analysis of the complained of facts. Instead, it switched to a discussion of 
the Entire Fairness standard. The court stated that "unless coercion or disclosure violations can be shown, no defendant has the duty to demonstrate the entire fairness of this proposed ... transaction.” [319] In sum, as had been true in Solomon, in Siliconix the court conflated the standard governing the controller's conduct with that applicable to the target's directors.

At a later stage (the opinion is quite disorganized), the court once again inquired into the directors' responsibilities in tender offers. It noted that the DGCL is silent about directors' roles in responding to tender offers[320], and attributed substantial import to this statutory silence in resolving that though wholly passive and ineffectual the directors had satisfied the equitable duties they owed to the minority in this setting [321] Hence, in Siliconix the court elided the obvious difference between statutorily mandated director obligations and directors' fiduciary duties (which of course arise from the case law's interpretations of equitable principles). [322] Secondly, the court rationalized that target company shareholders make individual decisions to hold or sell in tender offers, rather than there being a "corporate" event.[323] Most notably, what the Siliconix court failed to discuss was the accepted activist role of target directors in responding to inadequate tender offers by third parties (noncontrollers) in the Delaware jurisprudence. The absence of a "corporate level" event has not prevented the courts from recognizing expansive fiduciary duties for target directors facing inadequate or coercive bids from third parties. ding against hostile tender offers from noncontrolling shareholders or outsiders. [324]

The Siliconix court paused over the issue of the adequacy of the committee directors' conduct just long enough to be troubled by the implications of a recent ruling from the Delaware supreme court, McMullin v Beran. [325] In McMullin the supreme court held that the target directors might have breached their fiduciary duties by remaining passive in the face of the controller's preferred sale transaction. [326] The Siliconix court even commented at length that in the freezeout before it and the sale contested in McMullin, the minorities' "need for (and ability to benefit from) the guidance and information to be provided by their boards" was virtually "indistinguishable.” [327] In Siliconix, court also observed, that the financial alternatives for the minorities were analogous in the two instance. They could "take or leave" the deal consideration offered unilaterally by the controller (without meaningful guidance from their directors) or they could attempt to pursue an appraisal action (although no appraisal rights were ensured in the Siliconix transaction, as stated previously) [328].

The supreme court's disapproval of the target directors' passivity in McMullin clearly caught the court of chancery's attention in Siliconix. At this juncture, too, it seemed that the court was deeply sympathetic to the minority's plight, and would rule in its favor - that the directors might have failed to fulfill their fiduciary duties to the minority in remaining entirely passive in the face of the controller's preferred transaction.

But here too in Siliconix the court went out of its way to rule in favor of the controller. It made much of seemingly minor, formalistic differences between the two transactions. (In McMullin, the controller had forced a sale of the company through a merger with a third party,[329] whereas in Siliconix the directors were facing a tender offer freezeout.) It read McMullin as counseling 
that directors of Delaware corporations have affirmative fiduciary duties if the controller is forcing through a disadvantageous corporate sale, [330] and found no such sale in the freezeout.[331] As it read McMullin, directors' fiduciary duties are crucial in corporate sales, but not in tender offer freezeouts - a distinction of little difference to the minority in Siliconix. Finally the court made much of the different statutory framework for tender offer freezeouts and cash-out mergers. [332] But in so doing the court made far too much of the statutory distinction, while it ignored the Delaware fiduciary precepts relevant to target directors' duties in tender offers. In sum, Siliconix is an unsatisfying and provocative decision on many levels, and its treatment of target directors' duties in responding to tender offers by controllers is particularly unsatisfying.

Based on the result, these shortcomings were grossly apparent to Vice Chancellor Strine as he wrote his decision in Pure.

\section{Pure Resources: New Preconditions for Deferential Review n Tender Offer FREEZEOUTS}

\section{The Facts in Pure}

The tenor of Pure suggests a generally favorable view of Unocal's freezeout offer. [333] And certainly Unocal, the controller in Pure, proceeded in a manner that seemed less domineering than the controllers in the freezeouts challenged in Siliconix[334] and Aquila. [335] Nevertheless, upon closer examination, the facts set forth in Pure reveal that Unocal unhesitatingly sought to benefit from its superior negotiating leverage, [336] from disclosure deficiencies, [337] from a committee whose independence may have been compromised, and from consent terms that systematically favored its interests. [338] Perceiving the latter forms of self-interested conduct, certain minority shareholders of Pure Resources, Inc. sued for a preliminary injunction against Unocal's proposed tender/exchange offer. [339] And they obtained the requested preliminary injunction, although their victory meant relatively little. The court ruled that Unocal, which owned 65.4\% of Pure's shares, [340]) could go forward with its tender offer freezeout once it (i) disclosed valuation data prepared by the investment bankers hired by the special committee, (ii) provided a fuller description of the communications that had occurred between the special committee and Unocal's representatives over the scope of the committee's authority, [341] and (iii) amended the majority-of-minority consent provision to eliminate the counting of shares in the minority group which had conflicting financial interests. [342] These were easy "fixes." [343] They allowed Vice Chancellor Strine, in his ruling in Pure, to advocate sweeping law reforms plausibly beneficial to minority shareholders facing tender offer freezeouts (especially compared to Siliconix). The court granted the requested injunction, but in so doing compromised the controller's ability to go forward with the freezeout only in the smallest measure. [344] Indeed, Unocal promptly consummated its tender offer freezeout after it implemented the changes identified by the court. [345]

Pure describes the background of Unocal's freezeout offer in great detail. Unocal had been involved in Pure's business operations since Pure's inception. [346] As part of the creation of Pure, 
Unocal obtained a shareholder voting agreement that gave it control over five of Pure's eight board seats. [347] Unocal also benefited from a "Business Opportunity Agreement" that allowed it to take commercial opportunities that otherwise might have been deemed (consistent with the corporate opportunity doctrine) to belong to Pure. [348] The competitive operations of Unocal (the parent) and Pure (the subsidiary), the prospect of favorable market conditions and the availability of ready financing options for the subsidiary - together with the fact that Pure had genuinely independent and ambitious senior executives [349] at its helm - all created friction between the parent and the subsidiary which led to the freezeout offer.

Initially, Unocal's interest in acquiring Pure was out in the open and widely known to Pure's senior management. [350] In the fall of 2001, however, Unocal gave Pure's CEO notice that it had resolved not to proceed.[351] Unocal's interest in going forward returned, however, by the following summer, but did not make itself public until Unocal announced a "surprise" freezeout tender/exchange offer. [352] During the summer of 2001, as part of its original investigation into a freezeout, Unocal's representatives on Pure's board had gathered confidential information from Pure. [353] That Unocal had "permission” from Pure's management to do so [354] (as described in the court of chancery's opinion) illuminates how conflicted Pure's CEO and COO, were[355], especially in light of their possessing valuable severance agreements which would be triggered by a successful freezeout. [356] The court noted that Pure's management and Unocal's representatives had discussed the fact that proceeding through a single step cash-out merger was probably untenable; [357] presumably that meant that the insiders believed the transaction would not pass muster under the Entire Fairness standard. (Especially problematic was the fact that seven of the eight directors had financial interests potentially conflicting with the unaffiliated minority stockholders' [358]). In this respect, the freezeout in Pure represents a vivid example of controllers engaging in structural arbitrage.[359]

Unocal appears to have been well advised by counsel. It proceeded with the freezeout in a way that was highly strategic and self-interested, and yet not patently coercive.[360] For example, Unocal did nothing to thwart Pure's establishment of a special committee. [361] On the other hand it aggressively interceded to limit the special negotiating committee's defensive authority when this appeared vital.[362] In this vein, the opinion suggests that the committee's conduct would not have measured up to Weinberger's criteria of "arms' length dealings." The court of chancery noted that Keith Covington, one of Pure's two special committee directors, was "a close personal friend" of the controller's President and COO. [363] Also troubling is the fact that after negotiations over the freezeout's terms had commenced, Unocal took a harder line in enforcing the Business Opportunities Agreement ("BOA") than it had previously. For the first time, it barred Pure's pursuit of an opportunity that implicated Unocal's commercial interests. [364] The controller's new approach to the BOA would reasonably have been interpreted by Pure's directors and minority shareholders as a sign of Unocal's willingness to exploit its power advantages if the freezeout were defeated -- i.e. classic inherent coercion in operation.

As the negotiations over the freezeout progressed, Unocal's representatives on Pure's board refused to recuse themselves from the special committee's deliberations. [365] This would have inhibited the special committee directors' candor in responding to the controller's offer. Finally, 
most palpably, when the committee ultimately marshaled its courage and sought authority to pursue alternatives more consistent with all the shareholders' interests, Unocal's representatives on Pure's board sounded the alarm. They aggressively confronted the special committee.[366] The controller's vehemence immediately quelled the special committee's “insurgency." [367] The court was definitive that Unocal had acted aggressively towards the committee to intimidate it into backing down, [368] though some of the details were unclear.[369]. (Some of Unocal's directors at Pure had invoked the attorney client privilege to protect themselves from potential liability.) [370] It was clear that the confrontation resulted in a pared down version of the committee's mandate (based on the board's resolution). Thus the committee's efforts to block the controller ended.[371] The committee's rebelliousness was expressed, merely, in its refusal to endorse the controller's offer in the Schedule 14D-9. [372]

Again, at a superficial level, Unocal's offer was attentive to fair process issues - that is, the relevant transactional choreography. [373] Nevertheless, the opinion reveals significant grounds for concern about coercion and overreaching on Unocal's part. For example, although Unocal agreed to a majority-of-the-minority minimum tender condition, consistent with the minority's interest, [374] that minority approval condition was tainted by the conflicting financial interests that existed within the what was denominated the "minority" block. [375] Unocal adopted a 90\% minimum tender condition, and agreed to consummate a short-form merger if it hit the target level. However, the controller reserved the right to waive the $90 \%$ floor; that is, to close the tender offer even if less than 90\% of Pure's shares were acquired.[376] The waivability of the 90\% floor meant that at the front end - at the time the minority shareholders would be making their choice about whether or not to tender -- they would not know whether there would be a subsequent short-form merger affording them appraisal rights. [377]

Furthermore, Unocal treated the special committee's recommendation as supernumerary: it did not condition it's going forward on the committee's approval (which it did not receive). [378] And, indeed, Unocal did proceed and close its tender offer despite the committee's stance of neutrality in the Schedule 14D-9, as mentioned earlier. [379] (Subsequently, in Cox, the court of chancery affirmed that special committee approval should be a prerequisite to deferential judicial review for tender offer freezeouts, as described below.) [380] In addition, Unocal had openly declared it was unwilling to sell its shares to a third party,[381] which radically decreased the chance that a better, third party offer for the company would surface in the market. The disclosures to the minority had not included the valuation studies conducted (purportedly) in the minorities' interests by their financial advisers. (This the court required Unocal to rectify as a prerequisite to going forward.)[382] Just as importantly it would seem, the minority shareholders were not told about the committee's failed efforts to obtain blocking power and investigate alternative transactions.[383] Also, the opinion notes that the committee did not obtain an improvement from Unocal in the exchange ratio (over that originally announced). [384] And because the court of chancery declined to apply Lynch's Entire Fairness standard, and instead endorsed Solomon's "no price duty" standard, Pure does not contain any analysis of whether the consideration offered the minority was adequate. The court merely noted the offered exchange ratio, [385] and Unocal's observations about the size of the premium over the market trading price. [386] 
Some apology for this lengthy description of the facts in Pure is in order. But these worrisome facts suggest how disinclined the court was to act aggressively in the minority's interest. The facts are thus highly relevant to this Article's normative conclusions about importance of applying the Entire Fairness standard even in tender offer freezeouts. The court of chancery enunciated new standards for deferential review in tender offer freezeouts - thereby raising the bar for controllers. [387] And the facts in the transaction are directly relevant to the bright line rules for future tender offer freezeouts endorsed by the court in Pure. [388] These bright line, anti-coercion rules have proven popular.[389] For example, Professors Gilson and Gordon have written that they "... share the Pure court's conclusion that a fully empowered special committee, including the Pure anticoercion litany and the right to say "no" affords sufficient process so that entire fairness review in a freeze out merger can be eliminated." [390] For this reason, the tide pushing against Entire Fairness in freezeouts is strong, despite these several opinions illustrating the continuing incidence of coercion by controllers therein.

This discussion of the coercive pressures brought to bear by Unocal in its freezeout is intended to quell enthusiasm for loose judicial oversight in freezeouts. In the detailed review of the facts of Unocal's freezeout above, the ongoing extent of controllers' coercive power comes into view - including controllers' willingness to subvert the efforts of independent negotiating committees. In Pure the court of chancery chose to emphasize the more savory elements of the offer: the absence of express threats of financial retribution, the formal constitution of a special negotiating committee (that had its own advisers), the majority of the minority consent requirement, and the controller's (albeit contingent) promise to execute the short-form merger. At the same time, the court gave relatively less emphasis to several deeply worrisome attributes of Unocal's conduct. By invoking the Solomon standard instead of Lynch's Entire Fairness standard, the court of chancery had room to object only to problems which the controller could fix expeditiously. Viewed against the Entire Fairness standard, Unocal's conduct in its freezeout would have appeared unsatisfactory; against the loose standards of Solomon, it could be saved.

\section{Doctrinal Analysis and Pure's Holding}

Pure's holding should be stated with clarity at this point. First, the court ruled that the Solomon tradition, rather than Lynch's Entire Fairness standard, provided the proper framework for analyzing Unocal's freezeout offer. [391] The court also expressed its view that Solomon's "more flexible" standards for freezeouts are generally preferable to Lynch's "rigid" Entire Fairness standard.[392] Ambitiously, the court improvised off of Unocal's freezeout to codify certain preconditions to business judgment rule deference in tender offer freezeouts. As presented therein, these new preconditions include: (i) the absence of express threats of financial retribution if the freezeout fails, (ii) the observance of a majority-of-the-minority shares minimum tender condition, (iii) a promise to complete a short-form merger if the controller reaches more than 90\% ownership in the target, and (iv) the controller allowing the special committee (if one exists) to consult independent advisers and formulate an opinion on the merits of the transaction. [393] 
It should be noted that Pure's legal analysis is exceptionally wide ranging and thoughtful. The court discussed three strands of Delaware case law potentially relevant to tender offer freezeouts: first, Solomon "anti-coercion” standards, [394] second, Lynch's Entire Fairness Doctrine [395] and third, Unocal's progeny relevant to third party tender offers. [396] After this doctrinal "survey," in Pure the court of chancery endorsed the new, objective, "anti-coercion" criteria enumerated below as preconditions to deferential review of the freezeout. In so doing, the court took a positive step in the direction of protecting minority shareholders in tender offer freezeouts, [397] compared to the status quo ante.[398] Yet Pure is ultimately dissatisfying because it stops short of endorsing adequate protections for minorities in tender offer freezeouts.

Again, the court of chancery's first bold move was its unqualified affirmation that Solomon (and Glassman), and not Weinberger and Lynch, were the appropriate doctrinal framework for reviewing the tender offer freezeout. [399] This had earlier been the route taken by the court of chancery in Siliconix [400] and Aquila, [401] but the latter were far less wide ranging and insightful than Pure. Hence Pure's affirmation of the Solomon/Glassman tradition for tender offer freezeouts is salient and bold.[402]

Remarkably, although the court declined to apply Lynch's Entire Fairness standard, in Pure the court expressed that inherent coercion by controllers is inadequately addressed within the Solomon tradition for freezeouts.[403] Indeed, the court expended considerable effort to describe how inherent coercion operates just as forcefully in tender offer freezeouts as it does in cash-out mergers, if not more forcefully, in its view. [404] (Presumably, this was the basis for its departure from the more powerfully laissez faire interpretations of Solomon.) Unfortunately, while the court of chancery paid lip service to the problem of inherent coercion in tender offer freezeouts, it proposed reforms fall far short in imposing requirements or standards of review which would appropriately redress such coercive power. [405]

In its less than vigorous treatment of inherent coercion in tender offer freezeouts, the court returned to the presumption that minorities can act in their self interest in freezeouts, so long as the anticoercion "tests" it endorses are followed.[406] If they are, Pure, affirms, then business judgment deference should apply to the freezeout - consistent with Solomon's logic. [407] But the varieties of coercion noted in Pure are more wide ranging than the anticoerion rules adopted therein. [408] In the end, Pure's doctrinal choices - the endorsement of an anti-coercion litany -do not seem to be driven by a conviction that they adequately redress coercion by controllers; [410]), indeed, in Pure the court observes that minorities lack adequate leverage under the Solomon framework.[411]). Rather, the driving force in Pure (and then in Cox) appears to be the court's policy preference for limiting litigation in freezeouts and encouraging these transactions.[412] These policy preferences are made explicit in the opinion, moreover.[413] The court concludes that these policies mandate in favor of Solomon's "flexible" standards,[414] in lieu of Lynch's which are too "constraining" and "litigation-intensive." [415]

Ironically, most of the first half of Pure involves a lengthy "defense" of the need for a minority-protective jurisprudence in tender offer freezeouts[416]. The court observed the unequal bargaining power between controllers and minorities in freezeouts. [417] The court also affirmed 
that controllers have timing, informational, organizational, market and legal power advantages which they can use to their advantage in both forms of freezeouts.[418] Throughout Pure's lengthy discussion of the Lynch Doctrine's validity, it seems that the court intends to expand the application of Entire Fairness to tender offer freezeouts. [419] After this lengthy validation of controllers' coercive power in tender offer freezeouts it's surprising when the court endorses a short list of rules for "relatively noncoercive" tender offer freezeouts.

Pure is also the first Delaware decision openly to address the disjunction between special committee's authority in regular tender offers (based on the progeny of Unocal Corp. v. Mesa Petroleum Co. [420] and Moran v. Household Int'l, Inc. [421]) and their limited defensive authority in the face of controllers' tender offers. [422] A brilliant jurist, Vice Chancellor Strine is of course entirely fluent in the nuances of Delaware's takeover jurisprudence. As a doctrinal matter, his rejection of committee defensive authority is startling and unsatisfactory. [423] And the issue was front and center before the court in Pure, because the committee had mounted a defense and been quashed.[424]

Again, Pure's failure to afford the special committee full defensive authority is a most unsatisfactory feature of the opinion. As a matter of statutory law, it is the board of directors that has authority to define the scope of a committee's power, not the shareholders. So it is odd, as a matter of corporate law, that Pure affirmed the controlling shareholder's power to truncate the special committee's authority. [425] Furthermore, since Pure's board owed fiduciary duties to all the shareholders equally (consistent with the basic precepts of corporate law), [426] it's virtually impossible to see how the board could justify limiting the committee's authority to explore whether there were transactional alternatives more consistent with all the shareholders' interests.[427] This is shortcoming in the opinion, to be sure.[428] On the subject of the special committee's being “shut down," Pure is mostly silent. Nevertheless, Pure would have delighted controllers in its observation that they need not allow a committee authority to deploy a poison pill, and that a committee need not defend against a controller's unsatisfactory tender offer freezeout. As justification for this minority-unfriendly stance, the court noted merely the "awkward sociology" of controlled boards and the "burdensome" implications for the common law of a contrary rule. It did not unpack or defend what it meant by either, however.[429] In another unpersuasive move, in Pure the court rationalized that the statutory underpinnings of poison pills are less than solid. [430] In sum, in Pure, the court failed to reconcile the jurisprudence affording target boards defensive authority in tender offers with its ruling limiting such defensive authority in tender offer freezeouts.

With respect to special committees, to recap, in Pure the court held (merely) that the controller must afford committees access to advisers and the time required for them to reach an informed judgment about the offer.[431] In the end, remarkably, in Pure the court merely required that controllers not stand in the way of special committees doing their job in taking some position vis a vis the offer, as already required by SEC Schedule 14D-9. Furthermore, Pure did not attribute independent significance to the committee's view of the merits of the controller's offer. The fact that the committee elected neutrality did not feature in the court's ruling.[432] In this regard, Pure takes the opposite approach from Weinberger, where the court afforded great 
weight to whether there had been an agent acting vigorously as the minority's agent in the freezeout.[433] Commentators have erred where they have concluded that Pure supports a robust role for special negotiating [434]

\section{Closer Analysis of Pure's New Requirements}

Pure's new criteria for determining whether a freezeout qualifies for deferential review each merit consideration.

First, the requirement that the controller cannot have made any express threats is, in essence, an historical artifact. [435] (It reflects that in the cash-out merger in Lynch, the controller threatened the committee that it would commence a tender offer at a lower price if the committee failed to approve the cash-out merger. [436]) Especially given the role of counsel in modern M\&A practice, it would be truly odd to find a record of a controller making such an express threat. Put simply, there is no need. Minorities, special committees and the capital markets are already well aware of controllers' powers of financial retribution. Hence, the absence of express threats by the controller is no indication of the freezeout's voluntariness.

Second, even a majority-of-the-minority tender condition only mitigates the prisoner's dilemma. It surely does not eliminate it.[437] There is enormous pressure to tender, even where the controller's price is well below going concern value. Shareholders contemplating a controller's intent on a tender offer know that they are legally powerless to maintain the status quo. If the tender offer fails, the controller can switch to a cash-out merger, which it probably can compel unilaterally.[438] Despite Pure's added protections, shareholders' "reward" for refusing to tender is that they will own shares that are more illiquid, probably delisted or trading at a deeper discount. Otherwise, if there is a short-form merger, they may (though not assuredly so) be able to pursue a costly, protracted appraisal action to obtain fair value. These vulnerabilities loom large as the tender offer's deadline approaches. Hence, a majority of the minority minimum tender condition, as endorsed in Pure, is also a weak safeguard of the minority’s best interest. [439]

Nor is Pure's proposed minimum tender condition analogous to the majority of the minority voting consent under the Lynch doctrine.[440] The dynamics in tender offers favor tendering, in a way that is not analogous to voting. Justice Jacobs noted this disparity in his opinion in Emerging Communications, [441] for example. And even in Pure the court noted disparities between mergers and tender offers that pressure minorities to tender. [442] Most obviously, shareholders who dissent in a merger can still receive the merger consideration, whereas nontendering shareholders are simply left behind. In addition, the more accelerated timing in tender offers exerts pressure on investors to sell, [443] and the looming deadline increases the salience of the premium over the market price. [444] The short time frame limits the target board's ability to ascertain if alternatives more favorable for the minority are feasible, even where the controller has allowed the special committee such liberal authority. [445] These factors operate cumulatively and pressure minorities to sell in tender offer freezeouts. Finally, under the Lynch doctrine, the minority's voting their approval merely would shift the burden of proof; in contrast, 
in Pure the court proposes that the easier-to-obtain minimum tender condition should serve as a critical indicia of the freezeout's voluntariness.

Lastly, Pure's "90\%-short-form merger" provision is also ineffective in meaningfully mitigating the pressure on minorities to tender. [446].4477 First, in a fatal flaw, Pure's short form merger provision simply gets the numbers wrong. Section 253 of the DGCL allows controllers to consummate a unilateral, short-form merger once they own "at least" $90 \%$ of the shares.[448] In contrast, in Pure the court provides that the tender offer freezeout will be deemed noncoercive if the controller commits to effectuate a short-form merger at an equivalent price if it acquires more than $90 \%$ upon the tender offer. [449] This disconnect means that a controller could acquire precisely $90 \%$ of the minority shares and Pure's short form merger provision, including its guarantee of an equivalent price in short form merger, would be irrelevant [450] Hence, Pure's short form merger provision does not reduce the controller's ability to "squeeze" the minority in the front end of the tender offer freezeout, because it does not guarantee a minimum price at the back end (This defect is of uncertain significance. Perhaps this numerical defect in Pure's shortform merger provision is a simple misreading of the statute. Perhaps the court meant "at least 90\%" (i.e. the statutory standard) instead of "more than 90\%" (as stated in the opinion). [451] But the short-form merger requirement is a core element of Pure's "anti-coercion" proposals, which would suggest that the court gave it thorough consideration. [452].)

The minority shareholders would also reasonably fear being left holding "super-minority" shares. They will fear that there will not be any short-form merger at all, and hence no recourse to appraisal. If a very small segment of the minority retains their shares because they believe the tender offer price is inadequate, they may end up with stock that is effectively unmarketable and valueless. Selling to the controller privately, at a later date, at a price of the controller's choosing may be their only viable option. Appraisal rights would not apply to such ad hoc, private stock sales. In this respect, too, Pure's short-form merger "anti-coercion” requirement falls short of its mark.

Perhaps most important, even if the short-form merger does materialize promptly, and is at an equivalent price as the tender offer, under Pure, that tender offer will not have been subject to a fair price requirement This is the most radical result of Pure's rejection of the Lynch Doctrine in favor of Solomon. [453] Furthermore, Pure's new, bright line "anti-coercion” requirements are not part of a broader fair dealings mandate. The duty of fair dealings is a feature of the Lynch Doctrine -- which Pure expressly rejected for tender offer freezeouts. Absent the fiduciary framework, Pure's new anti-coercion rules are highly manipulable for controllers. [454]

Finally, Pure's treatment of Unocal's disclosures to the minority is also troubling. First, as was true in Siliconix, Pure allocates the burden of proving a disclosure problem to the minority. This is anomalous: in Delaware cases where fiduciary self-dealing is present [455] courts require the party relying on the "informed" shareholder vote (which would be the controller in this instance) to demonstrate the adequacy of the disclosures.[456] Second, in the court's discussion of the S-4 and the Schedule 14D-9, the court again failed to apply the "complete candor" standard to the controller's disclosures, consistent with Lynch v. Vickers Energy, as noted previously. [457] 
In sum, although an extensive portion of Pure is devoted to describing controllers' myriad opportunities for coercing minority shareholders in tender offer freezeouts, the opinion's new anti-coercion criteria fall short of protecting minorities in these transactions.

\section{The Cox Decision Adds Another SPECIAL CoMmitTeE REQUIREMENT}

The Cox opinion amends Pure's anticoercion criteria for tender offer freezeouts in one important respect. Cox recants the part of Pure's holding that attached no significance to the special negotiating committee's position on the offer.[458].

It's essential to have the limits of Pure's committee provisions clearly in mind in order to appreciate what Cox does and does not add to the mix. To review, Pure's standards for target independent directors are very limited. The court held merely that where a controller is found to have hindered the target's directors from serving as informed, impartial advisers to the minority, the freezeout would not be presumed fair (hence ineligible for business judgment rule deference).[459] Furthermore, in Pure the court did not create an affirmative fiduciary obligation on the part of controllers to create special committee (i.e. to allow the target board's to do so). Pure merely assumes that such a special committee will have been created. Pure does not address the equitable effect of the controlled company's board failing to constitute a committee. (Nor is it clear that Cox resolves this issue.) [460] Second, Pure did nothing to reinforce meaningful standards for independent directors. To the contrary, in the transaction therein the court counted "a close personal friend" of the controller's President and COO as an independent member of the special committee.4461] Finally, the court expressly allowed that it was acceptable for the controller to hinder the special functioning. Unocal's representatives participated in meetings where the committee was deliberating. [462] And, most remarkably, Pure's allowed the controller to deny the committee blocking power and power to investigate alternative offers.[463]. [464] Finally, Pure did not afford the special committee's failure to approve of the offer any independent significance.[465] [466]

Cox revises Pure's stance on the importance of committees' opinions for the standard of review. [467] According to Cox, if the committee disapproves of the freezeout, then the Entire Fairness should apply. [468] On this point the Cox opinion is absolutely clear: committee disapproval should mandate the application of the Entire Fairness standard.[469]. There are important caveats here, however. First, Cox provides only that the committee's disapproval will preclude deferential review of the transaction. [470] The committee's disapproval does not constitute the freezeout coercive or unfair as a legal matter. Secondly, Cox does not provide that committees must be given real arms' length negotiating authority in tender offer freezeouts, in the spirit of Weinberger. [471] Cox simply does not address the part of the Pure opinion that allowed the controller to block the committee's defensive authority. [472] Neither Pure nor Cox resolves the disturbing disparity between target directors' expansive authority in third party hostile tender offers and target directors' circumscribed authority in responding to controllers' tender offers.

The second important shortcoming in Cox's special committee provision is that it is stated 
ambiguously in the opinion. [473] Stated most succinctly, it is unclear what effect Cox would give to a special committee's decision to remain neutral in a tender offer freezeout. The court first states that deferential review would apply only if the committee did not "disapprove" of the freezeout.[474] Subsequently, the court states that the committee's approval is a prerequisite for deferential review. [475] This second version raises the bar: neutrality would trigger the Entire Fairness standard.

The effect of committee neutrality in determining the standard of review is likely to prove highly significant, actually. Special committees will be under great pressure not to disapprove of a controller's tender offer -- at worst to be neutral. [476] Such neutrality is a valid option as far as Schedule 14D-9 is concerned.[477] Given that neither Pure nor Cox gives the committee defensive authority -- hence power to drive alternative options into the open -- the attraction for the committee of remaining neutral would be intensified. Also highly significant in this setting is the absence of a fair price duty. [478]). Combining these two limits affecting committee power, [479] "neutrality" will commonly be the wisest course for committees concerned about the value offered by the offer - especially given the legal presumption that absent outright fraud minorities can decide for themselves whether to tender to controllers. [480] If neutrality is sufficient for business judgment rule review, then committees will be under tremendous pressure to remain neutral at worst. The result is that neither the committee nor the courts would be appropriately enabled to protect minorities.

Indeed, Cox does not present its new committee feature as part of a law reform agenda aimed at protecting minorities in freezeouts.[481] The tenor of Cox is radically different from Pure in this respect. In Pure the court seemed ambivalent about balancing minority protections with the goals of limiting suits and facilitating freezeouts. In Cox the court embraces the latter goals wholeheartedly, and expresses little if any concern for minorities' vulnerability in these deals. [482] Furthermore,[483] in addition to reducing shareholder litigation in freezeouts, and encouraging more freezeouts, [484], the court is focused on the goal of unifying freezeout doctrine (under the business judgment rule). These goals overshadow concerns over minorities' vulnerability in freezeouts.

\section{E. CONTEMPORARY TENDER OFFER FREEZEOUT DOCTRINE, IN SUMMARY}

The ambiguities in Cox's conflicting special committee provisions are one salient example of the shortcomings in the court of chancery's approach to $* \mathbf{8 4 7}$ reforming tender offer freezeout doctrine. A fair dealings requirement for tender offer freezeouts, would not magically define the scope of unacceptable conduct by controllers therein. But a background fiduciary fair dealings requirement would foreseeably alter the climate, so that controllers would not systematically have the upper hand.

The imposition of a fair price requirement in controllers' tender offer freezeouts would have the same salutary effect. Without such a fair price requirement, controllers can do better in tender offer freezeouts precisely on account of the equity market's apprehension of controllers' capacity for self-dealing. As discussed further in Part V, minorities need a fair price requirement in hand 
in order to negotiate effectively with controllers.

Thirdly, neither Pure nor Cox make sense of the doctrinal disparity (and logical inconsistency) in special committees having expansive defensive authority vis a vis noncontrollers' unsolicited offers, but not in tender offer freezeouts.

Finally, neither Pure nor Cox effectively grapples with the "total voluntariness" standard enunciated in Solomon or the "complete candor" standard enunciated in Vickers Energy. Lynch's Entire Fairness Doctrine, and not the Solomon standards (even as amplified by Pure and Cox) provides the appropriate foundation for the future of freezeout doctrine.

\section{SCRUTINIZING THE EFFECT OF ENTIRE FAIRNESS IN FREEZEOUTS}

This Part analyzes the court of chancery's recent criticisms of suits and settlements in cash-out mergers. These criticisms of the Entire Fairness standard are enunciated most clearly in the court's Cysive[485] and Cox[486] opinions, as analyzed below. These criticisms of the effects of Entire Fairness set the backdrop for this Article's defense of the positive effects of the fair price and fair dealings requirements in freezeouts, set forth in Parts V and VI, respectively.

\section{A. Cysive Derides EnTIRe FaIRNESS ReVIEW}

\section{The Facts in Cysive}

Unlike most corporate law cases, in Cysive there was a trial fully airing the facts. The focus of the case is the fairness of cash-out merger proposed by Nelson Carbonell, Cysive's founder, CEO and controlling shareholder. [487] Carbonell had sold a minority interest in Cysive in a public offering in 2000, earning more than \$62 million in the transaction. [488] Shortly after the public offering, as we know, the market for technology stocks suffered a huge loss, and then an attempted business reorganization by Cysive also failed. [489] Both Carbonell and Cysive's board (composed of independent and management directors) agreed that fundamental change was necessary if the company was to avoid liquidation. [490] They hired an investment bank and commenced a search for a buyer. [491] After months of searching and not receiving any credible offers, Carbonell offered to purchase the remaining publicly traded shares. [492] His good faith toward the minority was manifest in his allowing an ongoing search for a third party buyer (i.e. while he negotiated the minority's acquisition via cash-out merger).[493] In addition, the price he offered exceeded the current market trading price of the stock, and also the company's anticipated liquidation value. [494] In the end, the court held that Carbonell's cash-out merger met the Entire Fairness standard - but not before it railed at the inconvenience and "inefficiency" associated with Entire Fairness review. [49]

\section{Litigating Factually-Intensive Questions in Equity}

The opinion begins by noting there was a disagreement about the relevant standard of 
review. [496] The plaintiffs argued that Carbonell was a controller, hence Entire Fairness applied. [497] The defendant argued that he was not, so the business judgment rule applied. [498] The court observed that the answer was not self-evident because Carbonell owned just under $40 \%$ of Cysive's voting shares, hence possessed less than absolute voting control. [499] Consistent with established precedent, nevertheless, the court combined Carbonell's managerial role [500] with his voting power and concluded he was a controlling shareholder - hence subject to Entire Fairness. [501] (In the language of this Article, a de facto controller). The court's combining voting and managerial power in analyzing the question of control represents an expansive approach to the Entire Fairness standard, but not an unorthodox one. Nevertheless, had the court been searching for a principled way to avoid Entire Fairness and streamline the proceedings, it had the opportunity to rule against Carbonell's “controller" status and apply the business judgment rule to the cash-out merger. [502]

Instead, Cysive issues a sweeping indictment of the effects of Entire Fairness review under the Lynch Doctrine. It condemns what it describes as the exceptionally factually intensive nature of fair dealings analysis, noting its relevance to both the burden shift issue and the resolution of the merits of the claim. [503] The court criticized this feature of Entire Fairness review as "miring" suits against freezeouts in "time consuming questions that are of little practical consequence." [504] Lynch has "so entangled the determination over the standard of review with the resolution of the merits that the two inquiries are inseparable," according to Cysive. [505] In sum, the court condemns the Lynch Doctrine for making much of little and preventing the efficient adjudication of freezeout suits. [506] Despite Weinberger's clear mandate, Cysive questions whether the Lynch Doctrine (review of freezeouts under Entire Fairness) should be perpetuated at all. [507]

The claims about the hypertrophied complexity of suits under the Entire Fairness standard are odd in several respects. First, once self dealing is present, all claims of fiduciary breach are governed by the Entire Fairness standard - at least as there starting point. Second, nuanced, context-specific standards and complex facts are the hallmark of Delaware's M\&A jurisprudence.[508] (Many of the insights set forth in Cysive were elaborated two years earlier by Vice-Chancellor Strine in a (co-authored) article published in The Business Lawyer.[509] The article advocated in favor of employing deferential business judgment rule review in almost all cases, consistent with the views enunciated in Cysive and Cox, [510] but that recommendation has received mix reviews.[511]) Put simply, seen against the backdrop of the heightened standards applicable in M\&A transactions and transactions involving self-dealing, the Lynch Doctrine is not exceptional. All these situations require the courts to scrutinize complex facts. [512] The Lynch Doctrine looks relatively rigid only if deferential review is accepted as optimal.[513] But deferential review has not been the accepted approach to controllers' self dealing transactions, despite Cysive's protestations. [514] Cysive is correct that the Lynch Doctrine allows more suits to go forward than would be true under the business judgment rule. This reflects the accepted concern about controllers' potential for opportunism.

Returning to specifics, Cysive is correct that some duplicative presentation of facts occurs in adjudicating Entire Fairness claims.[515] But its hyperbole to conclude that Entire Fairness review is fatally flawed for this reason.[516] As long as courts are able to impose limits on attorneys' fees 
(which they are), [517] the phenomenon of duplicative presentations of evidence should be manageable for the litigants; it might even be beneficial: facilitating a more considered litigation process in which controllers and minority representatives gradually reassess the merits of settling or litigating further as the many issues in the dispute are resolved serially.

In one glaring example of such hyperbole, Cysive states that Entire Fairness review forces an agglomeration facts and legal issues that is "passing strange."[518] To support this conclusion the court noted that neither the plaintiffs nor the defendant in the case had moved to have the standard of review or burden of proof resolved prior to trial. [519] However, in Cysive, it was the defendant, Carbonell, who requested the expedited full trial, in order to facilitate obtaining financing to consummate the cash-out merger. [520] Hence, it was not unruly, dysfunctional doctrine that forced the full trial forward in Cysive. [521] Rather, it was in the controller's interest to proceed to trial despite the many threshold issues which had not yet been resolved.[522] Nothing about the trial suggests any essential dysfunctionality in the Lynch Doctrine.

\section{The Importance of the Burden of Proof in Freezeout Suits}

In criticizing the Lynch Doctrine for unduly prolonging litigation, Cysive observes that the allocation of the burden of proof is generally of little practical import in these suits. [523] As stated therein: "The practical effect of the Lynch doctrine's burden shift is slight." [524] As a logical next step, the opinion recommends amending the Lynch Doctrine to eliminate burden-shifting upon disinterested consent.[525] Eliminating hearings contesting the allocation of the burden of proof, Cysive contends, will accelerate the resolution of claims against cash-out mergers, and increase controllers' chances of obtaining dismissals. [526] Nevertheless, it's clear from reading between the lines that the court is not recommending that controllers retain the burden of proving the freezeout's fairness.

Furthermore, Cysive describes the allocation of the burden of proof as excessively "time consuming" and "of little practical consequence" [527] because the court portrays merely as a tiebreaker. [528] As stated therein: "[S]hifting the burden of persuasion under a preponderance standard is not a major move, if one assumes, as I do, that the outcome of very few cases hinges on what happens if the evidence is in equipoise." [529] Obviously "dead ties" are unlikely in litigation. If the burden of proof operated only as a tiebreaker, the court would be correct in noting its limited practical importance. But this is far too narrow a reading of the function of burdens of proof in litigation.

In corporate litigation, as elsewhere, the allocation of the burden of proof exerts a comprehensive framing effect on, both the interpretation of the facts and the law. [530] First, it reflects a policy judgment about which party should bear the risk of ambiguity. [531] Under the Lynch Doctrine, and the duty of loyalty in general, the judicial judgment is that the self-dealing fiduciary should bear this burden - a conclusion that is nontrivial.[532] Hence, the Lynch Doctrine's approach to the burden of proof takes account the superior bargaining power of controllers,[533] but creates an incentive for controllers to expose their deals to approval or rejection by independent directors and minority shareholders.[534] The burden-shift as reward also 
encourages candor, since the reward is only available if the controller can prove the consents were fully informed.. [535] Hence there's reason to believe that the burden shifting device under the Lynch Doctrine is far from trivial.

Delaware's case law on corporate fiduciary loyalty also supports this conclusion. Courts oversee something like a "pas de troix" in evaluating the allocation of the burden of proof in cases of alleged loyalty breaches. [536] Once the burden-possessing plaintiff demonstrates that self dealing is present, the defendant (the proponent of the self-dealing transaction) has the burden to prove its inherent fairness -- unless it had obtained disinterested, informed director or shareholder consent. If it did, then once again the plaintiffs have the burden to prove the transactions' unfairness. [537] Were there a broad consensus that the allocation of the burden of proof was of little importance, this three-part framework would not persist. [538]

Evidence of the real, acknowledged importance of the allocation of the burden of proof is also provided by the fact that controllers (and other corporate, fiduciary defendants) go to considerable lengths to obtain disinterested consent.[539] Controllers commonly seek such consent in freezeouts, moreover, although under the Lynch Doctrine, the maximum legal benefit they can obtain is a favorable burden shift (rather than a return to the business judgment rule). [540] If they did not believe that it mattered whether they or the plaintiffs had the burden of proof, controllers would not bother in this regard.

Authoritative legal commentators also affirm the practical importance of the allocation of the burden of proof. For example, in a retrospective of Delaware supreme court decisions (published in 2005), former Delaware Chief Justice E. Norman Veasey stated that “... burdens [of proof] and standards of review are often outcome determinative." [541] Part VII describes in detail this Article's conclusions about the burden of proof in freezeout doctrine: that Dual Ratification should shift the burden of proving unfairness to the plaintiffs. [542]

\section{ENTIRE FAIRNESS AND MOTIONS TO DISMISS}

Setting aside Cysive's policy conclusion that claims should be dismissed on the pleadings whenever possible - it's an exaggeration to conclude that Lynch's adherence to the Entire Fairness standard precludes courts from dismissing nonmeritorious claims against cash-out mergers at the pleadings phase.[543] Cysive seems to conclude the complex factual underlay of cash-out merger cases precludes their being dismissed without a full trial. However, facts can come before the court, without a trial, on documentary evidence and affidavits; and in cash-out mergers and tender offers, the controller would have presented extensive, detailed information about the freezeout in its mandatory SEC filings.[544] This information could be to the court part of the complaint or in a motion for summary judgment. [545] If controllers provide the comprehensive disclosures required by federal law, many freezeout claims should be resolvable prior to a full trial.

In Cysive there were no such disclosures because the defendant requested the expedited trial before they were required.[546] Even still, there was documentary evidence that a genuinely 
independent special committee had actively and effectively negotiated with the controller. [547] It was undisputed that Carbonell allowed the committee freedom to continue searching for a third party buyer. [548] The record showed that the special committee had twenty-one meetings, contacted thirty-seven potential buyers, and obtained valuation analyses from two different wellknown, independent financial advisers. [549] The committee had negotiated a decrease in Carbonell's requested termination fee, had refused his preliminary bids, and had denied his request to cut off third party offers. [550] There were no disputes about these facts.[551] Furthermore, going forward, the objective independence criteria for boards endorsed by the NYSE and the NASD should facilitate courts' determinations about committee independence. [552] In sum, in many freezeouts, there will be dependable, objective or documentary evidence which will help the court to resolve the burden of proof issue early on. [553]

Furthermore, there is reason to be skeptical of Cysive's contention that Entire Fairness review imports an unparalleled level of complexity into corporate litigation. It simply seems implausible that Entire Fairness review in freezeouts is meaningfully more complex than are other corporate legal doctrines, or other features of modern civil litigation. [554] The more reasonable likelihood is that neither freezeout transactions nor the doctrines governing them are more complex, on average, than other forms of M\&A transactions and the fiduciary standards applicable to them. [555] Because the Delaware courts commonly resolve highly complex, fact-intensive disputes in corporate transactions on motions to dismiss and motions for summary judgment, it is reasonable to believe that they can do so efficaciously while adhering to the Lynch Doctrine. [556] That claims under Lynch's Entire Fairness standard commonly go forward, is most likely indicative of judges' perception of widespread overreaching by controllers - and not their helplessness in the face of the Lynch Doctrine. [557]

\section{B. The Cox Decision as An Advisory OpINion}

The next sections of this Part IV provide an analysis of the Cox opinion's criticisms of litigation under the Lynch Doctrine. [558] In many respects, these criticisms expand on those in Cysive, analyzed above.

\section{The Cash-Out Merger in Cox}

The cash-out merger in Cox exemplifies many features of modern freezeout transactions. The Cox family proposed a buyout of the public shares in Cox Communications, Inc, a company in the broadband communications industry that had listed minority shares on the New York Stock Exchange. The controlling family had previously taken the company public, and then private, and then public again, consistent with its self interest and the company's need for capital. [559] When the family announced its freezeout bid in the fall of 2004, it held 74\% of Cox's voting stock and control over the chairmanship of the board. [560] Hence, the Cox family was unequivocally a controlling shareholder as defined under the Lynch Doctrine.

The Cox family's initial \$32 bid represented only a 14\% premium over the average trading

price of the listed shares. The final price, which was agreed to both by the special committee and 
counsel for the minority shareholders, was only slightly better -- \$34.75. [561] Consistent with the minority's best interests, the family agreed to go forward only if it reached an agreement with the special committee. [562] The family also agreed to abandon the freezeout if the special committee was unable to obtain a fairness opinion from its financial adviser. [563] Less favorably for the minority, the family announced its unwillingness to allow a market check or sale of the company to a third party. [564] This limited the committee's and its financial adviser's ability to evaluate the company's true going concern value, hence the actual merits of the controller's offer.

Consistent with the established transactional choreography for cash-out mergers, the special committee hired independent legal advisers (Fried, Frank, Harris, Shriver \& Jacobson LLP) and independent financial advisers (Goldman Sachs). [565] Once the controller and the special committee arrived at final terms, the merger agreement was ratified by the company's full board. [566] The Cox family then made a tender offer for the minority's shares to accelerate the closing of the freezeout and minimize its exposure to appraisal proceedings. After acquiring over $90 \%$ of Cox Communications' shares in the tender offer, the family consummated the freezeout through a short-form merger. [567] The Stipulation of Settlement reflecting the resolution of claims against the freezeout was presented to the Delaware Court of Chancery a month prior to the closing. [568]

\section{A Plan for Comprehensive Doctrinal Reform for Freezeouts}

In Cox, neither the reasonableness of the price offered nor the issue of fair dealings was before the court. [569] The sole contested issue was the fee the controller had agreed to pay the plaintiff lawyers. [570] In Cox, the court used the fee issue as a platform to review Delaware freezeout doctrine and propose comprehensive reform.

From the outset of the Cox opinion, the court's negative view of the conduct of the plaintiffs' lawyers in the transaction is explicit. In one of its blander criticisms, the court described the lawyers as having filed "premature, hastily-drafted makeweight complaints." [571] Moreover, the court expresses a palpable aversion to the conduct of plaintiffs' lawyers in claims filed under the Lynch doctrine: [572] objecting to what it perceives as a nearly comprehensive pattern of abuse in suits and settlements in cash-out mergers governed by the Lynch Doctrine. [573] The opinion describes settlements in cash-out merger freezeouts as unfolding in a triangulated interchange between controllers, special committees and lawyers for minority shareholders. [574] Cox contends that these settlement negotiations are deeply problematic and also paradigmatic in suits filed under the Lynch Doctrine; [575] that they represent an easy and unfair way for plaintiff lawyers to earn fees from controller/defendants. [576] The specter of "free riding” plaintiffs' lawyers [577] clogging Delaware's dockets with meritless claims [578] fuels the court's sweeping invective against Lynch's adherence to the Entire Fairness standard. Accordingly, Cox calls for comprehensive reform: for reforming not only freezeout doctrine governing cash-out mergers, but all Delaware freezeout doctrine. [579] In specific, Cox proposes that the business judgment rule should apply as the presumptive standard of review in all freezeouts, [580] so long as neither the target directors nor a majority of the minority shares disapproved of the bid.[581] This law reform proposal is the culmination of Vice Chancellor Strine's opinions in Pure, Cysive, and Cox. As applied, it would largely repeal the Entire Fairness standard in freezeouts. [582] 
Notwithstanding the comprehensiveness of the reforms proposed in Cox, the "emergency" that "compels" their adoption relates only to one category of freezeouts (cash-out mergers), and one category of cash-out mergers -- those announced as negotiable transactions. [583] At different points in the Cox opinion the court acknowledged this. That is, it acknowledges that the abusive pattern of settlements that drives its critique appears only in cash-out merger freezeouts announced as negotiable deals.[584] In these other transactional settings, Cox notes, the purportedly abusive pattern of hastily filed complaints and collusive settlements does not appear. [585] This limited problem would not seem to require the "fix" of applying the business judgment rule to freezeouts.

Instead confining itself to the fee dispute before the court, Cox engages in a tirade against the "perverse incentives" generated by review for Entire Fairness under the Lynch Doctrine, and presents a wide array of arguments why review for Entire Fairness in freezeouts should be limited. [586] The over breadth in Cox's criticisms of review for Entire Fairness illuminates that the court's objections and reforms are fueled by its policy agenda and preference for limiting freezeout litigation and facilitating freezeout transactions. [587] In Cox the court is not shy about making these preferences explicit.[588]

But were Cox correct that controllers face "injurious" circumstances in proceeding with such freezeouts, then, rationally, controllers would simply eschew announcing the freezeouts as negotiable cash-out mergers. They would plan to acquire the minority stake tender offer freezeouts (where loose fiduciary constraints have operated) or through cash-out mergers publicized only after a contract had been entered into. That controllers continue to make public announcement of negotiable cash-out mergers, suggests that they are not "victims" of ruthless plaintiff lawyers, but rather that they enjoy some net benefit in so proceeding. The most likely benefit would be controller/defendants' achievement of comprehensive, early settlement of litigation against the transactions, as facilitated by the United States Supreme Court's holding in Matsushita Electric Industrial Co. v. Epstein (as discussed further below). [589] Although Cox acknowledges that there might be some benefit to controllers of these "early" settlements, [590] the court focuses almost exclusively on the idea that Entire Fairness review unfairly penalizes controllers and benefits plaintiffs' lawyers,[591] producing meritless “Lynch litigation,” [592] and harming companies and the economy in general. [593]

In essence, in Cox the court of chancery seized on the review of the settlement and fee dispute in the Cox freezeout to present a comprehensive and controversial plan for revising freezeout doctrine to accommodate lesser scrutiny. [594] Reviews of settlements have spurred such wideranging, influential opinions from the Delaware court of chancery in other instances (most notably in Caremark, for example). [595] If the court of chancery had stuck to the issue before it, and merely applied the relevant fee doctrine, it would not have had the opportunity to advocate in favor of lesser review for freezeouts.

\section{COX's CRITICISMS OF THE ENTIRE FAIRNESS STANDARD FOR FREEZEOUTS}




\section{Motions to Dismiss under the Lynch Doctrine, Again}

Cox claims the Lynch Doctrine prevents even meritless suits against cash-out mergers from being dismissed. [596] At several junctures [597] the court opines that the Lynch Doctrine "makes it impossible for a controller ever to structure a transaction in a manner that will enable it to obtain dismissal of a complaint challenging the transaction.” [598] Elsewhere the court observes that it is "an undeniable reality that Lynch stated that any merger with a controlling stockholder, however structured, was subject to a fairness review." [599] To add emphasis the court hypothesized that even if a controller offered a $25 \%$ premium above the market price, negotiated with a special committee of perfectly wise and independent directors ("Bill Gates and Warren Buffett"), and otherwise meticulously supported minorities' free choice in the cash-out merger, its motion to dismiss would be denied. [600] The hypothetical is offered up as "proof” that the Lynch Doctrine is fatally inefficient and dysfunctional.[601] .

\section{a. Are Claims under Entire Fairness Nondismissable?}

In its Cox opinion, the court states that even "premature, hastily-drafted, makeweight" complaints cannot be dismissed under Lynch's Entire Fairness standard. [602] Consequently, perceiving this, plaintiff lawyers file meritless cases against freezeouts and obtain "sizable" fees.[603] Controllers agree to the fees (as part of settlements), Cox contends, to avoid further litigation costs, including discovery costs.[604] The plaintiff lawyers attempt to justify their fee to the court by pointing to the increased price won by the committee in its negotiations; but Cox insists that the commencement of these suits contributes little or nothing to improving prices for minorities. The opinion attempts to support this conclusion in its analysis of the available empirical evidence, but the evidence is too unwieldy.[605] As an alternative support for its conclusion, the court declared that it had not been presented even with one instance of plaintiffs soldiering forward with their suit after the special committee had agreed to terms with the controller. (This is referred to herein as the "Simultaneous Settlement" phenomenon.) Though this Simultaneous Settlement phenomenon might mean many things, the opinion treats it as proof of the inherent corruption driving these suits. [607]

Finally, according to the court, the harms arising from Lynch's rigid insistence on Entire Fairness go beyond the payment of excess attorneys' fees. Rather, Cox contends that the Lynch Doctrine is undermining Delaware's system of representative litigation and impairing economic efficiency (by frustrating otherwise profitable freezeouts).[608] As stated by the court, the Entire Fairness standard is deterring "the procession of offers that provide valuable liquidity to minority shareholders and efficiency for the economy in general." [609] These assertions form the basis of the court's proposal for adopting business judgment deference in freezeouts upon Deferential Dual Ratification.[610]-[611]

\section{b. Entire Fairness and "Mere" Valuation Disputes}

In Cox the court contends that a plaintiff can avoid dismissal simply by disputing the price offered in the cash-out merger. The court correctly observes that "financial fairness is a 
debatable issue." [612] But this does not mean that alleging financial fairness is an open door to the courthouse. On this point, the court has misread the relevant precedents. As provided in Weinberger, [614] and also in Rabkin v. Philip A. Hunt Chemical Corp., [615] without a credible claim of unfair dealing, a plaintiff cannot go forward with an Entire Fairness claim. Weinberger expressly held that without a credible unfair dealing claim, minority shareholders would be relegated to an appraisal remedy. [616] In Rabkin the supreme court affirmed the same rule. [617] The case is widely cited for affirming that appraisal is not the sole remedy for aggrieved shareholders where unfair dealings in a cash-out merger is alleged. [618] But Rabkin's also held that without a fair dealing claim - in a "mere" valuation dispute - appraisal would be the sole avenue for redress.[619] [620] Hence, the fair price aspect of the Entire Fairness standard does not provide minorities, or their lawyers, an open invitation to proceed to discovery. Rabkin also addressed the possibility that plaintiff lawyers would add a "mere allegation" of unfair dealing to their complaints, in order to proceed in equity. In response the supreme court defended that "... our courts are not without a degree of sophistication in such matters."[621]

\section{c. How Controllers Benefit from Early Settlements}

Cox's core objection to the Lynch Doctrine is that even specious claims against freezeouts result in plaintiff lawyers obtaining fees and controllers suffering needless expense.[622] The court gives only momentary consideration to the fact that controllers can benefit from "early," comprehensive settlements of freezeout claims in state court.[623] These benefits come into view upon reviewing the United States Supreme Court's 1996 holding in Matsushita Electric Industrial Co., Ltd. v. Epstein, [624] which held that the federal courts must extend full faith and credit to state court settlements - including settlements of federal securities law claims. [625] Congress had provided for exclusive jurisdiction of Exchange Act claims in the federal courts. [626] This would include federal securities fraud claims involving controllers' merger proxies [627] and tender offer statements, of course. [628] But after Matsushita, litigating and settling in the state courts may preclude further litigation of claims arising from the same transaction. [629] Hence Matsushita's holding is critically important to controllers' decision-making about settling fiduciary claims in freezeouts. As Professor Richard Painter has observed, "Matsushita ... makes state court class actions advantageous for defendants who can settle state fiduciary duty and federal securities claims together in state court.” [630]

There are particular reasons why controllers might prefer to settle in state corporate law proceedings.[631] Apparently, larger settlements and attorneys' fees are paid by defendants in federal securities class actions, relatively speaking.[632] In addition, if defendants obtain disinterested ratification of the freezeout, as provided under the Lynch Doctrine, they are in a highly favorable position vis a vis judicial review. [633] There are also substantial benefits for individual directors defendants of going with the fiduciary/state proceedings. Charter exculpation [634] and corporate indemnification rights [635] would help shield the defendant directors from damages -- even if they were held grossly negligent. Neither shield would be relevant in federal securities fraud suits, however. [636]

The costs and benefits of settling early look very different once Matsushita is part of the 
equation. Certainly, further empirical research is required. But it's entirely plausible that such global settlements of Entire Fairness suits in state court afford controllers a "cheap" way to dispose of fiduciary breach and securities fraud claims against freezeouts.

\section{d. Dismissals under Revlon versus Lynch}

As further proof of Lynch's dysfunctionality, the Cox opinion points to different dismissal rates in claims under Lynch and Revlon. [637] The opinion asserts that courts routinely dismiss nonmeritorious Revlon claims, [638] but cannot ever dismiss nonmeritorious Entire Fairness claims under Lynch. [639] As stated therein: "Unlike any other transaction one can imagine -even a Revlon deal, it was impossible after Lynch to structure a merger with a controlling stockholder in a way that permitted the defendants to obtain a dismissal of the case on the pleadings.”[640] [641]

However, there are legitimate reasons why judges would be less inclined to dismiss Entire Fairness claims under Lynch, than Revlon claims disputing sales of control. First, Cox is correct that there are some parallels between these suits. They involve similarly complex facts, contextspecific and nuanced fiduciary mandates, and terrifically high financial stakes in most instances. They involve a similar admixture of substantive economic issues (e.g. "fair price" and "best price reasonably available") and process-based safeguards ("best efforts," "good faith" and "fair dealings”). [642] But there are crucial differences. Revlon claims (involving sales of control) only rarely present problems of self-dealing corporate fiduciaries, [643] whereas claims against controllers in freezeouts always do, by definition. Revlon duties are more analogous to heightened duties of care (as they relate to target directors); [644] whereas Lynch claims are a variation of the duty of loyalty - the cornerstone concept of corporate fiduciary law. [645]

Revlon claims arise in sales of control, where absent egregious conduct, market forces should provide some meaningful protection for shareholders, [646] but this is not often the case in freezeouts. [647] The Lynch Doctrine's insistence on strict scrutiny reflects this fact - that controllers can stifle the operation of market forces which might otherwise benefit minorities.

Finally, individual directors (on special takeover committees) are most often the defendants in Revlon claims; whereas controllers are more commonly corporate entities. Delaware corporate law is loathe to hold individual, nonmanagement directors personally liable in the absence of egregious self dealing or bad faith (which, again, are rarely relevant in Revlon cases). [648] This policy disfavoring personal director liability would favor dismissals in Revlon cases, but would be mostly irrelevant in claim under Lynch. Hence there are several principled reasons why the courts would be more inclined to dismiss Revlon claims.

\section{Attorneys' Fees in Settlements under the Lynch Doctrine}

The assertion that plaintiff lawyers are gaming flaws in the Lynch Doctrine is at the heart of the Cox opinion.[649] As stated in therein, the "incentive system that Lynch created for plaintiffs' lawyers is its most problematic feature.”[650] The court also asserts that the pattern of settlements 
and fees in freezeouts is so out of control that it warrants scrapping the Lynch Doctrine. However, if excessive plaintiff lawyers fees are the problem, this problem should be and can be directly addressed, without overhauling freezeout doctrine.

Indeed, it is difficult to understand how or why excessive plaintiff attorney's fees could have become a major problem in Delaware class actions, as Cox suggests. The court of chancery must review all settlements in such class actions. Hence the court has legal authority and ample opportunity to reduce the size of plaintiffs' attorneys' fee awards in these suits. The Cox opinion itself states that "this court had been modest in awarding fees in [the class action] context."[651] [652] Indeed, in Cox itself the court determined substantially to reduce the size of the fee payable to the plaintiff attorneys.[653]

It also exercised its authority to alter the fee doctrine relevant to freezeouts. In Cox the court noted its discretion to apply either the Chrysler Corp. v. Dann standards [654] or the more traditional Sugarland standards.[655] The court held that "complaints challenging fully negotiable, all cash, all shares merger proposals by controlling shareholders are not meritorious when filed under the Chrysler Corp. v. Dann standard.” [656] It further provided that going forward "no risk premium should be awarded in fee applications in cases ... when a plaintiff suing on a proposal settles at the same level as the special committee." [657] Finally, Cox held that if a controller and a special committee agreed to final terms in the freezeout, without including the plaintiff lawyers in their negotiations, there should be "no presumed entitlement to a fee by the plaintiffs' lawyers." [658] In these "moves," Cox has extended the transactional choreography for cash-out mergers to encompass the conduct of plaintiffs' lawyers, and has significantly limited their potential to earn fees from collusive settlements.

The court also deftly resolved the fee dispute before it. It approved a fee award of \$1.275 million, instead of the $\$ 4.95$ million fee the controller had agreed to pay.[659] Interestingly, the settlement had not contemplated that the lawyers' fees would reduce the price obtained for the minority.[660] In essence, the court was not ruling in the minorities' interests but rather acting as a gatekeeper of the litigation system in altering fee doctrine and reducing the fee agreed to. [661] In this sense the case demonstrates the courts' ability to redress litigation agency costs - rather than their helplessness.

Furthermore, the Cox opinion demonstrates that fee issue are fundamentally severable from doctrinal issues inherent in applying Entire Fairness in freezeouts. The portion of the Cox decision interpreting Chrysler v. Dann [662] and the Sugarland factors [663] is severable from the opinion's condemnation of Entire Fairness review under Lynch. [664]

In addition, recent empirical data on fees in acquisition-oriented class actions, presented by Professors Thompson and Thomas in a Vanderbilt Law Review article published in 2004, conflicts with Cox's assertions about the gravity of the fee problem in Entire Fairness claims against cash-out mergers. [665] Although they acknowledge the need for further research, [666] these professors conclude that plaintiffs' lawyers' fees in Entire Fairness claims under Lynch are relatively modest in amount. [667] The relatively modest nature of these fees becomes evident in 
comparison to the fees awarded in the settlement of federal securities class actions, for example. [668] This modest nature of the fees paid to plaintiffs' lawyers in freezeouts holds true whether they are considered on a percentage of recovery basis, [669] or on an hourly basis. [670] Just as significantly, Thompson and Thomas illuminate the genuinely contingent nature of plaintiff lawyers' receipt of any fees in freezeouts (and other acquisition-oriented class actions). [671] With respect to freezeouts, Thompson and Thomas' data suggests that plaintiff lawyers receive fees in less than forty percent of all the cases filed. [672] Their data contrasts with Cox's assertion that plaintiffs' lawyers can earn "sizable fees" [673] merely by filing a claim under Lynch. [674] Ultimately, even Cox itself (after excoriating the conduct of plaintiffs' lawyers in cash-out mergers) observes that plaintiff lawyers have "moderated" the size of their fee requests in this setting in recognition of the court of chancery's supervisory role.[675]. In sum, the existing empirical evidence does not suggest that the plaintiff attorneys fees problem in freezeouts is a substantial one. Most significantly, as illustrated in Cox itself, the Delaware court of chancery has discretionary authority and ample opportunity to block the payment of excessive fees in the course of reviewing settlements.

\section{Litigation Commenced During Freezeout Negotiations}

At the heart of the Cox opinion is the question of whether Entire Fairness suits add value for minorities when they are filed while negotiations are pending.[676] The expert for the plaintiffs' lawyers, Guhan Subramanian, testified that the pendency of the lawsuit was a positive factor influencing the benefits obtained for the minority -- so that the plaintiffs' lawyers had earned their fee. [677] The court attempted to resolve this particular question, but also the broader one of whether early filed claims ordinarily provide leverage to minorities in freezeout negotiations.[678] On this latter issue, it held that the filing of claims adds little or no value for minorities - that the minority's representatives will do just as well without the leverage of litigation having commenced. [679] Furthermore, according to Cox, if the committee and a majority of the minority shares approve the offer, that should be sufficient showing of its fairness to obviate judicial review of the merits.[680] [681]

In Cox the court wrestled with contradictory econometric evidence presented by experts for both sides. [682] In the end, it arrived at the most intelligent answer possible: that at present it is not empirically possible to prove what portion of an improved price is attributable to litigation having been commenced. The existing empirical evidence seems too incomplete.[683] But the court nevertheless had to resolve the fee dispute before it - hence seemed to be called upon to rule on whether the plaintiff lawyers had earned their fee from filing the litigation.[684] In effect, the decision "split the difference" - awarding some fee to the plaintiff lawyers, but far less than they'd hoped.[685]

On the general issue of the value of Entire Fairness suits filed during negotiations, the court ruled that they are presumptively "nonmeritorious.” [686] Leaving aside the quantitative evidence, the court pointed to the "Simultaneous Settlement" phenomenon. [687] But it's not self evident that this proves early filings do not benefit minorities. Many factors are probably at work in the Simultaneous Settlement phenomenon. [688] [689] Indeed, even Cox admits that the application of 
the Entire Fairness standard -- even, perhaps, the pendency of the litigation -- gives special committees "some” slightly increased leverage in bargaining with controllers in freezeout. [690]

Perhaps most importantly, in Cox the court contends that these lawsuits do not add value because committees (it asserts) have the power just to say "no" to controllers.[691] However, despite the court's assertion, the committee's disapproval will not prevent the controller from proceeding with a freezeout. [692] Given the terms of the merger statute and the option of pursuing a tender offer freezeout, the controller can go around a disapproving committee and effectuate a freezeout if it so chooses.[693] The committee's disapproval may alter the controller's tactics or its willingness to go proceed, but this “no” is not a deal killer. [694]

Finally, Cox concludes that the commencement of Entire Fairness suits during negotiations does not add value because "there is no litigation conflict." [695] But even if there are no actual hearings or other judicial proceedings, this does not mean these filings accomplish nothing. For instance, no one disputes that poison pills are effective anti-takeover devices, despite the fact that they are never triggered. Poison pills, like early claims in freezeouts, signal the availability of an immediate response to an unfair acquisition. Once a claim is filed, if the controller engages in unfair dealings, there can be an immediate judicial response: this the controller and its lawyers know. Furthermore, if Cox is correct that there is "no actual litigation conflict," then the litigation agency costs that arise from these filings cannot be overwhelming.[696]

In addition, the filing of claims upon the commencement of cash-out mergers allows time for the minorities' lawyers to resolve who will be lead counsel and lead plaintiff. [697] Since these (federally inspired) mechanisms have been adopted by the Delaware courts to promote efficient litigation, it makes sense to allow the plaintiff lawyers time to implement them.

In sum, neither the existing empirical evidence, nor the simultaneous settlement phenomenon makes a persuasive case for early filings under Lynch being wasteful or unproductive.

\section{The Utility of Discovery}

Cox portrays discovery requests under the Lynch Doctrine as mere tools to extort settlements from controllers. [698] Of course, discovery requests could be abused, as was recognized by the PSLRA's stay of discovery provision. [699] However, once again, the court of chancery has the ability to limit discovery in freezeout litigation in order to prevent abuse. [700]

In addition, the legitimacy of discovery should be acknowledged. Special committees and minority shareholders may legitimately need additional information about the freezeout offer. As a general matter, the Lynch Doctrine reflects the systemic informational asymmetry between controllers and minorities. Controllers are the ultimate "insiders;" minorities and the outside directors representing them do not have informational parity with respect to the company's prospects. So long as there is appropriate judicial supervision, the discovery process can be viewed as a legitimate extension of the "arms' length," fair dealing process mandated by Weinberger. [701] In effect, it is an alternative form of the due diligence process conducted on 
behalf of minorities in freezeouts. [702]

The peculiar situation of outside directors is also relevant to the need for discovery. Outside directors have less information than management or the controller; and yet outside directors are chosen to represent minorities in negotiating with controllers on the assumption that they will not be beholden to the controller. [703] Furthermore, consistent with Lynch's concern about inherent coercion, the special committee directors may be fearful of engaging in a full scale due diligence process as part of their negotiations with the controller. Cox itself notes that outside directors are likely to have limited time, expertise or face other practical impediments that hinder their advocacy on the part of minorities.[704] The discovery process may contribute a vital counterbalance to what the outside directors could learn on their own.

\section{Suits Against Target Directors During Negotiations}

Individual target company directors are commonly included as defendants in freezeout litigation.[705] However, because the Entire Fairness standard elaborated under Weinberger and Lynch (and their progeny) does not specifically address target director liability in freezeouts,[706] claims against target directors would commonly be brought as pendant (supplemental) claims under the Lynch Doctrine. To be precise, they would be plead as duty of care or potentially breach of good faith claims in most instances. Target directors would almost never be held personally liable in a freezeout, but the potential for financial liability is not the only stimulus influencing their conduct. Even if the target directors are not named as defendants, they are commonly called upon to give testimony in Entire Fairness litigation in freezeouts. Without the Entire Fairness claims, the good faith and duty of care claims would probably be summarily dismissed [707] But for purposes of this discussion, the important point is that the pendant claims (filed during negotiations) are likely to catalyze the special committee directors to exert their best efforts in negotiating against the controller. Despite the low minimal chance of financial liability, the outside directors will wish to avoid the potential for embarrassment amongst their peer group. Indeed, Delaware fiduciary opinions often consciously take advantage of this "shaming" opportunity to stimulate better conduct on the part of independent directors. [708] Hence, the existence of pendant claims against target directors in freezeouts, or the taking of their testimony in claims filed against controllers, is a further positive attribute of the Lynch Doctrine.

\section{REDUCING LitigATION IN FREEZEOUTS}

\section{The Purported Problem and a Plan}

Cox contends that the Lynch Doctrine invites strike suits because claims cannot be dismissed at the pleadings phase;[709] the thin basis for this assertion was analyzed above. [710] The court also contends that these strike suits are thwarting otherwise value-maximizing freezeouts, although the opinion presents no evidence for this.[711]) The opinion contends that strike suits under Lynch are undermining the integrity of class action litigation in Delaware - despite the court's seeming ability to control discovery abuse and excessive plaintiff attorney fees.[712] Cox's contends that 
Lynch should be "eased," so that business judgment deference would apply upon Dual Ratification,[713] although this would be more like a repeal than an "easing” of the Lynch Doctrine. Despite the fact that heightened review is more the rule than the exception in high stakes M\&A transactions, the court insists that its "modest" [714] and "sensible" [715] plan to implement business judgment deference in freezeouts will bring this doctrine into "harmony with the rest of Delaware corporate law," [716] and increase investors' faith in the "integrity" of Delaware's corporate jurisprudence.[717] According to the court, so long as there has been Dual Ratification,[718] allowing business judgment deference in freezeouts would not "diminish the integrity-enforcing potential of litigation in any material way." [719] In short, the court's enthusiasm for curtailing strict scrutiny in freezeouts is unqualified.

Reading between the lines, it's apparent that the court anticipates that most freezeouts would receive Dual Ratification.[720] If this were not true, the reforms proposed in Cox would not have their intended effect of reducing litigation in freezeouts. On this point the court is likely correct. The fundamental insight under Lynch - that inherent coercion operates in freezeouts - suggests this would be true.[721] And as discussed further in Part VI, Pure affirms the continued relevance of inherent coercion in both freezeout formats. And Cox does not disprove it, but merely disparages it.[722] Furthermore, the likelihood of controllers obtaining Dual Ratification is increased by the effect the Cox Reforms would have on the fair price duty. As described in Part $\mathrm{V}$, below, the Cox reforms would marginalize the operation of the fair price duty during the pendency of negotiations. In the absence of controllers having a fair price duty, their representatives have far less leverage to say "no" to controllers.[723]

As future courts consider whether to endorse Cox's Dual Ratification scheme, they should be wary of many of the claims made in Cysive, Pure and Cox. Most glaringly, the Dual Ratification proposal is not a "modest" [724] adjustment to Lynch Doctrine. [725] The court of chancery's proposed reforms cannot truly be reconciled with Weinberger and Lynch.[726] So the real question is whether the court of chancery will find a way around these precedents, and whether the supreme court would (have occasion to) intervene, and speak to the continued importance of Entire Fairness for freezeouts, if it did.

\section{Will the Quality of Consents Be Reviewable?}

The goal endorsed most fervently in Cox is limiting litigation in freezeouts. However, even if the Cox reforms are followed - so that business judgment deference applies upon Dual Ratification -- it's not clear that this would be the result. Much of the result would depend on the approach the court took to the consent, i.e. Dual Ratification.

Under such a new framework, the consents (Dual Ratification) become dispositive of the standard of review. This presents a paradox, however, as Cysive intuited. Surely the quality of the consents must matter: whether they are fully informed, freely given and sufficiently numerous. But once these questions are before the court, the opportunity to avoid judicial scrutiny is limited. Aspects of "fair dealings" are already subject to review.[727] Or -- if the quality of the consents would not be scrutinized, then we should be clear that freezeouts will 
have been deregulated. Equity will have resigned its role in this setting. Thus an easy accommodation between the Lynch Doctrine and the Cox Reforms is illusory. As a matter of policy, the courts may decide to apply the business judgment rule to freezeouts, but they cannot do so, legitimately, while claiming that they have not radically diminished the role of equity in protecting minorities in freezeouts. [728]

\section{The Likelihood of Increased Appraisals}

Even if equitable claims against controllers in freezeouts are reduced, this might not affect the overall incidence of claims filed against freezeouts. Most obviously, there would be a net increase in appraisal actions.[729] After Weinberger, the equitable cause of action became a preferable format for aggrieved minority shareholders to contest cash-out mergers. [730] However, if the business judgment rule becomes the base line standard for freezeouts, this would substantially curtail the filing of equitable claims and increase the filing of appraisal actions. The court of chancery's would still be involved in complex valuation litigation against freezeouts.[731]

Furthermore, there is a substantial likelihood that curtailment of the equitable action would trigger reform of the appraisal statute to make it more available to aggrieved shareholders. The decision in Glassman certainly increased the pressure on the Delaware legislature to give further attention to appraisal reform.[732] And there has been increased academic commentary calling for liberalizing and rationalizing the appraisal remedy. [733] Although many academics have endorsed the construct of deferential review upon Dual Ratification, many others have not yet awakened to the controversy, and may not be inclined to jettison strict scrutiny.[734] Furthermore, as had been true in the 1970s, shareholder advocates are likely to take their concerns public - particularly if the current low stock price valuations invite a wave of freezeouts - and pressure legislatures to expand the appraisal remedy. Hence, if the Cox Reforms are followed, the net increase in appraisal actions may "trump" the reduction in equitable cases.

\section{More Claims Against Target Directors?}

In Cox the court professes that its Dual Ratification proposal would not "diminish the integrityenforcing potential of litigation in any material way." [735] Similarly, it contends that shareholders would still have "potent litigation weapons" would in shareholders" “arsenal.”[736] Expanding on this concept, the court states that:

[p]laintiffs who believed that a special committee breached its fiduciary duties in agreeing to a merger would continue to have the practical ability to press a claim; they would just have to allege particularized facts demonstrating a breach of fiduciary duty. [737]

The statement is succinct, almost a "throw away," but its implications are startling. The court seems to be proposing that notwithstanding the Cox Reforms, dissatisfied shareholders could bring breach of duty claims directly against the committee directors.[738] Dual Ratification would 
preclude an Entire Fairness attack on a controller's conduct in the freezeout, but minorities could still plead breach of care and breach of good faith claims against the special committee directors. But if this is the important of this passage from Cox, then it, too, undercuts the decision's goal of reducing litigation in freezeout. "Swapping" minority claims against controllers for claims against committee directors would not reduce freezeout litigation. Secondly, the suggestion cuts against the grain of corporate fiduciary duty, which (as stated above) resists holding individual directors liable absent egregious circumstances. [739] Most suits against committee directors would be plead as breaches of care: that the committee was too passive in defending the minorities' interests.(This was the essence of the shareholders' complaint in Solomon, of course.) [740] And with respect to loyalty, even if the directors were found to be dominated by or beholden to the controller, this in itself is not a breach of duty. [741] As stated previously, a variety of legal devices limit or eliminate directors' financial exposure to damages for breach of care. [742] Despite Cox's assertion, it is not likely that shareholders will sue target committee directors in freezeouts; this is not a feasible surrogate for reduced accountability on controllers’ part.

\section{Will Minorities' Approvals Be Used to Exculpate Directors?}

In order to obtain the favorable burden shift under the Lynch Doctrine, controllers most often seek special committee approvals, rather than minority shareholders.'[743] (For one reason, no proxy solicitation is required in seeking the committee's approval, which saves the controller time and expense.) Cox makes hay that the Lynch Doctrine has underserved minorities' interests in failing to require both forms of consent,[744] but the criticism is inapt since the consents under the Lynch Doctrine are relevant only to burden shifting, and not to supplanting judicial oversight. [745]

If Cox's Dual Ratification regime is accepted as the new transactional choreography for freezeouts, defendants will surely seek to have such consents expanded to exculpate committee directors from potential liability. Both controllers and target directors will urge that consent be used as such a waiver. Indeed, this argument has already been presented to the court of chancery in the Emerging Communications litigation. [746] In the case law expanding on Section 144 of the DGCL,[747] valid shareholder ratification has been used as such a waiver of liability in certain allegations of fiduciary breach.[748] This potential for exculpation via ratification is illustrated in the litigation in Smith v. Van Gorkom, [749]Orman v. Cullman, [750] and Harbor Financial Partners $v$. Huizenga, [751] for example. Such shareholder ratification has sometimes been allowed to extend even to breach of loyalty claims, in fact. For this reason, ratification is more useful to target directors than charter exculpation and/or indemnification. [752]

To be clear, there is no express proposal in Cox that minority shareholder consents in freezeouts should be deployed defensively as a tool precluding liability for individual directors. However, the Cox opinion does expressly address the consent-as-ratification case law (arising from DGCL Section 144) with approbation.[753] More broadly, the general favor Cox exhibits towards (seemingly) bargained for results supports this evolution of the significance of shareholder approval in freezeouts. [754] In sum, although Cox expressly describes the majority- 
of-the-minority shareholder ratification process as an additional safeguard of minority shareholders' interests, [755] such consent could easily be judicially expanded to preclude target director liability in freezeouts.

\section{The Evolution of Transactional Choreography for Freezeouts}

The recent freezeout cases represent the suits filed against these transactions as a deadweight loss for the judicial system, investors and the economy.[756] But the court of chancery has not given due consideration to the positive benefits arising from Entire Fairness review in freezeouts. In particular, such judicial has produced a detailed, current set of best practices (transactional choreography) that benefits minorities and may helpfully guide controllers in future freezeouts. If the Cox Reforms are followed, so that business judgment deference becomes the base line standard for freezeouts, far fewer freezeouts would be reviewed. The court would have less opportunity to keep this transactional choreography current. (Much would depend on the court's interpretation of its role in reviewing motions to dismiss and the quality of the consents.). Curtailing the transactional choreography for freezeouts would be a net loss for investors and the economy - one which is not acknowledged in the recent cases.

\section{After Cox: Bargaining in the Shadow of a Limited Fair Price Duty}

Between the duty to deal fairly and the duty to pay a fair price, the latter has been far more controversial.[757] This is evident in the difference between the Lynch Doctrine and Solomon on the fair price issue. The difference is absolute: Lynch says “yes,” [758] Solomon says "no.” [759] Achieving a resolution to whether there should be a fair price duty in freezeouts represents the greatest stumbling block to unifying this body of doctrine.

Perhaps because Lynch and Solomon are contradictory and mutually exclusive on the fair price question - and because a stated objective of the recent cases is to unify freezeout doctrine -- the court of chancery largely avoids the issue in its proposed reforms. This is true even in Cox. Nowhere in Cox does the court of chancery take a clear position on what would happen to the fair price duty in a Dual Ratification world. [760] It is clear, however, that the court favors the Solomon approach (where no fair price duty applies) over the Lynch Doctrine. [761] In the Cox decision - which is again the most telling recent treatment of the issue - the fair price issue is subsumed into the discussion of Dual Ratification, as further analyzed below.

\section{A. The Fair Price Duty and Negotiations}

As a preface to analyzing what the court of chancery's freezeout reforms would mean for the future of the fair price duty, it's necessary to review the role that duty plays in freezeout negotiations. One aspect of the question can be posed as follows: is there much difference between a fair price duty and a fair price remedy? This Article answers "yes;" and this is a major rationale for extending Entire Fairness so that it will apply to all freezeout negotiations.

Part II of this Article described the various legal price regimes relevant to freezeouts. The 
discussion of the problems arising from Solomon's failure to apply a fair price duty to controllers' tender offers are relevant once again here. [762] (So are appraisal's failure to address tender offers.) Without a fair price duty, controllers can employ their overall financial and legal power advantages to depress the value of minorities' shares prior to making lowball tender offer freezeout bid. Hence, they can benefit from pushing the outer limits of the fiduciary doctrine governing controllers' self dealing prior to launching a tender offer freezeout (where no fair price duty applies).[763] To be particular, they can push the hazy outer limits of the corporate opportunity doctrine. They can delay the development of lucrative business ventures. [764] They will gain from withholding dividends. [765] And there are many other "softer" forms of self dealing in cases of controllers compelling contracts with affiliates. In many instances there may be self-dealing by the controller which cannot be remedied through legal proceedings. Controllers can signal to the market that they are willing to exploit their control to obtain these benefits. For many reasons, boards of controlled companies are poorly situated to withstand controller-sponsored, minority-unfriendly initiatives. (Even in a post-SOX world, in listed companies where there is a true controller, it suffices to have only three independent directors on the board.)[766] In sum, in a transactional world devoid of a fair price duty, the controller can take steps to depress the minority stock's trading price and then compel a freezeout to benefit from this depressed price.

What do negotiations at a hypothetical bargaining table look like in the absence of a fair price duty? Stated otherwise, what happens to the "arms' length dealings" construct once there is no fair price duty at the point of negotiations, but merely, first, an expanded prohibition against coercion (consistent with Solomon) and, second, maybe, a chance at going concern value after years of litigation? At this juncture, appraisal is only marginally relevant as a reference point. (To review: the practical impediments and statutory limits discussed earlier are relevant to the back end of a tender offer freezeout and all cash-out mergers; and appraisal isn't even an option in controllers' tender offers.) Without a fair price duty, even in a cash-out merger the controller would have no incentive to offer more than the lowest credible estimate of "fair value" (going concern value), discounted by the impediments and general unwieldiness of appraisals. A rationally maximizing, well advised controller would offer no more. In negotiations, the controller would counter the special committee's request for a higher price with the truism that it would be irrational for it to pay more than it is legally required. The controller will advise the committee to take it (ratify the freezeout) or leave it (leaving the minority with little or no alternative to the probably now more deeply discounted market price).

In this setting - i.e. in the absence of a fair price duty - for those negotiating on the minorities' behalf, virtually any premium to the market price would start to look like an appealing offer. Indeed - in what seems like a remarkable departure from modern financial theory, as well as Delaware's case law on valuation -- the court in Cox observed that minorities are doing "more than tolerably" well because they are selling to controllers in freezeouts at premiums to the public trading price of their shares. [767]) The savvy controller describes its offer as a great deal for the minority shareholders. ("Puffery" is not the basis for a complaint under the federal securities laws. [768]). The announcement of the offer would generate significant publicity and attract arbitrageurs; this would stimulate trading activity, which would further drive a spike in 
the trading price (which would dissipate quickly were the committee to disapprove of the freezeout offer, because it would be construed as a sign the deal might fail). A herding effect operates in these settings: minority shareholders become excited by the prospect of the transaction; the premium over the market price is salient.[769] Unless the offer to the minority is grossly underpriced, the "bird in the hand" rationale begins to obscure the question of whether the price is commensurate with going concern value. And appraisal might not be available, in any event.

Without there being a definitive fair price duty protecting minorities in the negotiations, the special committee is under tremendous pressure not to "kill the deal" by refusing the controller's offer. The premium over the trading price reflected in the controller's offer - indeed, almost any plausible offer from the controller -- becomes the relevant benchmark for the merits of the deal. Absent a fair price duty, the committee has only a very attenuated conceptual framework against which to judge the controller's offer. Rather than some outside shot at going concern value, obtained after years of litigation, the (discounted) market trading price becomes the most available benchmark for measuring the controller's offer. Moreover, without the support of the legal fair price duty, if the committee concludes that the controller's price is inadequate, it will have to scramble to provide a compelling account of why it reached this conclusion. Without a fair price duty, the committee cannot fall back on the gap between the legal "fair price" and the price offered by the controller as the rationale for its disapproval. The legal fair price floor has stopped supporting the committee's negotiating leverage.

If the minority's representatives are well advised (and there's no reason they should not be), the negotiations look very different in the presence of a fair price duty. The fair price duty creates a clear heuristic. It should give the committee the high ground to commence the negotiations. The committee should open by asserting the minority's legal entitlement to a premium to the firm's current going concern value. This positive legal claim yields a normative one: that the controller is legally obligated to pay no less.[770] The fair price duty allows the committee to argue that it cannot consent (consistent with its own fiduciary duties) [771] to a price that is less. If the fair price duty applies and the committee believes the controller's price offers less than a premium to going concern value, the committee has a clear rationale for disapproving of the offer, and explaining why it did so to the minority shareholders. ("The controller refused to pay the price you were entitled to receive under the law.") The committee directors have no incentive to derail the deal, so there is no reason to believe they'd be biased against the controller's offer. The fair price duty frees the committee from the virtually untenable predicament of having to go back to the minority and say "our instinct was that the price was too low." If the controller is offering what its financial advisers believe is a premium to going concern value, the committee can approve of it; if not, they have a firmer footing to reject the offer. And in a world where the fair price duty applies, the committee can provide the minority with a coherent account of why it chose as it did. [772]

\section{B. Cox on the Fair Price Question}

Would a fair price duty apply under the Cox Reforms? Again, in Cox the court does not 
affirmatively address the status of the fair price duty under its unified freezeout doctrine. Nevertheless (as stated earlier), it's apparent that in Cox the court's clear preference is for Solomon over Lynch, which suggests that it does not validate a fair price duty.

Second, based on what's express and what's implied in Cox's Dual Ratification provision, the best answer is that a fair price duty would not apply to freezeouts during negotiations. [773] That is because Cox says that Entire Fairness should not apply unless the committee (or majority of the minority shares) disapproves (i.e. has disapproved) of the offer.[774] Hence, the fair price duty would spring to life only if negotiations had derailed.

Under Lynch, the Entire Fairness standard applies regardless of whether the committee says “yes” or "no." (If it says “yes,” there is a burden shift, but that is all.) Under the Entire Fairness standard, the controller bears the risk of a court determining that the freezeout's price was less than "going concern value plus." Under the Entire Fairness standard, because the fair price duty applies whether or not the committee says "yes" or "no" (or is not consulted at all), the committee's participation can only benefit minority shareholders.

Inviting the committee into the negotiations cannot be used by the controller as a Sword of Damocles to hang over the directors' heads. This is precisely what it would become if the committee directors lack the ammunition of a fair price duty. If the fair price duty springs to life only after the committee (or the majority of minority shares) has said “no," [775] then it won’t inform the committee's price requests. It won't inform the controller's opening bid. In the negotiations, the deeply discounted trading price of the minority block would take the place of expanded going concern value. Certainly, under the Cox Reforms, the fair price duty is not clear enough or stable enough to be of much use to the committee or minority shareholders in their negotiations with the controller.

Cox's proposed shift away from the Entire Fairness standard for freezeouts raises some additional, more technical questions. In a world where Dual Ratification triggers the business judgment rule standard, what happens when the committee takes a position of neutrality? [776] As stated earlier, this would probably become a common occurrence in tender offer freezeouts. And it could become an issue even in cash-out mergers, because it's increasingly apparent that agreements can be written to allow mergers to go to the shareholders even where the board has changed its mind.[777])

Finally, given the importance of independent director/special committee assent under Cox's Dual Ratification provision, what numerical minimums should attach to such director/committee assent? Pure had a special negotiating committee of two: should that be enough? Can it be reasonable to allow deferential review (assuming the minority's assent), if the committee has remained neutral, or if the committee is composed merely of two independent directors? In a committee of three (which may foreseeably become the norm), what if two outside directors consent, and one disapproves?[778] The Delaware supreme court's recent decision in Krasner $v$. Moffett suggests there is reason to be skeptical of such "mini" director consent. [779] (It's noteworthy that until recently, New York had a higher threshold than Delaware's for 
independent director ratification to be deemed effective to cleanse self-dealing.) [780] Because Cox makes the burden of proof hinge upon these consents, these formal, numerical issues raise very important questions.

Based on the discussion above, Cox's promise of reducing litigation under a Dual Ratification standard for freezeouts looks even more unrealistic. The new regime raises too many unresolved issues. In light of these open issues, the parties could not dependably predict, ex ante, whether the Entire Fairness standard or the business judgment rule would apply to the freezeout under the new reforms. That uncertainty would be worse than the formalistic, "two tracks" approach that has been employed up to the present. Compared to this unstable state of affairs, certainly, Lynch's clear affirmation of Entire Fairness in freezeouts is far more beneficial to investors, planners and the markets.[781] Finally, the Dual Ratification approach is facially plausible only if one rejects the most basic assumption underlying Weinberger and Lynch: that is, that the operation of inherent coercion taints consents in freezeouts. But there is no reason to assume the sudden irrelevance of inherent coercion; nothing in the recent opinions suggests this is so.

\section{Empirical Evidence}

There is a growing body of empirical evidence analyzing the premiums paid in freezeouts. These studies analyze the role of legal standards in influencing freezeouts and the incidence and nature of settlements and lawsuits in freezeouts. [782] As mentioned previously, in Cox the court expended considerable energy considering this empirical evidence, and especially the impact alternative freezeout structures, with their different standards of review, on the prices obtained by minorities. [783]

In their research, Professors Thompson and Thomas concluded that suits in cash-out mergers under the Lynch Doctrine raise the premiums offered in the "worst" transactions. [784] Professor Subramanian's data led him to a similar conclusion about suits against cash-out mergers under the Entire Fairness standard. (To be clear: Subramanian served as an expert on behalf of the plaintiffs' lawyers in the Cox settlement.) [785] In contrast, Professors Weiss and White's data led them to conclude that Lynch's Entire Fairness standard has led primarily to increased welfare for plaintiffs' lawyers, but not minority shareholders.[786] In sum, Thompson and Thomas' and Subramanian's conclusions point in the direction of extending the Entire Fairness standard to all forms of freezeouts, [787] consistent with minorities' best interests - a conclusion in line with the reform proposals endorsed herein. In contrast, Professors' Weiss and White's analysis supports limiting the Entire Fairness standard's application, consistent with the Dual Ratification proposal endorsed in Cox. [788] Cox's expressed displeasure with the Lynch Doctrine [789] reflects many features of the scholarly criticisms published by Weiss and White [790] (to be clear, these professors were the principle objectors to the fee disputed in Cox).[791] [792]. [793]

\section{FAIR DEALINGS AND THE CONSENT QUESTION}

\section{A. The Substance of Fair Dealings}


If there were a means to obtain genuine, free consent from the minority shareholders, this would resolve the problems attendant to freezeouts - in essence there would be no "freezeout." The attraction of the idea of consent is apparent even in Weinberger's discussion of fair dealings. As stated therein, if the court found sufficient basis to believe there were vigorous, unrestrained negotiations between the controller and the minorities' disinterested, informed representatives, this would be a strong indicia of fairness; the defendants would likely prevail in the litigation. [794] But Weinberger and Lynch also describe the reasons why truly free, informed consent is a near impossibility in the freezeout context; most pertinently, that the specter of inherent coercion undermines the likelihood of the consents being truly voluntary. Yet the attraction of the consent "construct" is a compelling in corporate law; indeed it drives the court of chancery's Dual Ratification proposal for freezeout reform. The issue of voluntary consent in freezeouts thus warrants further consideration. What motivates the intense concern about freedom of choice for minorities in relation to freezeouts, as embodied within Entire Fairness' fair dealings requirement?

\section{B. Property Law Concerns}

Lynch's Entire Fairness standard represents an attempt to address a fundamental problem of property law that arises in the context of freezeouts. As described earlier, the DGCL affords controllers the power to eliminate shareholders, without their consent, through a cash-out merger.[795] In effect, the controller can compel the sale of the minority's shares. This is very odd from the perspective of property law, even if the minority is compensated at fair value. In effect, controllers' power in cash-out mergers is analogous to the state's power of eminent domain. Of course, the state's power of eminent domain is subject to strict limits, including constitutional ones, and intensive judicial oversight where challenged.[796] The Entire Fairness standard and its oversight by the state courts can be construed as an analog of "due process" as overseen by the federal courts.[797] If the minority truly consented to the freezeout, then there would be no "taking;” the property law problem presented by freezeouts would be neutralized.

\section{Institutional Checks and Balances in Corporate Governance}

Second, freezeouts are in tension with the traditional framework of corporate governance. The Entire Fairness standard is a response to that institutional friction. [798] Once a controller is present, the routine allocation of decisional authority in corporate law is up-ended.[799] It is axiomatic in corporate law that the board of directors has preeminent authority over corporate affairs, and shareholders do not. [800] The idea is so basic and pervasive that it is stated expressly in Cox itself: “... the central idea of Delaware's approach to corporation law is the empowerment of centralized management, in the form of boards of directors and the subordinate officers they choose, to make disinterested business decisions. The business judgment rule exemplifies and animates this idea." [801] It is the board which should set in motion basic changes in corporate affairs, not the officers, and not the shareholders. [802] This centralization of power is defended as maximally efficient.[803] But once there is a controller present, the board's preeminence is severely compromised, by definition. If the controller is an individual, he or she will normally be on the board, and probably as its chairman. Often controllers-as-individuals also serve as senior 
executive officers of the company, most commonly as CEOs. This gives them tremendous de facto authority over corporate affairs. [804] If the controller is a parent company, it will commonly elect officers of the parent company to the controlled company's board.[805] As mentioned earlier, even the listing standards' board independence criteria are relaxed in regard to companies with controlling shareholders. [806]). As noted in the Introduction, the board theoretically owes duties to all shareholders equally, [807] but in practice the controller's interests will shape management's and the board's strategies and range of options. [808]

A freezeout proposal is effectively a corporate governance "showdown." The freezeout proposal originates with the controller, and would not be proposed were it not consistent with the controller's self interest. It does not originate with the board. Reflecting this reality, Weinberger smartly rejected the requirement that the controller prove a corporate-oriented purpose for eliminating the minority, which would effectively be a ruse. [809] Furthermore, while the freezeout effects a fundamental corporate change, based on the DGCL, the minority's votes are useless to stop it. [810] As was the case in the transactions in Pure and Cox, [811] once the controller announces an unwillingness to sell to a third party, the market for corporate control will not operate in the minority's interest. Even assuming a independent negotiating committee is established, without the full board's assent, such a committee would lack legal authority to approve a financial restructuring, or alternative sale transaction. [812]

As reflected in Weinberger, Lynch, and their progeny, the Entire Fairness standard invites the controller to constitute surrogates for the checks and balances which would operate within the system of corporate governance were no controller present. But these cases are mindful that these are merely surrogates. A vote by the majority of the minority or ratification by a facially independent subcommittee of the board is not the same as assent by a wholly independent board, or a majority of all voting shares. Under the Lynch doctrine, accordingly, they constitute "strong evidence," but merely evidence of fairness. They do not obviate the need for judicial vigilance where the deal is contested. The Cox Reforms would expressly change this, consistent with the court's stated objective of facilitating controllers' ability to obtain dismissals on the pleadings.[813] Dual Ratification would mean the parties would be left to their private agreements. The legal institutions of corporate governance, including rules of fiduciary duty, would be supplanted thereby. The paradigm of bargaining and private contract would supplant the paradigm of fiduciary duty.

Nor does Cox truly allow the "market" and genuine free bargaining to reign. As was true in Pure, in Cox the independent directors are not afforded full defensive authority -- authority to pursue alternative transactions or restructurings. The "consent" that's sufficient to trigger deferential review under the Cox Reforms is highly constrained. It is not akin to true arms' length bargaining. The concept of true arms' length dealing contemplates that the parties have the option to deal with outsiders if the bilateral negotiations are unproductive. But this is not offered up in the proposed equitable reforms to freezeout doctrine. Accordingly, these reforms would leave minorities in an odd transactional limbo, with inadequate market protections and inadequate equitable ones. Hence, Cox's Dual Ratification proposal is an odd creature from the perspective of corporate governance, because it employs the special committee as if it is a true 
surrogate of the board, but does not afford the committee analogous power. Consent is an appealing idea for resolving the legal and financial conflicts presented by freezeouts, but the Cox Reforms do not adequately address the [814] defects to "totally voluntary" consents therein.

\section{Voluntary Consent and Legal Theory}

Contemporary academic theory adds strong impetus to the consent/bargaining model for fixing freezeout doctrine espoused in the Cox Reforms. [815] And Cox's Dual Ratification framework has been endorsed (as an adequate basis for deferential review) by several prominent scholars who have considered the issue. [816] Indeed, consistent with the discussion above, much of the allure of the Dual Ratification/free choice model for fixing freezeout doctrine relates to its "fit" with contemporary corporate legal theory. Four of these theoretic frameworks are described immediately below; they are: (i) neo-classical economic theory, (ii) agency theory, (iii) team production theory, and (iv) civil society theory. Each of these theoretic frameworks affords tremendous respect to the concept of free choice as a model for corporate governance and, ideally, corporate transactions. Each adds to the allure of the Dual Ratification framework.

Over the last twenty five years, neo-classical economic theory has influenced the development of corporate law in important respects. This school of thought has emphasized corporate law's role in supporting strong capital markets and economic growth. [817] A basic tenet of neoclassical economic theory is that people are rational, self-interested actors who will undertake a transaction only if they believe doing so is in their self-interest. [818] From the perspective of lawand-economics, the role of corporate law is to facilitate (presumably voluntary) transactions, since they are presumed to increase wealth overall. Along these lines, the consent to the freezeout by or on behalf of the minority shareholders, so long as it is freely given, suggests that the transaction is wealth-enhancing (and thus socially beneficial). If rational, fully informed, freely given consents could be given in freezeouts, then the proper role of the equity courts would be to "get out of the way." In essence, the Cox Reforms mostly dispose of the "if."

Corporate law has also been influenced by transaction cost economics, and in particular its concern for the effects of agency costs on the corporations' cost of capital. With Berle and Means' famous treatise in the distant background, [819] agency theory focuses on the "separation between ownership and control," and its implications for managers and investors. [820] As Professors Gilson and Gordon's scholarship has illuminated, once a controller is present agency costs run along two axes: controllers are better monitors of managerial misconduct, so there will be lower managerial agency costs for the equity holders. But the controller will engage in some degree of profiteering, which will increase the agency costs borne by the minority. [821] In this school of thought, the role of corporate law is to effect a system of organization which will decrease agency costs overall. Freezeouts present the potential for controllers to overreach to the detriment of minorities. But agency costs theorists might also object that freezeout litigation imports the potential for "litigation agency costs." Once again, if Cox's model of Dual Ratification could reliably yield a consensual freezeout transaction -- while minimizing litigation agency costs via deferential/business judgment review -- this would be a "win-win." If truly voluntary consent were a predicate of deferential review, the Cox Reforms would be an 
improvement in corporate law from the perspective of agency cost theory. But once again the voluntariness of the consents to the freezeout is at the crux of the matter.

Team production theory is especially helpful as a framework for conceptualizing the role of the board and, the role of special committees in freezeouts. [822] Team production theory focuses on the limits of contracting over the factors of production in the corporate enterprise. From the perspective of team production theory, the board's role is to support the fair and efficient distribution of the surplus value produced by the corporate enterprise. In effect, the mediating hierarch's role ensures that the parties' will have less incentive to shirk or engage in self-dealing (because they will have more assurance of obtaining a fair return from their contributions to the entity's success). Here again, if the special committee could freely exercise its discretion in responding to a freezeout, then the concern over rent-seeking by the controller would be obviated. [823] The norms of teamwork would not be undermined by the assignment of surplus in the freezeout. Once again, if the Cox Reforms could guarantee that the special committee would function effectively as an unconstrained, unbiased mediating hierarch, then from the perspective of team production theory, intensive judicial oversight would be unnecessary. The Cox Reforms would be an improvement over current freezeout doctrine.

Civil society theory also provides interesting insights into the problem of freezeouts (and other areas of corporate governance). From the perspective of civil society theory, corporations could be considered part of the broader network of private institutions and nongovernmental organizations that counterbalance government's more absolutist authority. Civil society, including potentially the structure of corporate governance, should be a "space" for positive, free interchange. [824] Civil society theorists encourage the features of institutions that make them consistent with norms of democratic organization and participation. [825] The Lynch Doctrine's fair dealing requirement provides an example of these values in corporate governance. Hence, if a freezeout occurred in the presence of genuinely fair dealings - including the informed, free consent of the independent directors and minority shareholders -- then it would be an exemplar of civil society virtues. Assuming the presence of such freely given consent, from the perspective of civil society theory, the Cox Reforms would be an improvement over current freezeout doctrine.[826]

These four theoretical perspectives on corporate governance help illuminate why the concept of freely given consent from directors and a majority of the minority shareholders is so appealing. The problem is, obviously, that nothing in the Cox Reforms improves the chances of the consents constituting Dual Ratification would in fact be voluntarily given. The "fit" between the above theories and the positive attributes of the recent reform proposals depends on this voluntariness. This is the most essential problem in freezeouts, but not one which the recent reform proposals redress.

\section{INHERENT COERCION: THE 800 POUND GORILLA THAT WON’T GO AWAY}

In Pure the court affirmed that inherent coercion operates in tender offer freezeouts as well as those based on cash-out mergers. To the contrary, in Cox the court assumes (with Vice 
Chancellor Strine again writing) that inherent coercion is no longer a serious concern.. First, it suggests that the passage of time has made the idea outmoded; that committees and minorities can now say "no" if they want to. [827] Second, Cox employs high pitched rhetoric to discredit, even ridicule, the concern over inherent coercion in freezeouts. Because inherent coercion cannot be "disproven," in Cox the court employs various rhetorical devices to mock and "shrink" its importance. This use of rhetoric to marginalize the inherent coercion concept is an important aspect of the Dual Ratification proposal, because they presume that the committee's and minorities' consents can be genuinely free given.

\section{A. Independent Directors' Capacity to Say "No" Now?}

At present, there are no empirical studies that support the conclusion that committees can reject unfair freezeout proposals. The few existing empirical analyses of freezeouts that exist address different issues; they do not provide evidence that would suggest the threat of inherent coercion has been minimized.[828] Indeed, whether committees can (or under what conditions they can) freely reject inadequate freezeout offers is a question that seems especially difficult to resolve empirically. [829] Such a study would first need to identify which deals offered too low a price. This question alone would involve a complex valuation exercise for each company in the data set sampled. Using premiums over market price would not be a reliable indicator of fair price, for the reasons discussed above. [830] It would be possible to gather data reflecting committee disapprovals, but impossible to ascertain the number of times that committees were pressured into acquiescing to too low a price because they feared worse for the minority if they resisted, or because they lacked adequate authority to pursue financial or transactional alternatives. Though individual case studies might be revealing, conducting this research with a data set large enough to support robust conclusions would be extraordinarily difficult. Hence, it is highly premature to conclude that we now know that committees can reject unfair proposals, so that inherent coercion and judicial scrutiny for fairness is outmoded. There may be valid policy reasons for wishing that committees had the resources to resist unfair freezeouts, but there are solid reasons for skepticism.

Leaving aside empirical measures, social science evidence on group dynamics does not present an encouraging picture of committees' capacity and propensity to reject unfair deals. [831] To the contrary, the emerging social science data reveals that the persistent socio-demographic homogeneity in boards (and committees as subsets thereof) tends to foster a "group cohesion" dynamic and hence various cognitive biases that would lead directors (even outside directors) in the direction of being relatively conformist and passive in responding to proposals from a controller. [832] Nor are changes to the director election process that might force greater diversity forthcoming. [833] Because at least with true majority controllers in all likelihood the controller's representatives would occupy at least a majority of the board seats, this means that their conformity and passivity would generally lead to the freezeout proposal being approved. The power of controllers to influence the information that outside directors obtain would further perpetuate the cognitive biases weighing in favor of their approving the offer. [834]

The limits that protect directors from liability for breach of care also reinforce committees' 
inclination not to "make waves.” [835] Saying "yes" would be the path of least resistance. Saying "no," on the other hand, requires a greater investment of time on the committee directors' part, and the time constraints that affect outside directors are notorious. [836] The unresolved problem of outside director compensation also aggravates this problem. If outside directors are paid "too little” they may lack a powerful incentive to devote substantial time to their committee work. However, if outside directors are richly rewarded in a controlled company, they may be unwilling to show "ingratitude" for this largesse by disapproving of a freezeout offer. [837]

The many corporate scandals that came to light after December 2001 also suggest the limited efficacy of boards in preventing self-dealing by powerful corporate insiders including controlling shareholders. [838] In almost all of these scandals, the companies had substantial numbers of outside directors on their boards; Enron was exemplary in this fashion. [839] In many of these cases the independent directors approved transactions despite clear signs of self-dealing. [840] These recent scandals and the financial losses they caused suggest that caution is warranted before reducing the fiduciary protections afforded public investors on the rationale that committees' oversight will be sufficient to protect them from controllers' over-reaching. The court of chancery's careful scrutiny of the shabby work of the special committee in the Emerging Communications tender offer freezeout provides a cautionary tale in this respect. [841]

Finally, it is worth remembering that Lynch was decided by the Delaware Supreme Court only in 1994. Independent directors had already been "invented" as a significant institution of corporate governance, but their ratification was not a sufficient guarantee of fairness. In this respect Lynch's resolution that a committee's consent is insufficient indicia of a freezeout's fairness to warrant application of the business judgment rule cannot be relegated to bygone times, as Cox suggests.

\section{B. Institutional Investors' Capacity to Say “No” Now?}

The same caveats about the lack of evidence supporting committees' ability to say "no" to unfair freezeout proposals applies to minority shareholders. We simply do not possess such empirical evidence at this time regarding the ability of minority shareholders to say "no" to controllers.

In Cox the court places significant emphasis on the increased institutionalization of the public equity markets as a source of empowerment for minorities in freezeouts. [842] But corporate legal scholars have consistently been disappointed by the level of coordinated action by institutional investors, especially in relation to company specific matters. The factors that produce this effect are well documented. [843] Even institutional investors face significant transaction costs in evaluating and opposing a freezeout offer. Coordinated action is costly and there are still a variety of legal regulations [844] and financial conflicts of interest [845] that discourage coordinated action among institutional investors. In addition, institutional investors have differing financial incentives and investment strategies, [846] and this *902 diversity undermines their incentives and propensity to act in concert. In addition, institutional investors (especially hedge funds) are increasingly positioning themselves to respond to short term market price changes, as intensified 
by the role of arbitrageurs in corporate transactions. [847] These factors fit uneasily with the likelihood that institutions will band together to hold out for their fair share of going concern value when a controller offers a premium over the market price. Indeed, the pervasively shortterm orientation of contemporary securities markets favors acquiescence to the controller's freezeout, [848] even if it offers minorities less than their fair share of the gains from the transaction. Since investing is subject to trends and social norms, a decision to oppose a freezeout at a premium might even appear "irrational” read in the context of other investors' responses. [849] In any event, the major losses suffered by such institutional investors in Enron and other post 2001 corporate scandals [850] and also the continued granting of mega-options to executives even at underperforming companies with significant institutional ownership [851] suggests limits to the wisdom of relying on institutional investors to protect minorities' interests in freezeouts.

\section{Cox's Use of Rhetoric to Discredit Inherent Coercion}

The Cox court uses highly charged rhetoric to undermine the legitimacy of the inherent coercion concept and hence the need for applying Entire Fairness in freezeouts. These uses of rhetoric are analyzed below because they are suggestive of the climate in which reforming freezeout doctrine is being considered. That is, it appears to be safe (even for the court of chancery) to mock not only the contribution of plaintiffs' lawyers to the system, but also the need for meaningful judicial review in freezeouts. Cox's intense rhetoric suggests that the appeal of contract-based norms over fiduciary norms is so powerful in corporate law that to disagree is foolish, if not ridiculous. Because appearing foolish is painful, Cox's rhetorical attack against inherent coercion may be quite effective in persuading future courts' or commentators' against defending the legitimacy of inherent coercion and Entire Fairness review in freezeouts.

\section{Parody -- Funny But Disturbing}

The court's negative view of the inherent coercion concept-its intuition that the concept is misplaced, mistaken and plain silly-is evident in the vehicle through which it is "explained" in the Cox opinion. For purposes of convenience, this will be called the "Primate Parable:" [852]

All in all, it is perhaps fairest and more sensible to read Lynch as being premised on a sincere concern that mergers with controlling stockholders involve an extraordinary potential for the exploitation by powerful insiders of their informational advantages and their voting clout. Facing the proverbial 800 pound gorilla who wants the rest of the bananas all for himself, chimpanzees like independent directors and disinterested stockholders could not be expected to make sure that the gorilla paid a fair price. Therefore the residual protection of an unavoidable review of the financial fairness whenever plaintiffs could raise a genuine dispute of fact about that issue was thought to be a necessary final protection. [853]

The Primate Parable is intended to capture the reader's attention through a radical departure 
from the usual rhetorical boundaries of corporate law cases. In the above cited passage, inherent coercion "reads" as a strange departure from the overall logic of corporate governance, which does not usually require reference to gorillas and chimpanzees to make sense of it. By presenting the "logic" of the inherent coercion concept (the underpinning of the Lynch Doctrine) through the Primate Parable, the court effectively marginalizes that concept. It makes the inherent coercion concept look bizarre-an odd digression within the otherwise rational jurisprudence of corporate governance.

Secondly, it is only a tiny move from bizarre to silly, and the references to gorillas, chimpanzees and bananas implicitly provide license to laugh at the concept of inherent coercion. Most of us know gorillas and chimpanzees only from zoos and/or television cartoons, and bananas are the notorious stock of slapstick comedy. So maybe the inherent coercion concept is just laughable?

The more closely one considers the Primate Parable the stranger and more off-putting the logic of inherent coercion becomes. Though the "800 pound gorilla" is a cliché, it is also a grotesque metaphor. We don't want to look too closely at an 800 pound gorilla, maybe we should stop thinking about this overblown inherent coercion concept too? Besides, gorillas do not pay for bananas-this inherent coercion stuff makes no sense! That is the reaction that the Primate Parable evokes, in a serious and yet simultaneously comic, and thus brilliant, powerful mode of argumentation.

The analogy between independent directors, minority stockholders and chimpanzees is also belittling. The natural response to reading it is to reject the comparison. Independent directors and minority stockholders are not analogous to chimpanzees! If the inherent coercion concept is based on this false analogy, then the inherent coercion concept is grounded on a major mistake.

It is worth noting that the Primate Parable is used as the vehicle to "explain" inherent coercion not only in Cox, but also in the court's opinion in Pure, [854] and in a law review article authored by Vice Chancellor Strine. [855] This suggests that it resonates deeply with the Vice Chancellor and is being used to convey something highly important about the place of the inherent coercion concept in corporate law.

Another reason that one should take the Primate Parable seriously is that discrediting the continued legitimacy of the inherent coercion concept is critical to the law reform espoused by the court in Cox, Pure and Cysive (i.e. eliminating Entire Fairness review of freezeouts in cases of Dual Ratification). Because inherent coercion is not susceptible to being "disproven" at an empirical level (as described above), the court endeavors to shrink its significance through humorous disparagement. Poking fun at the inherent coercion concept does not diminish the importance of what is at stake, Cox contends that the Lynch Doctrine and its concern about inherent coercion is damaging both the litigation system and impairing economic efficiency. [856]

The Primate Parable has one other dimension worth noting. At bottom, the question the court is grappling with is when the rule of law and resort to the courts are fruitful. In essence, the 
Primate Parable mocks reliance on complex legal doctrines and resort to the courts to resolve disputes in freezeouts. This logic also operates through the contrast between primates and more highly reasoning homo sapiens. If we are so much more intelligent, then why can't we resolve our differences on our own, without resort to courts and overly complicated legal doctrines?

The Cox opinion uses a second stunning metaphor to discredit the Lynch Doctrine. This one, too, suggests that the concern for inherent coercion is "over the top;" that Entire Fairness review is distorting or perverting the system of litigation and corporate governance. [857] This metaphor appears in the court's description of the triangular settlement process involving committees, controllers and plaintiffs' lawyers in lawsuits filed under the Lynch Doctrine:

As the objectors point out and this court has often noted in settlement hearings regarding these kinds of cases in the past, the ritualistic nature of a process almost invariably resulting in the simultaneous bliss of three partiesthe plaintiffs' lawyers, the special committee, and the controlling stockholders-is a jurisprudential triumph of an odd form of tantra. [858]

Like the reference to gorillas and chimpanzees, the opinion's references to "ritual," "bliss," and "tantra" are so unusual in the lexicon of corporate law as to be arresting. Describing settlement negotiations under the Lynch Doctrine through an analogy to over-the-top emotions (bliss) and exotic spiritual or sexual practices (tantra) makes the Lynch Doctrine appear excessive and even bizarre in its effects. Read in the context of a formal legal opinion, these references are unsettling. The court is inviting us to be uncomfortable with the Lynch Doctrine and its effects. In its references to "bliss" and "tantra" the court is suggesting that the Lynch Doctrine has caused corporate law that governs freezeouts to spin out of control and become decadent and disorderly. [859] In this fashion Cox implicitly admonishes that law reform is overdue.

These are the opinions most potent use of rhetoric, but the rest should be noted as well because they operate cumulatively (albeit implicitly) in service of the court's law reform agenda.

\section{Inherent Coercion -- A "Sociological Inference"}

A further example of the court's use of rhetoric to discredit the Lynch Doctrine is its reference to inherent coercion as a "sociological inference." [860] By tying implicit coercion to sociology, rather than economics or positive law, Cox once again marginalizes it within the lexicon of corporate law. Economics has been respected as a legitimate science and source of inspiration for corporate law. In contrast, until quite recently, sociology and the other social sciences were not acknowledged as legitimate sources of authority for courts to rely upon in deciding corporate cases. [861]

Equally powerful is the court's statement that the inherent coercion core concept underlying 
the Lynch Doctrine is based merely on an "inference."

\section{A Pointed Rhetorical Question}

In Cox, the court employs a pointed rhetorical question to undermine judicial concern for inherent coercion. Rhetorical questions are not actual questions of course, but rather masked declarations of certainty. [862] In just this discussion-ending mode, the opinion states:

If both the independent directors and the disinterested stockholders are given the ability to say no and do not, ought we not presumptively assume that the transaction was fair? [863]

This rhetorical question appears near the conclusion of the opinion, after the court's many objections to the Lynch Doctrine have been presented. It is intended to evoke a positive response. "Yes! Dual Ratification should end the inquiry into fairness in a freezeout!"

Furthermore, this rhetorical question contains a tautology. It assumes away the problem of inherent coercion by positing that the committee and the minority shareholders were given a genuine opportunity to reject the freezeout proposal. This doubt about the total voluntariness of minorities' and committees' consents in freezeouts is what motivates the invocation of the Entire Fairness standard under the Lynch Doctrine in the first place.

\section{Corporate Law -- A Species of Commercial Law?}

As part of its argument against continued adherence to the Entire Fairness standard for freezeouts, the Cox opinion makes a claim about corporate law's essential nature and proper boundaries. The statement is extremely terse, but quite powerful in its effect for this reason. The claim is as follows: "This is corporate law, after all, a species of commercial law ..." [864]

The statement quoted above achieves its rhetorical power through two definitions: one is "species" and the other "commercial law." Taking the latter first, commercial law is sometimes used broadly as a synonym for private law but it has a narrower usage. For example, the Uniform Commercial Code governs numerous areas of commercial law including for example sales, leases, negotiable instruments, bank deposits, fund transfers, letters of credit, bulk sales, and warehouse receipts. [865] It is unquestionably important to businesses and consumers to have a clear and coherent system of commercial laws. But the above list illustrates that the commercial law is more microeconomic in comparison to the kind of macroeconomic effect that Cox elsewhere claims are relevant to corporate law in general and the Lynch Doctrine in particular. For example, earlier in Cox the court expressly claims that the Lynch Doctrine is inhibiting profitable transactions that produce efficiency for the economy overall and liquidity for minorities in particular. [866] And in Pure the court muses about whether endorsing Lynch or Solomon would be more consistent with corporate law's objective of supporting strong capital markets. [867] By limiting the proper concerns of corporate law to commercial law, then, the court is implicitly narrowing its appropriate focus. 
This narrowing of the proper concerns of corporate law is accentuated by the claim that corporate law is merely a "species" of commercial law. Within biological classification, a species is the lowest level of taxonomic classification. By using the term species, the court is fitting corporate law under the genus of commercial law, in effect further shrinking the appropriate domain and concerns of corporate law. By invoking the taxonomy of biological science, Cox makes the claim that corporate law is a sub-category of commercial law and advances the court's rhetorical arguments that freezeout doctrine should move away from a focus on "Entire Fairness," and let the parties negotiate on their own.

\section{Creating Urgency through Hyperbole}

The Cox opinion is rife with hyperbole that creates an air of urgency around its law reform proposals. For example, strict adherence to the Entire Fairness standard for freezeouts has generated "perverse incentives" [868] for both defense and plaintiffs' counsel. It has "cast doubt on the integrity of the representative litigation process." [869] The Lynch Doctrine has made it "impossible" [870] for controllers "ever" [871] to avoid a review of a cash-out merger's financial fairness because "any" amended complaints that the plaintiffs file could not be dismissed. [872] According to the opinion, it is an "undeniable reality that any merger with a controlling shareholder is subject to review for fairness." [873] The Cox opinion contends that minorities' claims of unfairness in freezeouts "cannot ever be dismissed" irrespective of their merit. [874] These are only a few examples of the court's use of hyperbole to convey the urgency of limiting Entire Fairness review in freezeouts. [875]

\section{Proposals: TWEnTy-First Century StANDARdS For FreEzeOUTS}

\section{A. A UNIFIEd DOCTRINE FOR FrEEZEOUTS}

The Delaware Court of Chancery's recent opinions in Pure, Cysive, and Cox make an important contribution to illuminating the negative effects of having two "tracks" in freezeout doctrine. As Pure and Cox contend, the structural differences between tender offer freezeouts and cash-out mergers do not reflect substantially different capacities for overreaching by controllers. [876] Minorities and committees have no less reason to fear ex-post retribution from controllers if they oppose a tender offer freezeout instead of a cash-out merger. And controllers' informational and timing advantages persist in freezeouts based on tender offers, as in cash-out mergers. The greater force of the prisoner's dilemma in freezeouts based on tender offers mandates applying equivalently rigorous fiduciary safeguards to these transactions.

Just as importantly, the operation of different standards of fair price in the two freezeout formats, in conjunction with the "hit or miss" nature of the appraisal remedy has undermined the securities markets' capacity accurately to price controllers' capacity for overreaching in freezeouts. The application of a fair price duty in cash-out mergers and no fair price duty in tender offer freezeouts sends mixed signals to the capital markets about the value of the 
minorities' shares. If the markets do not fully reflect the substantial risks of opportunism presented by tender offer freezeouts, then minorities are probably overpaying for their shares. In the alternative, if the securities markets are accurately discounting the minorities' shares to take account of controllers' potential for opportunism in tender offer freezeouts, then this hole in the web of fiduciary prohibition against self dealing may be driving up the cost of raising public equity capital. In either case, the Delaware Court of Chancery's critique that excess complexity in freezeout doctrine is inefficient is well founded in this context. It should be redressed through law reform that would unify the fiduciary standards applicable to freezeouts.

Furthermore, as the analysis of Solomon and Glassman herein revealed, it isn't clear that the supreme court ever intended for there to be two tracks in freezeout doctrine. The Delaware Supreme Court has never had the opportunity to review a genuine tender offer freezeout. The Solomon decision exhibits striking shortcomings as landmark precedent. These shortcomings are evidence that the Delaware Supreme Court never intended to validate a separate, looser framework of fiduciary duties for freezeouts based on tender offers.

\section{B. ENTIRE FAIRNESS AS THE STANDARD FOR FREEZEOUTS}

The Entire Fairness standard represents the most appropriate basis for a unified doctrine for freezeouts. The Lynch doctrine's fair price promise has facilitated minority shareholders' capacity to command higher premiums in freezeout negotiations than they can in negotiations where no fair price duty has applied. In the absence of a fair price duty, controllers can take a variety of actions that will force the trading price of the minorities' shares downward, and then profit from such actions by compelling a freezeout. The more the market fears controllers' capacity for coercion and overreaching, the deeper the discount will become; the less the controller will have to pay in the freezeout-unless a fair price duty applies. By extending Lynch's fair price duty to tender offer freezeouts, corporate law can limit this kind of downward cycle and its negative effects for minorities and corporations' cost of capital. In this respect, the application of Entire Fairness review to controllers' cash-out mergers has provided a safeguard against freezeouts in which controllers' gains come at the minorities' expense. This same protection should apply in tender offer freezeouts.

The Lynch doctrine's concern about minorities' capacity for free choice in freezeouts reflects that shareholders have a property interest in their shares which cannot be "seized" by controllers without some meaningful due process, and the payment of full value to the minority. Second, the fair dealing aspect of the Entire Fairness standard limits controllers' capacity to subordinate the distinct institution that is the corporate board to their private interests. The Cox opinion itself emphasizes that "empowerment of centralized management, in the form of boards of directors" [877] is an axiomatic principle in corporate law, and one relevant to freezeouts. Application of the Entire Fairness standard is further warranted on account of the fact that target directors have not been recognized to possess inherent fiduciary authority to explore transactional alternatives to a freezeout over the opposition of a controller. This is an especially odd result given target directors' broad discretion to defend against a hostile tender offer proposal from a third party. 
Target directors' defensive authority in freezeouts should be expanded so it is on a par with their authority in third-party offers, but in the end this is a matter separate and distinct from the standard of review applicable to controllers in freezeouts.

The Cox Reforms would allow Dual Ratification to trigger deferential review in a freezeout, and the court claims in Cox, that in doing so it would not diminish the integrity-enforcing role of corporate law. However, the court is able to arrive at this conclusion only by assuming away the essential concern underlying the Lynch Doctrine, i.e. the concern for inherent coercion. The appeal of the "prochoice" solution for fixing freezeouts is powerful. But the court in Cox cannot "disprove" the continued validity of inherent coercion and disparages it through a variety of rhetorical devices. In an ideal world, people would freely bargain to mutually beneficial outcomes and courts would not be involved. But minorities' and committees' consents to freezeouts are not likely to be genuinely freely given and should not be treated as the product of arms' length dealings. The absence of strong fiduciary protections would further erode minorities' and committees' capacity to resist unfair freezeout proposals.

\section{THE LYNCH DOCTRINE IS NOT “BROKEN”}

The Cox and Cysive opinions present a series of claims intended to prove that adherence to the Entire Fairness standard for freezeouts has serious deleterious effects on the legal system and economy. This Article has demonstrated that these claims are exaggerated. The Lynch Doctrine is not a free pass for plaintiffs' lawyers to proceed to discovery on mere allegations of unfairness especially mere allegations of unfair price. The courts have the ability to dismiss claims that appear nonmeritorious and to keep fees to plaintiffs' lawyers in settlements in check. They can do so, moreover, without endorsing the business judgment rule as the presumptive standard for freezeouts.

Cox's objective of limiting shareholder suits in freezeouts is problematic. First, minorities' ability to bring class action claims against freezeouts under Lynch's Entire Fairness standard is essential to protecting their welfare. Second, limiting equitable claims in freezeouts would not necessarily result in net reduction in litigation against freezeouts, because there would likely be an offsetting increase in appraisal and federal securities law actions. Finally, if claims in freezeouts are routinely dismissed on the pleadings, then the Delaware courts will no longer be developing the transactional choreography that has had a salutary effect on deal making and corporate investment. The Cox court did not take this hidden cost into account in its proposal.

\section{Auctions And Market Checks}

The Cox opinion contends that the business judgment rule should be the presumptive standard of review for freezeouts unless either the target directors or minority shareholders have disapproved of the offer (or, so long as they both approve of the offer). There are many problems with this proposal, as reviewed above. In addition, the argument in favor of the business judgment rule in freezeouts ignores the fact that judicial deference is the exception and not the rule in high stakes M\&A transactions. For example, even the "ordinary" duty of care is applied 
by courts with heightened scrupulousness in reviewing, sales to third parties. [878] Under Revlon the courts apply heightened scrutiny to sales of corporate control. [879] And under Blasius the courts apply heightened scrutiny to actions interfering with shareholders' voting rights, as may often occur in takeover battles. [880] Furthermore, freezeouts involving de facto controllers actually involve sales of control as interpreted under Revlon's progeny. [881] On this basis, the target's directors under present law have a duty to pursue an auction or market check to obtain the best price reasonably available for the minorities' shares in responding to a de facto controller's freezeouts. The new listing standards will require a majority of independent directors on boards where there is only a de facto controller. [882]

Instead of imposing a fiduciary requirement of a market check or auction in all freezeouts however, the courts should work from the standard-of-review orientation reflected in the Lynch Doctrine. In pursuing a freezeout, controllers should either truly empower the committee to negotiate at arms' length or their transaction should be subject to scrutiny for fairness in the event of a shareholder challenge. Where there is evidence that the controller's freezeout was accepted by an independent committee after it had been empowered to pursue an auction or market check, and was approved by a majority of the minority shares, then the transaction should be eligible for deferential review. However, to ensure that the market check or auction reveals evidence of the company's going concern value, the controller would have to agree to be a seller if a bid emerged that was higher than one it was willing to match. These circumstances would constitute compelling evidence of arms length dealings and warrant judicial deference in a challenged freezeouts. This strategy would give controllers the opportunity to structure their freezeouts in a way that would provide for dismissals on the pleadings. If the controller is not willing to match a third party's bid at a higher value, then there is no reason to presume that it is offering going concern value for the minorities' shares, and no reason for the court to allow the freezeout judicial deference.

\section{E. Burdens of Proof And Burden Shifting Going Forward}

The Lynch Doctrine's insistence that controllers bear the initial burden of proof in freezeouts is consistent with the basic judicial presumption in self-dealing transactions. Hence, courts should continue to impose the burden of proof on controllers in freezeouts in both formats. However, the Lynch Doctrine's burden-shifting device has helped to provide an incentive for controllers to promote fair dealing in freezeouts and to invite the scrutiny of minorities and independent directors in their freezeouts. Although this Article rejects Cox's proposal that Dual Ratification should trigger deferential review, the Cox opinion does make a powerful case for the "complementarity" of Dual Ratification in freezeouts. [883] Hence Dual Ratification should be required in order for defendants to shift the burden of proof to the plaintiffs. If there was Dual Ratification but not as auction or market check, the plaintiff would have to demonstrate the fundamental unfairness of the freezeout in order to obtain a recovery.

\section{CONCLUSION}

Corporate academics often analogize corporate law to contract law; many envision the 
corporation as a "nexus of contracts." The Cox Reforms would take this analogy a step further by leaving controllers and minorities to the terms of their bargains in freezeouts. The bargaining model is appealing, as is reducing unnecessary litigation. However, there are powerful reasons to doubt that committees and minorities are capable of negotiating freely with controllers. On this basis, this Article concludes that courts should apply the Entire Fairness standard to both cashout mergers and tender offer freezeouts, except where a controller has allowed a market check or auction conducted by independent directors to proceed prior to the approval of the freezeout. Instead of endorsing deferential review for freezeouts, consistent with the Cox Reforms, courts in equity should continue to have a meaningful role in developing standards of conduct and standards of review for freezeouts, unless market forces have genuinely been allowed to operate for the benefit of minority shareholders. The costs of equity becoming more tolerant of controllers' overreaching in freezeouts are potentially very large, surely larger than recent freezeout cases from the Delaware court of chancery reflect.

[a1]. New York Law School, Professor of Law (1999-present); Associate Professor (1994-1999); Director, NYLS Center on Business Law \& Policy; AALS Section on Business Associations, Executive Committee Member (2004present); Sloan Visiting Professor, Georgetown University Law Center (2003-2004); Visiting Associate Professor, Cornell Law School (Spring 2000); Fried, Frank, Harris, Shriver \& Jacobson LLP (1989-1993).

[1]. Freezeouts are a subset of the broader going private phenomenon which is sweeping the corporate landscape. See, e.g., Kit R. Roane, The New Face of Capitalism, U.S. NEWS \& WORLD REP., Dec. 4, 2006, at 48 ("Private buyers are gobbling up some of the premier names in Corporate America."); Andrew Ross Sorkin, HCA Buyout Highlights Era of Going Private, N.Y. TIMES, July 25, 2006, at A1. The academic commentary on going private transactions is burgeoning. See, e.g., Ronald J. Gilson and Charles K. Whitehead, Deconstructing Equity: Public Ownership, Agency Costs and Complete Capital Markets, (forthcoming Columbia Law Review), available at http://ssrn.com/abstract=991352. Claims have been made that costs associated with the enactment of the Sarbanes Oxley Act of 2002, Pub. L. No. 107-204, 116 Stat. 745 (codified as amended at 15 U.S.C. §§ 7201-66 (Supp. IV 2004) and in scattered sections of 11 U.S.C., 28 U.S.C. and 29 U.S.C.) have influenced firms to delist. For an analysis of the influence of Sarbanes-Oxley in this regard, see, e.g., Ehud Kamar, Pinar Karaca-Mandic, \& Eric L. Talley, Going-Private Decisions and the Sarbanes Oxley Act of 2002: A Cross-Country Analysis, USC CLEO Research Paper No. C06-5, USC Law Legal Studies Paper No. 06-10 (August 2006). However, broader macroeconomic forces, and especially the availability of low cost debt capital and sophisticated securities markets are more significant factors influencing this phenomenon.

[2]. Delaware corporate fiduciary doctrine currently includes two different definitions of controlling shareholders and affords them equivalent treatment in freezeouts. Most obviously, a controlling shareholder is one who owns the shares required to control the outcome of shareholder votes, including votes on director elections and fundamental transactions including mergers (referred to herein as "true majority holders"). Secondly, the doctrine allows that shareholders who own less than such absolute voting power may be considered controlling shareholders as a result of their possession and exercise of direct and indirect managerial authority (referred to herein, "de facto controllers.”) See, e.g., In reCysive, Inc. S'holders Litig., 836 A.2d 531, 551-53 (Del. Ch. 2003) (“... the analysis of whether a controlling stockholder exists must take into account whether the stockholder, as a practical matter, possesses a combination of stock voting power and managerial authority that enables him to control the corporation, if he so wishes.”). For the argument that the distinction between true majority controllers and de facto controllers should be more salient in corporate legal doctrine, see Mary Siegel, The Erosion of the Law of Controlling Shareholders, 24 DEL. J. CORP. L. 27 (1999).

[3]. To clarify further, as used herein, the term "freezeout" refers to a transaction in which a controlling shareholder 
effectuates the buyout of the remaining publicly traded common stock of a company through (i) a combination of a tender offer and short-form merger (the short-form merger governed by DEL. CODE tit. 8, § 253 (2007)), or (ii) a long-form, one-step, negotiated, cash-out merger (governed by DEL. CODE tit. 8, § 251 (2007), amended by 76 Del. Laws. ch. 145 (2007)). (Citations to the Delaware Code are to the official online version at http://www.delcode.delaware.gov/ (last accessed on August 1, 2007). For purpose of linguistic convenience, the impersonal pronoun "it" is used herein to refer to a controlling stockholder-irrespective of whether it is a person or a corporate entity; and "controller" is used as an abbreviated form of "controlling shareholder."

[4]. Most commentators believe that the risks of minorities receiving too low a price in a freezeout is substantial. For a study contending otherwise, see Thomas W. Bates, Michael L. Lemmon and James S. Linck, Shareholder Wealth Effects and Bid Negotiation in Freeze-Out Deals: Are Minority Shareholders Left Out in the Cold? 81 J. FIN. ECON. 681 (2006).

[5]. See infra notes 32-34. For two deferential treatments of freezeouts that also favor deferential review, i.e. applying the business judgment rule upon minority shareholder and independent director consent to the transaction, see Guhan Subramanian, Fixing Freezeouts, 115 YALE L. J. 2, 48-64 (2005) [hereinafter "Fixing Freezeouts"]; Ronald J. Gilson \& Jeffrey N. Gordon, Controlling Controlling Shareholders, 152 U. PA. L. REV. 785, 838 (2003) [hereinafter "Gilson \& Gordon”].

[6]. For discussion of the "Entire Fairness" standard for freezeouts, see infra notes 94-104 and accompanying text.

[7]. In Delaware, most corporate claims are heard as "equitable" claims brought before the court of chancery. As used herein "equity" or "equitable review" refers to the adjudication of corporate claims by the court of chancery consistent with principles of fiduciary duty. For further discussion of the chancery court's equity jurisdiction and the nature of equitable standards, see William T. Quillen and Michael Hanrahan, A Short History of the Delaware Court of Chancery, 1792-1992, 18 DEL. J. CORP. L. 819 (1993).

[8]. This Article exclusively discusses cash-out mergers by controlling shareholders. For this reason, the terms “controllers' cash-out mergers" and "cash-out merger freezeouts” are avoided for purposes of brevity.

[9]. Alternative mechanisms for freezeouts include reverse stock splits and asset sales, but these are far more uncommon. For further discussion of the mechanical aspects of going private, see e.g., Michael J. McGuinness \& Timo Rehbock, Going-Private Transactions: A Practitioner's Guide, 30 DEL. J. CORP. L. 437 (2005).

[10]. See, e.g., In rePure Res., Inc., S'holders Litig., 808 A.2d 421, 446 (Del. Ch. 2002) (“... the better rule is that there is no duty on [the controller's] part to permit the target board to block the bid through use of the pill. Nor is there any duty on the part of the independent directors to seek blocking power.").

[11]. See infra notes 84-88 and accompanying text.

[12]. See, e.g., Citron v. E. I. Du Pont de Nemours \& Co. 584 A.2d 490, 500-02 (Del. Ch. 1990). For further discussion of the concept of inherent coercion, see infra text accompanying notes 121-27.

[13]. The prohibition on secret and otherwise unfair profit-taking by corporate insiders is validated as the core concept of corporate fiduciary loyalty doctrine. See, e.g., Austin W. Scott, The Fiduciary Principle, 37 CAL. L. REV. 539 (1949); Deborah A. DeMott, Beyond Metaphor: An Analysis of Fiduciary Obligation, 1988 DUKE L. J. 879 (1988). For discussion of the laxness in courts' enforcement of the prohibition on self-dealing outside of transactions involving controllers, see Victor Brudney, Contract Versus Fiduciary Duty in Corporate Law, 38 B.C. L. REV. 595 (1997).

[14]. See, e.g., Thorpe by Castleman v. CERBCO, Inc., 676 A.2d 436 (Del. 1996) (affirming controllers' right to 
vote against sale of substantially all assets consistent with their private interests); Bershad v. Curtiss-Wright Corp., 535 A.2d 840, 845 (Del. 1987) ("clearly a stockholder is under no duty to sell its holdings in a corporation, even if it is a majority shareholder, merely because the sale would profit the minority.”); Sinclair Oil Corp. v. Levien, 280 A.2d 717, 722 (Del. 1971) (allowing controller to shape dividend policy and corporate development plans of subsidiary in ways beneficial to it, irrespective of the minority's preference); Shlensky v. Wrigley, 237 N.E. 2 d 776 (Ill. Ct. App. 1968) (applying business judgment rule broadly to accommodate controllers' view of company's best interest).

[15]. This limit on controllers' discretion rests on the axiom that the corporate board, and not any shareholder constituency, has authority over corporate-level transactions. As stated in the landmark case of Aronson v. Lewis, "A cardinal precept of the General Corporate Law of the State of Delaware is that directors, rather than shareholders, manage the business and affairs of the corporation. DEL. CODE ANN tit. 8, § 141(a)." Aronson v. Lewis, 473 A.2d 805, 811 (Del. 1984).

[16]. SeeKahn v. Lynch Commc'n Sys., Inc., 638 A.2d 1110 (Del. 1994); Weinberger v. UOP, Inc., 457 A.2d 701 (Del. 1983). For further discussion see infra Part I. With respect to the fiduciary standards applied to self-dealing transactions involving controllers outside of freezeouts, see, e.g., Kahn v. Tremont Corp., 694 A.2d 422, 428 (Del. 1997); Emerald Partners v. Berlin, 787 A.2d 85, 93 n.52 (Del. 2001). The limitation on self-dealing by controllers is similar to but more idiosyncratic than that applied to directors and officers. On the latter, see e.g., Weinberger, 457 A.2d at 710 ("When directors of a Delaware corporation are on both sides of a transaction, they are required to demonstrate their utmost good faith and the most scrupulous inherent fairness of the bargain. The requirement of fairness is unflinching in its demand that where one stands on both sides of a transaction, he has the burden of establishing its entire fairness sufficient to pass the test of careful scrutiny by the courts.” (citations omitted)). For the lesser fiduciary standards applied to controllers' tender offers, see Solomon v. Pathe Commc'ns Corp., 672 A.2d 35 (Del. 1996), as discussed in depth infra Part

[17]. Much scholarly debate is inspired by the open-ended texture of corporate fiduciary standards. See, e.g., William T. Allen, Jack B. Jacobs \& Leo E. Strine, Jr., Function Over Form: A Reassessment of Standards of Review in Delaware Corporation Law, 56 BUS. LAW. 1287 (2001) (suggesting ways that corporate fiduciary doctrine should be streamlined and simplified); Ehud Kamar, A Regulatory Competition Theory of Indeterminacy in Corporate Law, 98 COLUM. L. REV. 1908 (1998) (describing the "network effects" that foster indeterminacy in corporate fiduciary law); Melvin Aron Eisenberg, The Divergence of Standards of Conduct and Standards of Review in Corporate Law, 62 FORDHAM L. REV. 437 (1993) (suggesting ways that the duality between standards of conduct and standards of review in corporate fiduciary law may be fruitful); Reza Dibadj, Delayering Corporate Law, 34 HOFSTRA L. REV. 469 (2006) (arguing that the duality between standards of conduct and standards of review produces unproductive complexity).

[18]. See Gilson \& Gordon, supra note 5, at 834 (“... the result is likely to be dueling experts, each applying the tools of modern finance to end up at vastly different valuations.”).

[19]. The court in Pure expressly notes this tension and responsibility. Pure, 808 A.2d at 434 (“... judges must supplement the broadly enabling features of statutory corporation law with equitable principles sufficient to protect against abuse and unfairness, but not so rigid as to stifle useful transactions ...”). There is no more contentious subject in contemporary, "private" law than the definition of fairness and the role of the courts in promoting it. For a law-and-economics inspired critique of the problem, see LOUIS KAPLOW \& STEVEN SHAVELL, FAIRNESS VERSUS WELFARE (2002); compare e.g., Martha C. Nussbaum, Flawed Foundations: The Philosophical Critique of a (Particular Type of) Economics, 64 U. CHI. L. REV. 1197 (1997) (arguing that the law and economics movement has failed adequately to account for the importance of nonpecuniary values in its consideration of "fairness"); Faith Stevelman Kahn, Bombing Markets, Subverting the Rule of Law: Enron, Financial Fraud and September 11, 2001, 76 TULANE L. REV. 1579 (2002) (arguing that capital market regulation fails to take account of democratic notions of fairness at the peril of strong markets and a strong economy). The growing behavioral law and economics literature attempts a richer account of motivation that includes concerns over fairness. See, e.g., 
Christine Jolls, Cass R. Sunstein \& Richard Thaler, A Behavioral Approach to Law and Economics, 50 STAN. L. REV. 1471 (1998).

[20]. Corporate legal scholars increasingly affirm the benefits of regulating controlling shareholders' actions through the application of more flexible judge-made standards as opposed to more rigid statutory ones; as well as the importance of legal limits on controllers' self-dealing as a foundation of strong capital markets. See Mark J. Roe, Legal Origins, Politics, and Modern Stock Markets, 120 HARV. L. REV. 460, 470 (2006) ("The first link between legal origins and financial markets is said to be how the legal system protects small investors. '[C]ommon law countries protect shareholders better than do civil law countries and especially better than French civil law countries.' If small investors fear that insiders could rob them, they will not invest in the insiders' firms. If outsiders do not buy, then a deep stock market does not develop, and the big owners-founding families and their successorsare locked in. Common law systems protect minority stockholders well via judge-made fiduciary duties, while civil law systems, the theory goes, are too rigid to protect minority stockholders.” (citations omitted)). For further refinements to this idea, see also Ronald J. Gilson, Controlling Shareholders and Corporate Governance: Complicating the Comparative Taxonomy (August 2005) (ECGI-Law Working Paper No. 49/2005), available at http// ssrn.com/abstract=784744 and Ronald J. Gilson, Background Paper: Corporate Governance, The Equity Contract and the Cost of Capital: Incremental and Accretive Reform Strategies (International Corporate Governance Meeting-Hanoi Vietnam, December 6, 2004), available at http:// www.oecd.org/dataoecd/19/58/34081304.pdf.

[21]. The SEC initiated a program of rule-making that would have regulated the substantive fairness of freezeout transactions, but backed away from so doing in the end. For this history and discussion of the role of federal law (mostly in regulating disclosure) in freezeouts see infra. Part I, C

[22]. The website for Delaware's Division of Corporations states that: "[m]ore than half a million business entities have their legal home in Delaware including more than $50 \%$ of all U.S. publicly-traded companies and $60 \%$ of the Fortune 500.” Del. Dep't of State, Div. of Corps., Why Choose Delaware as Your Corporate Home?, available at http://www.corp.delaware.gov/default.shtml.

[23]. For evidence and analysis of Delaware law's predominant influence on freezeouts, see, e.g., Guhan Subramanian, Post-Siliconix Freeze-Outs: Theory \& Evidence (May 2005) (Harv. John M. Olin Discussion Paper Series No. 472), available at http://www.law.harvard.edu/programs/olin_ center/papers/pdf/Subramanian_472_revised.pdf. For a broader discussion of Delaware's dominant influence on corporate law, see, e.g., Oren Bar-Gill, Michal Barzuza \& Lucian Bebchuk, The Market for Corporate Law, 162 J. INST. \& THEOR. ECON. 134 (2006). Delaware's influence on corporate law is sometimes described as a "race to the bottom," and sometimes as a "race to the top." For the landmark treatment of the former claim, see William Cary's Yale Law Journal article discussed infra note 112 and accompanying text. The locus classicus of the race to the top literature is Ralph K. Winter, Jr., State Law, Shareholder Protection and the Theory of the Corporation, 6 J. LEGAL STUD. 251 (1977). For discussion of the policies that have shaped the evolution of Delaware corporate legal doctrine, see Lawrence A. Hamermesh, The Policy Foundations of Delaware Corporate Law, 106 COLUM. L. REV. 1749 (2006). Federal law's complex influence on this "race" is presently receiving deserved attention. See, e.g., Mark J. Roe, Delaware's Competition, 117 HARV. L. REV. 588 (2003); William W. Bratton \& Joseph A. McCahery, The Equilibrium Content of Corporate Federalism, 41 WAKE FOREST L. REV. 619 (2006).

[24]. Weinberger v. UOP, Inc., 457 A.2d 701 (Del. 1983).

[25]. Kahn v. Lynch Commc'n Sys., Inc., 638 A.2d 1110 (Del. 1994).

[26]. Solomon v. Pathe Commc'ns Corp., 672 A.2d 35 (Del. 1996).

[27]. Glassman v. Unocal Exploration Corp., 777 A.2d 242 (Del. 2001).

[28]. See infra Part II. 
[29]. The first explicit treatment of the issue by the Delaware Court of Chancery appears in In re Siliconix, Inc. S'holders Litig., C.A. No. 18700, 2001 WL 716787 (Del. Ch. June 19, 2001).

[30]. This insight has tremendous relevance to the going private phenomenon because the private equity funds that are purchasing formerly public companies will wish to profit from issuing minority equity stakes. Before purchasing such minority interests, however, outside investors should demand assurance regarding courts' willingness to scrutinize controllers' conduct in freezeouts and other self-dealing transactions.

[31]. Notably, the Pure, Cysive and Cox opinions, infra notes 32-34 were each authored by Vice-Chancellor Leo E. Strine, Jr., who is noted for his bold efforts to reshape Delaware corporate legal doctrine. Biographical data for Vice-Chancellor Strine is available at http:// sec.gov/spotlight/proxyprocess/bio052507/lestrine.pdf. Although this Article is critical of the positions the Vice-Chancellor takes in Pure, Cysive and Cox, the attention it devotes to them reflects their likely seminal importance. In addition to deciding many high profile cases in his nearly ten years as a vice chancellor, and authoring numerable law review articles, Vice Chancellor Strine is teaching at Harvard Law School and has taught at University of Pennsylvania School of Law. In reviewing his remarkable achievements, the Financial Times referred to Vice-Chancellor Strine as the "Wunderkind of US Corporate Law." John Gapper, Capitalist Punishment, FIN. TIMES, Jan. 29, 2005, available at http://search.ft.com/ftArticle? queryText=capitalist + punishment $\& y=9 \&$ aje $=$ true $\& x=12 \& i d=050129000270$.

[32]. Pure, 808 A.2d 421.

[33]. In re Cysive, Inc. S'holders Litig., 836 A.2d 531 (Del. Ch. 2003).

[34]. In reCox Commc'ns, Inc. S'holders Litig., 879 A.2d 604 (Del. Ch. 2005).

[35]. The business judgment rule is a protean concept in corporate law. As a presumption in favor of the challenged transaction in shareholder litigation, the business judgment rule mirrors the statutory principle that the business affairs of corporations should be run by or under the direction of the board. DEL. CODE tit. 8, § 141(a) (2007). So long as the plaintiffs have not demonstrated a material conflict of interest, a noncorporate motivation for the decision or egregious failure of attentiveness on the part of the decision-maker, the business judgment rule will insulate a challenged transaction from any searching (indeed virtually any meaningful) substantive judicial review. See, e.g., Cede \& Co. v. Technicolor, Inc., 634 A.2d 345, 360 (Del. 1993) (the business judgment rule "operates as both a procedural guide for litigants and a substantive rule of law") [hereinafter "Cede II"]. For academic discussion, see, e.g., Stephen M. Bainbridge, The Business Judgment Rule as Abstention Doctrine, 57 VAND. L. REV. 83 (2004). The recent litigation involving the Disney's board's approval of Michael Ovitz's termination package provides a fascinating, high stakes account of the application of the business judgment rule. See In reWalt Disney Co. Derivative Litig., 907 A.2d 693 (Del. Ch. 2005), aff'd, 906 A.2d 27 (Del. 2006).

[36]. See Cox, 879 A.2d at 606.

[37]. Id. at 646-47.

[38]. Id. at 643 (“... Lynch has generated perverse incentives for both defense and plaintiffs' counsel that cast doubt on the integrity of the representative litigation process.”).

[39]. Within the academic discussion of corporate law, the superiority of "private ordering" to formal law is an important subject of debate. See, e.g., Gillian Hadfield \& Eric Talley, On Public versus Private Provision of Corporate Law, 22 J. L. ECON. \& ORG. 414 (2006). The promulgation of new director independence criteria by the stock exchanges and NASD are examples of this favored, "privatized" mode of governance. See, e.g., NYSE LISTED COMPANY MANUAL §§ 303A.01-02 (2007). 
[40]. As described and discussed in the text, promoting controllers' ability to obtain dismissals on the pleadings is an explicit objective of the Cox Reforms. See, e.g., Cox, 879 A.2d at 646 (arguing in favor of judicial deference in the review of claims in freezeouts because "... this incentive would enable transactional planners to know that they can structure transactions in a way that affords them the opportunity to obtain a dismissal on the complaint”); $\underline{i d}$. at 646 ("It was thought preferable in Pure Resources to keep the strands separate until there is an alteration in Lynch, lest the less than confidence inspiring pattern of "Lynch litigation" replicate itself across-the-board in all going private transactions, thereby deterring the procession of offers that provide valuable liquidity to minority stockholders and efficiency for the economy in general.”). See also Leo E. Strine, Jr., The Delaware Way: How We Do Corporate Law and Some of the New Challenges We (and Europe) Face, 30 DEL. J. CORP. L. 673, 678 (2005) ("Delaware tries to respect the business judgment of disinterested directors and stockholders. How? By invoking the protection of the business judgment rule if an interested transaction is approved by a majority of the independent directors or by a majority of the disinterested stockholders, after full disclosure. The idea, of course, is that the investment of ultimate power over the transaction in impartial directors or stockholders suffices to police the conflict. By this instrumental means, Delaware law can protect the resulting business decision without any loss of integrity, because the decision was made or ratified by persons whose interests were aligned with those of the corporation and its stockholders.”).

[41]. On his blog, http://busmovie.typepad.com/ideoblog, Professor Larry E. Ribstein refers to the Cox opinion as a "classic-to-be” ... "so interesting for so many reasons."

[42]. Cox, 879 A.2d at 646 ("In this way, the alteration [of the standard of review for freezeouts] brings this area of our law into harmony with the rest of Delaware corporate law that gives substantial deference to decisions made by disinterested, independent directors and approved by disinterested, non-coerced stockholders. That deference is consistent with the central notion of our law, which respects business judgments made by impartial directors and approved by unconflicted stockholders."). This line of reasoning fails adequately to grapple with the problem of coerced consents, and especially the difference between a director's ratification of a controller's transaction and an independent board's proposal of a transaction in the best interest of all shareholders.

[43]. See, e.g., Pure, 808 A.2d 443 (endorsing expanding Solomon's anti-coercion prohibitions to freezeouts because it "provides a relatively non-litigious way to effect going private transactions ..."); Cysive, 836 A.2d at 549 ("These realities suggest that the Lynch doctrine, if it is to be perpetuated, could be usefully simplified.”); Cox, 879 A.2d at $\underline{606}$ (“... it is most probable that the defendants settled simply because they had, under Lynch, no other economically efficient option for disposal of the lawsuit.”).

[44]. Cox, 879 A.2d at 644 ("This alteration would promote the universal use of a transactional structure that is very favorable to minority stockholders ..."); id. ("Importantly, this revised standard would not diminish the integrity enforcing potential of litigation in any material way, in my view”).

[45]. Id. at 624 (doctrine that encourages freezeouts is favorable because it creates "more rationally organized corporations"); id. at 646 ("Lynch litigation" and review for Entire Fairness should be limited because they inhibit freezeouts that create "efficiency for the economy in general").

\section{*** footnotes 46 to 68 have been moved; they appear as notes __ to _}

[69]. Solomon, 672 A.2d 35, 39-40. See infra Part__ for an in-depth analysis of Solomon.

[70]. Lynch, 638 A2d at 1116 ("Entire fairness remains the proper focus of judicial analysis in examining an interested merger, irrespective of whether the burden of proof remains upon or is shifted away from the controlling or dominating shareholder, because the unchanging nature of the "interested" transaction requires careful scrutiny.”). 
[71]. The usual rule, once self-dealing or other conflict of interest has been demonstrated by the plaintiff, is that the defendant has the burden of proof. See, e.g., Emerald Partners v. Berlin, 726 A.2d 1215, 1222 (Del. 1999) (“Once the entire fairness standard has been implicated, as here, the defendants, at least initially, bear the burden of demonstrating the two basic aspects of fair dealing and fair price." (citation omitted)); Mills Acquisition Co. v. Macmillan, Inc., 559 A.2d 1261, 1280 (Del. 1989) ("When faced with such divided loyalties, directors have the burden of establishing the entire fairness of the transaction to survive careful scrutiny by the courts."); Keenan v. Eshleman, 2 A.2d 904, 909 (Del. 1938) ("In the second place, dealing as they did with another corporation of which they were sole directors and officers, they assumed the burden of showing the entire fairness of the transaction.”).

[72]. Lynch, 638 A.2d at 1116;Rosenblatt v. Getty Oil Co., 493 A.2d 929 (Del. 1985) (holding that the informed vote by a majority of minority shares shifts the burden of proving the unfairness of the conflicted merger entirely to the plaintiffs).

[73]. It is crucial that the directors conduct an auction of the entire company; otherwise they test only the value of the minority equity stake, rather than the company's "full value” or "going concern value." Importantly, this Article does not propose any new substantive regulations or limitations on freezeouts. The reforms it endorses, as described in Part V infra, speak only to the standard of review that should apply-and hence the factors and incentives that will affect the parties' choices in weighing either making or accepting a freezeout offer. If the controller has impeded an independent board's evaluation and pursuit of alternatives to the controller's offer, then the residual ambiguity surrounding the allocation of gains in the freezeout warrants imposing the burden of proving fairness on the controller. In the alternative, the Cox opinion presumes that with Dual Ratification there is only a minimal chance of unfairness, so that litigation is wasteful and unwarranted. See Cox, 879 A.2d at 647 ("If both the independent directors and the disinterested stockholders are given the ability to say no and do not, ought we not presumptively assume the transaction was fair?”). The parallel Cox draws between genuine arms'-length dealing and Dual Ratification in freezeouts does not comport with Weinberger's tenets, however. Weinberger, 457 A.2d at 709 n.7 (action taken "as if" at arms'-length will serve merely as "strong” but not dispositive evidence of fairness in a cashout merger).

[74]. Proving entire fairness in such a circumstance is certainly possible. For cases in which the sale process was held defective but the transaction was deemed fair in its entirety, see Kahn v. Lynch Communc'n Systems, Inc., 669 A.2d 79, 87 (Del. 1995); Cinerama, Inc. v. Technicolor, Inc., 663 A.2d 1156, 1180 (Del. 1995).

[75]. At least they should not do so without scrutinizing the target board's rationale for accepting the freezeout over competing alternatives, as the best alternative for the minority. For recent law review articles contending that corporate law should protect minority shareholders in freezeouts, as part of its role in reducing the agency costs of capital, see Brett A. Margolin \& Samuel J. Kursh, The Economics of Delaware Fair Value, 30 DEL. J. CORP. L. 413, 414 (2004) (describing the importance of an expansive interpretation of "fair value" in appraisal actions); Lawrence A. Hamermesh \& Michael L. Wachter, The Fair Value of Cornfields in Delaware Appraisal Law, 31 J. CORP. L. 119, 146-74 (2005) (noting the importance of the corporate opportunity doctrine as incorporated into the fiduciary doctrine applicable to freezeouts); Gilson \& Gordon, supra note 5, at 837 (“... the concern is to ensure that the minority receives a premium that reflects a fair share of the synergy gains").

[76]. Weinberger, supra note 24.

[77]. Lynch, supra note 25.

[78]. Solomon, supra note 26.

[79]. Glassman, supra note 27. 
[80]. As the risks of holding a minority equity stake increase, the cost of issuing minority equity stakes will increase for companies, unless the market is unaware of the true risks. See infra text accompanying notes 169-72.

\section{[81]. Pure, supra note 32.}

[82]. Cox, supra note 34.

[83]. Cysive, supra note 33.

[84]. DEL. CODE tit. 8, § 251 (2007), amended by 76 Del. Laws ch. 145 § § 4-7 (2007).

[85]. DEL. CODE tit. 8, § 216(3) (2007) ("Directors shall be elected by a plurality of the votes of the shares in person or represented by proxy at the meeting and entitled to vote on the election of directors....”). In any matter submitted to the shareholders for voting, because not all shares are voted, the outcome may often be determined by a shareholder owning less than a genuine majority of the outstanding voting stock-i.e. by a de facto controller.

[86]. DEL. CODE tit. 8, § 216(2) (2007) ("In all matters other than the election of directors, the affirmative vote of the majority of the shares present in person or represented by proxy at the meeting and entitled to vote on the subject matter shall be the act of the shareholders."); DEL. CODE ANN. tit. 8, § 109(a) (2007) (“... the power to adopt, amend or repeal by-laws shall be in the stockholders entitled to vote....").

[87]. DEL. CODE tit. 8, § 271(a) (2007) (“Any corporation may ...sell, lease or exchange all or substantially all of its property or assets... as its board of directors or governing body deems expedient and for the best interests of the corporation, when and as authorized by the holders of a majority of the outstanding stock of the corporation entitled to vote thereon ...”).

\section{[88]. DEL. CODE tit. 8, § 242(b)(1) (2007).}

[89]. See, e.g., McMullin v. Beran, 765 A.2d 910, 919 (Del. 2000) ("The ... Board owed fiduciary duties of care, loyalty and good faith to all ... shareholders."); Weinberger, 457 A.2d at 710 ("There is no dilution of this obligation where one holds dual or multiple directorships, as in a parent-subsidiary context."); Iman Anabtawi, Some Skepticism About Increasing Shareholder Power, 53 U.C.L.A. L. REV. 561 (2006) (suggesting that intrashareholder conflicts represent a further rationale for vesting primary decision-making authority in the board).

[90]. Consistent with the status quo bias and the overconfidence principle, most directors will rationalize that they are doing the right thing for the company by avoiding conflict with a controller, and maximizing their chance of remaining on the board. For scholarship applying the insights of behavioral psychology to corporate law, see, e.g., Donald C. Langevoort, Behavioral Theories of Judgment and Decision Making in Legal Scholarship: A Literature Review, 51 VAND. L. REV. 1499 (1998) (applying behavioral psychology to different legal fields); Marleen A. O'Connor, The Enron Board: The Perils of Groupthink, 71 U. CIN. L. REV. 1233 (2003) (documenting the psychological pressures to squelch healthy dissent in groups); Lynne L. Dallas, A Preliminary Inquiry into the Responsibility of Corporations and Their Officers and Directors for Corporate Climate: The Psychology of Enron's Demise, 35 RUTGERS L.J. 1 (2003) (applying principles of behavioral psychology and human moral development to explain Enron's demise); A. Mechele Dickerson, A Behavioral Approach to Analyzing Corporate Failures, 38 WAKE FOREST L. REV. 1 (2003) (discussing the overconfidence bias). For a pathbreaking work on group psychology, law and the dynamics of the boardroom, see James D. Cox \& Harry L. Munsinger, Bias in the Boardroom: Psychological Foundations and Legal Implications of Corporate Cohesion, 48 LAW \& CONTEMP. PROBS. 83, 99-108 (Summer 1985).

[91]. As late as 1976 and 1977, in Delaware and elsewhere, mergers intended to eliminate minorities were presumptively wrongful. See, e.g., Kellogg v. Georgia Pac. Paper Corp., 227 F. Supp. 719 (W.D. Ark. 1964); 
Marshel v. AFW Fabric Corp., 533 F.2d 1277 (2d Cir. 1976); Green v. Santa Fe Indus., Inc., 533 F.2d 1283 (2d Cir. 1976), rev'd, on other grounds, 430 U.S. 462 (1977); Elliott J. Weiss, Balancing Interests in Cash-Out Mergers: The Promise of Weinberger v. UOP, Inc., 8 DEL. J. CORP. L. 1 (1983) (discussing progress from early legal prohibition on cash-out mergers to their gradual legitimization in the last several decades of the 20th century).

[92]. Singer v. Magnavox Co., 380 A.2d 969 (Del. 1977); Tanzer v. Int'l Gen. Indus., Inc., 379 A.2d 1121 (Del. 1977); Roland Int'l Corp. v. Najjar, 407 A.2d 1032 (Del. 1979).

[93]. Weinberger, 457 A.2d at 715 ("In view of the fairness test which has long been applicable to parent-subsidiary mergers, the expanded appraisal remedy now available to shareholders, and the broad discretion of the Chancellor to fashion such relief as the facts of a given case may dictate, we do not believe that any additional meaningful protection is afforded minority shareholders by the business purpose requirement ... Accordingly, such requirement shall no longer be of any force or effect.” (citation omitted)).

[94]. The landmark definitions of "fair dealings" and "fair price," established in Weinberger, are as follows:

The concept of fairness has two basic aspects: fair dealing and fair price. The former embraces questions of when the transaction was timed, how it was initiated, structured, negotiated, disclosed to the directors, and how the approvals of the directors and stockholders were obtained. The latter aspect of fairness relates to the economic and financial considerations of the proposed merger, including all relevant factors: assets, market value, earnings, future prospects, and any other elements that affect the intrinsic or inherent value of a company's stock.... However, the test for fairness is not a bifurcated one as between fair dealings and price. All aspects of the issue must be examined as a whole since the question is one of entire fairness.

Weinberger, 457 A.2d at 711 (citations omitted). As the second appeal in Kahn v. Lynch clarified, courts have interpreted "Entire Fairness" to require that a transaction be "fair in its entirety" rather than "entirely fair in every respect.” SeeKahn v. Lynch Commc'n Sys., 669 A.2d 79, 90 (Del. 1995) (despite problems pertaining to the Special Committee's approval process, the disputed cash-out merger was judged beneficial to the shareholders, hence fair). See alsoCinerama, Inc. v. Technicolor, Inc., 663 A.2d 1156, 1180 (Del. 1995) [hereinafter "Cede III"] (despite problems with the sale process, including the absence of a market check and a rushed review by the board, the company's sale through the merger was fair).

[95]. Weinberger, 457 A.2d at 713 ("Fair price obviously requires consideration of all relevant factors involving the value of a company.... elements of future value, including the nature of the enterprise, which are known or susceptible of proof as of the date of the merger and are not the product of speculation, may be considered."). The issue of which elements of future value should be excluded in equity and in an appraisal, are significant open questions. For commentary, see Hamermesh \& Wachter, supra note 75.

[96]. Weinberger, 457 A.2d at 711-12. See, e.g., Cinerama, Inc. v. Technicolor, Inc., 663 A.2d 1134, 1153 (Del. Ch. 1994), aff'd, 663 A.2d 1156 (Del. 1995) ("Thus in assessing overall (or entire) fairness in this instance the court must consider the process itself that the board followed, the quality of the result it achieved and the quality of the disclosures made to the shareholders to allow them to exercise such choice as the circumstances could provide.”).

[97]. Weinberger, 457 A2d. at 711-12. In actuality, the Entire Fairness standard was first endorsed for parent/subsidiary mergers by the Delaware Supreme Court in Sterling v. Mayflower, a case in which the parent acquired its subsidiary in a merger using its stock as consideration. SeeSterling v. Mayflower Hotel Corp., 93 A.2d 107, 109-10 (Del. 1952).

[98]. See, e.g., Weinberger, 457 A.2d at 710-12;id. at 710 ("Given the absence of any attempt to structure this transaction on an arm's length basis, Signal cannot escape the effects of the conflicts it faced, particularly when its designees on UOP's board did not totally abstain from participation in the matter. There is no 'safe harbor' for such divided loyalties in Delaware.”); $\underline{i d}$. at 709 n.7 (“... the result here could have been entirely different if UOP had appointed an independent negotiating committee of its outside directors to deal with Signal at arm's length.”). 
[99]. Id. at 711 ("Part of fair dealing is the obvious duty of candor required by Lynch I ..."); id. at 710 ("Completeness, not adequacy, is both the norm and the mandate under present circumstances." (citing Lynch v. Vickers Energy Corp., 383 A.2d 278, 281 (Del. 1977)). Weinberger is crucially important in the evolution of the case law identified under the rubric of the "fiduciary duty of disclosure." For commentary, see Lawrence A. Hamermesh, Calling Off the Lynch Mob: The Corporate Director's Fiduciary Disclosure Duty, 49 VAND. L. REV. 1087 (1996) (arguing that future courts should exercise caution in expanding the significance of "fiduciary disclosure duties"); Kahn, Transparency and Accountability, supra note 66 (arguing that corporate loyalty doctrine would be incoherent if it tolerated dissembling in communications between directors and shareholders).

[100]. For a discussion of the twin life of standards of conduct (affecting behavior ex ante), and standards of review (affecting remedies ex post), see Eisenberg, Divergence, supra note 17.

[101]. See Weinberger, 457 A.2d at 709 n.7.

[102]. See id. For data attesting to the employment of special committees in freezeouts-even in tender offer freezeouts in many instances, see Subramanian, Theory \& Evidence, supra note 23.

[103]. In Weinberger, the court scrutinized the work done by the investment banker representing UOP (the target subsidiary), and was highly critical of its work. Weinberger, 457 A.2d at 712 ("There was no disclosure of the circumstances surrounding the rather cursory preparation of the Lehman Brothers' fairness opinion. Instead, the impression was given UOP's minority that a careful study had been made, when in fact speed was the hallmark, and Mr. Glanville, Lehman's partner in charge of the matter, and also a UOP director, having spent the weekend in Vermont, brought a draft of the 'fairness opinion letter' to the UOP directors' meeting on March 6, 1978 with the price left blank.”).

[104]. See, e.g., Rosenblatt v. Getty Oil Co., 493 A.2d 929, 938-39 (Del. 1985); Cinerama, 663 A.2d at 1174, 117677.

[105]. See supra notes 91-92 and accompanying text. The following discussion benefited from the historical information provided in ARTHUR M. BORDEN \& JOEL A. YUNIS, GOING PRIVATE (1982).

[106]. Weiss, supra note 91.

[107]. A. A. Sommer, Going Private: A Lesson in Corporate Responsibility, [1974-1975 Transfer Binder] Fed. Sec. L. Rep. (CCH) I 84,692, at 82,695 (Nov. 14, 1974) ("I speak today of a newer and currently, at least, more disquieting fad. That is the fad of 'going private.”').

[108]. Notice of Public Fact-Finding Investigation and Rulemaking Proceedings in the Matter of "Going Private" Transactions by Public Companies and Their Affiliates, SEC Rel. No. 33-5567, 40 Fed. Reg. 7947, 7949 (Feb. 24, 1975).

[109]. Id. at 7950. The "business purpose" requirement briefly endorsed by the Delaware courts was probably a direct outgrowth of this SEC proposal. For a discussion of the business purpose requirement, see citations in note 92, supra.

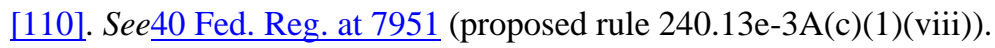

[111]. BORDEN \& YUNIS, supra note 105, at § 2.07.

[112]. William L. Cary, Federalism and Corporate Law: Reflections on Delaware, 83 YALE L.J. 663 (1974). 
[113]. See, e.g., Gilson \& Gordon, supra note 5; Subramanian, Fixing Freezeouts, supra note 5; Peter V. Letsou \& Steven M. Haas, The Dilemma That Should Never Have Been: Minority Freeze Outs in Delaware, 61 BUS. LAW. $\underline{25(2005)}$.

[114]. Consistent with Mark Roe's insights, freezeouts provide a fascinating context in which to analyze the interaction of federal and state legal regimes in corporate law. Roe, Delaware's Competition, supra note 23.

[115]. As a further counterpoint to the present acceptance of going private deals, see Bevis Long-streth, SEC Commissioner, Speech to the International Bar Association, Management Buyouts: Are Public Shareholders Getting a Fair Deal?, [1983-1984 Transfer Binder] Fed. Sec. L. Rep. (CCH) ๆ 83,436 (Oct. 6, 1983).

[116]. Going Private Transactions by Public Companies or Their Affiliates, SEC Rel. No. 33-6100, 44 Fed. Reg. 46736 (Aug. 8, 1979).

[117]. Santa Fe Indus., Inc. v. Green, 430 U.S. 462 (1977).

[118]. See supra note 92.

[119]. Compare In re Trans World Airlines, Inc. S'holders Litig., Civ. A. No. 9844, 1988 WL 111271, at *7 (Del. Ch. Oct. 21, 1988) (advocating the business judgment rule should apply to cash-out mergers if approval was obtained from a board with a majority of independent directors, a special committee, or a majority of the minority shares) with Citron, 584 A.2d at 499-502 (endorsing Entire Fairness as the universal standard of review for controllers' going private mergers on account of their implicit power to coerce such consents).

[120]. Weinberger, 457 A.2d at 703 ("However, where corporate action has been approved by an informed vote of a majority of the minority shareholders, we conclude that the burden entirely shifts to the plaintiff to show that the

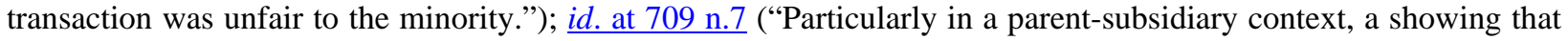
the action taken was as though each of the contending parties had in fact exerted its bargaining power against the other at arms' length is strong evidence that the transaction meets the test of fairness." (emphasis added; citations omitted.)).

[121]. Lynch, 638 A.2d at 1116.

[122]. For an in-depth discussion of inherent coercion and the Lynch Doctrine's concern about fair dealings and free consent in freezeouts, see infra Part IV, F. The concept of implicit coercion was first described at length in Citron, 584 A.2d 499-502. The relevant part of Citron is cited in Lynch, 638 A.2d at 1116-17 (citations omitted):

Parent subsidiary mergers ... are proposed by a party that controls and will continue to control, the corporation, whether or not the minority stockholders vote to approve or reject the transaction. The controlling stockholder relationship has the potential to influence, however subtly, the vote of [ratifying] minority stockholders in a manner that is not likely to occur in a transaction with a non-controlling party. Even where no coercion is intended, shareholders voting on a parent subsidiary merger might perceive that their disapproval could risk retaliation of some kind by the controlling stockholder. For example, the controlling stockholder might decide to stop dividend payments or to effect a subsequent cash out merger at a less favorable price, for which the remedy would be time consuming and costly litigation. At the very least, the potential for that perception, and its possible impact on a shareholder vote, could never be fully eliminated. Consequently, in a merger between the corporation and its controlling stockholder-even one negotiated by disinterested, independent directors-no court could be certain whether the transaction terms fully approximate what truly independent parties would have achieved in an arm's length negotiation. Given that uncertainty, a court might well conclude that even minority shareholders who have ratified a ... merger need procedural protections beyond those afforded by full disclosure of all material facts. One way to provide such protections would be to adhere to the more stringent entire fairness standard of judicial review. 
[123]. Weinberger, 457 A.2d at 703.

[124]. Rosenblatt v. Getty Oil Co., 493 A.2d 929, 937 (Del. 1985) (holding that "approval of a merger ... by an informed vote of a majority of the minority shareholders, while not a legal prerequisite, shifts the burden of proving the unfairness of the merger entirely to the plaintiffs").

[125]. See, e.g., In re Trans World Airlines, Inc. S'holders Litig., Civ. A. No. 9844, 1988 WL 111271 (Del. Ch. Oct. 21, 1988).

[126]. Delaware decisions addressing self-dealing transactions, which do not involve controllers, sometimes allow disinterested, informed ratification by directors or shareholders to cure a fiduciary breach or at least trigger deferential review. The Delaware Supreme Court has not entirely resolved the issue. Compare, e.g., Orman v. Cullman, Civ. A. 18039, 2004 WL 2348395 (Del. Ch. Oct. 20, 2004) (finding that the informed, uncoerced vote of company's disinterested public stockholders "extinguished" the plaintiffs' remaining breach of fiduciary duty claims in the context of a sale of the company); Cooke v. Oolie, Civ. A. 11134, 1997 WL 367034, at *9 (Del. Ch. June 23, 1997) (suggesting that Delaware Supreme Court has weighed in favor of giving limited effect even to proper ratification, so that the business judgment rule is not "reinstated" due to ratification); Marciano v. Nakash, 535 A.2d 400 (Del. 1987) (stating in dicta that proper ratification would effectuate business judgment deference so that plaintiff could recover only upon proof of 'waste').

[127]. Citron v. E.I. Du Pont de Nemours \& Co., 584 A.2d 490 (Del. 1990).

[128]. Lynch, 638 A.2d at 1117 (“... an approval of the transaction by an independent committee of directors or an informed majority of minority shareholders shifts the burden of proof on the issue of fairness from the controlling or dominating shareholder to the challenging shareholder-plaintiff.”). See Weinberger, 457 A.2d at 703 (“... but in all this, the burden clearly remains on those relying on the [burden-shifting] vote [i.e. the defendants] to show that they completely disclosed all material facts relevant to the transaction.”).

[129]. The wariness the courts show towards allowing ratification of potential fiduciary loyalty breaches reflects the important stature of the duty of loyalty within corporate law. For a classic statement of the importance of the duty of loyalty, see, e.g., Bayer v. Beran, 49 N.Y.S.2d 2 (N.Y. Sup. Ct. 1944) ("The concept of loyalty, of constant, unqualified fidelity, has a definite and precise meaning. The fiduciary must subordinate his individual and private interests to his duty to the corporation whenever the two conflict.” (citation omitted)).

[130]. For example, no prior tender offers by controllers are cited by the Delaware Supreme Court in its landmark opinion in Lynch v. Vickers Energy Corp., 383 A.2d 278, 281 (Del. 1977) (ruling that "complete candor" was required in the controller's disclosures in its tender offer). Moreover, short form mergers in tender offer freezeouts (i.e. combined tender offer/short-form mergers) are nowhere evident in the myriad short form mergers reviewed by the Delaware Supreme Court in Glassman v. Unocal Exploration Corp., 777 A.2d 242 (Del. 2001).

[131]. Solomon, 672 A.2d 35 (Del. 1996). For commentary on the absence of authoritative precedent on tender offer freezeouts, see Letsou \& Haas, supra note 113, at 45 (“... only one reported decision between 1996 and 2001 attempted to invoke Solomon in connection with a freezeout transaction structured as a tender offer followed by a long or short-form merger, In re Life Technologies, Inc. Shareholders Litigation [Civ. A. 16513, 1998 WL 1812280 (Del. Ch. Nov. 24, 1998)].”).

[132]. Glassman, 777 A.2d 242 (Del. 2001). Solomon and Glassman are discussed at length in Part III, infra.

[133]. See, e.g., Kahn v. Tremont Corp., 694 A.2d 422, 428 (Del 1997). 
[134]. Solomon, 672 A.2d at 40.

[135]. In re Siliconix Inc. S'holders Litig., Civ. A. 18700, 2001 WL 716787 (Del. Ch. June 21, 2001).

[136]. In rePure Res., Inc. S'holders Litig., 808 A.2d 421 (Del. Ch. 2002).

[137]. In reCox Commc'ns, Inc. S'holders Litig., 879 A.2d 604 (Del. 2005).

[138]. For detailed discussion of the early short-form merger statutes and case law, see Weiss, supra note 91. The evolution of the case law is also explored in Glassman, 777 A.2d at 244-48 (attesting to the enactment of the shortform merger statute in Delaware by 1937, with its modern version appearing by 1957).

[139]. The Williams Act, Pub. L. No. 90-439, 82 Stat. 454 (1968) (codified as amended in 15 U.S.C. §§ 78m(d)-(e), 78n(d)-(f) (2000 \& Supp. IV 2004)) [hereinafter "Williams Act"] governs tender offers for securities registered under the Exchange Act of 1934, ch. 404, Title 1, § 12, 48 Stat. 881, 892 (codified as amended at 15 U.S.C. § 781 (2000 \& Supp. IV 2004)) [hereinafter “Exchange Act”]. See also infra notes 141-49.

[140]. For a survey of federal tender offer law and regulation, see THOMAS LEE HAZEN, THE LAW OF SECURITIES REGULATION ch. 11 (5th ed. 2005); id. at § 11.1 ("The securities laws contained a regulatory gap. By and large, there were no disclosure provisions applicable to tender offers.”).

[141]. Section 14(d) of the Exchange Act (codified at 15 U.S.C. § 78n(d) (2000)) requires that any person planning a tender offer subject to the Exchange Act's registration and reporting requirements must file all solicitations, advertisements, and any other materials used in connection with the offer with the SEC prior to the distribution of the tender offer material. The tender offeror must file a long form Schedule TO, 17 C.F.R. § 240.14d-100 (2007).

[142]. See Section 14(e) of the Exchange Act (codified at 15 U.S.C. § 78n(e) (2000)) and 17 C.F.R. § 240.14e-1 (2007).

[143]. See 15 U.S.C. § 78m(e) (2000 \& Supp. IV 2004). The disclosure called for by SEC Rule 13e-3, 17 C.F.R. § 240.13e-3 (2007), applies to going private deals irrespective of whether they are structured as cash-out mergers (where proxies or information statements are required to be filed) or tender offer freezeouts (where tender offer filings must be made, consistent with 17 C.F.R. § 240.14d-3 (2007)). Under Rule 13e-3, the bidder must file, update, and finalize a Schedule 13E-3 with the SEC. In both instances the Rule 13e-3 disclosures are adjunctive to the proxy or tender offer statement disclosures.

[144]. See Section 14(d)(4) of the Exchange Act (codified at 15 U.S.C. § 78n(d)(4) (2000)); Schedule 14D-9, 17 C.F.R. § 240.14d-101 (2007). Schedule 14D-9 is the disclosure document that must be filed in connection with any recommendation for or against tender offers. 17 C.F.R. § 240.14d-9 (2007).

[145]. See 15 U.S.C. § 78n(d)(6) (2000); 17 C.F.R. § 240.14d-8 (2007).

[146]. 17 C.F.R. § 240.14e-1(a) (2007).

[147]. 15 U.S.C. § 78n(d)(5) (2000); 17 C.F.R. § 240.14d-7 (2007).

[148]. 15 U.S.C. \& 78n(d)(7) (2000).

[149]. For analysis and citation to the legislative history of the Williams Act, see Piper v. Chris-Craft Indus., Inc., 430 U.S. 1, 30-31, reh'g denied, 430 U.S. 976 (1977) ("The sponsors of this legislation were plainly sensitive to the 
suggestion that the measure would favor one side or the other in control contests; however, they made it clear that the legislation was designed solely to get needed information to the investor, the constant focal point of the committee hearings. Senator Williams articulated this singleness of purpose, even while advocating neutrality: 'We have taken extreme care to avoid tipping the scales either in favor of management or in favor of the person making the takeover bids. S. 510 is designed solely to require full and fair disclosure for the benefit of investors.' 113 Cong. Rec. 24664 (1967).”).

[150]. See id.

[151]. DEL. CODE tit. 8, § 253(a) (2007).

[152]. This matter was resolved in the Delaware Supreme Court's holding in Glassman, 777 A.2d 242, described infra Part III.A.2.

[153]. Glassman, 777 A.2d 242.

[154]. See Subramanian, Theory and Evidence, supra note 23, at 1 (indicating that as of 2005, at least 2/3 of freezeouts proceeded through cash-out mergers).

[155]. See, e.g., Smith v. Van Gorkom, 488 A.2d 858, 874 (Del. 1985) (in evaluating a proposed merger the directors must inform themselves of all information reasonably available to them).

[156]. Unitrin, Inc. v. American Gen. Corp., 651 A.2d 1361, 1387 (Del. 1995) (defenses that are neither preclusive nor coercive fall within the permissible range of defenses available to target directors); Unocal Corp. v. Mesa Petroleum Co., 493 A.2d 946, 955 (Del. 1985) (directors can respond to threat to corporation by adopting reasonable takeover defenses).

[157]. For example, in the landmark case of Piper v. Chris-Craft Industries, Inc., 430 U.S. 1 (1977), the Supreme Court refused to afford a private remedy to the tender offeror who lost to the winning bidder.

[158]. See Unocal, 493 A.2d at 954 ("Finally, the board's power to act derives from its fundamental duty and obligation to protect the corporate enterprise, which includes stockholders, from harm reasonably perceived, irrespective of its source.”); Moran v. Household Int'l, Inc., 500 A.2d 1346, 1355 (Del. 1985) (approving target board's use of poison pill to defend against coercive or inadequate tender offers).

[159]. Solomon, 672 A.2d at 39-40;see alsoEisenberg v. Chicago Milwaukee Corp. 537 A.2d 1051, 1056 (Del. Ch. 1987) (enumerating conduct that would be deemed coercive in controllers' tender offers for preferred shares).

[160]. In re Pure, 808 A.2d at 437 ("Tender offers are not addressed by the Delaware General Corporation Law ("DGCL"), a factor that has been of great importance in shaping the line of decisions addressing tender offers by controlling stockholders...."); $i d$. at 437-38 ("Because no consent or involvement of the target board is statutorily mandated for tender offers, our courts have recognized that "[i]n the case of totally voluntary tender offers ... courts do not impose a right of the shareholders to receive a particular price.”). From a statutory perspective, an activist role for the target board can be grounded in the board's plenary authority under Section 141 of the DGCL. SeeDEL. CODE tit. 8, § 141 (2007), amended by 76 Del. Laws ch. 145, § 1 (2007). Moreover, in tender offers from third parties, the Delaware courts have established a rich and nuanced set of equitable principles that affirm target directors' duties to defend the company and the shareholders from inadequate or coercive bids. No such equivalent equitable authority is recognized in the case law in relation to controllers' bids, although they create an even greater risk of coercion and unfairness than tender offers from third parties do. The paradox is explored in Pure, 808 A.2d at 429-31. Furthermore, consistent with the landmark Schnell decision, courts have extended fiduciary principles based on the exigencies of the context in the interest of protecting the parties and reducing the agency costs of capital. 
They have very rarely been constrained by the statutory architecture. See id. at 434 (citing Schnell v. Chris-Craft Indus., Inc., 285 A.2d 437, 440 (Del 1971) (“[I]nequitable action does not become permissible simply because it is legally possible.”)).

[161]. SeeDEL. CODE tit. 8, § 251(b) (2007).

[162]. See Pure, 808 A.2d at 441.

[163]. For further discussion of controllers' ability to act coercively in a tender offer freezeout, see Part III.B., infra.

[i]. See, e.g., Roane, supra note 1, at 48 ("Time was, America's largest corporations would fight tooth and nail (and with poison pills) to remain public companies. No longer.”); A Growing Aversion to Ticker Symbols, in DEALBOOK (Andrew Ross Sorkin, ed., N.Y. TIMES Jan. 29, 2007), available at http://dealbook.blogs.nytimes.com/2007/01/29/a-growing-aversion-to-ticker-symbols/ (“'Everyone, it seems, is hopping on the buyout bandwagon these days. Even the big public companies once thought untouchable are now wistfully talking about the success of firms like the Blackstone Group.”); Serena Ng, Gregory Zuckerman \& Michael Hudson, Ready to Deal: \$60 Billion in Two Days; A Spate of Mergers, Buyouts Announced Across the Globe; Borrowing Stretches Targets, WALL ST. J, NOV. 21, 2006, at C1.

[ii]. See, e.g., Class Action Fairness Act of 2005, Pub L. No. 109-2, 119 Stat. 4 (codified as amended in scattered sections of 28 U.S.C.); Alison Frankel, It's Over-Tort Reformers, Business Interests, and Plaintiffs Lawyers Themselves Have Helped Kill the Mass Tort Bonanza and It's Not Coming Back, AM. LAWYER, Dec. 2006, at 78; Michael Orey, How Business Trounced the Trial Lawyers, BUS. WK., Jan. 8, 2007, at 44. The proper scope of private litigation and its effect on the economy are huge issues in contemporary American law and public policy. See, e.g., Manhattan Institute for Policy Research, Trial Lawyers, Inc.; A Report on the Lawsuit Industry in America, 2003, available at http://www.triallawyersinc.com; cf. THOMAS F. BURKE, LAWYERS, LAWSUITS AND LEGAL RIGHTS, THE BATTLE OVER LITIGATION IN AMERICAN SOCIETY (2002); James D. Cox, The Social Meaning of Shareholder Suits, 65 BROOK. L. REV. 3 (1999); Anita Bernstein, The Enterprise of Liability, 39 VAL. U. L. REV. 27 (2004). On the federal courts' receptiveness to class action claims by individuals against national corporations, see EDWARD A. PURCELL, LITIGATION AND INEQUALITY: FEDERAL DIVERSITY JURISDICTION IN INDUSTRIAL AMERICA, 1870-1958 (Oxford University Press 1992) (studying changing litigation patterns and particular features of the federal courts' resolution of individuals' claims against national corporations). For recent empirical data documenting a nearly 100\% decrease in securities class action filings over the past two years, see reports of the Stanford Law School Securities Class Action Clearinghouse, available at http://securities.stanford.edu (evidence shows that class action lawsuits filed for securities fraud reached an all time low in 2006).

[iii]. Cox, 879 A.2d at 624 (praising reliance on Solomon standards rather than Lynch in recent court of chancery cases because this approach offers "the utility of providing a non-litigious route to effecting transactions that often were economically efficient both for the minority who received a premium and in a sense of creating more rationally organized corporations").

[iv]. Cox, 879 A.2d at 607 (proposing that its reforms would allow plaintiffs' lawyers to earn fees only by "actually prosecuting meritorious claims, and not by free riding on a special committee's work"). This negative view of the plaintiffs' bar was reinforced the summer after Cox was decided when the law firm Milberg Weiss Bershad \& Shulman was indicted, along with two of its partners, for allegedly making payments to plaintiffs in class action suits. See, e.g., Anthony Lin, Milberg Weiss, Two Partners Indicted in Kickback Probe, 235 N.Y.L.J., May 19, 2006, at 1. That summer (2006) Congress also considered a bill that would have imposed increased sanctions in cases where plaintiffs' lawyers' conduct in class actions had been adjudged too aggressive. See Securities Litigation Attorney Accountability and Transparency Act, H.R. 5491, 109th Cong. (2006).

[v]. This general issue was present in Tellabs, Inc. v. Makor Issues \& Rights, Ltd., 127 S.Ct. 2499, 2510 (2007) decided by the Supreme Court on June 21, 2007 (To qualify as "strong," as required by the Private Securities 
Litigation Reform Act of 1995, an inference of scienter must be more than merely plausible or reasonable-it must be "cogent and at least as compelling as any opposing inference of nonfraudulent intent.”). With respect to litigation touching on minorities' interests, there is substantial empirical evidence supporting a link between strong securities markets and robust legal protections for minorities. See, e.g., Michael S. Weisbach \& Willam A. Reese, Jr., Protection of Minority Shareholder Interests, Cross Listings in the United States and Subsequent Equity Offerings, 66 J. FIN. ECON. 65 (2002); Bernard S. Black, The Legal and Institutional Preconditions for Strong Securities Markets, 48 U.C.L.A. L. REV. 781 (2001); Rafael LaPorta, Florencio Lopez-de-Silanes, Andrei Shleifer \& Robert W. Vishny, Law and Finance, 106 J. POL. ECON. 1113 (1998) (finding least developed capital markets in countries providing the weakest protection to investors and minority owners).

[vi]. Both federal legislation and the Supreme Court's decisions have increasingly limited the scope of litigable claims by investors. See, e.g., Central Bank of Denver, N.A. v. First Interstate Bank, N.A., 511 U.S. 164, 201 (1994) (holding that no aiding and abetting liability applies under Rule 10b-5); Gustafson v. Alloyd Co., 513 U.S. 561 (1995) (affirming a very limited understanding of the term "prospectus" and thus substantially limiting the scope of the cause of action under Section 12(a)(2) of the Securities Act); Dura Pharm., Inc. v. Broudo, 544 U.S. 336 (2005) (holding that plaintiffs' purchase of securities at inflated price is insufficient to demonstrate loss causation). According to Professors Thompson and Thomas, the "focus of policy debate" shifted to limiting federal securities litigation once efforts to limit derivative litigation had proven largely successful. See Robert B. Thompson \& Randall S. Thomas, The New Look of Shareholder Litigation: Acquisition-Oriented Class Actions, 57 VAND. L. REV. 133, 136 (2004) [hereinafter “Thompson \& Thomas II”].

[vii]. Private Securities Litigation Reform Act of 1995, Pub. L. No. 104-67, 109 Stat. 737 (codified as amended at scattered sections in 15 U.S.C.) [hereinafter "PSLRA"]. For recent research on the role of lawyers and law firms in securities class actions, see Stephen J. Choi \& Robert B. Thompson, Securities Litigation and Its Lawyers: Changes during the First Decade After the PSLRA, 106 COLUM. L. REV. 1489 (2006).

[viii]. For analysis of these hurdles, see, e.g., James D. Cox, Making Securities Fraud Class Actions Virtuous, 39 ARIZ. L. REV. 497, 519-20 (1997) ( "The Reform Act's tightened pleading requirements and narrowed discovery rights more than any other feature probably account for any decline in the number of class action securities suits initiated since its enactment. As an effort to prevent the filing of a complaint from becoming the attorney's ticket to "flesh out” her pleadings through discovery, the Reform Act stays any discovery during the pendency of any motion to dismiss. The bar to discovery compounds the class action attorney's task in satisfying the Reform Act's heightened pleading standard.” (citations omitted)).

[ix]. Securities Litigation Uniform Standards Act of 1998, Pub. L. No. 105-353, 112 Stat. 3227 (codified as amended at scattered sections in 15 U.S.C.) [hereinafter "SLUSA"].

[x]. See, e.g., Merrill Lynch, Pierce, Fenner \& Smith, Inc. v. Dabit, 547 U.S. 71 (2006) (held that SLUSA bars class actions brought under state law even by persons claiming to have been misled into holding securities, as opposed to purchasing or selling them). For a thoughtful analysis of SLUSA's effects and the rationales invoked for its enactment, see Richard W. Painter, Responding to a False Alarm: Federal Preemption of State Securities Fraud Causes of Action, 84 CORNELL L. REV. 1 (1998).

[xi]. Sarbanes-Oxley Act of 2002, Pub. L. No. 107-204, 116 Stat. 745 (codified as amended at 15 U.S.C. §§ 720166 (Supp. IV 2004) and in scattered sections of 11 U.S.C., 28 U.S.C., and 29 U.S.C.) [hereinafter "SOX”].

[xii]. The exception is that in SOX, Congress restored the former, slightly longer statute of limitations for class actions alleging securities fraud. See SOX, supra note 56, § 804, 116 Stat. at 801 (codified at 28 U.S.C. § 1658 (Supp. IV 2004)).

[xiii]. The so-called "Delaware carve-out" preserves state jurisdiction over corporate fiduciary misrepresentation claims where plaintiffs allege that disclosure was presented to them in connection with a shareholder vote, in response to a tender or exchange offer, or in a context where appraisal rights were available. See SLUSA, supra note 
54, § 101(a)(1), 112 Stat. at 327-29 (codified at 15 U.S.C. § 77p (2000)) (amending section 16(d) of the 1933 Act). If Congress had not allowed for that safe harbor from preemption, then fiduciary suits against controllers for misrepresentation in freezeouts would not be litigable in equity.

[xiv]. For a thoughtful analysis of this mainstream, largely disapproving view of shareholder derivative actions, see Robert B. Thompson \& Randall S. Thomas, The Public and Private Faces of Derivative Lawsuits, 57 VAND. L. REV. 1747 (2004) [hereinafter “Thompson \& Thomas I"]. For consideration of the relative paucity of traditional derivative claims as a portion of the docket of the Delaware court of chancery, and comparatively greater number of class action claims contesting acquisitions, see Thompson \& Thomas II, supra note 51.

[xv]. See, e.g., Edward B. Rock \& Michael L. Wachter, Norms \& Corporate Law, 149 U. PA. L. REV. 1607 (2001) (providing an overview of scholarly work in the area of corporate law and norms); Edward B. Rock \& Michael L. Wachter, Islands of Conscious Power: Law, Norms and the Self-Governing Corporation, 149 U. PA. L. REV. 1619 (2001) (emphasizing the secondary role of law in corporate governance); but see Melvin A. Eisenberg, Corporate Law and Social Norms, 99 COLUM. L. REV. 1253 (1999) (providing a "thicker" account of the interplay between corporate law and corporate governance norms); Renee M. Jones, Law, Norms, and the Breakdown of the Board: Promoting Accountability in Corporate Governance, 92 IOWA L. REV. 105 (2006) (arguing that norms governance is less effective than scholars suggested pre-Enron, and proposing a scheme of proportionate liability to give corporate governance norms more traction). For a seminal, early analysis of norms governance in commercial communities, see Lisa Bernstein, Opting Out of the Legal System: Extralegal Contractual Relations in the Diamond Industry, 21 J. LEGAL STUD. 115 (1992).

[xvi]. DEBORAH DEMOTT, SHAREHOLDER DERIVATIVE ACTIONS: LAW AND PRACTICE (West 1999 \& Supp. 2007). See also Thompson \& Thomas I, supra note 59; Beam ex rel. Martha Stewart Living Omnimedia, Inc. v. Stewart, 845 A.2d 1040, 1049-52 (Del. 2004) (pre-suit demand on board not excused on account of mere existence of personal or business relationships among directors); Orman v. Cullman, 794 A.2d 5 (Del. Ch. 2002) (allowing application of business judgment rule instead of Entire Fairness standard in the context of a merger with an unaffiliated third party notwithstanding the presence of a controlling shareholder at the seller and the controller's continued involvement in the post-merger firm); Harbor Fin. Partners v. Huizenga, 751 A.2d 879 (Del. Ch. 1999) (granting motion to dismiss in claim against corporation's acquisition through merger, notwithstanding that four of seven directors had a conflict of interest, on the rationale that disinterested shareholders had ratified the transaction and the complaint failed to allege facts that would constitute "waste"); In reAquila, Inc. S'Holders Litig., 805 A.2d 184 (Del. Ch. 2002) (allowing business judgment deference to apply to the tender offer freezeout because the shareholders could freely choose whether or not to tender to the controller, notwithstanding that they had no independent advocate negotiate on their behalf in the offer); In reStaples, Inc. S'Holders Litig., 792 A.2d 934, 952 (Del. Ch. 2001) (denying permanent injunction against reclassification transaction involving conflicted directors, and affirming relevance of business judgment rule standard, but granting preliminary injunction to afford shareholders better disclosure).

[xvii]. The backlash against SOX is an expression of this policy perspective. See, e.g., Commission on the Regulation of U.S. Capital Markets in the $21^{\text {st }}$ Century, REPORT AND RECOMMENDATIONS 27-28 (March 2007) (produced by a Commission established by the U.S. Chamber of Commerce). For an account of the unfolding policy debate over amending or repealing portions of SOX, see Greg Ip, Kara Scannell \& Deborah Solomon, In Call to Deregulate Business, A Global Twist, WALL ST. J., Jan. 25, 2007, at A1. Even the Wall Street Journal noted the ambiguous evidence behind the claim that SOX is to blame for decreasing foreign listings on U.S. exchanges; the maturation of those foreign markets being a more plausible explanation.

[xviii]. Cox, 879 A.2d at 607 (proposed reforms would give "defendants the real option to get rid of cases on the pleadings ...”).

[xix]. The reforms proposed in the trilogy of freezeout cases analyzed herein are consonant with the themes addressed in many of Vice Chancellor Strine's other judicial and academic writings, in which he appeals for streamlining corporate legal doctrine under the business judgment rule. See, e.g., Allen, Jacobs \& Strine, supra note 
17; Leo E. Strine, Jr., If Corporate Action is Lawful, Presumably There Are Circumstances in Which it is Equitable To Take That Action: The Implicit Corollary to the Rule of Schnell v. Chris-Craft, 60 BUS. LAW. 877 (2005); Leo E. Strine, Jr., The Inescapably Empirical Foundations of the Common Law of Corporations, 27 DEL. J. CORP. L. $\underline{499(2002)}$.

$[\mathrm{xx}]$. For an account of this favorable view of corporate fiduciary doctrine-and the positive contribution of equitable adjudication, see, e.g., E. Norman Veasey \& Christine T. Di Guglielmo, What Happened in Delaware Corporate Law and Governance from 1992-2004? A Retrospective on Some Key Legal Developments, 153 U. PA. L. REV. $\underline{1399(2005)}$.

[xxi]. For a discussion of corporate fiduciary law's important role in supporting investors' capacity to trust in the legitimacy of the system of corporate governance see, e.g., Faith Stevelman Kahn, Transparency and Accountability: Rethinking Corporate Fiduciary Law's Relevance to Corporate Disclosure, 34 GA. L. REV. 505 (2000); Margaret M. Blair \& Lynn A. Stout, Trust, Trustworthiness, and the Behavioral Foundations of Corporate Law, 149 U. PA. L. REV. 1735 (2001); William T. Allen, Our Schizophrenic Conception of the Business Corporation, 14 CARDOZO L. REV. 261 (1992).

[xxii]. The term and concept are the author's.

[xxiii]. As defined in William J. Baumol \& Alan S. Blinder, Economics: Principles \& Policy 169 (7th ed. 1997), a public good is "a commodity or service whose benefits are not depleted by an additional user and for which it is generally difficult or impossible to exclude people from its benefits, even if the people are unwilling to pay for them."

[XXIV]. For discussion of choice of forum as a factor influencing substantive Delaware corporate legal doctrine, see Faith Stevelman, Regulatory Competition, Choice of Forum and Delaware's Stake in Corporate Law, 34 Del. J. Corp. L.57 (2009).

[164]. Solomon, 672 A.2d at 39.

[165]. Pure, 808 A.2d at 438 ("To begin with, the controlling stockholder is said to have no duty to pay a fair price, irrespective of its power over the subsidiary.”).

[166]. DEL. CODE tit. 8, § 262 (2007), amended by 76 Del. Laws ch. 145, §§ 11-16 (2007). For an analysis of the fair value standard relevant to appraisal actions, see Lawrence A. Hamermesh and Michael L. Wachter, The Fair Value of Cornfields in Delaware Appraisal Law, 31 J. CORP. L. 119 (2005); Brett A. Margolin and Samuel J. Kursh, The Economics of Delaware Fair Value, 30 DEL. J. CORP. L. 413 (2005); Barry M. Wertheimer, The Shareholder's Appraisal Remedy and How Courts Determine Fair Value, 47 DUKE L. J. 613 (1998); John C. Coffee, Jr., Transfers of Control and the Quest for Efficiency: Can Delaware Law Encourage Efficient Transactions While Chilling Inefficient Ones?, 21 DEL. J. CORP. L. 359 (1996).

[167]. Lynch, 638 A.2d at 1115 (citation omitted).

[168]. See generally Melvin Aron Eisenberg, Private Ordering Through Negotiation: Dispute Settlement and Rulemaking, 89 HARV. L. REV. 637 (1976).

[169]. FRANK H. EASTERBROOK \& DANIEL R. FISCHEL, THE ECONOMIC STRUCTURE OF CORPORATE LAW 146 (1991). For a discussion of investors' rational expectations regarding the trade-off of risk and return and their connection to appraisals standard of fair value, see Margolin \& Kursh, supra note 166, at 42627.

[170]. Margolin \& Kursh, supra note 166, at 426-27. 
[171]. For further explanation, see Gilson \& Gordon, supra note 5, at 787-88.

[172]. The academic literature has failed to address the increased risks for minorities arising from the three distinct legal schemes relevant to pricing in freezeouts. On the need for clarity in the appraisal standard itself-in the interest of protecting minorities' interests, reducing agency costs and hence reducing firms' cost of raising outside equity capital-see e.g. Margolin \& Kursh, supra note 166, at 415 ("Hence, corporate law's economic function is to reduce the firm's cost of equity capital through the governance of managerial malfeasance. Appraisal rights serve this purpose by preventing management from forcing the minority to tender its shares at less than Fair Value.”).

[173]. Solomon, 672 A.2d at 39.

[174]. See, e.g., Unocal Corp. v. Mesa Petroleum Co., 493 A.2d 946, 954 (Del. 1985).

[175]. See Pure, 808 A.2d at 446.

[176]. For a discussion of recent innovations in takeover defenses and their legal regulation, see David A. Katz, Takeover Law and Practice, 2006 (Wachtell, Lipton, Rosen \& Katz) (describing developments through November 8, 2006), available at http://www.ipba.org/calendar/documents/4d_David_katz Takeover_Law_and_Practice_2006-Asis_M\&A_Forum.PDF.

[177]. Id. This assumes a true majority controller. Where there is a de facto controller who owns less than absolute voting control, as was true in Cysive for example, then the freezeout would involve a "change in control," and Revlon duties should apply to the target board. For further discussion see Part V, intra. This issue has not been meaningfully discussed in the cases or the literature.

[178]. Hamermesh \& Wachter, supra note 166, at 120. See also Coffee, supra note 166, at 416 (proposing rule to protect minorities from controllers' exploitation of confidential information of target).

[179]. For the general point, see FRANK H. EASTERBROOK \& DANIEL R. FISCHEL, THE ECONOMIC STRUCTURE OF CORPORATE LAW (1991). For corporate fiduciary law's role in this regard, see Gilson \& Gordon, supra note 5, at 786-87. For appraisal's role in relation to controlling controller opportunism, see, e.g., Margolin \& Kursh, supra note 166, at 414-16. For an argument that pending but undisclosed alterations in the target's business model that prove profitable should be included in the fair value calculus in appraisals see Hamermesh \& Wachter, supra note 166, at 145-48. The contemporary analysis of agency costs reflects into the seminal work of Michael C. Jensen \& William H. Meckling, Theory of the Firm: Managerial Behavior, Agency Costs and Ownership Structure, 3 J. FIN. ECON. 305 (1976) (observing that agency costs arise once outside equity capital is used).

[180]. Professors Gilson and Gordon analyze the web of legal safeguards relevant to controllers' dealings affecting minorities as trading off the benefits of reduced managerial agency costs and controller's siphoning private benefits of control in their own interest. See Gilson \& Gordon, supra note 5, at 785-87, 843.

[181]. For further discussion of the myriad ways that controllers can obtain private profits from corporate controlmany of them legal or at least not remediable at law, see John C. Coates, "Fair Value" as an Avoidable Rule of Corporate Law: Minority Discounts in Conflict Transactions, 147 U. PA. L. REV. 1251, 1274 (1999).

[182]. See, e.g., Margolin \& Kursh, supra note 166, at 414-15.

[183]. DEL. CODE tit. 8, § 262 (2007), amended by 76 Del. Laws. ch. 145, §§ 11-16 (2007). 
[184]. For an excellent analysis of fair value in Delaware appraisals see, Hamermesh \& Wachter, supra note 166 (exploring the alternative notions of valuation in the case law on fair value in appraisals). For discussion of the appraisal statute and its role in corporate law, see Robert B. Thompson, Exit, Liquidity, and Majority Rule: Appraisal's Role in Corporate Law, 84 GEO. L. J. 1 (1995); see also Randall S. Thomas, Revising the Delaware Appraisal Statute, 3 DEL. L. REV. 1, 16-17 (2000) (describing narrow scope of appraisal and situations where appraisal rights should exist).

[185]. DEL. CODE. tit. 8, § 262(b) (2007), amended by 76 Del. Laws. ch. 145, §§ 11-12 (2007).

[186]. Ordinarily, the consideration in the short form merger would be cash; but this is not necessarily the case. Appraisal is unavailable where the consideration in the merger is shares in the acquire. Id. It is not uncommon for a tender offer freezeout to offer shares of the acquirer as consideration, as was true in Pure. Pure, 808 A.2d at 421.

[187]. DEL. CODE tit. 8, § 262(h) (2007), amended by 76 Del. Laws ch. $145 \S 14$ (2007). Cf. ABA MODEL BUS. CORP. ACT. § 13.02(a) (2005); Wertheimer, supra note 166, at 626-27 ("The statutory command in an appraisal proceeding is to find the 'fair value' of the dissenting shares, or sometimes the 'fair market value' or 'fair cash value.' Fair value is typically defined by statute as 'the value of the shares immediately before the effectuation of the corporate action to which the dissenter objects, excluding any appreciation or depreciation in anticipation of the corporate action.”' (citations omitted)).

[188]. DEL. CODE tit. 8, § 262(h) (2007), amended by 76 Del. Laws ch. 145 § 14 (2007).

[189]. These ambiguities reflect the changing nature of the appraisal remedy. At first appraisal seems to have been intended to facilitate the law's abandonment of the universal consent requirement for fundamental corporate changes, which had allowed minorities the ability to hold up value-enhancing mergers with third parties. The appraisal remedy eliminated such hold-up potential, while compensating the dissenting shareholders for what they lost, and providing them liquidity. Over time, appraisal has become more important in preventing oppression by controllers in cash-out mergers. For discussion of the changing nature of the appraisal remedy and its impact on the development of the fair value concept, see Wertheimer, supra, note 166.

[190]. This issue was litigated most notoriously in Cede \& Co. v. Technicolor, Inc. 684 A.2d 289 (Del. 1996). For discussion, see Jesse A. Finkelstein and Russell C. Silberglied, Technicolor IV: Appraisal Valuation in a Two-Step Merger, 52 BUS. LAW. 801 (1997).

[191]. For treatment of this issue, see Harmermesh and Wachter, supra note 166, at 138 (presenting the argument in favor of employing a definition of fair value that encompasses not only "the current asset stock and the return on those assets" but also the value arising from "reinvestment in new assets").

[192]. See, e.g., Paskill Corp. v. Alcoma Corp., 747 A.2d 549, 553 (Del. 2000) (affirming that appraisal's fair value concept presumes that the cashed-out shareholders would have maintained their investment had the merger not occurred).

[193]. For analysis and citation to the cases, see Hamermesh \& Wachter, supra note 166, at 137-39. For citation to extensive Delaware precedent employing going concern value as the benchmark for fair value, see id. at 132 n.56.

[194]. Tri-Continental Corp. v. Battye, 74 A.2d 71, 72 (Del. 1950) ("The basic concept of value under the appraisal statute is that the stockholder is entitled to be paid for that which has been taken from him, viz., his proportionate interest in a going concern.”).

[195]. Weinberger, 457 A.2d at 712-13. 
[196]. Id. at 713.

[197]. For cases dissecting the components of discounted cash flow ("DCF") see, e.g. In re Emerging Communications, Inc. Shareholders Litig., Cons. Civ. A. No. 16415, 2004 Del. Ch. LEXIS 70, at*43 (Del. Ch. May 3 , 2004) (“... the parties focus almost exclusively upon DCF valuation issues ... Accordingly this Opinion addresses only the valuation issues presented by the parties' competing DCF approaches.”); ONTI, Inc. v. Integra Bank, 751 A.2d 904, 917 (Del. Ch. 1999); and Grimes v. Vitalink Commc'ns Corp., Civ. A. No. 12334, 1997 Del Ch. LEXIS 124, at *3 (Del. Ch. Aug. 26, 1997) (observing that the DCF approach is "increasingly the model of choice for valuations in this Court”), clarified by 1997 Del. Ch. LEXIS 159 (Del. Ch. Sept. 17, 1997), aff'd, 1998 Del. LEXIS 127 (Del. Apr. 1, 1998). The DCF approach to defining going concern value was first endorsed by the court of chancery in Cede \& Co. v. Technicolor, Inc., Civ. A. No. 7129, 1990 Del. Ch. LEXIS 259 (Del. Ch. Oct. 19, 1990).

\section{[198]. The court stated:}

In determining what figure represents this true or intrinsic value, the appraiser and the courts must take into consideration all factors and elements which reasonably might enter into the fixing of value. Thus, market value, asset value, dividends, earnings prospects, the nature of the enterprise and any other facts which were known or which could be ascertained as of the date of merger and which throw any light on future prospects of the merged corporation are not only pertinent to an inquiry as to the value of the dissenting stockholders' interest, but must be considered by the agency fixing the value.

Weinberger, 457 A.2d at 713 (emphasis in original). [199]. Glassman, 777 A.2d at 248 (emphasis in original).

[200]. See Emerging Commc'ns, 2004 Del. Ch. LEXIS 70, at *83-84 (“... the market price of shares is not always indicative of fair value. Our appraisal cases so confirm.... Moreover, because Prosser always owned the majority interest, the market price of ECM stock always reflected a minority discount."); Hamermesh \& Wachter, supra note 166, at 132 ("If the shares' current market price were used to value the firm, the controller would be encouraged to under-manage, since the more it did so, the less it would have to pay for the minority interest in a squeeze out merger.”).

[201]. For a discussion of corporate valuation in which going concern value approximates financial economists' understanding of "fundamental value," see Michael L. Wachter, Takeover Defense When Financial Markets Are (Only) Relatively Efficient, 151 U. PA. L. REV. 787, 798 (2003) ("[T]he corporation's fundamental value is the sum of the free cash flows generated by the company's assets."). For further discussion of going concern value and DCF as a basis for valuation, see, e.g., RICHARD A. BREALEY, ET AL., PRINCIPLES OF CORPORATE FINANCE, at 509-511 (8th ed. 2006).

[202]. For a discussion of Pareto efficiency versus Kaldor Hicks efficiency and their relevance to corporate fiduciary law, see, e.g. Rutheford B. Campbell, Jr., A Positive Analysis of the Common Law of Corporate Fiduciary Duties, 84 KY. L. J. 455, 469-71 (1995-96) (proposing that corporate fiduciary law mandates managers to take all actions that "move corporate shareholders to Pareto superior states").

[203]. Id. This logic is distinct from that which bars a corporate fiduciary from profiting at a beneficiary's expense, as a mode of encouraging investment in the corporate form.

[204]. Observing the hurdles attendant to pursuing appraisal actions, commentators have noted the comparative paucity of appraisal actions since Weinberger affirmed the equitable cause of action arising under the Entire Fairness standard. See Gilson \& Gordon, supra note 5, at 789-99; Pure, 808 A.2d at 436 n.20 ("Another underpinning of the Lynch line of cases is an implicit perception that the statutory remedy of appraisal is a less than fully adequate protection for stockholders facing Inherent Coercion from a proposed squeeze out merger.”). 
[206]. SeeDEL. CODE tit. 8, § 262(b)(3) (2007). This limitation falls away if the controller compels a short-form merger under DEL. CODE tit. 8, § 253 (2007), however.

[207]. SeeDEL. CODE tit. 8, § 262(d) (2007).

[208]. SeeDEL. CODE tit. 8, § 262(a) (2007).

[209]. SeeDEL. CODE tit. 8, § 262(e) (2007), amended by 76 Del. Laws ch. 145, § 13 (2007).

[210]. SeeDEL. CODE tit. 8, § 262(g) (2007).

[211]. See Hamermesh \& Wachter, supra note 166, at 144 n.102 (“... the average appraisal proceeding lasts nearly four years.”).

[212]. SeeDEL. CODE tit. 8, § 262(a), (k) (2007), amended by 76 Del. Laws ch. 145, § 16 (2007).

[213]. SeeDEL. CODE tit. 8, § 262(a), (j) (2007).

[214]. Gilson \& Gordon, supra note 5, at 831-32.

[215]. Lynch, 638 A.2d at 1111 (noting that the plaintiff brought a class action on behalf of all shareholders of the acquired company whose stock had been procured through the merger).

[216]. Weinberger, 457 A.2d at 711;Lynch, 638 A.2d at 1115 (citing Weinberger).

[217]. Weinberger, 457 A.2d at 714.

[218]. The Delaware Supreme Court stated:

To summarize, in a section 262 appraisal action [under the DGCL] the only litigable issue is the determination of the value of the appraisal petitioners' shares on the date of the merger, the only party defendant is the surviving corporation and the only relief available is a judgment against the surviving corporation for the fair value of the dissenters' shares. In contrast, a fraud action asserting fair dealing and fair price claims affords an expansive remedy and is brought against the alleged wrongdoers to provide whatever relief the facts of a particular case may require. In evaluating claims involving violations of entire fairness, the trial court may include in its relief any damages sustained by the shareholders. See Rabkin, 498 A.2d at 1107; Weinberger, 457 A.2d at 713. In a fraud claim, the approach to determining relief may be the same as that employed in determining fair value under 8 Del. C. § 262. However, an appraisal action may not provide a complete remedy for unfair dealing or fraud because a damage award in a fraud action may include "rescissory damages if the [trier of fact] considers them susceptible of proof and a remedy appropriate to all issues of fairness before him." Weinberger, 457 A.2d at 714. Weinberger and Rabkin make this clear distinction in terms of the relief available in a section 262 action as opposed to a fraud in the merger suit.

Cede, 542. A.2d at 1187-88 (citations in the original). Compare Emerging Commc'ns, 2004 Del. Ch. LEXIS 70, at *94-95 (noting that in an appraisal the court may compute a prejudgment interest award to effect disgorgement by the acquirer of any benefit obtained from the use of the funds, as well as the lost time value of the money; citing Cede \& Co. JRC Acquisitions Corp., No. 18648, 2004 WL 286963, at*12 (Del. Ch. Feb. 10, 2004)).

[219]. SeeDEL. CODE tit. 8, § 262(i) (2007).

[220]. SeeDEL. CODE tit. 8, § 262(j) (2007). 
[222]. See e.g. Guth v. Loft, 5 A.2d 503, 510-11 (Del. 1939) ("[I]f, in such circumstances, the interests of the corporation are betrayed, the corporation may elect to claim all of the benefits of the transaction for itself, and the law will impress a trust in favor of the corporation upon the property, interests and profits so acquired; ... a constructive trust is the remedial device through which precedence of self is compelled to give way to the stern demands of loyalty."); see also Eric G. Orlinsky, Corporate Opportunity Doctrine and Interested Director Transactions: A Framework for Analysis in an Attempt to Restore Predictability, 24 DEL. J. CORP. L. 451, 524-25 (1999).

[223]. SeeOberly v. Kirby, 592 A.2d 445, 463 (Del. 1991) ("It is an act of disloyalty for a fiduciary to profit personally from the use of information secured in a confidential relationship, even if such profit or advantage is not gained at the expense of the fiduciary. The result is nonetheless one of unjust enrichment which will not be countenanced by a Court of Equity.”); see alsoBrophy v. Cities Service Co., 70 A.2d 5, 7-8 (Del. Ch. 1949).

[224]. Weinberger, 457 A.2d at 714 (“... a plaintiff's monetary remedy ordinarily should be confined to the more liberalized appraisal proceeding herein established, we do not intend any limitation on the historic powers of the Chancellor to grant such relief as the facts of a particular case may dictate.”).

[225]. See, e.g., Fleigler v. Lawrence, 361 A.2d 218, 221 (Del. 1976) (requiring controller/director to establish that sale of assets to corporation was beneficial to the minority/corporation, in order to meet the fair price criteria of the Entire Fairness standard).

[226]. Weinberger, 457 A.2d at 709 n.7.

[227]. Id. at 711 .

[228]. In the terminology employed by Professors Gordon and Gilson, the fair price element of the Entire Fairness standard ensures the minority a price that reflects the outcome of bargaining in a bilateral monopoly, where a deal doesn't happen unless the welfare of each party is improved. Gilson \& Gordon, supra note 5, at 804.

[229]. SeeDEL. CODE tit. 8, § 262(h) (2007), amended by 76 Del. Laws ch. 145, § 14 (2007).

230]. Weinberger, 457 A.2d at 713. To emphasize the narrowness of this exclusion the opinion provides: "We take this to be a very narrow exception to the appraisal [valuation] process, designed to eliminate the use of pro forma data and projections of a speculative variety relating to the completion of a merger." Id. Again, as Professors Hamermesh and Wachter have illuminated in their discussion of "fair value" valuation, going concern value in an appraisal should not allocate any synergy-specific gains from the merger to the minority. Hamermesh \& Wachter, supra note 166, at 148-50.

[231]. Weinberger, 457 A.2d at 713.

[232]. Gilson \& Gordon, supra note 5, at 785 (arguing that an equivalent degree of rigor should apply in the fiduciary standards that shape controllers' receipt of private benefits in operating decisions, sales of control and freezeouts).

[233]. The reforms proposed to cash-out mergers are analyzed in Part IV, infra.

[234]. Pure, 808 A.2d at 445. The accommodation proposed in Pure, as supplemented by Cox, essentially mirrors the approach proposed by Subramanian, Fixing Freezeouts, supra note 5, at 8 ("Translating the arms-length standard 
to the freezeout arena requires, first, meaningful approval by [a special committee] of independent directors; and second, approval by a majority of the minority shareholders. When both of these procedural protections are provided, this Article proposes that courts should apply deferential business judgment review to assess the transaction.”). See also Gilson \& Gordon, supra note 5, at 786, 838-39.

[235]. Pure, 808 A.2d at 445;Cox, 879 A.2d at 606.

[236]. Pure, 808 A.2d at 445;Cox, 879 A.2d at 606.

[237]. Pure, 808 A.2d at 445;Cox, 879 A.2d at 606.

[238]. See Cox, 879 A.2d at 623.

[239]. Solomon, 672 A.2d at 36-37.

[240]. Id. at 38-39.

[241]. Id. at 39 .

[242]. Id. at 37. Given the factual circumstances noted in the opinion, it is likely that the bank's tender offer was intended to push its ownership over the $90 \%$ threshold, so that it would be able to obtain a higher price in the sale of Pathe's stock by conveying to a third party the right to execute a short-form merger-but that, like other important features of the case, is not discussed in the Delaware Supreme Court's opinion.

[243]. Id. at 39.

[244]. Id. at 39. Earlier in the opinion the complaint is described as alleging a breach of loyalty against the controller, based on the "coercive" tender offer price. Id. at 37.

[245]. Id. at 39. For a discussion of the standards relevant to dismissal of a shareholder complaint in a class action against a controller, see Rabkin v. Philip A. Hunt Chem. Corp., 498 A.2d 1099, 1104 (Del. 1985) (in order to sustain a motion to dismiss a complaint for failure to state a claim, the court must conclude, with reasonable certainty, that the plaintiff cannot prevail and would not be entitled to the relief sought under any set of facts that could be proven to support the claims).

[246]. Solomon, 672 A.2d at 39.

[247]. See, e.g., Smith v. Van Gorkom, 488 A.2d 858, 877 (Del. 1985) ("Here, the issue is whether the directors informed themselves as to all the information that was reasonably available to them.”).

[248]. Solomon, 672 A.2d at 39.

[249]. See infra notes 314-32 and accompanying text.

[250]. Solomon, 672 A.2d at 39 .

[251]. For court of chancery opinions addressing the fair price issue, see $\underline{I n}$ re Ocean Drilling \& Exploration Company S'holders Litig., Civ. A. No. 11898, 1991 WL 70028, at *3 (Del. Ch. Apr. 30, 1991) (concluding that "as a general principle our law holds that a controlling shareholder extending an offer for minority-held shares in the controlled corporation is under no obligation, absent evidence that material information about the offer has been 
withheld or misrepresented or that the offer is coercive in some significant way, to offer any particular price for the minority-held stock"); Joseph v. Shell Oil Co., 482 A.2d 335, 341 (Del. Ch. 1984) (holding that in the absence of fraud minorities are generally allowed to decide for themselves whether to tender to a controller). An earlier Delaware Supreme Court decision, Lynch v. Vickers Energy Corp., 383 A.2d 278, 279 (Del. 1978), ruled on the adequacy of a controller's disclosures in a tender offer but did not address whether a fair price duty applied in the transaction.

[252]. 672 A.2d at 39 (citing Lynch v. Vickers Energy Corp. 351 A.2d 570, 576 (Del. Ch. 1976), rev'd on other grounds, 383 A.2d 278 (Del. 1977); Weinberger v. UOP, Inc., 457 A.2d 701, 703 (Del. 1983)).

[253]. Lynch v. Vickers Energy Corp., 351 A.2d 570 (Del. Ch. 1976), rev'd, 383 A.2d 278 (Del. 1977). The decision to which the Solomon court refers is the earlier Delaware Court of Chancery case. Solomon, 672 A.2d at 39. The precise language in Vickers Energy which the Solomon court relies upon is as follows:

There is no provision in the Delaware Corporation Law and it would not be appropriate under equitable principles, in my opinion, to bind an offeror in a situation such as the one at bar to an implied commitment to pay an additional consideration for tendered shares in an amount made up of the difference between the price offered and what might ultimately be found to be the intrinsic value of the shares in question.

Vickers Energy, 351 A.2d at 576 (cited in Solomon, 672 A.2d at 39). The additional consideration was precisely the award made by the Delaware Supreme Court in the second appeal once the plaintiffs had proven lack of candor on the controller's part. SeeLynch v. Vickers Energy Corp., 429 A.2d 497, 503 (Del. 1981).

[254]. Weinberger, 457 A.2d at 711.

[255]. Id.; Lynch v. Vickers Energy Corp., 383 A.2d 278, 281 (Del. 1977) (holding controllers to a standard of "complete candor" rather than mere adequacy in their tender offer disclosures, in light of their opportunity to exploit 'special knowledge' they gained as insiders, to the offerees' detriment).

[256]. See Solomon, 672 A.2d at 39.

[257]. Id.

[258]. Id. (citing Eisenberg v. Chicago Milwaukee Corp., 537 A.2d 1051, 1056 (Del. Ch. 1987) (providing a rare treatment of the features which would constitute coercion in this setting)). For further discussion of the Delaware case law on inequitable coercion, see, e.g., Dennis J. Block and Jonathan M. Hoff, The Doctrine of Inequitable Coercion under Delaware Law, 221 N.Y.L.J. 5 (Apr. 22, 1999).

[259]. Pure, 808 A.2d at 445-46.

[260]. Solomon, 672 A.2d 39-40.

[261]. See In reUnocal Exploration Corp. S'holders Litig., 793 A.2d 329, 338 n.26 (Del. Ch. 2000), aff'd sub nom., Glassman v. Unocal Exploration Corp., 777 A.2d 242 (Del. 2001).

[262]. Schnell v. Chris Craft Indus., Inc., 285 A.2d 437, 439 (Del. 1971) ("Inequitable conduct does not become permissible simply because it is legally possible.”).

[263]. See, e.g., Blasius v. Atlas Indus. Inc., 564 A.2d 651 (Del. Ch. 1988) (actions by board after consent solicitation had begun, designed for purpose of thwarting a shareholder vote, held to violate fiduciary duties despite their conformity with statutory provisions, consistent with Schnell).

[264]. DEL. CODE tit. 8, § 253 (2007). 
[265]. Lynch, 638 A.2d at 1118 ("Once again, this Court holds that the exclusive standard of judicial review in examining the propriety of an interested cash-out merger transaction by a controlling or dominating shareholder is entire fairness.”). The Lynch decision nowhere expressly discussed short-form mergers, however.

[266]. Stauffer v. Standard Brands Inc., 187 A.2d 78 (Del. 1962), overruled in part byRoland Intern. Corp. v. Najjar, 407 A.2d 1032 (Del. 1979).

[267]. Id. at 80 .

[268]. Glassman v. Unocal Exploration Corp., 777 A.2d 242, 247-48 (Del. 2001).

[269]. Glassman, 777 A.2d at 247-48 ("The equitable claim plainly conflicts with the statute. If a corporate fiduciary follows the truncated process authorized by $\S 253$, it will not be able to establish the fair dealing prong of entire fairness. If, instead, the corporate fiduciary sets up negotiating committees, hired independent financial and legal experts, etc., then it will have lost the very benefit provided by the statute.”).

[270]. Id. at 248 .

[271]. Id.

[272]. DEL. CODE tit. 8, § 253 (2007).

[273]. Glassman, 777 A.2d at 247-48.

[274]. For a discussion of the residual ambiguity in the opinion, see Marc I. Steinberg, Short-Form Mergers in Delaware, 27 DEL. J. CORP. L. 489 (2002).

[275]. See In re Unocal, 793 A.2d at 338 n.26.

[276]. But see In re Life Tech., Inc. S'holders Litig., No. C.A. 16513, 1998 WL 1812280 (Del Ch. Nov. 24, 1998). The case is noted and discussed in Letsou \& Haas, supra note 113, at 45.

[277]. In fact, the controller remained somewhat indecisive about its intention to complete the short-form merger. The effect of that, however, was to make the target stockholders' decision to refuse to tender more perilous, because appraisal rights would not be triggered without a short-form merger. In re Siliconix, Inc. S'holders Litig., C.A. No. 18700, 2001 WL 716787, at*2 (Del. Ch. June 19, 2001).

[278]. Id. at *15 ("I now turn to the instances alleged by Fitzgerald to constitute actionable coercion.”). Prior to Siliconix, the most telling case on the question of what "pressure" from controllers constituted "coercion" in equity was Eisenberg v. Chicago Milwaukee Corp., 537 A.2d 1051, 1056 (Del. Ch. 1987).

[279]. Siliconix, $2001 \mathrm{WL} 716787$, at *2,*4-5. Siliconix's stock price and product performance were showing signs of a rebound at the time of the buyout offer; however, the stock's price had advanced only slightly from its recent historic low.

[280]. Id. at *1.

[281]. Id. at $* 2$. 
[282]. Id.

[283]. Id.

[284]. Id. at *16 (finding that this declaration, too, was not coercive).

[285]. Id. at *12.

[286]. Id.

[287]. For the discussion of the fiduciary disclosure requirement, see id. at *9-14.

[288]. Id. at *2.

[289]. Id.

[290]. Id.

[291]. Id.

[292]. Id.

[293]. Id.

[294]. Id.

[295]. Id. at *2 n.4.

[296]. Id. at *3.

[297]. Id. at *3 \& $n .7$ (the court called attention to the $\$ 1.75$ million fee to be paid to Lehman, the special committee's advisers, upon the closing of the transaction).

[298]. Id. at *3.

[299]. Id. at *6 ("However, this Court will intervene to protect the rights of the shareholders to make a voluntary choice."). Compare Solomon, 672 A.2d at 39 ("In the case of totally voluntary tender offers, as here, courts do not impose any right of the shareholders to receive a particular price." (citations omitted)), with Siliconix, 2001 WL 716787, at *15 ("A tender offer is coercive if the tendering shareholders are 'wrongfully induced by some act of the defendant to sell their shares for reasons unrelated to the economic merit of the sale.' The wrongful acts must 'influence in some material way' the shareholder's decision to tender. I now turn to the instances alleged by Fitzgerald to constitute actionable coercion.” (citations omitted)).

[300]. Siliconix, $2001 \mathrm{WL} 716787$, at *12.

[301]. Id. at *5 (“... [The Schedule 14D-9] reported that the Special Committee has determined to remain neutral and make no recommendation with respect to the tender offer. The special committee never requested Lehman to prepare a fairness opinion as to the exchange offer.”). 
[302]. Id.

[303]. Id. at $* 2$. The controller set its opening cash bid at a $10 \%$ cash premium over the market trading price of Siliconix stock-a relatively low premium which was, moreover, twenty percent below the average trading price of the stock in the six months prior to the bid. The court states that Vishay made "no effort to value Siliconix." Id. For facts relating to the switch to stock, see id. at *4.

[304]. Id. at *4 ("Unlike the February 22 cash tender announcement, the share exchange carried no market premium for the Siliconix shareholder.”).

[305]. See id. at *4.

[306]. Id. at *4.

[307]. Id. at *17.

[308]. Id. at *6 ("The issue of voluntariness of the tender depends on the absence of improper coercion and the absence of disclosure violations.... Accordingly, Vishay was under no duty to offer any particular price, or a 'fair' price to the minority shareholders of Siliconix unless actual coercion or disclosure violations are shown by Fitzgerald.” (emphasis added)).

[309]. See, e.g., id. at *2 n.4 ("It is not disputed that all Siliconix directors, because of their deep involvement with Vishay suffered serious conflicts of interest (except for those directors Segall and Talbert, about whose independence there is debate).”).

[310]. Id. at *7 ("[i]t may seem strange that the scrutiny given to tender offer transactions is less than the scrutiny given to, for example, a merger....”).

[311]. See Vickers Energy, 383 A.2d at 279;Malone v. Brincat, 722 A.2d 5, 11 (Del. 1998). For an analysis of the evolution of Delaware's fiduciary disclosure doctrine, see Hamermesh, Calling Off the Lynch Mob, supra note 99. For further commentary, see Kahn, Transparency and Accountability, supra note 66; Jennifer O'Hare, Director Communications and the Uneasy Relationship Between the Fiduciary Duty of Disclosure and the Anti-Fraud Provisions of the Federal Securities Laws, 70 U. CIN. L. REV. 475 (2002).

[312]. Siliconix, 2001 WL 716787, at *14 ("In conclusion, I have not found that, on this preliminary record, Fitzgerald had made the necessary showing to establish any disclosure violation."); id. at *9 ("In the context of a preliminary injunction proceeding regarding a tender offer, the issue becomes whether there is a reasonable probability that a material omission or misstatement has been made 'that would make a reasonable shareholder more likely to tender his shares.”' (Citations omitted.)).

[313]. Id. at *12.

[314]. Id. at *7 ("Indeed, the board of the tender target is not asking its shareholders to approve any corporate action by the tender target. That, however, does not mean that the board of the company to be acquired in a tender has no duties to the shareholders.”).

[315]. Id. at *1.

[316]. Id. at *2-3, *5. 
[317]. Id. at *8-9.

[318]. Id. at *6.

[319]. Id. at *6.

[320]. Id. at *7-8.

[321]. Siliconix, 2001 WL 716787, at*8 (distinguishing the Delaware Supreme Court's expansive view of directors' duties in McMullin on the basis that those duties "were statutory duties imposed by 8 Del. C. § 251”). SeeMcMullin v. Beran, 765 A.2d 910 (Del. 2000).

[322]. See, e.g., Pure, 808 A.2d at 434.

[323]. Siliconix, 2001 WL 716787, at *7 (“... the target company in the tender context does not confront a comparable corporate decision [to a merger].”).

[324]. See supra note 158.

[325]. Siliconix, 2001 WL 716787, at*8 (citing McMullin v. Beran, 765 A.2d 910 (Del. 2000)).

[326]. McMullin v. Beran, 765 A.2d 910, 920 (Del. 2000) (motion to dismiss for failure to state a claim reversed and remanded).

[327]. Siliconix, $2001 \mathrm{WL} 716787$, at* 8.

[328]. Id.

[329]. McMullin, 765 A2d. at 921.

[330]. This same principle is enunciated earlier in Smith $v$. Van Gorkom, in relation to directors' duties in a sale by merger to a third party. SeeSmith v. Van Gorkom, 488 A.2d 858 (Del. 1985).

[331]. $2001 \mathrm{WL} 716787$, at *7 ("Indeed, the board of the tender target is not asking its shareholders to approve any corporate action by the tender target. That, however, does not mean that the board of the company to be acquired in a tender has no duties to the shareholders.”).

[332]. Id. at *8. In Siliconix, the court expressed the view that it would have to endorse "a new approach to assessing the conduct of directors of a tender target" if it were to rule in plaintiffs' favor. The court said that it would have to overrule cases such as Solomon to validate an active defensive role for target directors. Id.

[333]. Pure, 808 A.2d at $446-332$.

[334]. See supra text accompanying notes 276-332.

[335]. In reAquila, Inc. S'holders Litig., 805 A.2d 184, 190-91 (Del. Ch. 2002).

[336]. See infra notes 350-84 and accompanying text. 
[337]. Pure, 808 A.2d at 450.

[338]. Id. at 430 .

[339]. Id. at 424-25.

[340]. Id. at 425 .

[341]. See id. at 449-51.

[342]. Id. at 446.

[343]. 808 A.2d at 452 (“... an injunction can be issued that can be lifted in short order if Unocal and the Pure board respond to the concerns addressed in this opinion.”).

[344]. Id.

[345]. On October 30, 2002 (one month after the court of chancery's decision in Pure) Unocal closed its short-form merger finalizing its acquisition of Pure. The exchange offer had closed the previous night at midnight. See Unocal Press Release archives, Unocal completes acquisition of Pure Resources (Oct. 30, 2003), available at http:// www.chevron.com/news/archive/unocal_press/release.aspx?id=2002-10-30a.

[346]. Pure, 808 A.2d at 425-26.

[347]. Id.

[348]. Id. at 426-27.

[349]. Id. at 426-28.

[350]. Id. at 427.

[351]. Id.

[352]. Id. at 428-29.

[353]. Id. at 427.

[354]. Id.

[355]. Id. at 426.

[356]. Id.

[357]. Id. at 428.

[358]. See id. at 425-26. On the indeterminate effect of a conflicted board's approval of a merger agreement, see Krasner v. Moffett, 826 A.2d 277, 285 (Del. 2003) (noting the dilemma posed by statute's prohibition on assent to a merger by a committee where nearly the entire board was affected by material conflicts of interest in a merger). 
[359]. See supra Part II, D.

[360]. For the conditions Unocal agreed to abide by in its offer, see Pure, 808 A.2d at 430 . By the time of its opinion in Pure, the court of chancery was able to refer to a "line of cases" under which a controller's observance of certain terms would demonstrate that the freezeout tender offer was noncoercive. Id. at 438.

[361]. Id. at 429, 431.

[362]. Id.

[363]. Id. at 426.

[364]. For the denial of the waiver, see id. at 432 n.9; for previous grants of the waiver, see id. at 427 ("Unocal granted these waivers in each case.”).

[365]. Id. at 429 (noting that Unocal affiliated directors "Maxwell and Laughbaum did not recuse themselves generally from the Pure board's process of reacting to the Offer").

[366]. Id. at 430-31.

[367]. See id.

[368]. Id.

[369]. This becomes evident principally in relation to the court's discussion of the disclosure deficiencies relating to the Schedule 14D-9, id. at 450-51.

[370]. Id. at 431.

[371]. Id.

[372]. Pure, 808 A.2d at 432 (“... on September 17, 2002 the Special Committee voted not to recommend the Offer, based on its analysis and the advice of its financial advisors").

[373]. Id. at 438-39.

[374]. Id. at 430 .

[375]. Id. at 446-47.

[376]. Id. at 430 .

[377]. It is not clear how withdrawal rights would or would not protect minorities in this case. For the regulation affording minorities withdrawal rights in tender offers, see supra note 147 and accompanying text.

[378]. Pure, 808 A.2d at 430, 432.

[379]. Id. at 432. 
[380]. See infra Part III, C.

[381]. Pure, 808 A.2d at 429 (“... we are not interested in selling our shares in Pure”).

[382]. Id. at 450.

[383]. Id. The court requires amendments to these disclosures, but they may have influenced the course of the transaction nevertheless.

[384]. Id. at 432.

[385]. Id. at 430.

[386]. Id. at 429.

[387]. Id. at 445.

[388]. Id. at 444 ("To the extent that my decision to adhere to Solomon causes some discordance between the treatment of similar transactions to persist, that lack of harmony is better addressed in the Lynch line, by affording greater liability-immunizing effect to protective devices such as majority of the minority approval conditions and special committee negotiation and approval.”). For discussion of Cox's broad based plan to overhaul freezeout doctrine, see infra Part IV.

[389]. See, e.g., Subramanian, Fixing Freezeouts, supra note 5, at 8 (concluding that where a special committee and majority of the minority shares have ratified a freezeout, deferential review rather than the Entire Fairness standard is warranted); Letsou \& Haas, supra note 113, at 29 (adopting analogous approach though with greater emphasis on the controller's disclosure duties).

[390]. See, e.g., Gilson \& Gordon, supra note 5, at 838.

[391]. Pure, 808 A.2d at 444 (“.... the preferable policy choice is to continue to adhere to the more flexible and less constraining Solomon approach ...”).

[392]. Id.

[393]. Id. at 445. Apart from these equitable requirements, controllers have extensive disclosure obligations, consistent with established fiduciary requirements and federal securities' law mandates, of course. These are addressed in a separate portion of the Pure opinion. Id. at 447-52.

[394]. Id. at 437-39.

[395]. Id. at 435-37.

[396]. Id. at 439-41.

[397]. See, e.g., Gilson \& Gordon, supra note 5, at 826 ("Properly understood, the Pure resolution is an important, yet still incomplete, step toward restoring a desirable coherence in this area.").

[398]. See, e.g., Gilson \& Gordon, supra note 5, at 817 (critique of the improper loosening of standards effectuated 
by Siliconix and Aquila for tender offer freezeouts).

[399]. Pure, 808 A.2d at 437-39.

[400]. In re Siliconix Inc. S'holders Litig., No. 18700, 2001 WL 716787, at *8 (Del. Ch. June 19, 2001) (citing as a rationale for its holding the belief that an alternative finding would have required it to "overrule" Solomon).

[401]. In reAquila, Inc., 805 A.2d 184, 190 (Del. Ch. 2002).

[402]. See supra Part III, A.1 and 2.

[403]. Pure, 808 A.2d at 438 ("The inherent coercion that Lynch found to exists when controlling stockholders seek to acquire the minority's stake is not even a cognizable concern for the common law of corporations if the tender offer method is employed.”).

[404]. Id. at 441 ("The problem is that nothing in the tender offer method of corporate acquisition makes the 800pound gorilla's retributive capabilities less daunting to minority stockholders. Indeed, many commentators would argue that the tender offer form is more coercive than a merger vote.”)

[405]. There reforms address informational, organizational and timing issues, but not inherent coercion. $\underline{\text { Pure, } 808}$ A.2d at 445 .

[406]. Id.

[407]. Solomon, 672 A.2d at 39.

[408]. See Pure, 808 A.2d at 441.

[409]. See infra Part III, C.

[410]. Pure, 808 A.2d at 441-42.

[411]. Id. at 443 ("The [Solomon] approach also minimizes the potential for the minority to get the best price, by arguably giving them only enough protection to keep them from being structurally coerced into accepting grossly insufficient bids but not necessarily merely inadequate ones."). See also id. at 444 ("The preferable policy choice is to continue to adhere to the more flexible and less constraining Solomon approach..."); $\underline{i d}$. at 437 ("The policy balance struck in Lynchcontinues to govern negotiated mergers between controlling stockholders and subsidiaries.”)

[412]. Id. at 443. Pure expressly owns this "policy" basis for its reforms at certain points, for example in its observation that the two lines of freezeout doctrine reflect "a difference in policy emphasis that is far greater than can be explained by the technical differences between tender offers and negotiated mergers ....” Id.

[413]. Id. at 434 (stating that judges inevitably make normative choices in conditions of imperfect information).

[414]. See id.

[415]. Id. at 443-44.

[416]. Id. at 435-36, 441-44. 
[417]. Id. at 442.

[418]. Id. at 442-44.

[419]. Id. at 444-45.

[420]. 493 A.2d 946, 949 (Del. 1985).

[421]. 500 A.2d 1346, 1355 (Del. 1985).

[422]. See Pure, 808 A.2d at 439. For further discussion of this issue, see Gilson \& Gordon, supra note 5, at 820-22.

[423]. Pure, 808 A.2d at 446.

[424]. Id. at 430-31.

[425]. SeeDEL. CODE tit. 8, § 141(c)(2) (2007).

[426]. See supra note 89 and accompanying text; Freedman v. Restaurant Assocs. Indus., Inc., Civ. A. No. 9212, 1990 WL 135923, at *6 (Del. Ch. Sept. 21, 1990).

[427]. See Freedman, 1990 WL 135923, at *6-7.

[428]. Pure, 808 A.2d at 431.

[429]. Id. at 446.

[430]. Id. See, e.g., Moran, 500 A.2d at 1355.

[431]. Pure, 808 A.2d at 445.

[432]. Id.

[433]. Weinberger, 457 A.2d at 709.

[434]. See Gilson \& Gordon, supra note 5, at 838.

[435]. 808 A.2d at 445.

[436]. Lynch, 638 A.2d at 1113. In Lynch the committee's choices were further constrained by the controller's power to block third party offers that received approval by less than $80 \%$ of the voting shares. The subsidiary's law firm had proposed and explored adoption of a poison pill or the search for a "white knight" bidder but found both "unfeasible" in light of the controller's blocking power. See id. at 1113 n.3.

[437]. Pure, 808 A.2d at 445.

[438]. Id.

[439]. It is important to note that neither the recent cases nor this Article propose new requirement for controllers to 
proceed in freezeouts. What is at stake is the standard of review.

[440]. SeeDEL. CODE tit. 8, § 251(c) (2007), amended by 76 Del. Laws ch. 145 §§ 4-5 (2007).

[441]. In re Emerging Commc'ns, 2004 Del. Ch. LEXIS 70, at*114-15 ("Nor should a tender offer be treated as the equivalent of an informed vote.”).

[442]. Pure, 808 A.2d at 442-43.

[443]. See supra note 146.

[444]. On the phenomenon of "salience," as it may affect investor psychology, see, e.g., Cass R. Sunstein, What's Available? Social Influences and Behavioral Economics, 97 NW. U. L. REV. 1295 (2003) (analyzing social influences that make certain forms of risk salient or "cognitively available" and their relevance to law).

[445]. In addition, brokers earn commissions on shareholders' decisions to tender (these are stock sales), but no commissions are earned by brokers if minorities retain their shares.

[446]. See supra notes 204-13 and accompanying text.

[447]. 777 A.2d at 248.

[448]. DEL. CODE tit. 8 § 253 (2007).

[449]. Pure, 808 A.2d at 445.

[450]. Id.

[451]. Id. The Delaware Supreme Court declined to hear an appeal filed in the case. See Pure, 808 A.2d 421 (Del. Ch. 2002), appeal refused, 2002 Del. LEXIS 630 (Del. Oct. 10, 2002).

[452]. In Pure itself there were mixed signals sent to the minority shareholders about the $90 \%$ minimum tender condition. Unocal initially announced that its offer was "conditioned on the tender of a sufficient number of shares of Pure common stock such that, after the offer is completed, we will own at least $90 \%$ of the outstanding shares of Pure common stock...." Pure, 808 A.2d at 429. However, in describing the key terms of the Unocal offer as presented to the special committee, the court noted the inclusion of "a waivable condition that a sufficient number of tenders be received to enable Unocal to own $90 \%$....” Id. at 430 (emphasis added).

[453]. See Pure, 808 A.2d at 444.

[454]. See, e.g., Rabkin v. Olin Corp., C.A. No. 7547, 1990 WL 47648, at*12 (Del. Ch. Apr. 17, 1990), aff'd, 586 A.2d 1202 (Del. 1990) (Where the controller waited until immediately after a price agreement had expired to eliminate the minority, the court of chancery held, consistent with Lynch's Entire Fairness standard, that such precise tactical maneuvering was incompatible with the duty of fair dealings.).

[455]. See, e.g., Emerging Commc'ns, 2004 Del. Ch. LEXIS 70, at*111 (ruling that tender offer freezeout was a self-dealing transaction because the controller was at both sides, so that Entire Fairness was the proper standard of review). The self-dealing nature of the transaction would be mitigated if there were truly a majority of independent directors, i.e. if there was only a de facto controller. But then Revlon duties would apply. See infra note 501 and accompanying text. 
[456]. See, e.g., Weinberger, 457 A.2d. at 703 ("But in all this, the burden clearly remains on those relying on the vote to show that they completely disclosed all material facts relevant to the transaction.”).

[457]. 383 A.2d at 280 ("The court's duty was to examine what information defendants had and to measure it against what they gave to the minority stockholders, in a context in which "complete candor” is required.”).

[458]. Cox, 879 A.2d at 607 ("That is, in the context of going-private transactions implemented by tender offers by controlling stockholders-so called Siliconix transactions-the protections of Pure Resources should be supplemented by subjecting the controlling stockholder to the entire fairness standard if a special committee recommended that the minority not tender." (citations omitted)); compare id. at 645 ("In the case of a tender offer by a controlling stockholder, the controlling stockholder could be relieved of the burden of proving entire fairness if: 1) the tender offer was recommended by an independent special committee; 2) the tender offer was structurally non-coercive in the manner articulated by Pure Resources; and 3) there was disclosure of all material facts.”).

[459]. Pure, 808 A.2d at 445.

[460]. See Cox, 879 A.2d at 607.

[461]. Pure, 808 A.2d at 426, 429.

[462]. Id. at 431.

[463]. Id. at 445 .

[464]. Id. at 446.

[465]. Id. at 432 .

[466]. Id. at 445 .

[467]. Cox, 879 A.2d at 607, 645 .

[468]. Id.

[469]. Whether read as an approval requirement or a requirement of nondisapproval, it is clear that Cox is proposing that a special committee's disapproval would trigger the Entire Fairness standard for the tender offer freezeout. Id. at 607 (the "nondisapproval” requirement) and 645 (the approval requirement).

[470]. Id.

[471]. At times Cox describes the special committee's role in negotiating the freezeout, in addition to approving of it, as a condition to deferential review. Id. at 643-44. However, as part of this negotiating power Cox nowhere proposes that the special committee be allowed defensive authority to block the bid while it considers alternatives. In the absence of such plenary defensive power and the attendant capacity to consider alternative proposals, it is difficult to make sense of what genuine negotiating authority means.

[472]. Id. at 607, 645 (this is evident from Cox's failure to address a committee's defensive authority or even negotiating role in a tender offer freezeout). 
[473]. Id. at 607 (the "nondisapproval” requirement) and 645 (the approval requirement).

[474]. Id. at 607.

[475]. Id. at 645.

[476]. This is illustrated by the conduct of the committees in Siliconix and Aquila. See Siliconix, 2001 WL 716787, at *5;Aquila, 805 A.2d at 191.

[477]. See17 C.F.R. § 240.14d-101 (2007).

[478]. Pure, 808 A.2d at 445;Cox, 879 at 607 and 645.

[479]. Pure, 808 A.2d at 446;Cox, 879 at 607 and 645.

[480]. Solomon, 672 A.2d at 39.

[481]. For discussion of Cox's emphasis on reducing litigation in freezeouts and unifying freezeout doctrine, see infra Part IV, B and D.

[482]. Pure, 808 A.2d at 445 ("The potential for coercion and unfairness posed by controlling stockholders who seek to acquire the balance of the company's shares by acquisition requires some equitable reinforcement, in order to give proper effect to the concerns undergirding Lynch.”).

[483]. Cox, 879 A.2d at 646 ("The jarring doctrinal inconsistency between the equitable principles of fiduciary duty that apply to Lynch and Siliconix deals has been noted by this court before in Pure Resources and Cysive.”).

[484]. Id. ("It was thought preferable in Pure Resources to keep the strands of the doctrine separate until there is an alteration of Lynch, lest the less than confidence inspiring pattern of "Lynch litigation" replicate itself across-theboard in all going private transactions, thereby deterring the procession of offers that provide valuable liquidity to minority stockholders and efficiency for the economy in general.”).

[485]. In re Cysive, Inc. S'holders Litig., 836 A.2d 531 (Del. Ch. 2003).

[486]. Cox, 879 A.2d 604.

[487]. Cysive, 836 A.2d at 534.

[488]. Id. at 535 .

[489]. It had intended to switch from being fundamentally a services provider to a technology product developer, but

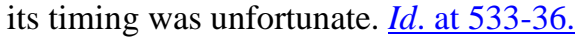

[490]. Id. at 538 .

[491]. Id. at 533-34.

[492]. Id. at 540. 
[494]. Id. at 542. Because of the company's problems, the stock price plummeted. As stated therein: "When the market's infatuation with technology stocks ended, Cysive's formerly lofty stock price dropped precipitously. From its NASDAQ trading high of $\$ 63$ per share in March 2000, Cysive's stock price dropped drastically, eventually reaching a low of $\$ 1.93$ per share in August 2001.” Id. at 536-37.

[495]. Id. at 557.

[496]. Id. at 546-47.

[497]. Id. at 546.

[498]. Id. at 547.

[499]. Id. at 551-52 ("Carbonell holds a large enough block of stock to be the dominant force in any contested Cysive election.”). For another example of a case in which it was questionable whether a shareholder was a controller, see In re Western Nat'l Corp. S'holders Litig., No. 15927, 2000 WL 710192 (Del. Ch. May 22, 2000) (finding, under the Lynch doctrine, that a $46 \%$ shareholder was not a controller based on the factual circumstances).

[500]. See, e.g., Ivanhoe Partners v. Newmont Mining Corp., 535 A.2d 1334 (Del. 1987).

[501]. Cysive, 836 A.2d at 552-53. As defined in the introduction, Carbonell was a de facto controller. For this reason, as the court in Cysive recognized, the sale of the company represented a change of control and implicated Revlon duties. See id. at 557 n.40 ("Whether Revlon duties pertain in a cash deal involving a controlling stockholder is an interesting question the answer to which has little practical effect. Because entire fairness is the most exacting form of review, and because the Snowbird Agreement passes muster under that test, it is difficult to see how the intermediate Revlon standard could be violated.”). Nevertheless, if the Cox Reforms allow Dual Ratification to trigger deferential review, at least where there is a de facto controller, the freezeout will involve a change of controlhence Revlon duties would apply and the target directors would be required to take action consistent with obtaining the best price available for the shareholders. Hence, the Cox Reforms, and the commentary that endorses business judgment deference upon Dual Ratification, have failed to grapple with the relevance of Revlon duties in freezeouts by de facto controllers. See Cox, 879 A.2d at 606; Allen, Jacobs, \& Strine, supra note 17, at 1317; Gilson \& Gordon, supra note 5 , at 786, 838-39.

[502]. Cysive, 836 A.2d at 549 ("These realities suggest that the Lynch doctrine if it is to be perpetuated could be usefully simplified.”).

[503]. Id. at 549-50.

[504]. Id. at 550. The court further contends that even the determination over whether a controller is present has consumed "disproportionate energy" and generally cannot be resolved on the pleadings. $\underline{I d}$. at 550-51.

[505]. Id. at 547.

[506]. Id. at 547-49.

[507]. Id. at 549 .

[508]. See, e.g., Edward B. Rock, Saints and Sinners: How Does Delaware Corporate Law Work?, 44 UCLA L. 
REV. 1009 (1997) (arguing that Delaware fiduciary law operates through normatively saturated, factually intensive narratives that provide guidance to corporate actors about proper and improper conduct in complex transactions).

[509]. Allen, Jacobs \& Strine, supra note 17, at 1292 ("Moreover, new standards of review proliferated when a smaller number of functionally-thought-out standards would have provided a more coherent analytical framework.”).

[510]. Id. at 1317 ("In contrast to current practice, however, we would apply the business judgment review standard to self-interested mergers, in cases where the merger: (1) was expressly conditioned on an informed and uncoerced majority of the minority vote; or (ii) was approved as fair by an effective and uncoerced special committee of independent directors."); id. ("We would also rid the corporate law of the 'waste' exception to the ratification effect currently accorded to informed, uncoerced stockholder votes."); id. at 1321 ("These modest incremental changes should better position the Delaware corporation law to tackle the new doctrinal challenges that will undoubtedly emerge during this new century.”) (emphasis added).

[511]. See, e.g., E. Norman Veasey \& Christine T. Di Gugliemo, What Happened in Delaware Corporate Law and Governance from 1992-2004?, A Retrospective on Some Key Developments, 153 U. PA. L. REV. 1399, 1486 (2005) ( "Having two applicable standards of review available, rather than applying entire fairness review to all transactions involving controlling stockholders, leaves room for the fact-specific, contextual inquiries at which the Delaware courts are adept.”).

[512]. See supra note 126. For further analysis and citation to the case law under section DEL. CODE tit. 8, § 144, see Cox, 879 A.2d at 614-15.

[513]. See, e.g., Cox, 879 A.2d at 609 (“... any amended complaint the plaintiffs might file against an ultimate merger agreement could not be dismissed, per the teachings of Kahn v. Lynch Communication Systems, Inc., if the plaintiffs could plausibly allege unfairness.”).

[514]. Id.

[515]. Cysive, 836 A.2d at 547-48.

[516]. See id. at 549.

[517]. See infra Part IV, C, 2.

[518]. Cysive, 836 A.2d at 547. The court suggests that controllers are so intent on avoiding the costly, duplicative presentation of evidence as part of the proceedings that they prefer to endure full trials in situations where the allocation of the burdens of proof and the relevant standard of review are not resolved prior to trial-that is, in a state of nearly intolerable uncertainty. $\underline{I d}$. at 549.

[519]. Id. at 547 ("Although the trial in this matter has already been held, a major aspect of the parties' post-trial briefs focuses on the standard of review I am to apply to decide the case.”).

[520]. $\underline{I d}$. at 534 ("Because the pendency of this suit was hampering Carbonell's financing efforts, the defendants sought an expedited trial. That request was granted...”).

[521]. Id. at 547-49.

[522]. Id. at 534. 
[523]. Id. at 549 ("Thus, because of the factually intensive nature of the burden-shifting inquiry and the modest benefit obtained by the defendants from the shift, it is unsurprising that few defendants have sought a pre-trial hearing to determine who bears the burden of persuasion on fairness.").

[524]. Id. at 548.

[525]. Id. at 549-50.

[526]. Id. at 549 ("These realities suggest that the Lynch doctrine, if it is to be perpetuated, could be usefully simplified. When the Lynch doctrine governs, it would be simpler to take one of two approaches. If it is thought that giving the plaintiff the opportunity to litigate a case under a favorable fairness standard is sufficient... then the burden of proving unfairness could be placed on, and remain with, the plaintiff from the beginning.").

[527]. Id. at 550.

[528]. Id. at 548.

[529]. Id.

[530]. For a discussion of "framing effects," see Amos Tversky \& Daniel Kahneman, The Framing of Decisions and the Psychology of Choice, 211 SCI. 453 (1981) (explaining framing effects and their significance to rational choice theory).

[531]. See, e.g., Tamar Frankel, Presumptions and Burdens of Proof as Tools for Legal Stability and Change, 17 HARV. J. L. \& PUB. POL'Y 759, 765 (1994) ("If plaintiff-shareholders fail to prove that the board's decision was flawed by lack of care or tainted with conflicts of interest, their actions will be unsuccessful. If plaintiffs prove either flaw, the burden of proof then shifts to the defendants. At this point the gate opens up, allowing judicial scrutiny of the merits of the decision.”).

\section{[532]. Id.}

[533]. For a discussion in the academic literature, see, e.g., STEPHEN M. BAINBRIDGE, MERGERS AND ACQUISITIONS 211 (2003) (“As is often the case, the party bearing the burden of proof on a given dispute lost."); Frankel, supra note 531.

[534]. For the court's treatment of the burden of proof issue in a tender offer freezeout, see Emerging Commc'ns, 2004 Del. Ch. LEXIS 70, at *111 ("Both sides agree that because the Privatization is a self-dealing transaction of which the majority stockholder stands on both sides, entire fairness is the standard of review $a b$ initio. The only question is whether the burden of proof, which normally falls on the defendants, has shifted to the plaintiffs in this particular case." (citations omitted)).

[535]. See, e.g., Cox, 879 A.2d at 618 ("Initially it cannot be ignored that Lynch created a strong incentive for the use of special negotiating committees in addressing mergers with controlling stockholders. This is a very useful incentive.”).

[536]. For a recent application of the principle that informed ratification by disinterested directors or stockholders shifts the burden of proof to plaintiffs and makes the business judgment rule applicable, see, e.g., Orman v. Cullman, No. Civ. A. 18039, 2004 WL 2348395 (Del. Ch. Oct. 20, 2004) (finding that stockholder ratification of the merger, notwithstanding the presence of conflicted directors, shifts the burden to plaintiffs, resolving claims in controller's favor). In Orman, because the court did not interpret the sale as a freezeout, it allowed the business judgment rule to 
apply.

[537]. See, e.g., Cahall v. Lofland, 114 A. 224 (Del. Ch. 1921), aff'd, 118 A. 224 (Del. 1922) (discerning circumstances in which courts should give effect to a burden shift); Fleigler v. Lawrence, 361 A.2d 218 (Del. 1976).

[538]. See, e.g., Gottlieb v. Heyden Chem. Corp., 91 A.2d 57 (Del. 1952). There is no basis to believe that the allocation of the burden of proof is of less importance in self-dealing transactions involving controllers, as opposed to other cases involving self-dealing by corporate fiduciaries.

[539]. For data indicating prevalent employment of special committees in cash-out mergers, see Subramanian, Theory \& Evidence, supra note 23, at 18-19.

[540]. See supra notes, 70-72.

[541]. Veasey \& DiGugliemo, supra note 511, at 1435.

[542]. See, e.g., Cox, 879 A.2d at 606 (arguing that the directors' and minorities' consents are properly understood as complements, not substitutes).

[543]. To bolster its argument that the disinterested, informed nature of the consent of the directors (as a condition to burden shifting) is too complex to be resolved absent a full trial, Cysive cites to the Delaware Supreme Court's nearly contemporaneous decision in Krasner v. Moffett, 826 A.2d 277 (Del. 2003) as authority. Cysive, 836 A.2d at 549. However, there were matters of first impression at issue in Krasner. One was the effect to be given to special committee approval of a merger where a majority of the board had material conflicts of interest in the outcome, because a committee cannot give valid consent to a merger in Delaware. Krasner, 826 A.2d at 286. Krasner does not support a broad reading that the supreme court has determined that the allocation of the burden of proof is too complex to be determined on the pleadings, i.e. without or prior to a trial. In Krasner, furthermore, the Delaware Supreme Court affirmed that defendants have a high burden to win dismissal of a conflicted transaction. As stated therein, it is the defendants "not the plaintiffs [who] bear the burden of proving that the [challenged, interested] merger was approved by a committee of disinterested directors, acting independently, with real bargaining power to negotiate the terms of the merger.” Id. at 284-85. Thus Krasner provides another example of a court allocating importance to the burden of proof in a situation involving a controller, and construing ambiguity in favor of the minority shareholder plaintiffs. On this point, see Kahn v. Tremont Corp., Civ. A. No. 12339, 1992 WL 205637, at *3 (Del. Ch. Aug. 21, 1992), rev'd on other grounds, 694 A.2d 422 (Del. 1997) (finding that the independence of the committee is a question of fact that must turn on the particular realities of the situation). But see Veasey \& DiGuglielmo, supra note 511, at 1471 (suggesting that process determination regarding efficacy of special committees in conflicted transactions is a challenge to legitimate dismissals on the pleadings).

[544]. See SEC Rule 13e-3, 17 C.F.R. § 240.13e-3 (2007). There are many self dealing cases where the Entire Fairness standard applied where the court resolves issues pertaining to the adequacy of disclosures (as they are relevant to the efficacy of minority shareholders' approvals) on motions to dismiss. See, e.g., Orman v. Cullman, No. Civ. A. 18039, 2004 WL 2348395 (Del. Ch. Oct. 20, 2004). Furthermore, if the court was not satisfied that the complaint and the disclosures appended thereto were sufficient, it could order limited discovery and then hear the defendant's motion to dismiss. The point is, the court can control litigation agency costs.

[545]. This is evident from perusing these SEC filings, but also from the judicial analysis of controllers' disclosure in the freezeout cases. See, e.g., Pure, 808 A.2d at 447-52.

[546]. Cysive, 836 A.2d at 536, 542.

[547]. The committee's composition and hiring of its financial advisor are described in Cysive, 836 A.2d at 541-42. 
[548]. Id. at 546 ("After the Snowbird Agreement was signed, the special committee continued to entertain inquiries from interested buyers and to seek diligently a higher price.”).

[549]. Id. at 545 and 546.

[550]. Id. at 543 .

[551]. See SEC Rule 13e-3, 17 C.F.R. § 240.13e-3 (2007); Schedule 13e-3, 17 C.F.R. § 240.13e-100 (2007).

[552]. See NYSE, INC., LISTED COMPANY MANUAL § 303A.02 (defining "independent director" for NYSE listing purposes), available at http:// www.nyse.com/lcm/lcm-section.html; NASD MANUAL, Marketplace Rule 4200(a)(15) (defining "independent director" for NASDAQ listing purposes), available at http://nasd.complinet.com/nasd/display/index.html.

[553]. Cysive is nearly a textbook example of when the courts should allow the controller business judgment deference in litigation.

[554]. The article by Allen, Jacobs and Strine comes to mind. If one accepts that the role of law is to increase economic efficiency defined as growth overall (a contestable assumption), and if one accepts that shareholder litigation inhibits some number of profitable transactions (also contestable- depending on the definition of "profitable"), then the function of Delaware doctrine is to err on the side of facilitating more deals-hence looser standards are preferable. This is the working analytical framework of that law review article, and its relevance to Cysive and Cox (opinions written by one of the article's co-authors) is obvious. See Allen, Jacobs \& Strine, supra note 17, at 1287-88 (describing corporate law's role in relation to economic efficiency).

[555]. See, e.g., Paramount Commc'ns, Inc. v. QVC Network, Inc., 637 A.2d 34 (Del. 1994); Mills Acquisition Co. v. MacMillan, Inc., 559 A.2d 1261 (Del. 1989). For further discussion of the heightened fiduciary standards that apply in other acquisition transactions, see infra Part V, D.

[556]. See, e.g., Malpiede v. Townson, 780 A.2d 1075 (Del. 2001) (affirming Delaware Court of Chancery's granting of motion to dismiss where plaintiffs alleged breach of due care, loyalty, and disclosure); Harbor Fin. Partners v. Huizenga, 751 A.2d 879 (Del. Ch. 1999) (affirming application of business judgment rule and dismissal of disclosure claims in a shareholder challenge to a merger involving conflicted directors); Freedman v. Restaurant Assocs. Indus., Inc., No. Civ. A. 9212, 1990 WL 135923 (Del Ch. Sept. 21, 1990) (granting in part and denying in part defendants' motion to dismiss as part of complex management lead buyout). For a notable summary judgment decision (in favor of defendants) resolving issues relating to the definition of who is a controller, disclosure claims, and the potential presence of deal-stopping lock-ups, see Orman v. Cullman, No. Civ. A. 18039, 2004 WL 2348395 (Del. Ch. Oct. 20, 2004).

[557]. One would think that at this point in the evolution of the transactional choreography for freezeouts and other M\&A transactions that most buyers, and especially controllers, would avoid patent overreaching, however this does not seem to be the true. For a case demonstrating remarkable facts in this regard, see Emerging Commc'ns, 2004 Del. Ch. LEXIS 70, at*119-33 (individual director defendants on special committee were conflicted and exhibited shockingly bad judgment in representing minorities' interests, so that certain of them were found individually to have breached their fiduciary duties).

[558]. Cox's changes to tender offer freezeout doctrine were analyzed in Part III, supra. In many respects, the Cox decision deepens and expands on the Cysive's criticisms of the effects of applying Entire Fairness standard to Freezeouts under the Lynch Doctrine. 
[559]. Cox, 879 A.2d at 607 ("At various times, the Family has found it convenient to take Cox public, in order to raise money from the public capital markets. At other times, the Family has found it preferable to run Cox as a private company.”).

[560]. Id.

[561]. Id. at 605.

[562]. Id.

[563]. Id.

[564]. Id. at 608. The family was quoted as saying that "it would not sell its Cox shares or support a sale of Cox to a third party." Id.

[565]. Id. at 609.

[566]. Id. at 612 .

[567]. Id. at 612-13 ("The Stipulation of Settlement was presented to the Court on November 10, 2004. Notice was promptly issued to the public stockholders on November 24, 2004. By that time, the Family had already commenced their tender offer at $\$ 34.75$ per share.... On December 2, 2004 the tender offer expired ... giving the family over $90 \%$ of the Cox shares. On December 8, 2004 a back end, short-form merger was executed taking Cox private.”).

[568]. Id.

[569]. This issue was resolved in the earlier Stipulation of Settlement presented to the Delaware Court of Chancery on November 10, 2004. See id. at 612-13.

[570]. Id. at 605.

[571]. Id.

[572]. For example, describing the firm that obtained lead counsel status, the Cox court states, "that firm is no ingénue to the lead counsel sweepstakes." Id. at 608. The court describes the plaintiffs' lawyers as engaging in a "food fight" over who would be lead counsel. Id. at 609.

[573]. Id. at 620 (“... plaintiffs sue as soon as there is a public announcement of the controller's intention to propose a merger.... In this regard, this case is paradigmatic.”).

[574]. The interaction of the special committee representing the minority shareholders in negotiations with the Cox family's lawyers and the lawyers for the minority shareholder plaintiffs is described in Cox, 879 A.2d at 608-13. For a discussion of triangulation as a general problem, see $\underline{i d .}$ at $620-21$.

[575]. Id. at 645 .

[576]. Id. at 605-06 ("For their part, plaintiffs' lawyers can get sizable fees by 'contributing' to the successful work of a special committee and by settling at the same level that the special committee achieved.”)

[577]. Id. at 607 . 
[578]. Id. at 605 (“... each Lynch case has settlement value, not necessarily because of its merits, but because it cannot be dismissed.”).

[579]. There is some confusion with respect to the precise nature of the consent/nondisapproval required, as previously noted, supra at notes 473-80 and accompanying text. Although the court is motivated to unify freezeout doctrine, an interesting disconnect appears. In cash-out mergers, Dual Ratification is proposed as the prerequisite to the business judgment rule. Cox, 879 A.2d at 606, 643-44. Hence, neutrality would not be sufficient, which is consistent with DGCL $\S 251$. In the first statement of the proposal for tender offer freezeouts, the absence of disapproval seems to be sufficient. In a later treatment of this question, however, Cox proposes Dual Ratification for tender offer freezeouts to obtain business judgment deference as well. Cox 879 A.2d at 645 .

[580]. Id. at 643-44 ("Put simply, if a controller proposed a merger, subject from inception to negotiation and approval of the merger by an independent special committee and a Minority Approval Condition, the business judgment rule should presumptively apply.” (emphasis in original)).

\section{[581]. See id. at 606-07, 643, 647.}

[582]. The Cox court affirmatively avoids proposing the repeal of Lynch, as Cysive had delicately suggested. Cysive 836 A.2d at 549. Cox contends that the Delaware Supreme Court has never precluded the application of the business judgment rule upon Dual Ratification. See Cox, 879 A.2d at 617. Furthermore, Cox deemphasizes the radicalness of its proposal to apply the business judgment rule to freezeouts upon Dual Ratification as merely "a relatively modest alteration of Lynch.” Id. at 643. In this way the court of chancery is endeavoring to avoid a direct conflict with respected supreme court precedent.

[583]. Cox, 879 A.2d at 620. ("[P]laintiffs sue as soon as there is a public announcement of the controller's intention to propose a merger.").

[584]. Id. at 628 ("When a controller has already had to complete negotiations with a special committee or launched a tender offer, it cannot provide more consideration without implicitly criticizing the special committee (or itself) and without incurring more out of pocket acquisition costs.”).

[585]. Id. at 627. Interestingly, in Cox's lexicon there are only "premature" claims and "tardy" claims. The former are filed against cash-out mergers which are still advertised as negotiable, so that the receipt of a fee by plaintiffs' lawyers is presumed. The latter "tardy" claims are filed against cash-out mergers after terms have been agreed to by controllers and committees-controllers generally refuse to settle those claims according to Cox. See id. at 627.

[586]. Id. at 628.

[587]. Id. at 605 ("Because [the Lynch] standard makes it impossible for a controlling stockholder ever to structure a transaction in a manner that will enable it to obtain a dismissal of a complaint in a challenged transaction, each Lynch case has settlement value, not necessarily because of its merits but because it cannot be dismissed.”).

[588]. See id. at 607, 646.

[589]. 516 U.S. 367 (1996).

[590]. In general, the opinion proposes that controllers settle in order to avoid having to pay the inevitable costs associated with discovery because, the court claims suits under Lynch cannot ever be dismissed, and to avoid the waste of executive time. See, e.g., Cox, 879 A.2d at 606. 
[591]. See, e.g., id. at 619 ("The incentive system that Lynch created for plaintiffs' lawyers is its most problematic feature.").

[592]. Id. at 646.

[593]. Id.

[594]. This is a hallmark of Vice Chancellor Strine's decisions, about which he is not shy. To his credit, his opinions are extraordinarily comprehensive he allows no sacred cows in corporate governance; and does not hide his agenda. For commentary on Vice Chancellor Strine's style of deciding cases, see Gapper, supra note 31.

[595]. See, e.g., In reCaremark Int'l Inc. Derivative Litig., 698 A.2d 959 (Del. Ch. 1996).

[596]. See Cox, 879 A.2d at 605. Cox's assertion of nondismissability is an updated version of the Cysive court's entanglement critique of Lynch. That is, the view that the doctrine is simply so dysfunctional in its complexity that it precludes meaningful determinations without prolonged litigation. Thus, this Article's objections to the Cysive's "entanglement" critique are relevant here as well. See supra notes 503-22 and accompanying text.

[597]. For example, the opinion states that "unlike any other transaction one can imagine ... it [is] impossible after Lynch to structure a merger with a controlling shareholder in a way that permitted the defendants to obtain a dismissal of the case on the pleadings." $\underline{C o x}, 879$ A.2d at 619.

[598]. Id. at 605 .

[599]. Id. at 617. What appears to be an equally undeniable reality is that the Delaware Court of Chancery is frustrated by the substantial demands imposed on the court valuation-based litigation under the Lynch Doctrine and other types of corporate fiduciary cases. But the burdens imposed on courts by valuation litigation would not radically be reduced if the Cox Reforms are adopted because, for example, the Delaware Court of Chancery also hears appraisal actions. Furthermore, valuation analyses are also relevant in claims of breach of fiduciary duty against directors in going private transactions. Getting rid of Entire Fairness in freezeouts is not a solution to the court's methodological problems with valuation therefore.

[600]. Id. at 620 .

[601]. Id. at 620-22.

[602]. Id. at 605.

[603]. Id.

[604]. See id. at 606. See also id. at 643 ("The judicial process should be invoked when a party has a genuine claim of injury. Particularly in the representative litigation context, where there are deep concerns about the agency costs imposed by plaintiffs' attorneys, our judiciary must be vigilant to make sure that the incentives we create promote integrity and that we do not, by judicial doctrine, generate the need for defendants to settle simply because they have no viable alternative, even when they have done nothing wrong.").

[605]. Id. at 606 ("Moreover, I cannot give credence to the notion that the litigation had a substantially important impact on the pricing of the transaction because the plaintiffs' claims were not meritorious when filed and it is most probable that the defendants settled simply because they had, under Lynch, no other economically efficient option for disposal of the lawsuit.”). 
[606]. The Cox court attributes virtually all the increases obtained by special committees in negotiations with controllers to their savvy and organizational stature (in comparison to disaggregated minority shareholders), with only the slightest advantage being conferred by the added leverage of claims filed by plaintiffs under the Entire Fairness standard. As a basis for the conclusion that committees are the driving engines of minorities' receipt of meaningfully high premiums, the Cox court cites the absence of a situation in which "the controller's lawyer told the plaintiffs' lawyer this is my best and final offer and received the answer, 'sign up your deal with the special committee, and we'll meet you in the Chancellor's office for the scheduling conference on our motion to expedite."' Id. at 621. The Cox court proposes that "in every instance, the plaintiffs' lawyers have concluded that the price obtained by the special committee was sufficiently attractive, that the acceptance of the settlement at that price was warranted.” Id.

[607]. Id. at 622, 633.

[608]. Id. at 645.

[609]. Id. at 646.

[610]. See supra Part IV, A.2.

[611]. See id.

[612]. Cox, 879 A.2d at 620.

[613]. Id. at 617 ("Although it is an undeniable reality that Lynch stated that any merger with controlling stockholder, however, structured, was subject to a fairness review...”).

[614]. Weinberger, 457 A.2d at 715 (citing Stauffer v. Standard Brands, Inc., 187 A.2d 78 (Del. 1962) and David J. Greene \& Co. v. Schenley Indus., Inc., 281 A.2d 30 (Del. Ch. 1971)). The Weinberger court continued to explain that "... the provisions of 8 Del. C. \& 262, as herein construed, respecting the scope of an appraisal and the means for perfecting the same, shall govern the financial remedy available to minority shareholders in a cash-out merger." Id. (emphasis added).

[615]. 498 A.2d 1099, 1107-08 (Del. 1985) (finding that plaintiffs had made out a credible claim that the controller had manipulated the timing of the freezeout in a way that constituted unfair dealing-a cognizable issue under the entire fairness standard-rather than merely disputing the price of the cash-out merger, so that the claim should not have been dismissed).

[616]. Weinberger, 457 A.2d at 714-15.

[617]. Rabkin, 498 A.2d at 1107.

[618]. Id. at 1104-05 (“Weinberger's mandate of fair dealing does not turn solely on issues of deception.”); $\underline{i d}$. at $\underline{1105}$ ("In Weinberger we observed that the timing, structure, negotiation and disclosure of a cash-out merger all had a bearing on the issue of procedural fairness.”). In Rabkin, the supreme court reversed the chancery court's conclusion that fair dealing was limited to allegations of misrepresentation. See Rabkin, 480 A.2d 655, 660 (Del. Ch. 1984), rev'd, 498 A.2d 1099, 1104-05 (Del. 1985).

[619]. Rabkin, 498 A.2d at 1107. 
[620]. Id. at 1107-08.

[621]. Id. at 1107.

[622]. Cox, 879 A.2d at 605-06 ("For their part, plaintiffs' lawyers can get sizable fees by 'contributing' to the successful work of a special committee and by settling at the same level that the special committee achieved.”).

[623]. In fairness, Cox does make brief mention of the fact that controllers may enjoy a benefit as the result of a "broad release" of claims relating to the freezeout, but without fleshing out the significance of the reference. See id. at 631 .

[624]. Matsushita Elec. Indus. Co., Ltd. v. Epstein, 516 U.S. 367 (1996).

[625]. Id. at 387. For commentary, see Richard W. Painter, Responding to a False Alarm: Federal Preemption of State Securities Fraud Causes of Action, 84 CORNELL L. REV. 1, 95-98 (1998).

[626]. See Securities Exchange Act of 1934, ch. 404, § 27, 48 Stat. 881, 902 (codified as amended in 15 U.S.C. § 78aa (2000)).

[627]. See15 U.S.C. § 78n (2000 \& Supp. IV 2004); 17 C.F.R. § 240.14a-9 (2007).

[628]. See15 U.S.C. \& 78n(e) (2000 \& Supp. IV 2004) (prohibiting fraud, deceit, and material misrepresentation or omissions "in connection with any tender offer or request or invitation for tenders").

[629]. See Matsushita, 516 U.S. at 369;see also William T. Allen, Finality of Judgments in Class Actions: A Comment on Epstein v. MCA, Inc., 73 N.Y.U. L. REV. 1149 (1998).

[630]. Painter, supra note 625, at 95.

[631]. State fiduciary claims may be heard in federal court as part of federal securities law actions by way of supplemental jurisdiction. See 28 U.S.C. § 1441(c) (2000 \& Supp. IV 2004).

[632]. Thompson \& Thomas II, supra note 51, at 189-94.

[633]. The plaintiffs would have the burden of proof in the federal securities law claims as well, but the presence of ratification in state case law, as suggested by Weinberger, is "strong evidence" of fairness. Weinberger, 457 A.2d at 709 n.7. For further discussion of incentives that favor settling in state court, see Thompson and Thomas II, supra note 51, at 191.

[634]. For the relevance of charter exculpation clauses to claims of fiduciary breach against individual director defendants in freezeouts, see, e.g., Emerging Commc'ns, 2004 Del. Ch. LEXIS 70, at *138.

[635]. These arise by contract but are provided for by Delaware statutory law. SeeDEL. CODE tit. 8, § 145(a) (2007).

[636]. By the express terms of the statute, Delaware charter exculpatory clauses are relevant only to breach of fiduciary duty claims. DEL. CODE tit. 8, \& 102(b)(7) (2007). As a general matter, the federal courts support the SEC's position that corporations may not indemnify their executives against liability for securities fraud. See, e.g., Globus v. Law Research Service, Inc., 418 F.2d 1276 (2d Cir. 1969), cert. denied, 397 U.S. 913 (1970). 
[637]. See supra notes 596-601 and accompanying text.

[638]. Revlon, Inc. v. MacAndrews \& Forbes Holdings, Inc., 506 A.2d 173 (Del. 1986).

[639]. Cox, 879 A.2d at 619.

[640]. Id.

[641]. This is clearly the suggestion made by the objectors to the fee in Cox. Id. at 605. See also Elliott J. Weiss and Lawrence J. White, File Early, Then Free Ride: How Delaware Law (Mis)shapes Shareholder Class Actions, 57 VAND. L. REV. 1797, 1820 (2004). Professor Weiss was among the objectors to the fee in Cox. Cox, 879 A.2d at $\underline{604 .}$

[642]. Revlon, 506 A.2d at 182.

[643]. Revlon, 506 A.2d at 182 (holding that board could not play favorites among bidders once company had been put up for sale and directors' choice of bid that presented certain liability immunizing benefits for themselves was unlawful).

[644]. See, e.g., Paramount Communications, Inc. v. QVC Network, Inc. 637 A.2d 34, 46 n.17 (Del. 1994); Mills Acquisition Co. v. MacMillan, 559 A.2d 1261, 1287-88 (Del. 1989); City Capital Assocs. Ltd. Partnership v. Interco, Inc. 551 A.2d 787, 802 (Del. Ch. 1988), appeal dismissed, 556 A.2d 1070 (Del. 1988) (holding that a disinterested board maintains the right and continues to have the duty to exercise its business judgment in seeking to maximize shareholder value).

[645]. This is reflected, for example, in the fact that duty of care breaches may be exculpated but breach of loyalty claims or other claims involving bad faith or express wrongdoing by fiduciaries cannot be. DEL. CODE tit. 8, § 102(b)(7) (2007).

[646]. See, e.g., Barkan v. Amsted Indus., Inc., 567 A.2d 1279, 1288 (Del. 1989) (where sale of control is implicated, a deal that does not involve a realistic market check may be difficult to sustain).

[647]. See, e.g., In re The MONY Group Inc. S'holder Litig., 852 A.2d 9 (Del. Ch. 2004) (directors did not breach duty, having put the company up for sale, and entered into a merger agreement, which nevertheless allowed for a post signing market check-notwithstanding that they had eschewed an auction).

[648]. The most famous exception in the acquisitions area is Smith v. Van Gorkom, 488 A.2d 858 (Del. 1985). As relevant to freezeouts, however, see Justice Jacobs decision in In re Emerging Commc'ns, Inc. S'holders Litig., No. Civ. A. 16415, 2004 WL 1305745 (Del. Ch. May 3, 2004). Nevertheless, the independent directors in that transaction used extraordinarily bad judgment.

[649]. This is the core complaint presented by Professors Weiss and White in their Vanderbilt Law Review article. See supra note 641.

[650]. Cox, 879 A.2d at 619. The court employs colorful metaphors to ridicule the conduct of the plaintiffs' lawyers in the Cox transaction-for example it describes the process of their selecting lead counsel as resembling a "food fight.” Id. at 609. As an aside, it is difficult to believe that controllers' lawyers are less concerned about their fees and status among their peers than are plaintiffs' lawyers, but their battles over status and fees are less visible.

[651]. See id. at 622. See also id. at 639 ("As the objectors point out, this court has never yielded to plaintiffs and defendants the right to set the level of fees that are awarded in representative actions. Even when defendants agree to 
pay the requested fee fully, the settlement benefits to the class are concededly adequate, and there has been no objection, this court has often reduced the requested fee to a smaller number.”).

[652]. Delaware Chancery Court Rule 23.1(c) provides that "the [derivative] action shall not be dismissed or compromised without the approval of the Court.” DEL. CH. CT. R. 23.1(c).

[653]. Cox, 879 A.2d at 606 ("For reasons I detail, I therefore award a substantially smaller fee than the plaintiffs have requested.”); id. at 642 (awarding fees and expenses totaling $\$ 1.275$ million).

[654]. Id. at 638 (finding that the Chrysler standard governs the payment of fees where plaintiffs' suit has become moot on account of voluntary action by the defendant (citing Chrysler Corp. v. Dann, 223 A.2d 384, 386-87 (Del. 1966)).

[655]. Cox, 879 A.2d at 640 (considering under Sugarland: "1) the benefits achieved in the action; 2) the efforts of counsel and the time spent in connection with the case; 3 ) the contingent nature of the case; 4) the difficulty of the litigation; and 5) the standing and ability of counsel.” (citing Sugarland Industries, Inc. v. Thomas, 420 A.2d 142, 147-50 (Del. 1980)). In Cox, the Delaware Court of Chancery validates the more "traditional" and conservative Sugarland standards as being appropriate for freezeouts. $\underline{\text { Cox, } 879 \text { A.2d at } 640-42}$.

[656]. Cox, 879 A.2d at 605.

[657]. Id. at 606.

[658]. Id.

[659]. Id. at 642.

[660]. Id. at 612 .

[661]. See Hilary Sale, Judges as Gatekeepers in Settlements (forthcoming article, on file with The Business Lawyer). The court's unilateral decision to reduce the agreed fee is more interesting in light of its tremendous emphasis on the legitimacy of outcomes reached through private bargaining.

[662]. Chrysler Corp. v. Dann, 223 A.2d 384, 386-87 (Del. 1966).

[663]. Sugarland Indus., Inc. v. Thomas, 420 A.2d 142, 147-50 (Del. 1980).

[664]. Cox, 879 A.2d at 634-43.

[665]. See Thompson \& Thomas II, supra note 51, at 192-93 (citing data demonstrating that the median attorneys' fee award in federal securities cases from 1991 to 1996 was about 32 percent of the settlement value). In comparison, the median percentage of attorneys' fees in control shareholder acquisition cases was five percent of the additional consideration. Id. at 192. For a discussion of fees computed on an hourly basis, see id. at 193.

[666]. Professors Thompson and Thomas were able to study the figures presented by the plaintiffs' law firms in the briefs they are required to file with the Delaware court of chancery to accompany their fee petitions. As they note, calculating hourly fees on this basis does not take account of the work done by plaintiffs' lawyers in claims that are dismissed without settlement- where no fees are recovered and no figures are extant. Thompson and Thomas II, supra note 51, at 193-94. 
[667]. Id. at 193.

[668]. Id. at 192-93.

[669]. Id. at 192

[670]. See id. at 193.

[671]. Id. at 193 n.222.

[672]. See id. at 200 ("We find that in 20 of 65 of the controlling shareholder cases, additional consideration was paid to the minority shareholders, and in another five cases there were attorneys' fees paid in a settlement.”). The authors note "the contingent nature of these cases." Id. at 193. More particularly, in cases dismissed without settlement (40 out of 65), no fees were paid to plaintiffs' counsel. Id. at 193.

[673]. Cox, 879 A.2d at 605-06.

[674]. See Thompson \& Thomas II, supra note 51, at 199, Table 17; id. at 192 ("If we look at attorneys' fee awards, we see some evidence supporting the claim that Delaware class action litigation has lower litigation agency costs.... In the 20 control shareholder transactions settled in the Delaware courts [in the two year sample studied], the median amount of additional consideration paid to shareholders was about \$15 million. The median percentage of attorney's fees for these cases was 5 percent of the additional consideration (with a range extending up to 37 percent). In dollar terms, the median attorneys' fees awarded by the court were $\$ 875,000$ (with a range extending up to $\$ 4.4$ million).”).

[675]. See Cox, 879 A.2d at 622 ("In seeking fees in these cases, the plaintiffs' lawyers have been pragmatic. Recognizing that they, at best, can claim "shared credit" with the special committee, the plaintiffs' lawyers have tempered their fee requests and have asked for relatively small percentage of the "benefit"-i.e., the difference between the price of the controller's opening bid and the final merger price agreed to by the special committee. But, at the same time, the rewards they reap are substantial....”).

[676]. See Cox, 879 A.2d at 621-23.

[677]. See id. at 625-29.

[678]. See id. at 605-06.

[679]. See id. at 607 ("At the same time, by giving defendants the real option to get rid of cases on the pleadings, the integrity of the representative litigation process would be improved, as those cases that would be filed would involve plaintiffs and plaintiffs' lawyers who knew they could succeed only by filing and actually prosecuting meritorious cases, and not by free riding on a special committee's work.").

[680]. For statements of Cox's Dual Ratification proposal for reforming freezeout doctrine, see id. at 606, 607, 64344, 645, 647.

[681]. Id.

[682]. See supra notes 676-77 and accompanying text.

[683]. See Cox, 879 A.2d at 629 n.57 (“... the relative contributions of the Special Committee and the plaintiffs' counsel have not been, and perhaps cannot be, empirically isolated”); id. at 631 ("One cannot tell, of course, how 
important each of them is as a factor ...”).

[684]. See id. at 647 ("By now, experience has proven that special committees ... are willing to say no to controllers.”).

[685]. See id. at 641-42.

[686]. See id. at 638-40.

[687]. See id. at 621-22 (“... one awkward fact strongly suggests that the threat of bare knuckles litigation over fairness is not as important as the special committee's role as an negotiating force. That awkward fact is the absence of evidence that "traditional" plaintiffs' lawyers, who attacked going private proposals by controllers, have ever refused to settle once they have received the signal that the defendants have put on the table their best and final offer, i.e. an offer that is acceptable to the special committee.”).

[688]. For example, it might be possible to argue that the plaintiffs' lawyers' resolution to follow the lead of special committees in this regard is evidence of the operation of salutary checks and balances in this litigation context, since, after all, the committee has a fiduciary duty to the minority and there is some chance that continued litigation would "kill the deal." It is also possible that the suit added value, by operationalizing the fair duty and fair dealings' promises in the negotiations, but that the plaintiffs' lawyers are giving up too soon because the costs and risks of the lawsuit will radically increase for them once the committee settles. This might suggest that the courts should not routinely approve the settlements but instead encourage the plaintiffs' lawyers to litigate further. It does not provide evidence suggesting that the litigation had no effect to date.

[689]. See Cox, 879 A.2d at 631 ("The plaintiffs' bar would say, of course, this is because they did such a good job in each case that the price concessions they helped the special committee extract was of such inarguable fairness that it would be silly to fight on.”).

[690]. See id. ("Perhaps what can be most charitably said is that the pendency of litigation and the theoretical threat that the plaintiffs will press on provides special committees members with additional clout that they wield to get good results...”).

[691]. See id. at 647.

[692]. DEL. CODE tit. 8, § 251 (2007), amended by 76 Del. Laws ch. 145 §§ 4-7 (2007).

[693]. See supra notes 71-72 and accompanying text.

[694]. See Cox, 879 A.2d at 625.

[695]. See id. at 631 ("Third, litigation under Lynch never seems to involve actual litigation conflict if the lawsuit begins with a suit attacking a negotiable proposal.”).

[696]. Id.

[697]. See id. at 608 ("That complaint was even less meaty than the first filed complaint. It is exemplary of hastilyfiled, first-day complaints that serve no purpose other than for a particular law firm and its client to get into the medal round of the filing speed (also formerly known as the lead counsel selection) Olympics.”).

[698]. See Cox, 879 A.2d at 606, 620 and 622;id. at 622 (“... the plaintiffs' claims always have settlement value 
because of the costs of discovery and time to defendants.”).

[699]. The stay of discovery provisions are codified as amended in 15 U.S.C. §§ 77z-1(b), 78u-4(b)(3) (2000).

[700]. SeeH.R. CONF. REP. NO. 104-369, at 37 (1995), as reprinted in 1995 U.S.C.C.A.N. 730, 736 (calling discovery in securities class actions "fishing expeditions," and noting that some testimony estimated that discovery costs accounted for $80 \%$ of total litigation costs in securities fraud cases).

\section{[701]. Weinberger, 457 A.2d at 709 n.7.}

[702]. Not only the buyer but also the seller in a merger transaction will need to do a due diligence analysis of the inherent value of the company. This was another point illustrated in the sale-through-merger in Smith v. Van Gorkom. In that case the "independent" directors were cowed by the company's chief executive officer; as a consequence they failed to undertake the kind of intensive analysis of their firm that would have furnished an appropriate valuation basis for approving its sale. Smith v. Van Gorkom, 488 A.2d 858, 876-77 (Del. 1985).

\section{[703]. See Cox, 879 A.2d at 618.}

[704]. See id. at 619 (“...history shows that [independent directors] are sometimes timid, inept, or ... well, let's just say worse”).

[705]. See Cox, 879 A.2d at 620 (“... directors involved in the transactions all ... become defendants in lawsuits attacking those transactions”).

[706]. The Lynch doctrine itself only addresses controllers' duties in freezeouts, and not the fiduciary obligations of the target directors themselves. See, e.g., In re Emerging Commc'ns, Inc. S'holders Litig., No. Civ. A. 16415, 2004 WL 1305745 (Del. Ch. May 3, 2004); Van Gorkom, 488 A.2d at 874 (finding that directors breached their duty in approving a sale of the company through a merger by failing to inform themselves of all information reasonably available); McMullin v. Beran, 765 A.2d 910 (Del. 2000) (finding that directors breached their duty to the minority shareholders by turning merger process over to controller, consistent with controller's best interests). In 1995, in the now notorious Technicolor litigation, the Delaware Supreme Court affirmed that the rushed approach of the selling company directors to the approval process, and their failure to conduct a market check of the value of the company prior to approving the deal, constituted a breach of the directors' duty of care. That breach mandated the application of the Entire Fairness standard-the court ultimately concluded that the acquisition of Technicolor met that standard. Cinerama, Inc. v. Technicolor, Inc., 663 A.2d 1156, 1175 (Del. 1995) ("The Court of Chancery properly considered that the Technicolor board's now undisputed lack of care in [failing to make] a market check was a flaw in its approval process.”).

[707]. Directors' fiduciary care liability will often be abridged by charter exculpation, indemnification agreements and insurance. See Bernard Black, Brian Cheffins \& Michael Klausner, Outside Director Liability, 58 STAN. L. REV. 1055 (2006) (distinguishing nominal director liability from actual director liability, noting that directors have virtually never been required to pay damages from personal resources given insurance, indemnification, and exculpation).

[708]. For commentary and citations illustrating the Delaware courts' use of shaming sanctions, see Edward B. Rock, Saints \& Sinners: How Does Delaware Corporate Law Work?, 44 UCLA L. REV. 1009 (1997). The court's "morality tales" also provide instruction for future directors about what is and is not acceptable, consistent with the transactional choreography of freezeouts.

[709]. See, e.g., Cox, 879 A.2d at 647 (proposing that allowing deferential review so long as there is Dual Ratification will "encourage the consistent use of the transaction structure that best protects minority stockholders 
while simultaneously discouraging the filing of premature lawsuits of dubious integrity and social utility”).

[710]. See supra notes 603-21 and accompanying text. The Cox court claims that Rule 11 sanctions are ineffective in this context because "financial fairness is a debatable issue." Cox, 879 A.2d at 620. As discussed supra notes 612-21 and accompanying text, however, financial fairness alone is not a basis to go forward with an Entire Fairness complaint.

[711]. Cox, 879 A.2d at 646. Transactions that appear unfair, even if profitable for one party, may decrease investment and growth over the longer term.

[712]. Id. at 607,643 . The basis of the integrity of a legal system is a complex matter, of course. For further discussion of the social freight carried by the system of shareholder litigation under Delaware corporate law, see James D. Cox, The Social Meaning of Shareholder Suits, 65 BROOK. L. REV. 3 (1999).

[713]. See supra note 680.

[714]. Cox, 879 A.2d at 606, 643.

[715]. Id. at 607.

[716]. Id. at 646; see also id. at 607 (the Cox Reforms would "provide even greater coherence to our law...”).

[717]. For Cox's express appeal to increasing the "integrity" of Delaware corporate law and investors' faith in it via adoption of its proposed reforms, see $\underline{\operatorname{Cox}, 879 \text { A.2d at 606, 607, 613, } 643 .}$.

[718]. Id. at 606 .

[719]. Id. at 644 .

[720]. Again, this is an express objective of the proposed reforms. See, e.g., Cox, 879 A.2d at 607, 643, 644.

[721]. For analysis of Cox's disparagement of the legitimacy and continued relevance of the inherent coercion concept, see infra notes 852-75 and accompanying text.

[722]. See Pure, 808 A.2d at 441.

[723]. See discussion infra at notes 722-76 and accompanying text.

[724]. For “modest,” see Cox, 879 A.2d at 606, 643.

[725]. For the claim that the Cox Reforms would "extend" rather than repeal the Lynch Doctrine, see Cox, 879 A.2d at 606 and 607. See also Pure, 808 A.2d at 444 n. 43.

[726]. For this claim, see Cox, 879 A.2d at 617 ("For this reason, it is important not to assume that the Supreme Court has already rejected this more precisely focused contention.”). The court contradicts this assertion earlier in the opinion however. $\underline{I d}$. at 616 ("Even if the transaction was 1) negotiated and approved by a special committee of independent directors; and 2) subject to approval by a majority of the disinterested shares ..., the best that could be achieved [under Lynch] was a shift of the burden of persuasion on the issue of fairness from the defendants to the plaintiffs.”). 
[727]. In administering these claims, courts could delay the fair price inquiry until after they addressed fair dealings, but the "burden" of the fair dealings inquiry would remain if the Cox Reforms are to be interpreted as anything other than a total abdication of equity's role in freezeouts.

[728]. For this suggestion in the Cox opinion, see 879 A.2d at 644.

[729]. At present these actions are commonly combined. See, e.g., In re Emerging Commc'ns, Inc. S'holders Litig., No. Civ. A. 16415, 2004 WL 1305745 (Del. Ch. May 3, 2004).

[730]. As the data collected by Professors Thompson and Thomas indicate, appraisals are presently used infrequently by aggrieved minorities in cash-out merger, in comparison to class action Entire Fairness suits. See Thompson \& Thomas 11, supra note 51, at 170 ("Appraisal proceedings make up a very small portion of the Chancery Court docket ...”); see also Gilson and Gordon, supra note 5, at 799 (“... the economics of the litigation process mean that, if a fight about price is limited to appraisal, the controlling shareholder is exposed as to price only with respect to the number of shares for which appraisal rights are perfected, typically a quite small number.”). For further statistical information about the incidence of appraisal actions see Thomas, Delaware Appraisal, supra note 184, at 22 (finding fewer than 14 cases per year since 1977 and analyzing ways that appraisal falls short of meeting the needs of investors and the express goals of the statute); compare Wertheimer, supra note 166, at 626 (noting that "the number of reported appraisal decisions has expanded greatly" despite the notable shortcomings in the appraisal statute).

[731]. For discussion of the Pure court's expressed frustration and dissatisfaction with assessing value in freezeouts and its relative preference for a "process based" solution, see Gilson \& Gordon, supra note 5, at 834 ("We are sympathetic to the Pure court's preference for a resolution to the treatment of freeze-outs that focuses on the court's assessing process, rather than determining value.”).

[732]. See supra notes 261-71 and accompanying text. For decades there have been calls to reform the appraisal process. See infra note 733. Those reform proposals have never succeeded-but that lack of success may be attributable to the fact that the equitable cause of action for Entire Fairness under the Lynch Doctrine has remained an attractive option for minority investors to challenge cash-out mergers. If the Cox Reforms are adopted, however, the legal landscape will have changed substantially, and the Delaware Legislature will be under greater pressure to defend minorities' interests in freezeouts through modifications to the appraisal remedy.

[733]. See, e.g., Thomas, Delaware Appraisal, supra note 184, at 1 (“Modern appraisal statutes are a mess.”); Wertheimer, supra note 166; Thompson, Exit, supra note 184.

[734]. See, e.g., Subramanian, Fixing Freezeouts, supra note 5, at 8; Gilson \& Gordon, supra note 5, at 839-40; Letsou \& Haas, supra note 113, at 94.

[735]. Cox, 879 A.2d at 644.

[736]. Id. at 647. It is noteworthy that in adopting this metaphor the court implicitly affirms that shareholder litigation is viewed as a form of warfare. Id.

[737]. Id. at 644.

[738]. This issue of director personal liability in freezeouts relates back to Weinberger. It is striking in that case that while the court expresses horror at the conduct of Signal's directors on UOP's board it never even implies that they might be held personally liable for fiduciary breach. See Weinberger, 457 A.2d at 708 ("A primary issue mandating reversal is the preparation by two UOP directors, Arledge and Chitea, of their feasibility study for the exclusive use and benefit of Signal."). 
[739]. See, e.g., In reWalt Disney Co. Derivative Litig., 907 A.2d 693 (Del. Ch. 2005), aff'd, 906 A.2d 27 (Del. 2006); but see In re Emerging Commc'ns, Inc. S'holders Litig., No. Civ. A. 16415, 2004 WL 1305745 (Del. Ch. May 3, 2004); Lynch v. Vickers Energy Corp., 383 A.2d 278, 282 (Del. 1977) (finding liability against controller and holding individual directors harmless).

[740]. See supra notes 243-49.

[741]. Cf. In re Emerging Commc'ns, Inc. S'holders Litig., No. Civ. A. 16415, 2004 WL 1305745 (Del. Ch. May 3, 2004).

[742]. See supra notes 707.

[743]. Controllers' preference for obtaining directors' consents is noted in Cox, 879 A.2d at 618 (“ $\ldots$ the absence of any additional standard of review-affecting benefit for a Minority [Shareholder] Approval Condition, has made the use of that independent, and functionally distinct, mechanism less prevalent”).

[744]. Cox, 879 A.2d at 618 ("But Lynch also created other unintended and unanticipated effects.... For starters, the absence of any additional standard of review-affecting benefit for a Minority Approval Condition, has made the use of that independent and functionally distinct, mechanism less prevalent.....As a result, Lynch did not tend to make prevalent the transactional structure that most clearly mirrors an arms' length merger.”).

[745]. For further discussion, see supra notes 121-29 and accompanying text.

[746]. In the Emerging Communications litigation the defendants made the novel argument that the majority of the minority's tendering their shares operated as consent to the transaction which waived their right to bring suit for fiduciary breach. Justice Jacobs (sitting by designation) did not have to resolve what legal effect could be given to such a waiver, because he had ruled that the disclosure to the shareholders was deficient. He did observe, however, that no Delaware court has approved that shareholders' sales in tender offers should be considered the equivalent of an affirmative shareholder vote. This admonition aside, there will be considerable pressure on the Delaware Supreme Court to move in this direction. See Emerging Commc'n, 2004 Del. Ch. LEXIS 70. at *110.

[747]. DEL. CODE. ANN. tit. 8, § 144 (2007).

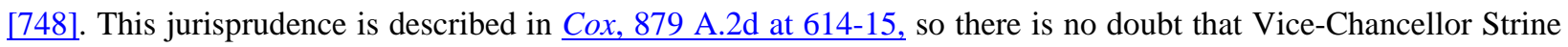
was mindful of the issue.

[749]. 488 A.2d 858 (Del. 1985) (finding shareholder ratification void and hence insufficient to protect the directors from financial liability on account of their demonstrated breach of fiduciary care because the disclosures in the proxy statement were deficient).

[750]. No. Civ. A. 18039, 2004 WL 2348395 (Del. Ch. Oct. 20, 2004) (ruling that the disclosure to the shareholders was acceptable so that their vote triggered the waste standard and nullified the duty of loyalty claims against the board).

[751]. 751 A.2d 879, 900-01 (Del. Ch. 1999).

[752]. See Orman, $2004 \mathrm{WL} 2348395$, at *5 (finding that the fully informed vote of a majority of company's disinterested shareholders would be effective to trigger business judgment rule so that the special committee directors would not be liable in approving the sale of the company). See also, e.g., J. Robert Brown, Jr., Speaking with Complete Candor: Shareholder Ratification and the Elimination of the Duty of Loyalty, 54 HASTINGS L. J. 


\section{[753]. Cox, 879 A.2d at $614-15$.}

[754]. For a decision where the court found that informed, uncoerced minority shareholder ratification precluded a finding of liability against defendant directors, and granted summary judgment on that basis, see Orman, 2004 WL 2348395; see also Harbor Fin. Partners, 751 A.2d at 900-01 (discussing the exculpatory effect of disinterested shareholder ratification on a duty of loyalty claim, outside of a freezeout). There is controversy regarding whether shareholder ratification can expunge a duty of loyalty claim against controllers in a freezeout. Shareholder ratification of directors' fiduciary breaches is frequently invalidated on the basis of shareholders being inadequately informed. See, e.g., Van Gorkom, 488 A.2d at 858 (invalidating shareholder ratification of directors' breach of their duty of care because shareholders were inadequately informed). For a discussion of this issue, see In re JCC Holdings Co., Inc., 843 A.2d 713, 722-23 (Del. Ch. 2003) (holding that the voting of plaintiff minority shareholders in favor of accepting consideration in a merger effectuated by a controlling stockholder does not bar them, on the basis of acquiescence, or any other related doctrine of waiver, from challenging the fairness of the merger in an equitable action).

[755]. Cox, 879 A.2d at 618-19.

[756]. See id. at 646 ("It was thought preferable in Pure Resources to keep the strands [of freezeout doctrine] separate until there is an alteration in Lynch, lest the less than confidence inspiring pattern of 'Lynch litigation' replicate itself across the board in all going private transactions, thereby deterring the procession of offers that provide valuable liquidity to minority stockholders and efficiency for the economy in general.”).

[757]. Lynch and Solomon are less radically far apart in their treatment of fair process in freezeouts. They both prohibit coercion and fraud by controllers. However, while the Lynch Doctrine takes an "affirmative" approach, making controllers accountable for "fair dealings," the Solomon standards merely prohibit misconduct by controllers. But this is essentially a difference in degree or approach. Both doctrines affirm that there are legally enforceable limits on the process through which controllers can effectuate a freezeout.

[758]. See supra notes 214-31 and accompanying text.

[759]. See supra notes 173-82 and accompanying text.

[760]. See Cox, 879 A.2d at 642-48 ("A Coda on the Jurisprudential Elephant in the Corner”).

[761]. See id. at 646. In this respect, the Cox Reforms should not be seen as a middle ground between the two. Rather, the Lynch Doctrine is being folded into Solomon's more lenient framework-with a consequent "yielding” of the fair price duty as it would apply to negotiations.

[762]. See supra notes 173-82 and accompanying text.

[763]. For excellent discussion of the not easily enforceable and sometimes loose limits applicable to controllers' obtaining private benefits from the corporation during its ongoing operations, see Gilson \& Gordon, supra note 5, at 789-93. See alsoSinclair Oil Corp. v. Levien, 280 A.2d 717 (Del. 1971) (applying very different equitable standards to (i) the parent's preferred dividend policy, (ii) the parent's general oversight of the subsidiary's management consistent with its overall interests, (iii) whether the company had taken a particular business opportunity that belonged to the subsidiary and (iv) the enforcement of another wholly owned subsidiary's contract with the first subsidiary). 
[765]. See id. at 721-22.

[766]. As noted by Professors Gilson and Gordon, supra note 5, at 835-36, controlled companies are exempt from the NYSE and NASD listing standards requiring an absolute majority of directors on the board, but must still have a minimum of three independent directors to compose an audit committee that complies with SOX's requirements. See 15 U.S.C. \& 78j-1(m)(3)(B) (2000 \& Supp. IV 2004); Self-Regulatory Organizations; Notice of Filing of Proposed Rule Change and Amendment No. 1 Thereto by the New York Stock Exchange, Inc. Relating to Corporate Governance, 68 Fed. Reg. 19051, 19052 (Apr. 17, 2003). The NYSE proposal and the comparable NASD proposal were approved. Self-Regulatory Organizations; New York Stock Exchange. Inc. and National Association of Securities Dealers, Inc.; Order Approving Proposed Rule Changes and Amendments No. 1 Thereto and Notice of Filing and Order Granting Accelerated Approval of Amendments Relating to Corporate Governance, 68 Fed. Reg. 64154 (Nov. 12, 2003).

[767]. See, e.g., Cox, 879 A.2d at 632 ("Fourth, minority stockholders seem to be doing more than tolerably well under both the Lynch and Siliconix regimes. Even if premiums to market are lower in Siliconix transactions, the premiums paid are large in comparison to the routine day-to-day trading prices in which minority and liquidity discounts will be suffered.”). On the limited significance of the market trading price, and hence a premium to the market price, as an indicia of a company's value see also Van Gorkom, 488 A.2d at 875-76 (concluding where no controller was present that "[u]sing market price as a basis for concluding that the premium adequately reflected the true value of the Company was a clearly faulty, indeed fallacious premise...”); Emerging Commc'n, 2004 WL

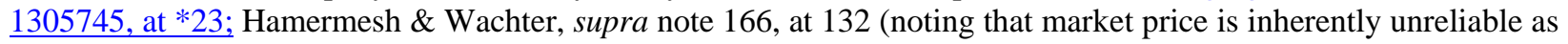
an indicia of the value of minority shares, if they are assumed to represent a pro rata share of the residual value).

[768]. See, e.g., David A. Hoffman, The Best Puffery Article Ever, 91 IOWA L. REV. 1395 (2006); Jennifer O'Hare, The Resurrection of the Dodo: The Unfortunate Re-Emergence of the Puffery Defense in Private Securities Fraud Actions, 59 OHIO ST. L.J. 1697 (1998).

[769]. See, e.g., HERSH SHEFREN, BEYOND GREED AND FEAR: UNDERSTANDING BEHAVIORAL FINANCE AND THE PSYCHOLOGY OF INVESTING 184-89 (2000).

[770]. The law serves an "expressive function," indicating to people what is right and wrong which is distinct from what is legally sanctionable. Richard H. McAdams, A Focal Point Theory of Expressive Law, 86 VA. L. REV. 1649, 1650-51 (2000); Richard H. Pildes \& Cass R. Sunstein, Reinventing the Regulatory State, 62 U. CHI. L. REV. 1, 64$\underline{72(1995)}$.

[771]. In effect this Article's proposals assert that the controller is inhibiting the board from fulfilling its duty of care if it blocks the committee's investigation of alternatives, e.g. prevents it from conducting an auction or market check. See Van Gorkom, 488 A.2d at 872 ("The determination of whether a business judgment is an informed one turns on whether the directors have informed themselves 'prior to making a business decision, of all material information reasonably available to them.”' (citations omitted)).

[772]. In addition, if the Entire Fairness standard and its fair price duty apply to all freezeouts, then as these deals are litigated, there will be a record of the valuation methodologies which are acceptable for the committee to consider in analyzing the merits of a controller's offer, as was the case in Emerging Commc'n, 2004 Del. Ch. LEXIS 70, at *43-101.

[773]. Controllers will surely threaten to pull the offer if the committee does not approve. That many would do so is attested to in the Cox opinion. See Cox, 879 A.2d at 625. Once this happens in enough freezeouts, committees will anticipate being blamed in the media for killing the deal if they disapprove of it. Given the court of chancery's fervently expressed preferences for freezeouts going forward, at least as evidenced in Siliconix, Pure and Cox, it will 
be very hard for committees to risk terminating the transaction by disapproving it.

[774]. Cox, 879 A.2d at 643-44.

[775]. Id. at 607 .

[776]. Id. at 606 .

[777]. See Van Gorkom, 488 A.2d at 873 ("A director may not abdicate his duty by leaving to the shareholder alone the decision to approve or disapprove the agreement [of merger].”); McMullin 765 A.2d at 919 (“... when the proposal to merge with a third party is negotiated by the majority shareholder, the board cannot abdicate that duty [to make an informed judgment on the merger] by leaving it to the shareholders alone to approve or disapprove the merger agreement because the majority shareholder's voting power makes the outcome a preordained conclusion.

[778]. As stated above, controlled companies will need to have a minimum of three directors to conform to the exchanges' listing standards for audit committees. See supra note 766 and accompanying text.

[779]. 826 A.2d 277, 286 (Del. 2003).

[780]. SeeN.Y. BUS. CORP. LAW § 713 (McKinney 2003).

[781]. See Cox at 879 A.2d at 646 (describing its Dual Ratification proposal for freezeouts as a "principled reconciliation of the two lines" of freezeout doctrine, and citing Gilson and Gordon's work as a model solution in this regard).

[782]. See Cox, 879 A.2d at 621-31.

[783]. Id.

[784]. See Thompson \& Thomas II, supra note 51, at 202; Cox, 879 A.2d at 626.

[785]. Subramanian, Theory \& Evidence, supra note 23; see Cox, 879 A.2d at 625-31;id. at 625 ("Subramanian makes two major arguments. First Subramanian cites to his own recent scholarly studies to support his view that the Lynch form of transaction results, on average, in going private transactions that pay the minority a higher premium in comparison to the preannouncement market price than do Siliconix deals. Second, Subramanian attempts to show that the filing of lawsuits under Lynch challenging going private merger proposals by controlling stockholders are a material factor in producing these more favorable results. I will now explain in summary form Subramanian's arguments and explain why I conclude that the first of his arguments is his strongest, and that his other point is less convincing.”).

[786]. See Weiss \& White, supra note 641, at 1804 (“Thus, in most mergers involving conflicts of interest and especially in mergers involving sales of control, the combination of corporate practice and Delaware law appears to have provided plaintiffs' attorneys with substantial incentives to file class actions, regardless of whether it appeared that fiduciary duties had been or would be breached.").

[787]. A significant caveat is required: Notwithstanding his conclusions about the beneficial effects of claims filed under the Entire Fairness standard, Professor Subramanian endorses the kind of "hybrid," dual consent-based solution to unifying freezeout doctrine put forward by the court in Cox-i.e. that Entire Fairness should not apply in cases where a special committee and a majority of the minority approve of the transaction. It would seem then that Professor Subramanian believes that committees will be able to push controllers to pay fair prices through negotiations even if the Entire Fairness standard is substantially relaxed. See Subramanian, Fixing Freezeouts, supra 
note 5 , at 8 .

[788]. See Cox, 879 A.2d at 613 (“... Weiss has recently turned his attention to the class action settlement process in corporate law cases, most particularly in the courts of Delaware. Aside from objecting in two cases himself, Weiss, along with Professor Lawrence J. White, an economist at New York University, has published an article called File Early, then Free Ride: How Delaware Law (Mis)Shapes Shareholder Class Actions that argues that certain features of Delaware's common law of corporations have permitted the plaintiffs' bar to reap windfall profits by filing cases that have no benefit to stockholders.") (emphasis added).

[789]. See, e.g., Cox, 879 A.2d at 646.

[790]. The Cox court cites the objectors' view that "litigation of this kind is of no material benefit to minority stockholders," $i d$. at 624, but it does not present their evidence for that assertion, and thus the evidence never comes under scrutiny.

[791]. Id. at 613.

[792]. The court concludes that the Entire Fairness standard precludes timely dismissals, hence invites nonmeritorious cases which, in turn, are settled by controllers in order to avoid costly discovery and other inefficiencies associated with further litigation. Id. at 631.

[793]. Rabkin, 498 A.2d at 1107.

[794]. See supra notes 94-104 and accompanying text.

[795]. See supra notes 84-85 and accompanying text.

[796]. For the most recent jurisprudence on eminent domain, see Kelo v. City of New London, Conn., 545 U.S. 469 (2005) (affirming local government's power to seize land for financial redevelopment purposes consistent with the Fifth Amendment to the United States Constitution).

[797]. See, e.g., U.S. CONST. amend. V.

[798]. See, e.g., McMullin, 765 A.2d at 920 ("When a majority of a corporation's voting shares are owned by a single entity, there is a significant diminution in the voting power of the minority stockholders. Consequently, minority stockholders must rely for protection on the fiduciary duties owed to them by the board of directors.").

[799]. See infra notes 800-03 and accompanying text.

[800]. SeeDEL. CODE tit. 8, § 141(a) (2007); McMullin, 765 A.2d at 916-17.

[801]. Cox, 879 A.2d at 614.

[802]. DEL. CODE tit. 8, § 142(b) (2007).

[803]. For an economics-oriented description of corporate governance arrangements, see, e.g., Margolin and Kursh, supra note 166, at 414 ("The corporate form, characterized by the introduction of outside equity investors, evolved to transfer the risk of firm operations from high-cost risk bearers (management), to low-cost risk bearers (stockholders), but accomplishes this only at the expense of relaxing hierarchical constraints on managerial malfeasance.”). 
[804]. See, e.g., Cysive, 836 A.2d at 533 ("This post trial opinion addresses stockholder-plaintiffs' challenge to a management buy-out proposed by defendant Nelson Carbonell, the Chairman, Chief Executive Officer, director, and largest stockholder of Cysive, Inc....”).

[805]. In Pure, Unocal was limited by a shareholder agreement to five representatives on Pure's board of eight. Of these, one was Unocal's treasurer; a second was Unocal's President and COO and a director of Unocal; a third was a retired executive who had worked at Unocal for 34 years and still provided consulting services to it; a fourth was "an executive for many years at Unocal before 1992;" a fifth was "a close personal friend of Unocal's President and COO.” The latter director was on Pure's special committee in fact. See Pure, 808 A.2d at 425-26.

[806]. See supra note 766.

[807]. See McMullin, 765 A.2d at 920 (noting board's responsibility in considering a merger to judge whether the "transaction maximized value for all shareholders"); $\underline{i d .}$ at 918 ("The Chemical Board owed fiduciary duties of care, loyalty and good faith to all Chemical shareholders in recommending a sale of the entire corporation.”).

[808]. Id. at 921-22 (describing the basis for overturning the court of chancery's dismissal of the complaint allowing breach of fiduciary duty in a situation where the controller effectively pushed through the sale of the company against the minority's best interests).

[809]. Weinberger, 457 A.2d at 715.

[810]. This conclusion is reflected, for example, in McMullin, 765 A.2d at 920 and Paramount Commc'n, 637 A.2d at 42.

[811]. Pure, 808 A.2d at 429 (In its announcement of the tender offer freezeout, Unocal stated: “... we are not interested in selling our shares in Pure.”); Cox 879 A.2d 607-08 (“...the Family did state that it would not sell its Cox shares or support a sale of Cox to a third party.").

[812]. See, e.g., Pure, 808 A.2d at 446.

[813]. See Cox, 879 A.2d at 607 ("by giving defendants the real option to get rid of cases on the pleadings, the

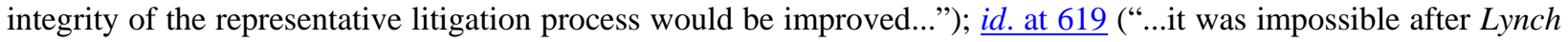
to structure a merger with a controlling stockholder in a way that permitted the defendants to obtain dismissal of the case on the pleadings."); id. at 130 ("As important, this incentive would enable transactional planners to know that they can structure transactions in a way that affords them the opportunity to obtain a dismissal on the complaint.").

[814]. See Solomon, 672 A.2d at 39 ("In the case of totally voluntary tender offers, as here, courts do not impose any right of the shareholders to receive a particular price.”).

[815]. See Pure, 808 A.2d at 444 n.43, 445;Cox, 879 A.2d at 606, 607, 643-44, 646; Cysive, 836 A.2d at 549-50.

[816]. See supra citations in note 5.

[817]. The role of law in supporting strong capital markets is considered in both the Pure and Cox opinions. See Pure, 808 A.2d at 433-44;Cox, 879 A.2d at 646 (the Lynch Doctrine should be reformed because it is inhibiting transactions that provide "efficiency for the economy in general").

[818]. For consideration of the role of economic thought in contemporary corporate law, see, e.g., STEPHEN M. 
BAINBRIDGE, CORPORATION LAW AND ECONOMICS (Foundation Press 2002). For a more progressive analysis, see LYNNE L. DALLAS, LAW AND PUBLIC POLICY: A SOCIOECONOMIC APPROACH (Carolina Academic Press 2005).

\section{[819]. ADOLPHE A. BERLE JR., AND GARDINER C. MEANS, THE MODERN CORPORATION AND} PRIVATE PROPERTY (1932).

[820]. See Jensen \& Meckling, supra note 179.

[821]. Gilson and Gordon, supra note 5.

[822]. See, e.g., Blair \& Stout, supra note 66; Lynn A. Stout, The Shareholder as Ulysses: Some Empirical Evidence on Why Investors in Public Corporations Tolerate Board Governance, 152 U. PA. L. REV. 667 (2003). For discussion of team production's place in the evolution of corporate legal theory see Peter C. Kostant, Team Production Theory and the Progressive Corporate Law Agenda, 35 U.C. DAVIS L. REV. 667 (2002).

[823]. As used in contemporary corporate legal scholarship the term "rent-seeking" refers to the pursuit of above market returns through the exploitation of an advantage nonsusceptible to competition, for example an anticompetitive regulation. For a study analyzing rent-seeking, see Sanjay Gupta and Charles W. Swenson, Rent Seeking by Agents of the Firm, 46 J. LAW \& ECON. 253 (2003) (creating an empirical model to measure rent-seeking by corporate executives and then applying it to firms' political contributions to see if they track managers' interest in tax relief relevant to executive compensation). Admittedly, the board's placing the committee in the role of advocate for the minority, in facing up to the controller, is a slight departure from the basic model, but the team production construct still has relevance, especially with the board in the background and the controller looming.

[824]. See, e.g., DAVID SCIULLI, CORPORATE POWER IN CIVIL SOCIETY: AN APPLICATION IN SOCIETAL CONSTITUTIONALISM (New York University Press 2001).

[825]. See, e.g., Linda C. McClain \& James E. Fleming, Some Questions for Civil Society-Revivalists, 75 CHLKENT L. REV. 301 (2000).

[826]. At first glance, the Cox court's Dual Ratification proposal is consonant with these theoretical frameworks as well; not only does the Cox court affirm the importance of voluntary consent, it requires Dual Ratification unlike the court in Lynch that allows either shareholder or director consent to shift the border of proof. The Cox court proposes that the two forms of consent are complementary to one another; that they provide heightened protections to minority shareholders over Lynch. According to Cox, directors are more effective negotiators, but the Cox court also allows for the possibility that the independent director may be lazy or inept or less than independent and recommends a requirement of minority shareholder ratification, as a check on the directors' diligence and judgment. See Cox, 879 A.2d at 618-19. However, there is a significant difference between employing consent as a burden shifting device and using it as a rationale for limiting judicial review.

[827]. Cox, 879 A.2d at 647 ("By now, experience has proven that special committees and independent board majorities are willing to say no to controllers. Experience has also shown that disinterested stockholders, given a non-coercive choice, will reject low ball tender offers by controllers.”).

[828]. We are only beginning to see empirical studies on freezeouts. In Cox the court was highly critical of the only study that provides some data on committees' acceptances and rejections of controllers' offers, see Subramanian, Theory \& Evidence, supra note 23. There is information about settlement rates in suits filed against freezeouts, but not information relevant to Cox's assertion about committees' disapprovals of unfair offers in Thompson and Thomas II, supra note 51. Weiss and White's study also contains empirical analysis of claims and settlements in freezeouts, but their data does not illuminate whether directors have genuine freedom to disapprove unfair 
freezeouts. Weiss \& White, supra note 641.

[829]. The question was hotly debated in the late 1980s when there were many leveraged buyouts. See, e.g., William T. Allen, Independent Directors in MBO Transactions: Are They Fact or Fantasy?, 45 BUS. LAW. 2055 (1990).

[830]. See supra note 767.

[831]. See, e.g., Cox \& Munsinger, supra note 90. On the subject of the organizational dynamics that influence groups to avoid conflict and side with the popular perspective, see Richard H. McAdams, Cooperation and Conflict: The Economics of Group Status Production and Race Discrimination, 108 HARV. L. REV. 1003 (1995).

[832]. Marleen A. O'Connor, Women Executives in Gladiatorial Corporate Cultures: The Behavioral Dynamics of Gender, Ego and Power, 65 MD. L. REV. 465, 494 (2006); James D. Westphal, Defections from the Inner Circle: Social Exchange, Reciprocity and the Diffusion of Board Independence in U.S. Corporations, 42 ADMIN. SCI. Q. 161, 163-64 (1997); Donald C. Langevoort, The Human Nature of Corporate Boards: Law, Norms, and the Unintended Consequences of Independence and Accountability, 89 GEO. L.J. 797, 811 (2001) ( "For a variety of reasons, the natural gravitational pull is away from diversity towards collegiality.”).

[833]. The "tightly-knit" nature of corporate boards, even after the recent financial accounting scandals, is illustrated by the enormous outpouring of negative comment letters resulting from the SEC's proposed conservative version of a shareholder nomination rule. See Proposed Rule: Security Holder Director Nominations, SEC Rel. No. 34-48626, 68 Fed. Reg. 60784 (Oct. 23, 2003).

[834]. The CEO is unlikely to take a position adverse to the controller and therefore may be unhelpful to the outside directors in terms of what information is shared. See generally Lawrence E. Mitchell, Structural Holes, CEOs, and Informational Monopolies, 70 BROOK. L. REV. 1313 (2005); James D. Westphal, Board Games: How CEOs Adapt to Increases in Structural Board Independence from Management, 43 ADMIN. SCI. Q. 511 (1998); Daniel R. Fischel, The Corporate Governance Movement, 35 VAND. L. REV. 1259, 1282 (1982) (opining that outside directors' limited information about operating details limits their utility in crucial respects).

[835]. See Bernard Black, Brian Cheffins \& Michael Klausner, Outside Director Liability, 58 STAN. L. REV. 1055, 1138-39 (2006).

[836]. For a discussion of the time constraints that may limit outside directors' utility, in relation to executive compensation issues, see, e.g., Michael B. Dorff, Does One Hand Wash the Other? Testing the Managerial Power and Optimal Contracting Theories of Executive Compensation, 30 J. CORP. L. 255, 266 (2005).

[837]. See Jeffrey N. Gordon, What Enron Means for the Management and Control of the Modern Business Corporation: Some Initial Reflections, 69 U. CHI. L. REV. 1233, 1242 (2002) (considering director compensation).

[838]. Report of Investigation by the Special Investigative Committee of the Board of Directors of Enron Corp. 1-17 (Feb. 1, 2002), available at http:// news.findlaw.com/hdocs/docs/enron/sicreport/sicreport020102.pdf; William W. Bratton, Enron and the Dark Side of Shareholder Value, 76 TUL. L. REV. 1275, 1305-15 (2002) (describing extensive self dealing transactions at Enron); Robert Prentice, Enron: A Brief Behavioral Autopsy, 40 AM. BUS. L.J. 417, 428-34 (2003) (explaining how decisional heuristics and cognitive biases can help explain the actions of various actors, including outside directors in the Enron scandal); Arnoud W.A. Boot \& Jonathan R. Macey, Monitoring Corporate Performance: The Role of Objectivity, Proximity, and Adaptability in Corporate Governance, 89 CORNELL L. REV. 356, 368-73 (2004) (noting that boards tend over time to internalize managers' values and therefore lose their objectivity as they become unduly influenced by management's perspective). Special problems arise, of course, in cases in which the controller is the senior executive officer. Note the case of Hollinger International, Inc. where controlling shareholders allegedly looted \$400 million over four years. Hollinger Inc. Says 
SEC May Bring a Civil Lawsuit Against It, N.Y. TIMES, Aug. 31, 2004, at C2.

[839]. See Bratton, supra note 838, at 1332-34; Gordon, supra note 837, at 1241-44.

[840]. For facts relating to WorldCom's board, see, e.g., In re WorldCom, Inc. Sec. Litig., 294 F. Supp. 2d 392 (S.D.N.Y. 2003).

[841]. Emerging Commc'ns, 2004 Del. Ch. LEXIS 70, at *140-47.

[842]. Cox, 879 A.2d at 619, 647. Institutions are more likely to focus on individual firms where there is a buyout offer, but the well-discussed limits to institutional investor activism are still powerful in freezeouts. See, e.g., James D. Cox \& Randall S. Thomas, Letting Billions Slip Through Your Fingers: Empirical Evidence and Legal Implications of the Failure of Financial Institutions to Participate in Securities Class Action Settlements, 58 STAN. L. REV. 411, 425-28 (2005); Edward Rock, The Logic and (Uncertain) Significance of Institutional Shareholder Activism, 79 GEO. L.J. 445, 466-68 (1991). Furthermore, there will also be conflicts between larger and smaller institutional investors in public companies.

[843]. Bernard S. Black, Agents Watching Agents: The Promise of Institutional Investor Voice, 39 U.C.L.A. L. REV. 811, 821-25 (1992) (describing financial conflicts of interest and legal regulations that hinder greater institutional investor activism).

[844]. These rules are discussed in Bernard S. Black, Shareholder Passivity Reexamined, 89 MICH. L. REV. 520 $\underline{(1990)}$.

[845]. For an account of these conflicts, see Adrian Cadbury, \& Ira M. Millstein, The New Agenda for ICGN [International Corporate Governance Network], in 1506 PLI/Corp 673, 698-99, PLI, CORP. LAW AND PRAC. COURSEBOOK HANDBOOK SERIES, Sept. 15-16, 2005 (“Conflicts of interest are an endemic institutional investor affliction. The problem is structural. For example, corporate pension fund managers are retained by plan sponsors and may find themselves acting in the best interests of the corporation rather than the beneficiaries who have entrusted their retirement savings to the plan. Similarly, trustees of public and union pension plans may seek to use their position to further political interests at the expense of beneficiaries, for example, by using beneficiary funds to engage in litigation that is politically motivated or to further "union" issues which may not bear on governance. Alternatively, institutional investors may be reluctant to sue to recover fraud-related losses where those lawsuits would be launched against other institutions with which they have a relationship. Banks that engage in proprietary trading may inappropriately support those activities using information they gather from clients in relation to trading intentions. These conflicts are increasing coming to the attention of regulators. In fact, some regulatory intervention has already occurred in the institutional investor community in the United States in relation to mutual funds. As a result of rules adopted on January 23, 2003, the SEC requires investment companies and their advisers to disclose the fund's voting policies and procedures, actual votes cast and how material conflicts of interest are dealt with.”).

[846]. For a discussion see, e.g., Symposium, The Institutional Investor's Goals for Corporate Law in the TwentyFirst Century, 25 DEL. J. CORP. L. 35-69 (2000); Henry T. C. Hu, Risk, Time, and Fiduciary Principles in Corporate Investment, 38 UCLA L. REV. 277, 287-95, 314-32, 365-66, 385-86 (1990).

[847]. For statistics and commentary see e.g., Troy A. Paredes, On the Decision to Regulate Hedge Funds: The SEC's Regulatory Philosophy, Style, and Mission, 2006 U. ILL. L. REV. 975 (2006); see also Henry T. C. Hu \& Bernard Black, The New Vote Buying: Empty Voting and Hidden (Morphable) Ownership, 79 S. CAL. L. REV. 811 (2006). On the role and incentives of arbitrageurs, see Jim Hsieh \& Ralph A. Walkling, Determinants and Implications of Arbitrage in Acquisitions (Tuck Contemporary Corporate Finance Issues III Conference Paper; Dice Center Working Paper No. 2003-14), available at http:// papers.ssrn.com/sol3/papers.cfm?abstract_id=571022. 
[848]. On the role of research analysts and the limits of rational choice in investing, see Jill E. Fisch, Regulatory Responses to Investor Irrationality: The Case of the Research Analyst, 10 LEWIS \& CLARK L. REV. 57 (2006).

[849]. For discussion of the problem of divergent time horizons, see Steven L. Schwarcz, Temporal Perspectives: Resolving the Conflict Between Current and Future Investors, 89 MINN. L. REV. 1044 (2005). For discussion of the problem of "short-termism" as it affects investing and the economy, see Lawrence E. Mitchell, The SarbanesOxley Act and the Reinvention of Corporate Governance?, 48 VILL. L. REV. 1189, 1209-10 (2003) (arguing that the pervasively short term focus of investing has infected the system of corporate management in the United States); Thomas Lee Hazen, The Short-Term/Long-Term Dichotomy and Investment Theory: Implications for Securities Market Regulation and for Corporate Law, 70 N.C. L. REV. 137 (1991) (examining the current state of American financial markets). For further discussion of behavioral finance as it affects investors' decision making, see Lawrence A. Cunningham, Behavioral Finance and Investor Governance, 59 WASH. \& LEE L. REV. 767, 792 (2002).

[850]. For example, the media reported pension fund losses attributed to Enron alone at $\$ 1.5$ billion. See Patrick McGeehan, 3 State Pension Funds Put Pressure on Wall St., N.Y. TIMES, July 2, 2002, at C1.

[851]. LUCIAN BEBCHUK \& JESSIE FRIED, PAY WITHOUT PERFORMANCE: THE UNFULFILLED PROMISE OF EXECUTIVE COMPENSATION (First Harvard University Press 2004).

[852]. Cox, 879 A.2d at 617.

[853]. Id.

[854]. See Pure, 808 A.2d at 436.

[855]. See Leo E. Strine, Jr. The Inescapably Empirical Foundation of the Common Law of Corporations, 27 DEL. J. CORP. L. 499, 509 (2002).

[856]. Cox, 879 A.2d at 646. This Article contends that Entire Fairness review in freezeouts is important to maintaining the integrity of corporate fiduciary law and strong capital markets. See infra Part V.

[857]. See also id. at 643 (“....Lynch has generated perverse incentives for both defense and plaintiffs' counsel that cast doubt on the integrity of the representative litigation process”).

[858]. Id. at 621.

[859]. This is evident also where the Cox court describes the plaintiffs' lawyers as having a "food fight" over who would be lead counsel. See Cox, 879 A.2d at 609.

[860]. Id. at 647 .

[861]. The struggle for recognition of the Socio-Economics section of the American Association of Law Schools is suggestive of this relative undervaluation of sociology, which is especially acute in the area of corporate law. See, e.g., I. Richard Gershon, Teaching Federal Income Taxation Using SocioEconomics, 41 SAN. DIEGO L. REV. 201, 201 n.2 (2004) (citing Over 120 Law Teachers from 50 Member Schools Sign Petition to Form Section on Law and Socio-Economics, SECTION ON SOCIO-ECONO. NEWSL. (Ass'n of Am. Law Sch. Washington D.C.), Jan. 1997, at 4).

[862]. Rhetorical questions are used to end discussions, rather than begin them. They imply that the matter is so obvious that there can be only one intelligent viewpoint-the one that the speaker is declaring to be self-evident. 
[863]. Cox, 879 A.2d at 647.

[864]. Id.

[865]. For discussion of important concerns under the Uniform Commercial Code, see, e.g., Linda J. Rusch, Is the Saga of the Uniform Commercial Code Article 2 Revisions Over? A Brief Look at What NCCUSL Finally Approved, 6 DEL. L. REV. 41 (2003).

[866]. Cox, 879 A.2d at 646.

[867]. Pure, 808 A.2d at 434-35.

[868]. Cox, 879 A.2d at 643.

[869]. Id.

[870]. Id. at 605 .

[871]. Id.

[872]. Id. at 605, 609.

[873]. Id. at 617.

[874]. Id. at 605.

[875]. The Cox opinion does not hide its law reform agenda. Id. at 642.

[876]. Pure, 808 A.2d at 435 (arguing that the disparity between the Lynch doctrine and the standards applied to tender offer freezeouts "creates a possible incoherence in our law").

[877]. Cox, 879 A.2d at 614.

[878]. See, e.g., Smith v. Van Gorkom, 488 A.2d 858 (Del. 1985); Cinerama, Inc. v. Technicolor, Inc. 663 A.2d 1156 (Del. 1995) (sustaining Delaware Court of Chancery's determination that merger satisfied the test of entire fairness even though board failed to meet its duty of care by failing to test the market for other merger partners).

[879]. Revlon, Inc. v. MacAndrews \& Forbes Holdings, Inc., 506 A.2d. 173 (Del. 1986).

[880]. Blasius v. Atlas Indus. Inc. v. Atlas Corp., 564 A.2d 651 (Del. Ch. 1988).

[881]. SeeParamount Commc'ns, Inc. v. QVC Network, Inc., 637 A.2d 34 (Del. 1994).

[882]. See SEC Rel. No. 34-48745, 68 Fed. Reg. 64154 (Nov. 12, 2003); NYSE, INC., NYSE LISTED COMPANY MANUAL §§ 303A.01 and 303.A.05, available at http://www.nyse.com/lcm/lcm-section.htm.; NASDAQ, INC., MANUAL § 4350(c), available at. http://nasdaq.complinet.com/nasdaq/display/index.html.

[883]. Cox, 879 A.2d at 618-20. $\underline{I d}$. at 619. (“These steps are in important ways complements and not substitutes.”). 
62 Bus. Law. 775

END OF DOCUMENT 